\title{
USE OF PRECAST, PRESTRESSED CONCRETE FOR BRIDGE DECKS
}

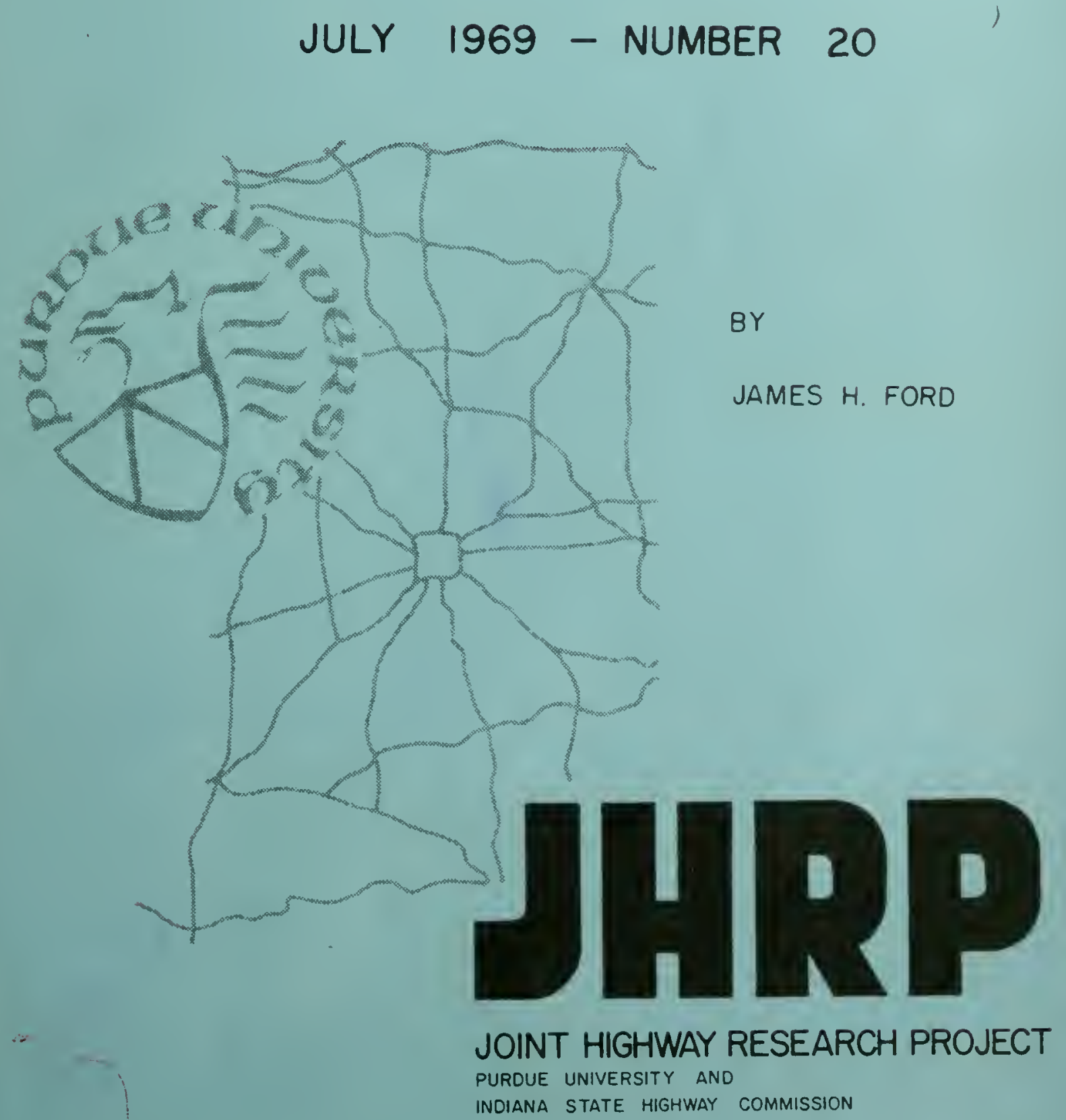



TO: J. F. McLaughlin, Director

Joint Bighray Research Broject

IROM: H. L. Michael, Associate Director Joint Bighway Research Project
July 25, 1.969

File No: 7-4-14

Project No: C-36-56N

Attached is a Progress Report on the LPR Part II research project tirled "Trecast, Prestressed Concrete for Bridge Decks". This report is titled "Use of Precast, Prestressed Concrete for Bridge Decks" and has been authored by Mr. Janes H. Ford, Graduate Asaistant in Research on our staff. Professors Martin J. Gutzwiller and $\mathrm{g}_{\mathrm{k}} \mathrm{bert}$. Lee directed the research.

The report covers the initial research on this project which has been conducted in the laboratory since the completion of the feasibility report and the approval of the laboratory phase of the project. Laboratory work is continuing but on the basis of the work completed to date and reported in this repors, a field phase of this research is being developed. A proposal wall be subnitted shortly on the construction of an experimental structural deck system as developed by this research project.

The report is submitted to the Board for acceptance as progress toward fulfillment of the objectives of this research. It will also be subaitted to the ISRC and the BRR for their review, comment and acceptance.

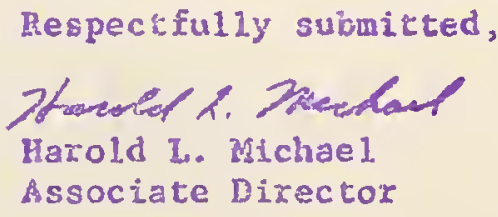

HILW/ $\mathrm{rg}$

cc:
I. L. Ashbaucher
W. ¿. Dolch
W. H. Goetz
13. I. Grecco
M. E. Harr

R. H. Earre11

J. A. Havers

V. E. Harvey

G. A. Leonards

F. B. Mendenha 1$]$

R. D. Miles
C. F. Scholer
34. B. Scott
H. T. Spencer
H. R. J. Walsh
K. B. Woods
E. J. Yoder 
USE OF RRECAST, BRESTRESSED

CONCRFTE KOR RRIDGE DECES

by

James H. Ford

Graduate Assistant in Research

Joint Highway Research Droject

File to: 7-4-14

Project Ho: C-36-56:

Brepared as Part of an Investigation

Conducted by

Jojnt Righway Research Project

Engineering Exyeriment Station'

Surdue University

in cooperation with the

Indiena State Highway Cozanisaion

and the

U.S. Department of Transportation

Federal Highway Administration

Bureau of Public Roads

The opinione, Eindings and concluslous expressed in this

publication are those of the nuthors and not necessarily those of the Bureau of Public Roads

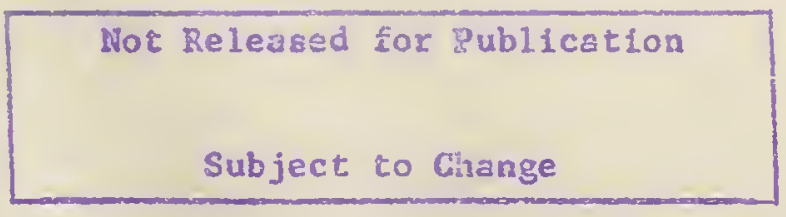

lot Reviewed By

Indfans State Highway Commission

or the

Bureau of Public Roads

Purdue University

Lafayette, Indiana

July 25,1969 
Digitized by the Internet Archive in 2011 with funding from

LYRASIS members and Sloan Foundation; Indiana Department of Transportation 


\section{ACKNOWLEDGM ENTS}

Acknowledgment is made to the members of the Joint Highway Research Project for funding the project.

Special thanks are given to M. J. Gutzwiller and R. H. Lee, major professors, for their instructive guidance. Thanks are also given to Professors C. F. Scholer and E. $\dot{O}$. Stitz for their suggestions.

The author wishes to thank W. B. Telfer, laboratory technician, and several graduate students for their help in the laboratory. 
TABLE OF CONTENTS

LIST OF TABLES. . . . . . . . . . . . . . . . . v

LIST OF FIGURES . . . . . . . . . . . . . . . . . v vII

ABSTRACT. . ...................... x

INTRODUCTION. . . . . . . . . . . . . . . . . . . I I

PRECAST, PRESTRESSED DECK SECTIONS. . . . . . . . . . . 3

General Descrlotion. . . . . . . . . . . . . 3

Selection of Tyoical Design Section. . . . . . . . . 4

Typical Deck Design Celculations............ 4

Design Parameters .............. . . 4

Moment Calculations ............. 7

Stress Analysis . . . . . . . . . . . 8

Ultimate Flexural Strength. . . . . . . . . 10

Roadway Drainage at Transfer and Handling . . . . . . 12

Slab Tie-Down System ................. 17

Anchors................. . . 17

Bolting . . . . . . . . . . . . . . 19

Spring Clip................. 21

Post-Tensioning System . . . . . . . . . . . . 23

Cable .................. . . 23

Anchorage . . . . . . . . . . . . . 23

Transverse Continuity Joint... . . . . . . . . 24

Photoelastic Joint-Shape Study. . . . . . . 25

Semicircular Joint Model ........ 26

Circular Sector Joint model. . . . . 28

Flat Key-Type Joint Model. . . . . . 28

Joint Testing with Concrete Hodels. . . . . . 38

Clrcular Sector Joint ilodel. ...... 39

Flat Joint Model ............ W W

Joint Materials. . . . . . . . . . . . . 45

DESIGN OF PRESTRESSED IABORATORY SPECIMENS. . . . . . . . 48

Design for Beam Spacing of Four-Feet . . . . . . . 49

Design for Beam Spacing of Eight-Feet. . . . . . . . 51

CONSTRUCTION OF PRESTRESSED CONCRETE ELEMENTS . . . . . . . 57

Formwork ...................... 57

Bolt Inserts................... 59 
TABLE OF CONTENTS (Continued)

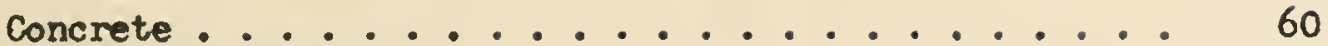

Concrete Placement .............. 64

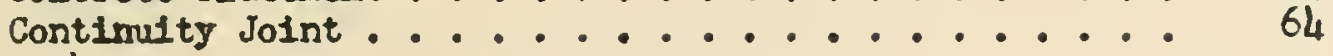

LABORATORY TESTMIG OF FUIL-SCALE DECK . . . . . . . . . . 67

Ioad Cell Design and Callbration . . . . . . . . 67

Iongltudinal Forces on Deck. . . . . . . . . . 70

Description of Test.............. 78

Sertes I................ 78

Serles II ............ 79

Serles III . . . . . . . . . . 79

Measurement of Movement. . . . . . 83

Results of SIIp Test. . . . . . . . . . 83

Static Teating of Specimens Reinforced for

4'-o" Beam spacing. .............. . . 87

Descrlption of Test ............. 87

Measurement of Loads . . . . . . . 87

Measurement of Deflection. ....... 87

Measurement of Strain. . . . . . . . 91

Sources of Error . . . . . . . . . 99

Strain Gage Application. ........ 99

Rosults ................. 100

Static Testing of Specimens Reinforced for

8'-0" Beam Spacing............... 110

Description of Test.............. 110

Resrlto................. 110

TESTING OF PRESTRESSED SPECIMENS UNDER REPEATED IOAD. . . . . 125

Repeated Ioad Test With 8'-0" Beam Spacing ....... 125

Testing Procedure ............... 125

Load Application ............ 125

Strair Measurement ........... 130

Rosults . . . . . . . . . . . . . 130

Repeated Load Test Hith 4'-6" Beam Spacing . . . . . 133

COST ANALISIS . . . . . . . . . . . . . . 136

Precast, Prestressed System. . . . . . . . . . 136

Reinforced Concrete System ............. 136

Cost Compar1son. . . . . . . . . . . . . 137

CONCLUSIONS . . . . . . . . . . . . . . . . . 139

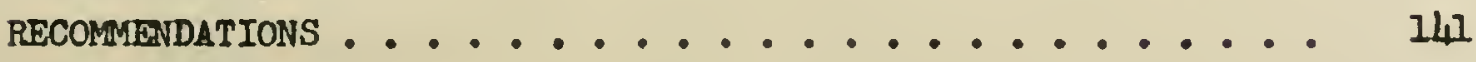

BIBLIOGRAPHT. . . . . . . . . . . . . . . . . . 145

APPENDIT A .................................... IL6

APPENDIX B . . . . . . . . . . . . . . . . . 152

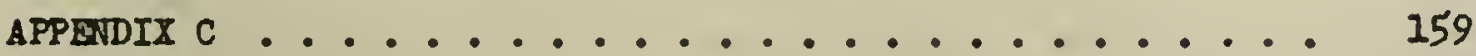


LIST OF TABLES

Table

Page

1. Measured Strains on Flat Joint Photoelastic Model ... 35

2. Principar Stress Determination on Flat Joint. ..... 36

3. Model to Prototype Scaling. . . . . . . . . 37

4. Concrete Properties of Test Specimens......... 63

5. Cable Tension Cell "A" Calibration........... 71

6. Cable Tension Cell "B" Calibration.......... 73

7. Cable Tension Cell "C" Calibration.......... 75

8. Resistance of Deck to Longitudinal Forces ........ 85

9. Load Stages During Testing of Sections Reinforced for 4'-0" Beam Spacing ..........

10. Load Stages During Testing of Sections Reinforced for 8'-0" Beam Spacing ......... 274

11. Static Bending Test, 4'-0" Beam Spacing, Deflections .................... 147

12. Strain Data, 4'-0" Beam Spacing Static Test, Top North-South Gages on Section 4-2....... 148

13. Strain Data, 4'-0" Beam Spacing Static Test, Bottom North-South Gages on Section $4-2 \ldots \ldots$

14. Strain Data, 4'-0" Beam Spacing Static Test, Top East-West Gages on Section 4-2........ 150

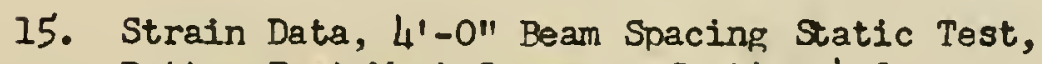
Bottom East-West Gages on Section 4-2 ....... 151

16. Deflections During Testing of Sections Reinforced

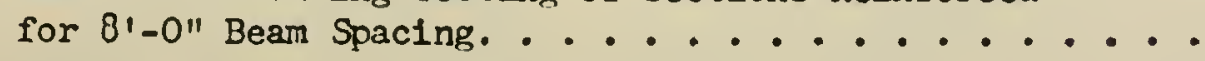

17. Strain Data, 8'-0" Beam Spacing Static Test, Top East-West Gages on Section 8-1......... 
LIST OF TABLES (Continued)

Table

Page

18. Strain Data, 8'-0" Beam Spacing Static Test,

Bottom East-West Gage on Section 8-1......... 155

19. Strain Data, 8'-0" Beam Spacing Static Test,

Top North-South Gapes on Section 8-1. ........ 156

20. Strain Data, 8'-0" Beam Spacing Static Test,

Bottom North-South Gage on Section 8-1 ....... 157

21. Strain Data, 8'-0" Beam Spacing Static Test,

Gage on Top Surface of Section 4-2......... 158

22. Strain Gage Readings, Repeated Load Test

With 8'-0" Beam Spacing............. 160

23. Strain Gage Readings, Repeated Load Test

With 4'-6" Bean Spacing .............. 161 
1. Typical Design Section............... 5

2. Typical Moment Design Section. ............ 6

3. Typical Reinforcing Pattern - 250K Grade ........ 8

4. Calculated Concrete Stresses Under Service Load. . . . . 9

5. Strain Geometry and Stress-Force Relationships at Ultimate Capacity ................ 11

6. Slab Handling, Plck-up at Quarter Points ........ I I4

7. Handlins Stresses at Pick-up Point Inmediately After Stress Transfer. ................ Il

8. Applied Torque Versus Clamping Force, 3/4" Bolt. . . . 20

9. Slab Tie-Down Arrangement. . . . . . . . . . . 22

10. Loading of Photoelastic Joint Models . . . . . . . 26

11. Principal Stress Directions on Semicircular Joint. . . . 27

12. Photoelastic Model, Semicircular Joint ......... 27

13. Principal Stress Directions on Circular Sector Jolnt . . 29

14. Photoelastic Model, Circular Sector Joint. . . .... 29

15. Principal Stress Directions on Flat Joint........ 31

16. Photoelastic Model, Flat Joint ............. 31

17. Flat Joint Model Fringe Photograph, $P=100$ lb .... 32

18. Flat Joint Model Fringe Photograph, $P=200$ Ib ..... 32

19. Flat Jo1nt Model Fringe Photograph, $P=300$ Ib ..... 33

20. Flat Joint Model Strain Gage Locations. . . . . . . 33 


\section{IIST OF FIGURES (Continued)}

FIgure

Page

21. Concrete Jolnt Testing Model ............ 40

22. Concrete Model Joint Shapes. ............ 42

23. Laboratory Joint Testing Arrangement . . . . . . . 43

24. Calculated Concrete Stresses Due to AASHO

Loading Applied to Laboratory Specimens

Reinforced for 4 '-O" Beam Spacing. . . . . . . . . .

25. Calculated Concrete Stresses Due to AASHO

Loading Applied to Laboratory Specimens

Reinforced for 8'-0" Beam Spacing. .........

26. Laboratory Model Hardware Detail . . . . . . . . 53

27. Detall A-A, Bolt Insert Arrangement. . . . . . . . 54

28. Laboratory Model Joint Detall. ............ 55

29. Iaboratory Model Strand Placement Patterns . . . . . . 56

30. Laboratory Model Iffting Loop Detail ......... 56

31. Precasting Method for Laboratory Specimons ....... 58

32. Concrete Strength Versus Time, Laboratory Sections . . . 61

33. Crack Patterns in Sections Reinforced for 4'-0" Beam Spacing................ 62

34. Templates for Dimensional Control. . . . . . . . 65

35. Post-Tensioning Arrangement in Laboratory. ....... 67

36. Cable-Tension Load Cell Detail . . . . . . . . 68

37. Cable-Tension Load Cell Circuitry. . . . . . . . 69

38. Calibration Curve, Ioad Cell A . . . . . . . . 72

39. Callbration Curve, Ioad Cell B........... 74

40. Calibration Curve, Load Cell C . . . . . . . . 76

41. Calibration Curve, $50 \mathrm{Kip} \mathrm{Ioad} \mathrm{Cell.} \mathrm{.} \mathrm{.} \mathrm{.} \mathrm{.} \mathrm{.} \mathrm{.} \mathrm{.} 77$

42. Iongltudinal SIIp Test, Bolting Arrangements $1,2,3$. . . . . . . . . . . . . . . . . 
LIST OF FIGURES (Contimued)

Figure

Page

43. Longitudinal Slip Test, Bolting Arrangements

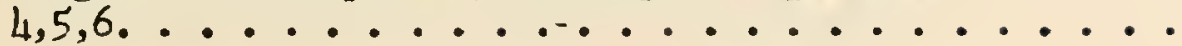

44. Testing Arrangement, Longitudinal SIip,

Series I and II. . . . . . . . . . . . . . . .

45. Testing Arrangement, Iongitudinal SIip, Series III . .

46. Horizontal Load at Slip vs. Bolting Force. . . . . . .

47. Plan View of Static Test for Sections Reinforced

for 4'-O" Center-to-Center Beam Spacing. . . . . . . .

48. Sections $A-A$ and $B-B$, Static Test with $4^{\prime}-0$ "

Beam Spacing . . . . . . . . . . . . . . . .

49. Iocations of Deflection Measurement, Static

Test, 4'-0'" Beam Spacing ................

50. Longitudinal Center Ifne Deflection, 4'-0"

Beam Spacing, Ioad Stages 1 and 2. . . . . . . . .

51. Iongitudinal Center IIne Deflection, 4'-0"

Beam Spacing, Ioad Stages 3 and 4. . . . . . . . .

52. Iongitudinal Center Iine Deflection, 4'-0"

Beam Spacing, Ioad Stages 5 and 6. ..........

53. Transverse Iine Deflection Near Load, 4'-0"

Bean Spacing, Load Stages 1 and 2. . . . . . . . .

54. Transverse Ifne Deflection Near Ioad, 4'-0"

Beam Spacing, Load Stages 3 and 4. . . . . . . . .

55. Transverse Ifne Deflection Near Load, $4^{\prime}-0^{\prime \prime}$

Beam Spacing, Ioad Stages 5 and 6. ...........

56. Strain Gage Locations on Top Surface, Static Test,

4'-0" Beam Spacing................. 101

57. Strain Gage Locations on Bottom Surface, Static

Test, 4'-0" Beam Spacing . . . . . . . . . . . 102

58. Transverse Top Surface Strains, 4'-O" Beam

Spacing, Ioad Stages $I$ and 2. ............

59. Transverse Top Surface Strains, 4'-0" Beam

Spacing, Load Stages 3 and 4............ 104 
IIST OF FIGURES (Contimed)

Figure

60. Transverse Top Surface Strains, 4'-0" Beam

Spacing, Load Stages 5 and $6 . . . . . . . . .$.

61. Transverse Bottom Surface Strains, 4'-0"

Bear Spacing, Al Ioad Stages. . . . . . . . . 106

62. Iongitudinal Strain Measured on Iongitudinal

Center Iine, 4'-0" Beam Spacing, Load Stages

1,2, and 3, Top Surface. . . . . . . . . . . .

63. Iongitudinal Strain Measured on Iongitudinal

Center Iine, 4'-On Beam Spacing, Ioad Stages

4,5, and 6, Top Surface. . . . . . . . . . 108

64. Plan View of Static Test for Sections Reinforced

for 8'-0" Center-to-Center Beam Spacing. . . . . . .

65. Sections $A-A$ and $B-B$, Static Test With 8'-O"

Beam Spacing...................

66. Locations of Deflection Measurement, Static

Test, 8'-0" Beam Spacing ................

67. Iongitudinal Center If De Deflection, 8'-0"

Beam Spacing, Ioad Stages 1 and 2. . . . . . . . .

68. Iongltudinal Center If ne Deflection, 8'-0"

Beam Spacing, Ioad Stages 3 and 4. ..........

69. Strain Gage Locations on Top Surface, Static

Test, 81-0" Beam Spactng . . . . . . . . . . . . .

70. Strain Gage Iocations on Bottom Surface, Static

Test, 8'-0" Beam Spacinf . . . . . . . . . . . . .

71. Transverse Top Surface Strains, 8'-0" Beam

Spacing, Load Stages 1 and $2 . . . . . . . . . .$.

72. Transverse Top Surface Strains, 81-0n Beam

Spacing, Ioad Stages 3 and 4

73. Transverse Bottom Surface Strains, 8:-0"

Beam Spacing, All Load Stages .............

74. Iongitudinal Strain Measured on Iongitudinal

Center Itne, 8'-0" Beam Spacing, All Ioad

Stages, Top Surface. 
LIST OF FIGURES (Contimued)

Figure

75. Testing Arrangement for Repeated Ioad Test

Wilth 8'-0" Beam Spacing. . . . . . . . . . . . . 126

76. Section B-B, Repeated Ioad Test. . . . . . . . 127

77. Section A-A, Repeated Load Test, 81-0" Beam Spacing. ....................... 128

78. Load-TIme Relationship During Repeated Ioad

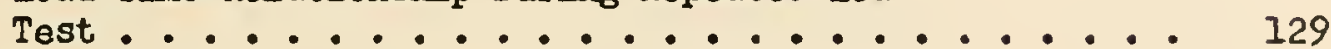

79. Strain Gage Locations for Repeated Load Test hith 8'-0" Beam Spacing. ................ 131

80. Repeated Load Test'With 8'-0" Bean Spacing ....... 132

81. Strain Gage Locations for Repeated Load Test With 4'6" Bean Spacing................ 134

82. Recommended Modification of Jolnt Detall ....... I43 
ABSTRACT

Ford, James Harvey. MSCE, Purdue University, August 1969. Use of Precast, Prestressed Concrete for Bridge Decks. Major Professora: Martin J. Gutzwlller and Robert H. Lee.

A structural deck system composed of precast and prestressed concrete sections of a size permitting over-the-highway transportation was conceived; structural design calculations conforming to the "Standard Speciflcations for Highway Bridges 1965", American Association of State Highway Officials, were made for the deck supported by steel beams spaced at the maximm anticipated prototype beam spacing. The completed deck would constst of similar precast pleces, each belng six inches deep, as long as the transverse dimension of the bridge, and of a convenient width, four feet being anticipated as a common width.

Each precast piece would be symmetrically prestressed in the direction of its longest dimension; when the pieces are in place, the prestressing is transverse on the bridge, the principal direction of bending. The several precast pieces would be post-tensioned normal to their prestress direction, in the Iongltudinal direction of the bridge. Following post-tensioning, the pieces would be tied to the supporting beams by bolting to complete the system.

The purpose of the investigation was to arrive at a structural system capable of carrying the required loads in which advanced technology in concrete $m i x$ design could be applied with the speciflc intent of Increasing deck durability. Since concrete control is more easily 
exercised in the plant than the field, a plant-produced deck is most attractive. Secondary advantages gained with a precast deck system would be quick erection times with less down-time for deck replacement and possible dead load weight savings resulting in a more economical overall bridge.

Specific areas of investigation included the slab tie-down system, the transverse continulty joint, the post-tensioning system, joint materials for waterproofing and reduction of stress concentration, and static and repeated load testing of full-scale specimens.

The investigation indicated that the system is workable and that the design procedures employed are adequate. Performance of the deck in flevare indicated that a wheel load would be nearly all carried by one prestressed section or by two adjolning sections for a wheel load near their junction. The bolting system was observed to reduce deflections and to increase resistance of the deck to horizontal motion.

Detailed designs of the prestressed sections evaluated in the laboratory are included as are the deck response data obtained for a simulated wheel load statically applied at midspan of the system for two different beam spacings.

This study constitutes the inftial work in a contimuing study of the concept which will ultimately be utilized in the construction of a monitored prototype. 


\section{INTRODOCTION}

Repairs on highway bridge decks represent a major cost item as well as an inconventence and sometimes a safety hazard to the traveling public. If deck replacement times could be measured in days rather than weeks, many benefits would be realized. The concept of using precast bridge decks is not entirely new for it has been used on several bridges as a working surface for additional paving but not as a part of the load carrying structure. It would be feasible, even in new construction, to use precast slabs; some dead load reduction in the deck could allow significant modiflcations of the structural reauiremants of a bridge. In addition, control of air entraiment and concrete placing and curing should be more easily controlled in a precasting situation.

The most imnediate projected use of the precast deck system is in replacement of existing bridge decks. The concept herein presented is to use precast and prestressed deck elements which are placed on the supporting floor beams, then post-tensioned and tied mechanically to the supporting system to achieve a deck which demonstrates satisfactory stiructural characteristics. Economy on each bridge should be realized since the deck is formed of identical pleces. In some instances, special sections might be necessitated by peculiarities of the particular floor system but the repetition of elements elsewhere in the deck should make the overall project economical. 
Rridge down-time for repatirs should be minimized since the precast elements could be stockpiled at the fobsite in the order of their use and could be placed on the bridge as soon as the original deck had been removed. Each time enough existing decik had been removed to allow placement of a precast element, the element could be placed and secured. No time would be lost in walting for the concrete to cure. The only concrete which would be cast in place would be the concrete in the approach pavement which would need to be removed to facilitate post-tensioning. For this small concrete volume, the additional cost of high early strength concrete would be justifled.

The concept of using precast prestressed concrete for bridge decks will minimize the time of replacing or indially constructing bridge decks. Plant production should result in high quality materials with good durability. Since econony must also be measured in terms of value to the regular user of the structure, the short down-time is doubly attractive, since the cost of implementing the system is comparable to the cost of present methods. 
PRECAST, PRESTRESSED DECK SECTIONS

\section{General Description}

Precast, prestressed concrete sections will form the bridge deck. The proposed sections are rectangular, four feet by six inches in crosssection and, depending on the width of the roadway, can be made in any reasonable length. The sections, being as wide as the brldge, will be placed across the beams; afterward, the sections will be post-tensioned in the longitudinal direction of the bridge to eliminate ang space between adjacent sections. Prior to the post-tensioning operation, the placing of a material in the jolnt formed by abutting sections is proposed. The joint material would have as its purpose the prevention of surface water seepage through the joint onto the beams as well as reduction of stress concentrations on the joint faces. Upon completion of the post-tensioning operation, the several pieces form a composite bridge deck.

The precasting and pretensioning operation may best be done in a concrete plant where prior experience with precast and pretenstoned beams serves as an equipment and technological base. Concrete control, including mix design, placenent, and curing, is more easily controllod in a concrete plant than is possible under field conditions. Concrete control constitutes one of the major advantages for precasting a bridge deck; it is presently necessary to replace many bridge decks because the concrete which was initially placed was of non-uniform quality and 
subsequently deteriorated, making replacement necessary.

\section{Selection of Typical Desion Section}

Prior to the design of a typical deck section, a roacway width was arbitrarily chosen. Transverse beam spacing was set at eight feet; the eight foot spacing was chosen as a probable madimm beam spacing which would be encountered. If the system may be designed for the extreme set of parameters, intermediate and lower parameters may be met with corresponding reductions in reinforcing and other related hardware; the design procedure for the large beam spacing is intended to establish an upper bound on the pretensioning force.

A 32 foot roadway width (shown in Figure 1) was not chosen as a size limit on the practical deck section, but as a practical design section for the chosen eight foot beam spacing.

Design criteria were established for the deck wherein a state of compression would be maintained over the entire section under design loading. The elimination of temsile stresses under design loading was Intended to minimize cracking due to flexure in the thin, six inch section.

Design calculations for the base design follow. Where applicable, AASHO specifications and their designation are included.

\section{Typical Deck Design Calculations}

\section{Design Parameters}

Concrete Properties
a) $\mathrm{f}_{\mathrm{c}}^{\prime}=5,000 \mathrm{psi}$
compressive strength of concrete at 28 days. AASHO 1.6 .7 

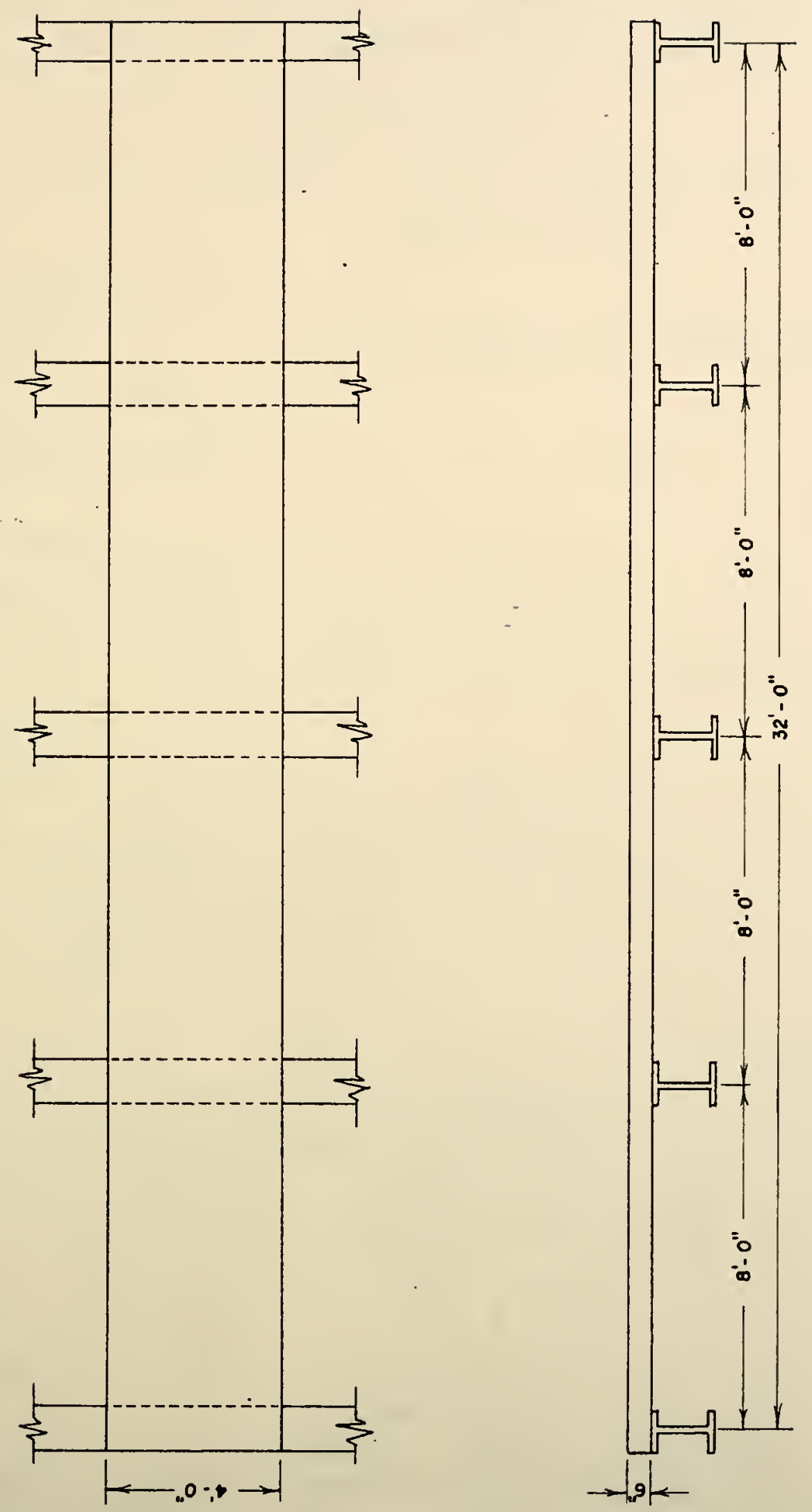

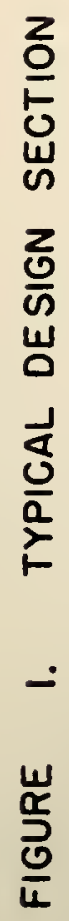


b) $f_{t}=0$ tensile stress allowed at design load

c) $f_{c i}^{\prime}=4,000$ psi compressive strength of concrete at time of initial prestress

d) $f_{c}=0.4 f_{c}^{\prime}=2,000$ psI stress at design load after losses. AASHO 1.6 .7 (B) (2)

Steel Properties
a) $I_{s}^{\prime}=250 \mathrm{ksi}$
ultimate strength of prestressing steel
b) $7 / 16 " \Phi$ strand
c) assume $20 \%$ losses

Conditions of Support

a) Wide-flange steel beams, flange width $83 / 4^{\prime \prime}$

b) Baam spacing 8'-0" c to c, continuous over f1ve supports

Loading
a) $\mathrm{HS} 20-44$
$P_{20}=16,0001 b$.
AASHO 1.3 .2 (C)
b) I - impact fraction $=30 \%$ of If
c) 6" deep concrete deck
c) 35 psf future wearing ourface

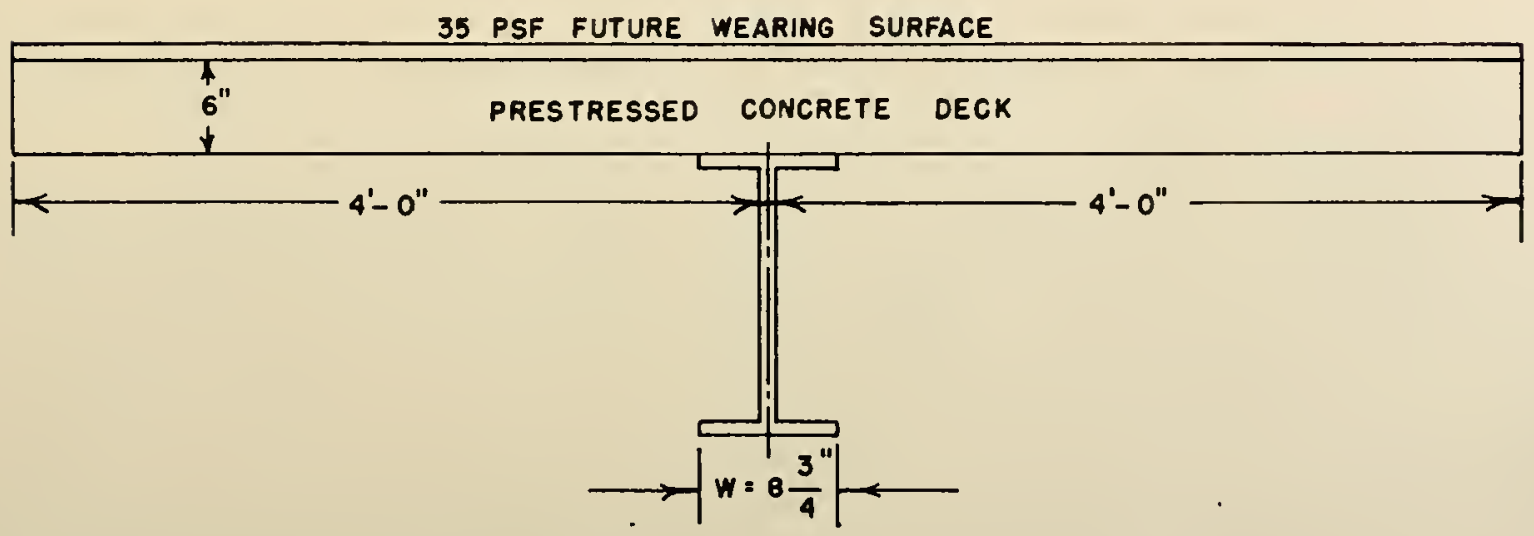

FIGURE 2. TYPICAL MOMENT DESIGN SECTION 
Moment Calculations

AASHO Iffective Span Length

According to 1.3 .2 (A) for slabs supported on steel stringers, $S=$ distance between edges of flanges plus one half of the stringer flange width.

$$
S=\left(81-0^{\prime \prime}\right)-\left(83 / 4^{\prime \prime}\right)+\left(83 / 4^{\prime \prime} / 2\right)=7.635^{\prime}
$$

\section{AASHO Live Load Moment}

By 1.3 .2 (C) for HS2O loading, the moment in foot-pounds per foot width of slab, main reinforcement perpendicular to trafflc,

$$
L I M=0.8 \frac{(S+2)}{32} \quad P_{20}=\frac{0.8(9.635) 16,000}{32}=3,850 \mathrm{ft}-1 \mathrm{~b} / \mathrm{ft}
$$

AASHO Impact Moment

$$
\Pi 1=30 \% \times(L M)=0.3(3850)=1,155 \mathrm{ft}-1 \mathrm{~b} / \mathrm{ft}
$$

Dead Load Moment

Using a value of 150 pounds per cubic foot for concrete and providing for a future 35 pounds per square foot wearing surface, untform dead load moment, for a six Inch slab becomes

$$
\mathrm{DIM}=0.8 \frac{\left(\mathrm{WS}^{2}\right)}{8}=0.1(110)(7.635)^{2}=641 \mathrm{ft}-1 \mathrm{~b} / \mathrm{ft}
$$

Total Moment

The total moment to be provided for then becomes LUM + DM + DUM which is equal to $5,646 \mathrm{ft}-\mathrm{lb} / \mathrm{ft}$ of slab. Considering a 4'-0" wide element which is six inches deep, total moment to be resisted is $4(5,646)$ $=22,584 \mathrm{ft}-\mathrm{Ib}$. 


\section{Stress Analy 818}

Section Froperties

The moment of Inertia of the concrete becomes the moment of in-

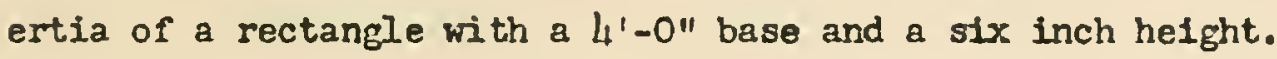

$$
I_{c}=\mathrm{bh}^{3} / 12=(4) 12(6)^{3} / 12=864 \mathrm{in}^{4}
$$

The moment of Inertia of the steel is the area-moment of the steel about the center of the section since the steel will be located In two rows, one at the top of the $s$ ab and one at the bottom of the slab, and will be uniformly distributed in those rows.

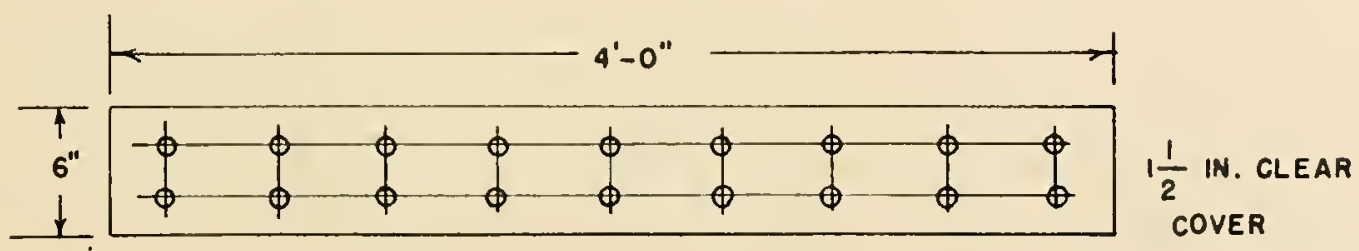

\section{FIGURE 3. TYPICAL REINFORCING PATTERN-250K GRADE STRAND}

If a $7 / 16$ inch diameter strand, ASTM A-416 grade strand is assumed, the tensioning load per strand is 18,900 pounds; after 20 percent losse8, the load is 15,110 pounds per atrand.

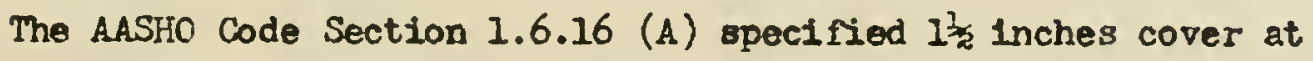
the top of the slab and one Inch cover at the bottom of the slab. Since it is desired to maintain a symetrical distribution of pretensioning force, cover will be set at $I^{\frac{1}{2}}$ inches for both top and bottom. This establiahes the steal location at 1.281 inches from the centroid of concrete area. Then, subtracting fram the steel moment of Inertia the effect of the displaced concrete;

$$
I_{s}=\left(n A_{s}-A_{c}\right) d^{2} \text { where } n 18 \text { the modular ratio of } 6 \text {. Assuming }
$$


$18-7 / 16$ inch strands,

$$
I_{s}=18(0.1089)(6-1)(1.281)^{2}=16.1 \mathrm{in}^{4}
$$

The total moment of inertia for the section is then-880.1 in $^{4}$.

The transformed area in terms of concrete area is

$$
A_{t}=A_{c}+(n-1) A_{s}=288+5(18) \cdot(.1089)=297.8 \mathrm{in}^{2} .
$$

Concrete Stresses at Working Load

The concrete stresses at service load are a combination of axial compression and bending moment. The combined stress equation is $f_{c}=\frac{-P}{A_{t}} \pm \frac{M_{C}}{I}$ where the positive $(+)$ sign indicates tension and the negative signs $(-)$ indicate compression. Solving,

$$
f_{c}=\frac{-(15,100) 18}{297.8} \pm \frac{22,588 \times 12 \times 3}{880.1}=-914 \pm 922
$$
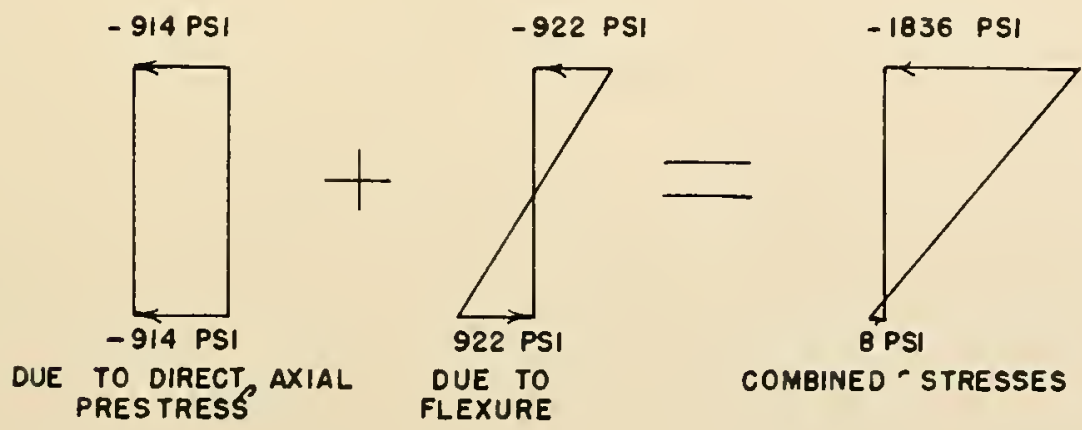

\section{FIGURE 4. CALCULATED CONCRETE STRESSES UNDER SERVICE LOAD}

Discussion of Concrete Combined Stresses

The AASHO code requirements have been met in both tension and compression. Allowable compression after losses have occurred is $0.40 \mathrm{f}_{\mathrm{c}}^{\prime}$ or 2,000 psi. Allowable tension in a precompressed tension zone 
is $3 \sqrt{\mathrm{f}_{\mathrm{c}}^{1}}$ or $212 \mathrm{psi}$. The allowable stresses are enumerated in AASHO 1.6.7 (B). Although the previously established limitation on tensile stress was to allow none, the 8 psi final tension stress is considered insigniflcant.

\section{Ultimate Flexural Strength}

Supnlied Ultimate Flexural Strength

The AASHO specified ultimate flexural strength for rectangular members is assumed as

$$
M_{u}=A_{s} f_{s u} d\left(1-0.6 \frac{p f_{s u}}{f_{c}^{\prime}}\right) ; \text { by } 1.6 .10(A) \text {. }
$$

The ultimate steel stress for a bonded member by AASHO 1.6.10 (c) is $f_{s u}=f_{s}^{\prime}\left(1-0.5 \frac{p f_{s}}{f_{c}^{\prime}}\right)$. Here, $f_{s u}=250\left(1-.5 p \frac{250}{5}\right)=$ $250-6,250(p)$. Assume here that the top row of prestressing steel lies in the compression zone at ultimate load and hence, is being unloaded. Effectively, the steel percentage, $p$, is then one half of the steel area divided by the concrete area, bd, or $9(.1089) \div 4.5(48)=$ .00454 . Then, $f_{s u}=250-6,250(0.00454)=221.6 \mathrm{ksi}$.

The ultimate flexural strength becomes

$$
\begin{aligned}
M_{u} & =9(.1089) 222(4.5)\left(1-0.6(.00454) \frac{222}{5}\right) \\
& =979(1-.121)=860 \mathrm{in}-\mathrm{K}=71,600 \mathrm{ft}-1 \mathrm{~b} .
\end{aligned}
$$

The value of $p \frac{f_{s u}}{f_{c}^{\prime}}=.201$ and the steel percentage requirement set forth in 1.6.1工 is satisfied, since the value of the expression for the reinforcement index is less than 0.3 .

It is now necessary to check the previous assumption; that the 
top row of prestressing strands lies in the compression zone is necessary. Equating compression in the concrete to tension in the bottom row of prestressing steel,

$$
T=C=A_{S} f_{\text {su }}=9(.1089) 222=217 \text { kips . }
$$

Using Whitney's stress block, 8

$$
C=a\left(0.85 f_{c}^{\prime}\right) b=a(4.25) 48=204 a
$$

$a=1.062 \mathrm{in}$. The depth of the compression zone to balance the bottom steel alone 1 s $1.062 \div .80$ (for 5,000 psi concrete) or 1.33 inches. The distance from the extreme compressive fiber to the centroid of the top row of steel is 1.719 inches.

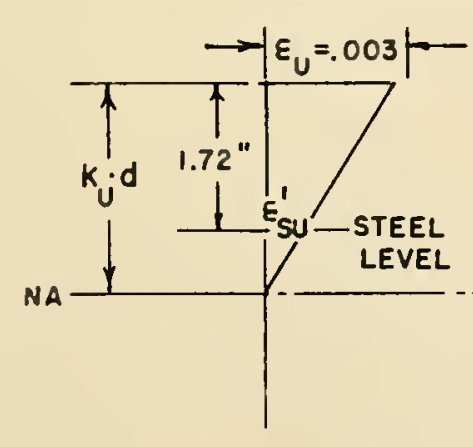

STRAIN

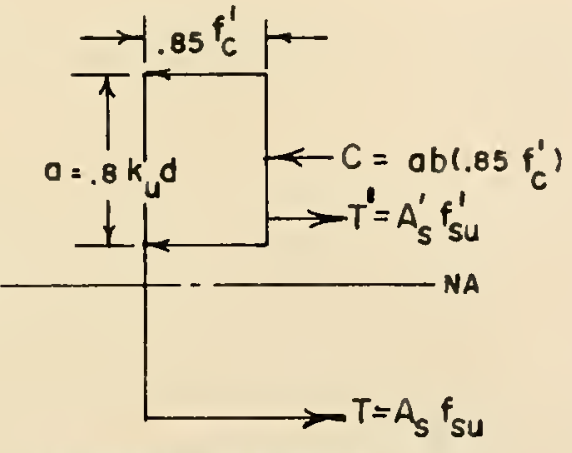

STRESS - FORCE

\section{FIGURE 5. STRAIN GEOMETRY AND STRESS-FORCE RELATION- SHIPS AT ULTIMATE CAPACITY}

Using strain compatability and internal force balance for the arrangement shown in Figure 5, assume $k_{u} d=2.072$ inches. Then

$$
\begin{aligned}
& C=338 \mathrm{k} \\
& \mathrm{T}^{\prime}=\mathrm{C}-\mathrm{T}=(338-217) \mathrm{k}=121 \mathrm{k} \\
& \mathrm{f}_{s}^{\prime}=\frac{\mathrm{T}^{\prime}}{\mathrm{A}_{s}^{\prime}}=\frac{121}{.98}=123.4 \mathrm{ksi} \\
& \varepsilon_{s}^{\prime}\left(\text { the total steel strain) }=\frac{123.4}{29 \times 10^{3}} \frac{\mathrm{ksi}}{\mathrm{ksi}}=4.25 \times 10^{-3} \frac{\mathrm{in}}{\mathrm{in}}\right. \\
& \quad \text { at ultimate }
\end{aligned}
$$


$\varepsilon_{s}\left(\right.$ the original steel strain) $=\frac{15.1 \mathrm{k}}{\left(.1089 \mathrm{in}^{2}\right) 29 \times 10^{3} \mathrm{ks} 1}$

$$
\begin{aligned}
& =4.78 \times 10^{-3} \frac{\mathrm{in}}{\mathrm{in}} \\
& \varepsilon_{\text {su }}^{\prime} \text { (the loss in steel strain) }=\varepsilon_{s}-\varepsilon_{s}^{\prime}=.000530 \frac{\mathrm{in}}{\text { in }}
\end{aligned}
$$

From the strain diagram,

$$
\varepsilon_{\text {su }}^{\prime}=\frac{\left(k_{u} d-1.72\right)(.003)}{k_{u}^{d}}=\frac{(.352) .003}{2.072}=.000510 \frac{\text { in }}{\text { in }}
$$

Therefore, it is evident that the top row of steol lies in the compression zone and is being de-tensioned at the accomplishnent of ultimate moment. The previous assumption is thereby satisfied. Required UItimate Flexural Capacity

Using the load factors found in AASHO 1.6.6, the required ultimate flexural capacity is

$$
\begin{aligned}
& 1.5 \mathrm{DLM}+2.5(\mathrm{ILM}+\mathrm{DM}) \\
& 1.5(6 \mathrm{Il})+2.5(5,005) \mathrm{ft}-1 \mathrm{~b} / \mathrm{ft} \\
& (961.5+12,512.5) \mathrm{ft}-1 \mathrm{~b} / \mathrm{ft}=13,474 \mathrm{ft}-1 \mathrm{~b} / \mathrm{ft} .
\end{aligned}
$$

For the four foot wide section under consideration, total capacity required is $53,896 \mathrm{ft}-1 \mathrm{~b}$, less than the $71,600 \mathrm{ft}-1 \mathrm{~b}$ supplied. Hence, the section is adequate with respect to ultimate flexural capacity.

\section{Stresses at Transfer and Handling}

\section{Initial Stresses}

The stresses which are initially present in the slab sections are due to axial prestressing alone. There exdst no stresses due to bending of the member since the member is fully supported by the bottom of the forms. The initial axial force is $(18,900 \times 18)$ pounds distributed over a transformed concrete area of 298 square inches. This 
results in a uniform compressive stress of 1140 pounds per square inch. AASHO 1.6.7 (B) sets a Iimit of $0.6 f_{c i}$ on this stress, or 2400 pounds per square inch in this case.

The foregoing statements assume that the strands are detensioned symmetrically about the center line and that the resulting force is arial. The largest bending moment due ta eccentricity of the strand would be the force in one cable times a lever arm of 1.28 inches. The stresses due to this eccentrically applied load are not significant for the first strand that is cut: $f_{c}= \pm \frac{M c}{I}-P / A$ $\frac{M c}{I}=\frac{(15,200 \times 1.28)}{880 \text { in }^{4}}$ in $-2 b \times 3$ in $=65.9 \mathrm{psi}(+$ or -$)$ $\frac{-P}{A}=\frac{-15,100}{298}=-50.6 \mathrm{psi}$ and the eccentric effect is nearly cancelled by the direct compressive stress, resulting in very small tension stresses.

The resultant stresses are even less critical for strands which are cut and cause bending moments due to eccentricity after at least two strands have been symmetrically released.

\section{Handling of Slab Sections}

The determination of pick-up points for the slab pieces should be made with consideration for ease of handling. Choosing two pick-up polnts along the section as convenient it will be shown that the quarter-points of the section would be acceptable plck-up points. 

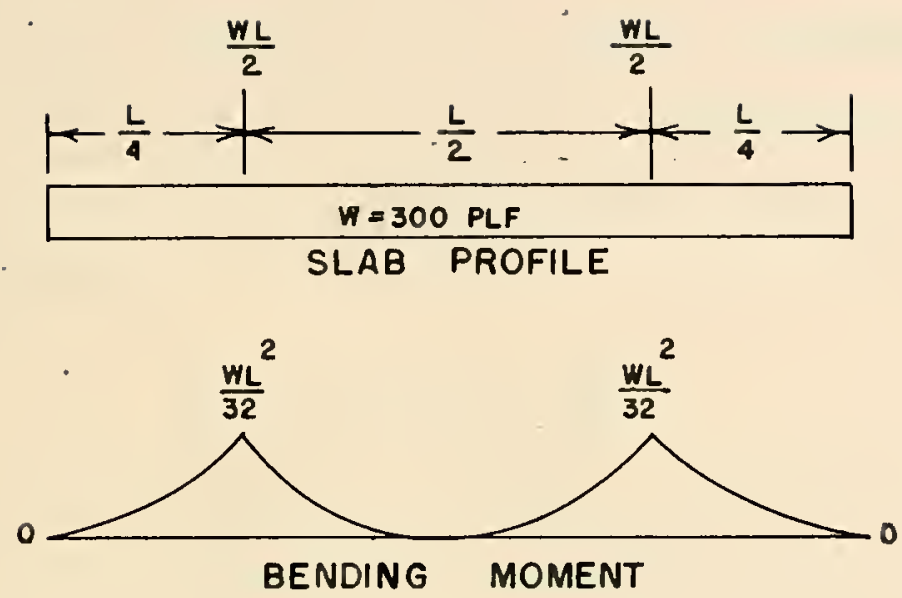

FIGURE 6. SLAB HANDLING, PICK-UP AT QUARTER POINTS

The maximum bending moment in this configuration is $\frac{W^{2}}{32}$ or $300 \cdot 32=9,600 \mathrm{ft}-1 \mathrm{~b}$. This $9,600 \mathrm{ft}-1 \mathrm{~b}$ moment is 42.5 percent of the total service moment, and would provide approximately a 57.5 percent reserve for impact due to lifting.

Assuming that pick-up is made immediately after stress transfer, the uniform axial stress due to prestressing is 1,140 pounds per square inch. Stresses due to flexure are $\pm M c / I=9,600 \times 12 \times 3 / 880$, resulting in a stress of \pm 338 psi.

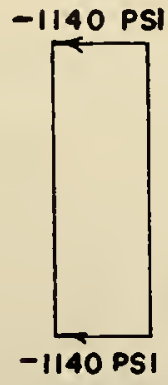

INITIAL PRESTRESS

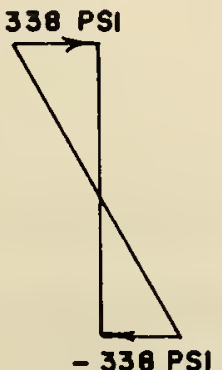

FLEXURE

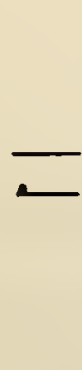

COMBINED STRESSES

FIGURE 7. HANDLING STRESSES AT PICK-UP POINT IMMEDIATELY AFTER STRESS TRANSFER 
The combined stresses due to handling immediately after transfer as shown in Flgure 7, are within the allowable stresses set by the AASHO Code. After some time and all losses, stresses due to pick-up at the quarter point would be $572 \mathrm{psi}$ on top and $1252 \mathrm{psi}$ on the bottom, both compressive.

\section{Roadway Drainage}

The single most desirable condition to be met in providing roadway drainage is simplicity in its accomplishment. Ideally, the deck section would be of unf form thickness, would be planar, and would be unformly prestressed with straight tendons.

The accomplishment of transverse drainage presents the largest problem since longitudinal drainage can easily be accomplished by providing gradient. Longitudinal drainage facilitated by camber would be tolerable but would be less desirable than drainage by gradient since the post-tensioning cable would necessarily have an arched profille.

If the prestressed deck system which is proposed was placed on a supporting system which was transversely flat and provided no natural dralnage, there are three Immediately evident ways in which transverse roadway drainage could be provided. The first and most easily accomplished method for providing transverse drainage would be the placing of an asphalt wearing surface which provides the desired crown. The typical structural design, which appeared above, provided for a future 35 psf wearing surface which could be the asphalt surface which provides the bridge crown. The disadvantages which might be experienced in the use of an asphaltic surface are: deck deterioration could take place unnoticed, causing eventual spalling of the concrete and distress 
of the steel; since asphalt does not provide a waterproof seal, there Is a possibility that water and de-icing chemicals could become trapped. Use of the asphalt wearing surface would be at the discretion of the agency in charge of the bridge and its code requirements, tempered by experience in other structures under its jurisdiction. Should the asphalt surface prove workable, it would provide an easy solution to the problem of lateral roadway drainage.

The second drainage method would consist of tilting the entire deck system to provide lateral drainage in one direction. This could be accomplished by specification in new constmaction or by releveling the supporting system on its piers when the deck system was being used in a replacement situation.

Drainage facility could be provided in another manner by casting the crown in the deck as an integral part of the roadway. The composite crown could be formed by casting the deck in an inverted position in order to provide a uniform slope to the crown (provided by the casting bed) as well as a horizontal working surface for the concrete finishers. This method would most I1kely increase the cost of the deck due to its additional forming requirement. The prestressing tendon profile could be altered to provide an axial prestressing force but at additional precasting cost. Also, the stress level in the top and bottom rows of prestressing steel might be adjusted to eliminate eccentricitg of the prestressing force. Slight variability in concrete properties from point to point along the member could negate the effort of stress level adjustment, resulting in no characteristic structural improvement from stress level adjustment. Care would nocessarily be exercised in this 
instance to ensure proper performance at ultimate capacity. In implementing this method on bridges, alignment of the crown on the adjacent sectfons would be difficult because a small misalignment, although not critical from a structural standpoint, would so evident when one vlewed the bridge longitudinally.

If it is desired to place the deck system on an existing bridge whose floor system is cambered, a natural drainage could be accomplished by stepping the bottom of the precast deck to match the camber in the floor systen. The least depth dimension, occurring at the base of each step, would be the structurally designed uniform depth, and the prestressing cables could be draped at the center of the member, thereby maintaining an axial prestressing force.

\section{Slab Tie-Down System}

The slab tie-down system which has been examined and is herein proposed consists of a $3 / 4 \times 27 / 8$ in. steel anchor, a spring steel clip, and a $3 / 4 \times 23 / 4$ in. high strength stael bolt; see Flgure 9. A similar arrangement is used by the Association of American Railroads to fasten rails to prestressed, precast concrete ties.

\section{Anchors}

The anchors recommended by The American Railway Englneering Association (AREA) are specified to be "formed from corrosion-resisting chromiun-nickel steel, meeting the requirements of ASTM specification A-167." 6 Alloy steel is also recommended by the Association of American Railroads (AAR) for any metal to be encased in concrete. The specifications also include a requirement that the anchor should be 
able to develop a vertical load of 20,000 lb or a $300 \mathrm{ft}-\mathrm{lb}$ torque without deformation of the anchor. These requirements are based on a specified concrete strength of 6,500 psi at seven days or a 28 day strength of $8,000 \mathrm{psi}$. (Two ${ }_{10} 2$ stirmups are also placed 3 in. on each side of the anchor.) There vould necessarily be a reduction of the anticipated pull-out strength of the anchors for lesser concrete strengths, or for the case of no shear reinforcement.

The anchor which was used during parts of the laboratory testing is a comercially available anchor which is formed by bending a $3 \times 2$ in. stainless steel plate to form a cylinder with a flared end, inside which threads are subsequentiy cut. This anchor was studied in the Portland Cement Association ( $P C A$ ) research laboratory with regard to pullout strength. 4 Two Identical anchors were cast in a block $10 \mathrm{in.}$ deep $18 \mathrm{in.} \mathrm{wide} \mathrm{and} 48 \mathrm{in}$. long with $24 \mathrm{in.} \mathrm{separating} \mathrm{the} \mathrm{anchors;}$ the concrete had an average cylinder strength of $6830 \mathrm{psi}$ at the time of the pullout test. Loads were monitored by a $50 \mathrm{kip} \mathrm{load} \mathrm{cell} \mathrm{and}$ were applied to a $3 / 4$ in. diameter threaded rod with a center-hole ram. The anchors $(3 / 4 \times 27 / 8$ in. uncoated $)$ were found to have an average pull-out strength of 12.8 kips and failod by tearing off the top surface of the concrete block. Similar anchors $3 / 4 \times 17 / 8$ in. (painted) were tested in the same manner and were found to have an average pull-out value of $6.6 \mathrm{kips}$, when failure by pull-out of a concrete cone around the anchor was observed.

The most desirable anchor for the precast deck is the $3 / 4 \times 27 / 8$ in. uncoated anchor. Applied torque in the bolt can be maintained at a level which will allow for an increase in load due to uplift of the 
slab without danger of damage to the concrete in the viclnity of the anchor. The anchor in place under the slab should be virtually corrosion free since it is self draining.

\section{Bolting}

The bolts specifled by the ARTA speciflcations are $3 / 4$ in. dianster, high strength steel bolts with hexagonal heads. Length is specifled as $23 / 4$ in. with a minimum engagement length of one inch but not to exceed $1 \frac{1}{2}$ inches. The speciflcations also require that the shanks of the bolts be dipped in petrolatum before engagement. The necessity for this requirement was demonstrated in the PCA testing where it was found that the force of friction between the bolt and anchor in the non-lubricated situation was large in magnitude. Achievement of the full intended tension in the bolts and the intended holding force of the fastener could not be realized with non-lubricated bolts where much of the applied torque was taken up by frlction. Performance of the lubricated bolts was as intended and predicted. For this reason, the bolts which were used in the laboratory investigation were lubricated before any torque was applied.

The applied torque versus the clamping force realized when a $3 / 4$ in. bolt is tightened is illustrated in Figure 8 . The basis for the values 1llustrated follows: "When a bolt is torqued up, the initial axial load due to the torque is approximately $F_{i}=\frac{T}{0.2 D_{0}} \cdot " 2$

$F_{i}=$ initial force

$\mathrm{T}=$ applied torque

$\mathrm{D}_{0}=$ major bolt diameter

0.2 = average factor for plain bolts 


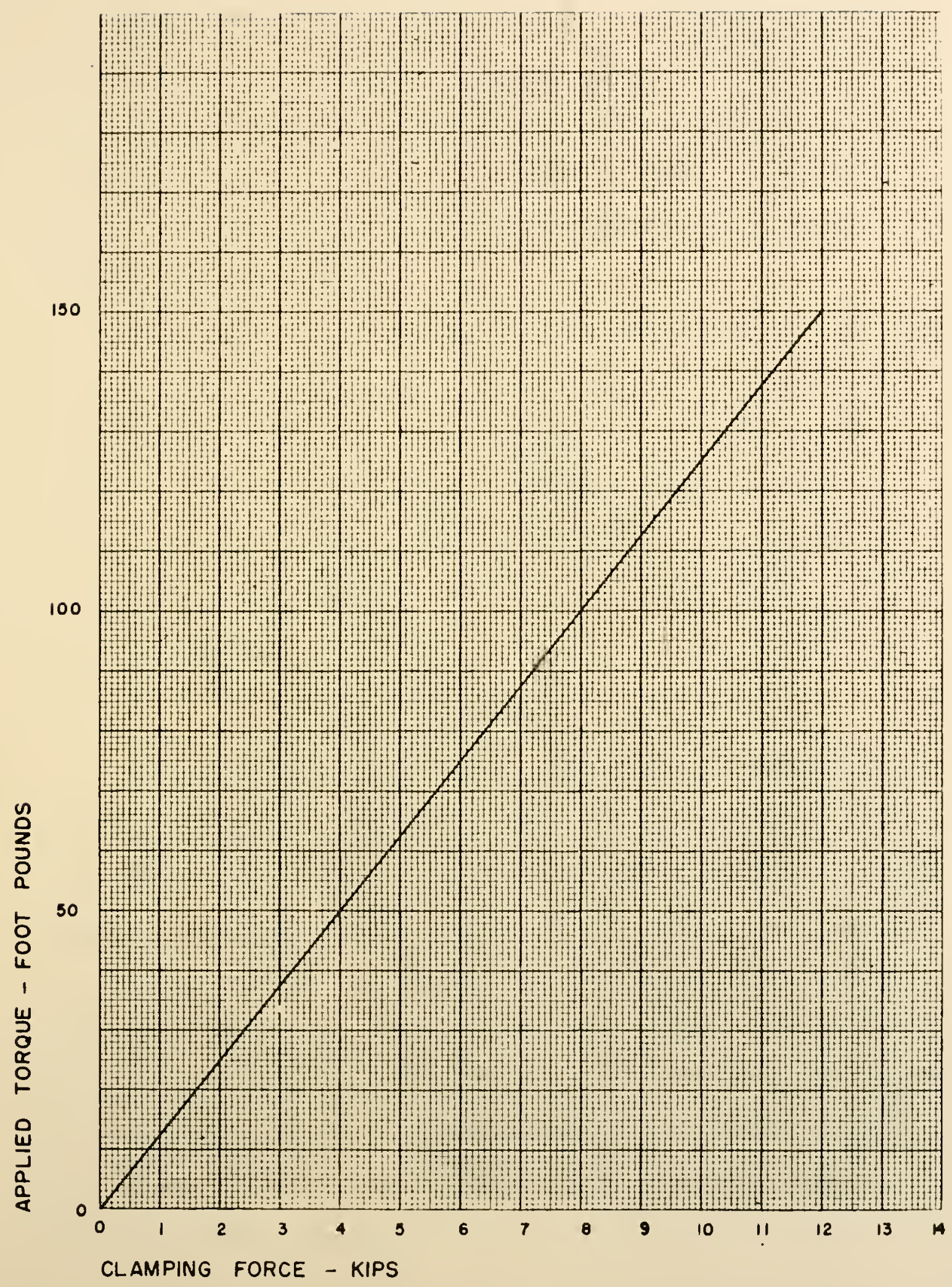

FIGURE 8. APPLIED TORQUE VERSUS CLAMPING FORCE, 3/4" BOLT 
Hence, for a $3 / 4$ inch diameter bolt, $F_{i}=\frac{T(\mathrm{ft}-\mathrm{lb}) \times 12(\mathrm{in} / \mathrm{ft})}{(0.2)(.75 \mathrm{in} .)}$ $F_{i}=80 \times T$ where $T$ is measured in ft-lbs. Faupel also indicates a maximum torque (to bring the material just below yielding) of 1,259 in.-Ib (104.9 ft-lb) for a $3 / 4$ - 10 nominal size bolt of structural steel, or 1,530 in.-1b (127.5 ft-1b) for austenitic stainless steel, the values being approximate.

The testing in the PCA laboratories indicated a loss in applied torque (at the $150 \mathrm{ft}-1 \mathrm{~b}$ level) when the bolts were subjected to repeated loading. The bolts, upon a reapplication of the initially applied torque after approximately 0.6 million cycles of loading in one case and approximately 0.1 million cycles of loading in another case where observed to maintain the desired torque value to 3 million cycles of loading. 4

\section{Spring Gip}

The spring clip, 1llustrated in Figure 9, is a commercially avallable clip wich is used by the AREA to fasten, by bolting, precast concrete ties to rafls. The clip is formed by hot-bending a strip steel bar. The suggested clip is intended by the AREA to be used with a 119CF\&I rall section, on the field side of the rail. The tongue of this clip is the largest of the standard clips, being $25 / 16 \mathrm{in}$. from center of the bolt hole to point of bearing on the tongue. The largest lap of the tongue over the beam flange to which attachment was being made would be 1 I/16 in. No evidence of clip fatigue was observed during use in the laboratory. 

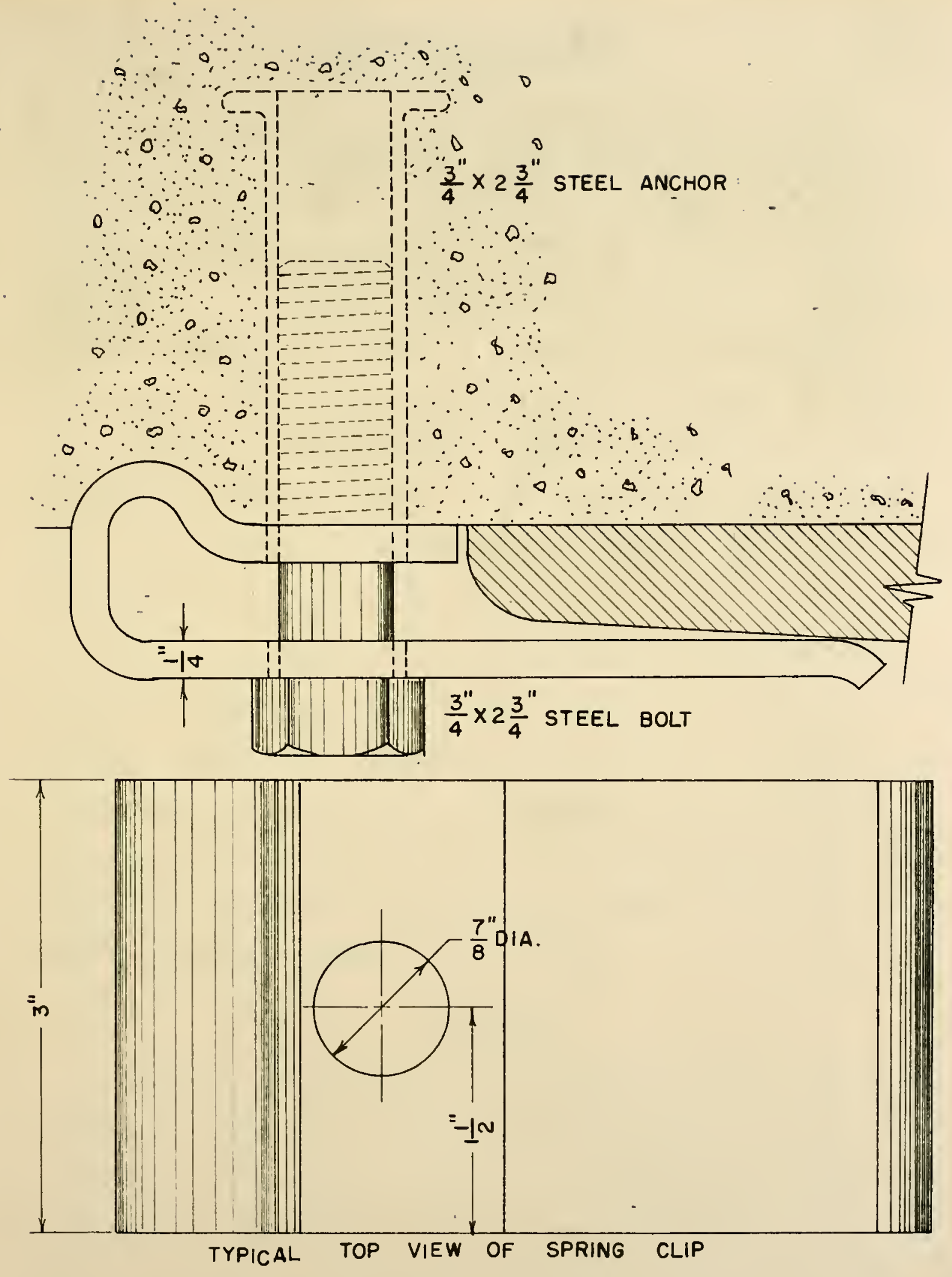

FIGURE 9. SLAB TIE-DOWN ARRANGEMENT 


\section{- Post-Tensioning system}

\section{Cable}

The post-tensioning of the several elements on a bridge deck to form a single unit will be accomplished by threading a series of cables through vold spaces which have been accurately positioned during precasting. A post-tensioning cable of one-half inch diameter is proposed in order to minimize the number of cables and the size and mmber of vold spaces. A small muber of cables would also minimize the fleld labor required to erect the system. Since it would be most desirable to maintain an unbonded cable, a coated cable which has been treated with a rust inhibitor is necessary. A cable thus formulated would not be susceptible to the corrosive action of water in the void space or to friction in the void space due to construction or repeated loading. The roid space would be placed at the center line of the slab and would be round. Size of the void space could be as much as 2 inches in diameter in the interior panels. In the special end panels containing the anchorage assemblies, the roid space should be made no larger than necessary to accommodate the strand as an greater reduction will produce anchorage zone problems upon stressing.

\section{Anchorage}

Anchorage of the cable would be by means of anchors provided in special end sections. The anchorage assemblies would be cast into the end section and the section would be placed like any other section. By precasting the end sections, fleld time for erection would be mininized. An anchor which could satisfy the requirements of the post-tensioning system proposed must be shallow and must flt between the layers of 
prestressing strand which will be in place. Special attention should be given to conventional steel reinforcing in the anchorage zone which may be recommended by the manufacturer. Special attention must also be given in the selection of a system as to the clearance requirement at the level of the slab for the post-tensioning jack; a minimm removal of approach paving is essential as it-must be replaced before traffic is allowed to return to the bridge.

\section{Transverse Continuity Joint}

The necessity of choosing a joint configuration between adjacent deck sections which would allow a flexibility of application of the deck system became immediately apparent. For the system to find more than limited use, an easily fabricated joint shape which could meet the desired post-tensioning and rotation requirements imposed by the basic design was imperative.

The purpose of the joint would basically be to transfer load between adjacent sections as well as to permit the relatively small rotations which would necessarily take place between adjacent members. These small rotations could occur due to trro dissimilar conditions; the first condition would be the requirement that the deck conform to a longitudinal deck profile as in the case of a vertical curve, and the second condition being rotations caused by moving loads which deflect the bridge floor and cause rotation between adjacent members. A contoured joint should permit these mavements and profile conformance more easily than a flat joint. Planar joints rould also have the undesirable condition of excessive bearing stresses between adjacent sections caused by line bearing during rotation or due to a longitudinal change 
in deck profile.

The problem of supplying a satịfactory transverse joint was studied in the laboratory under two quite different circumstances. A two dimensional photoelastic investigation was conducted which quite precisely indicated the principal stress directions and the stress level at selected points and permitted a prediction of the probable mode of at selocted points and permitted a pr

failure of the area adjacent to the joint due to post-tensioning, the slabs in a direction normal to the joint. At the same time, full-size concrete joint models were cast in the laboratory and were subjected to qualitative observation when rotations were imposed on the posttensioned joints by a repetitive load.

$$
\text { Photoelastic Joint-Shape Study }{ }^{*} \text { ? }
$$

The models which were selected for the photoelactic study were models whose shapes were considered to be feasible for the prototype concrete sections. The shapes of the models which were investigated are shown in Figures 11, 12, 13. For purposes of the laboratory investigation, the plastic models were made one half the size of the prototype concrete models; the dimensions of the models are shown in Figures II, 12 and 13.

The photoelastic testing, which made use of a polariscope and photography, was limited to a study of the stress distribution in adjacent sections due to a compressive force applied in the plane of the model. The compressive force corresponded to the post-tensioning force in the proposed bridge deck. It was not possible to examine the

* The photoelastic joint study was conducted by Robert J. Craig, MSCE, Purdue University. 


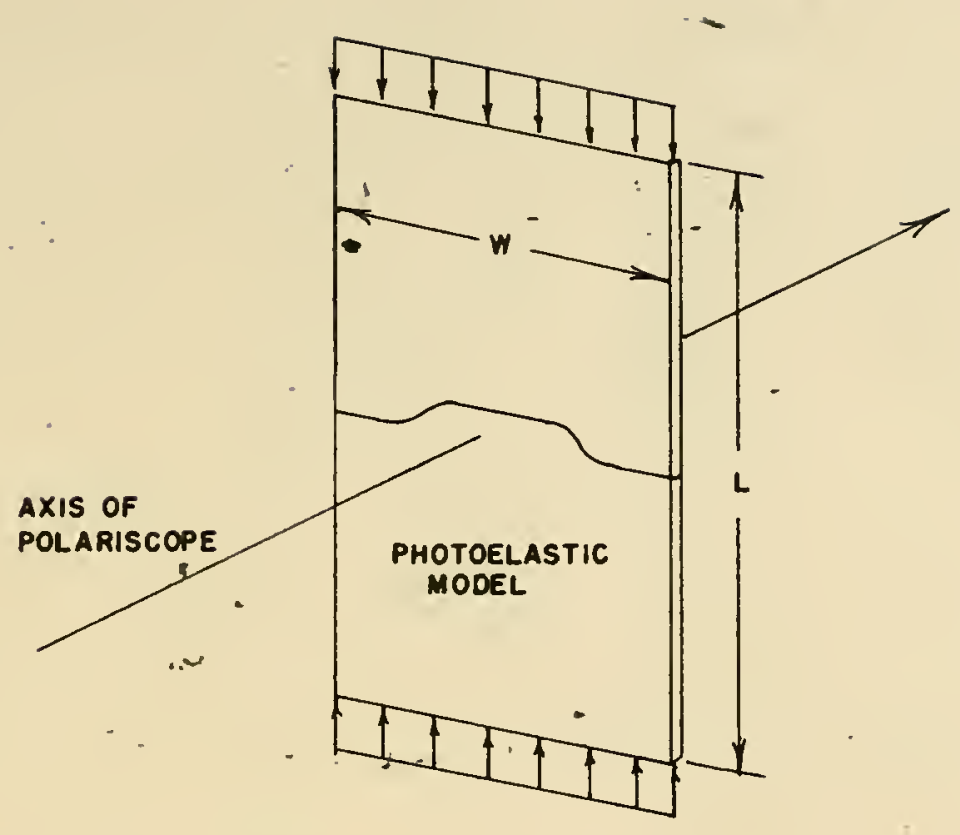

FIGURE iO. LOADING OF PHOTOELASTIC JOINT MODELS

effect of shear forces acting at the joint due to the Iimitations imposed by the loading apparatus.

The models were loaded as short columns with the length-to-width ratio of each model flxed at three-to-eight, in order that uniform stresses would develop in the model on both sides of the jolnt.

Semicircular Joint Model. The first model which was evaluated was the full semicircular section. A brittle-coating method of analysis using Stresscoat was used to determine the principal stress directions; Figure 11 indicates the direction of the principal stresses. The subscripts 1 and 2 in the flgure refer to the algebraically largest and smallest plane stresses respectively at a point, where tension is positive.

One would expect to discover tension stresses normal to the 


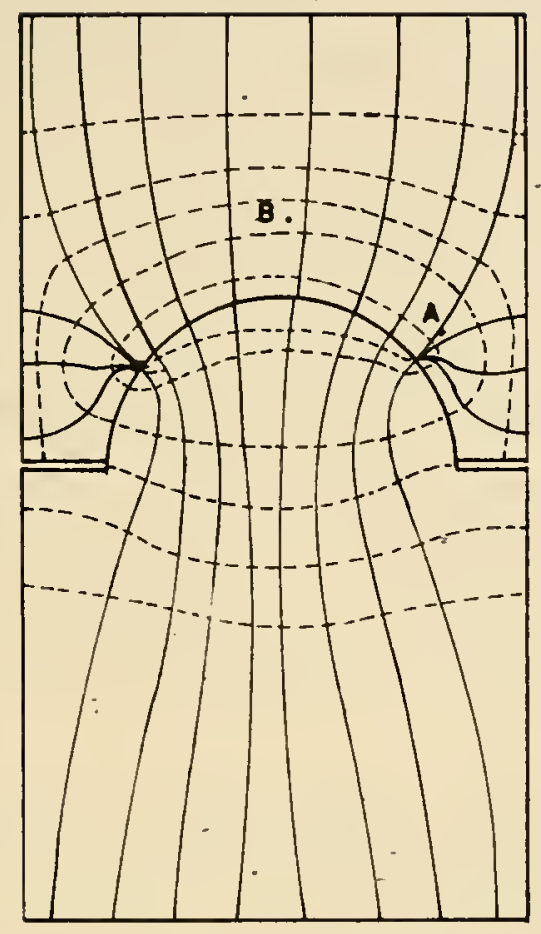

\section{STRESS TRAJECTORY DESIGNATION}

$\cdots$
$\cdots$

FIGURE II. PRINCIPAL STRESS DIRECTIONS ON SEMICIRCULAR JOINT.
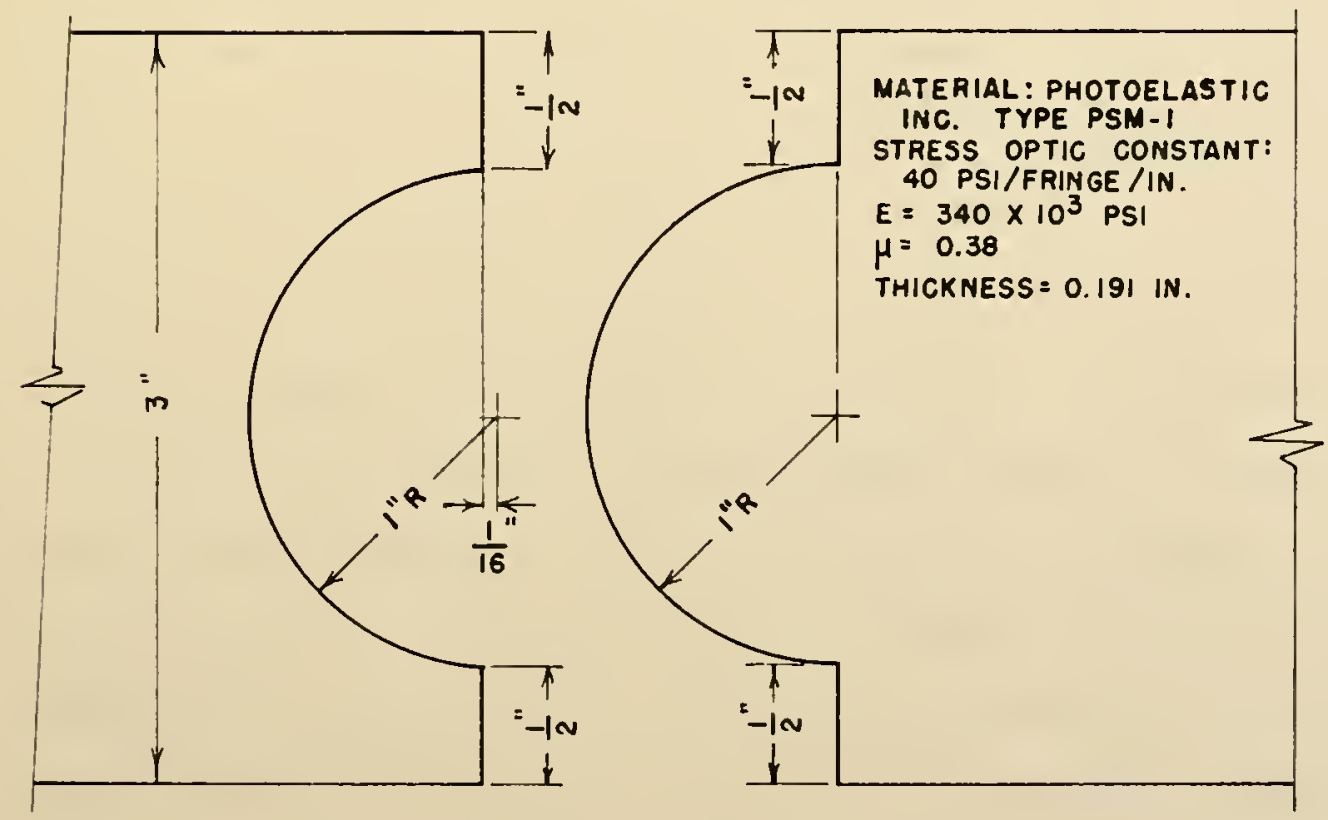

FIGURE 12. PHOTOELASTIC MODEL, SEMICIRCULAR JOINT 
stresses labeled $\sigma_{2}$, and tensile stresses of 144 psi at 30 degrees to the horizontal (joint under 100 pound load) were determined in the Vicinity of point A in Figure 11. With an increase in the compressive load on the model, the tensile forces correspondingly increased; this indlcated that in the concrete prototype, which is relatively woak in tenstion, the corners on the concave side of the joint would be expected to develop tension cracks and eventual spalling. The stress trajectories Indicated a concentration of load at the head of the semicircle which would also be an undesirable likelihood in the concrete prototype.

Circular Sector Joint Model. The circular-sector model was loaded in the same manner as the semicircular model. The principal stress directions were similar to those of the semicircular model discussed above and the existence of tensile stresses in similar locations on both models was found. The tensile stress on the concave side of the joint in the vicinity of point A (In Figure II) on the circular sector was of smaller magnitude at the same compressive load than in the semicircular joint. With the largest tensile stresses on the section tending to fracture the comers on the concave side of the joint, a secondary failure would be predicted at the center of the section since the tensile stresses at that location are of the next most critical magnitude. (point B of Flgure 11) Although the circularsector joint indicated lower stresses at similar load levels than the semicircular joint, the corner-oplitting possibility in a concrete prototype led to dismissal of the section from further consideration. Flat Key-Type Joint Model. The flat joint was found to distribute the stresses at the joint most uniformly. The stress 


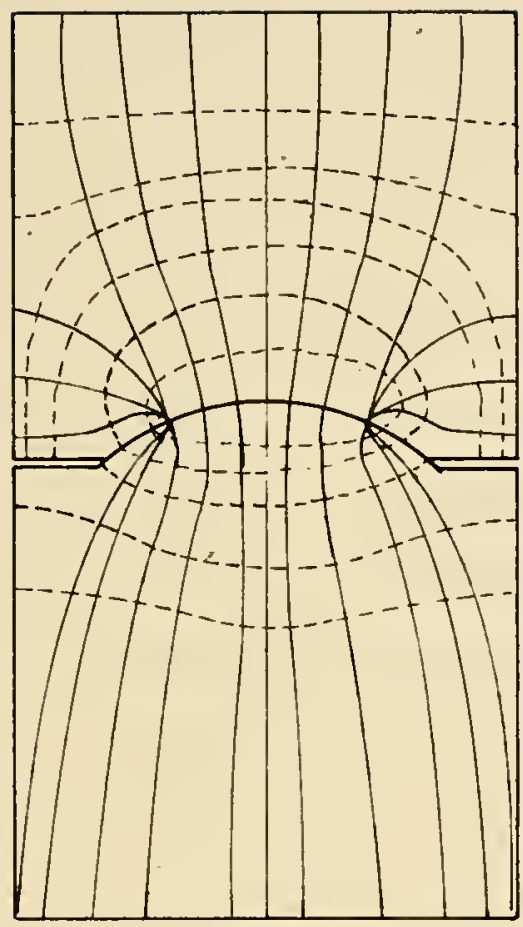

\section{STRESS TRAJECTORY \\ DESIGNATION}

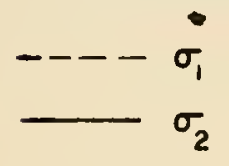

FIGURE 13. PRINCIPAL STRESS DIRECTIONS ON CIRCULAR SECTOR JOINT.

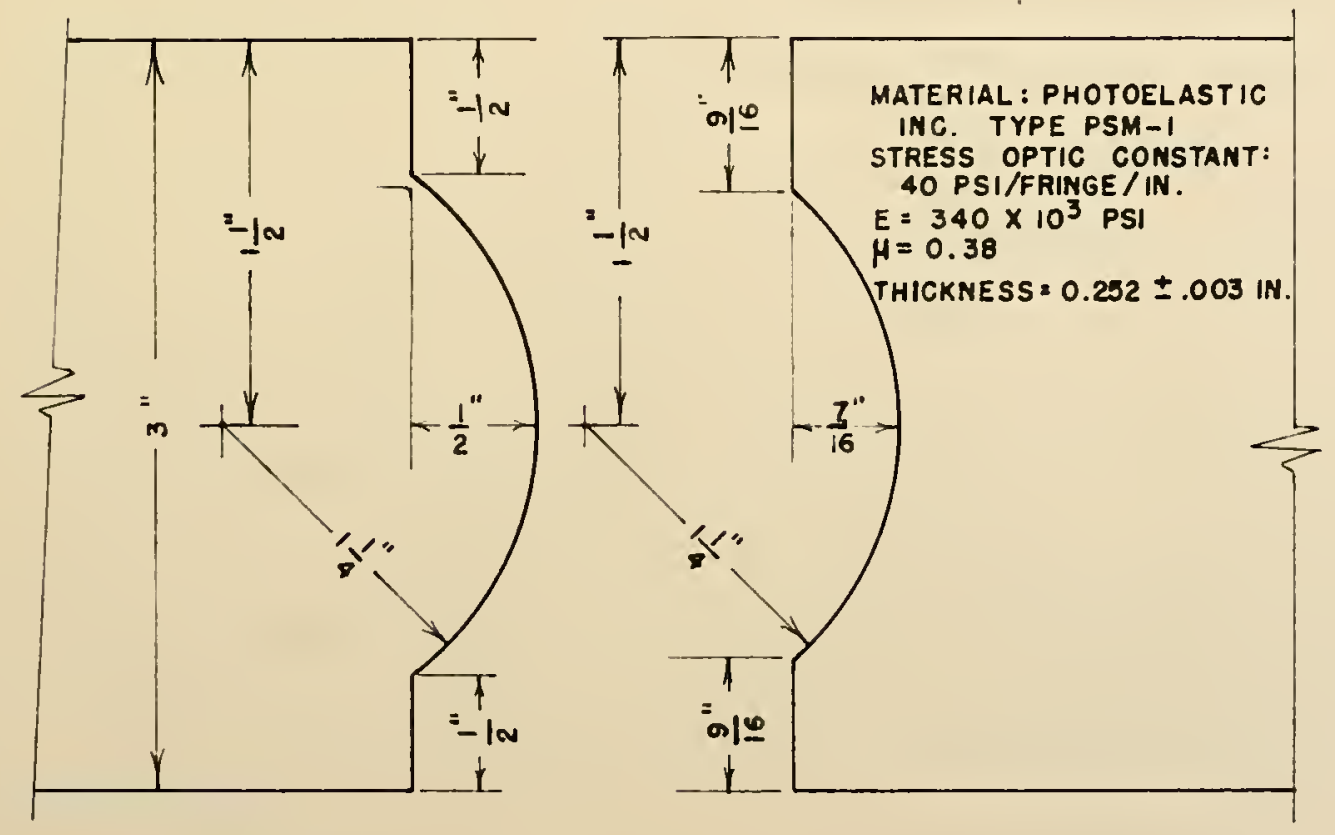

FIGURE 14. PHOTOELASTIC MODEL, CIRCULAR SECTOR JOINT 
trajectories shown in Flgure 15 were observed to become more uniform nearer the joint than was the case with the other models.

The flat joint displayed the most desirable characteristics of the three models for application to a concrete section; the flat. joint, upon evaluation, showed tensile stresses at only one point, and these tensile stresses would not be detrimental to the performance of the system because of their small magnitude. Since this joint was selected for use, an evaluation of its performance as determined using photoelasticity and electrical resistance strain gages is presented.

Evaluation of Photoelastic Data for Flat-Joint Model. The photoelastic model, shown in Figure 16, was loaded in compression in the field of a polarlscope and photographs of the resulting fringe ratterns were made. The photographs are includéd as Figures 17, 18, and 19.

The evaluation of the data thus obtained was made using the theory of photoelasticity. ${ }^{1}$ The stress optic law in two dimensions at normal incidence can be applied to the fringe photographs. The numbers on the fringe photographs indicate the fringe order at the point indicated, or the relative retardation at the point where one cycle of retardation is equal to $2 \pi$. The fringe order, $N$, is related to the principal stress difference, $\left(\sigma_{1}-\sigma_{2}\right)$, at the point in question by the relation $\left(\sigma_{1}-\sigma_{2}\right)=\frac{\mathrm{Nf} \sigma}{\mathrm{h}}$ where "f $\sigma$ " is the material fringe value and " $\mathrm{h}$ " is the model thickness. The stress " $\mathrm{O}_{1}$ " is the algebraically largest stress of the principal stresses $\sigma_{1}$ and $\sigma_{2}$, where tension is of positive sign.

For the model used (Figure 16), $\left(\sigma_{1}-\pi_{2}\right)=158.9 \mathrm{~N}$. The points 


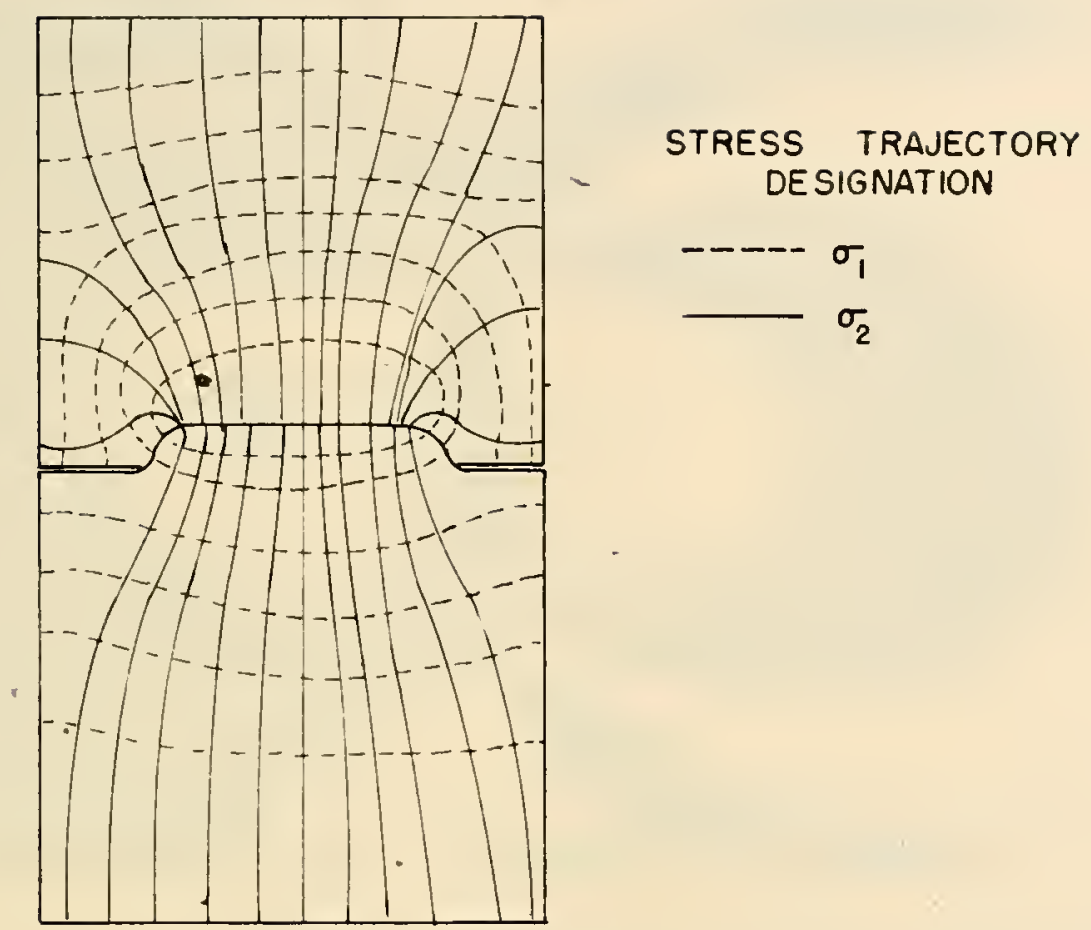

FIGURE 15. PRINCIPAL STRESS DIRECTIONS ON FLAT JOINT
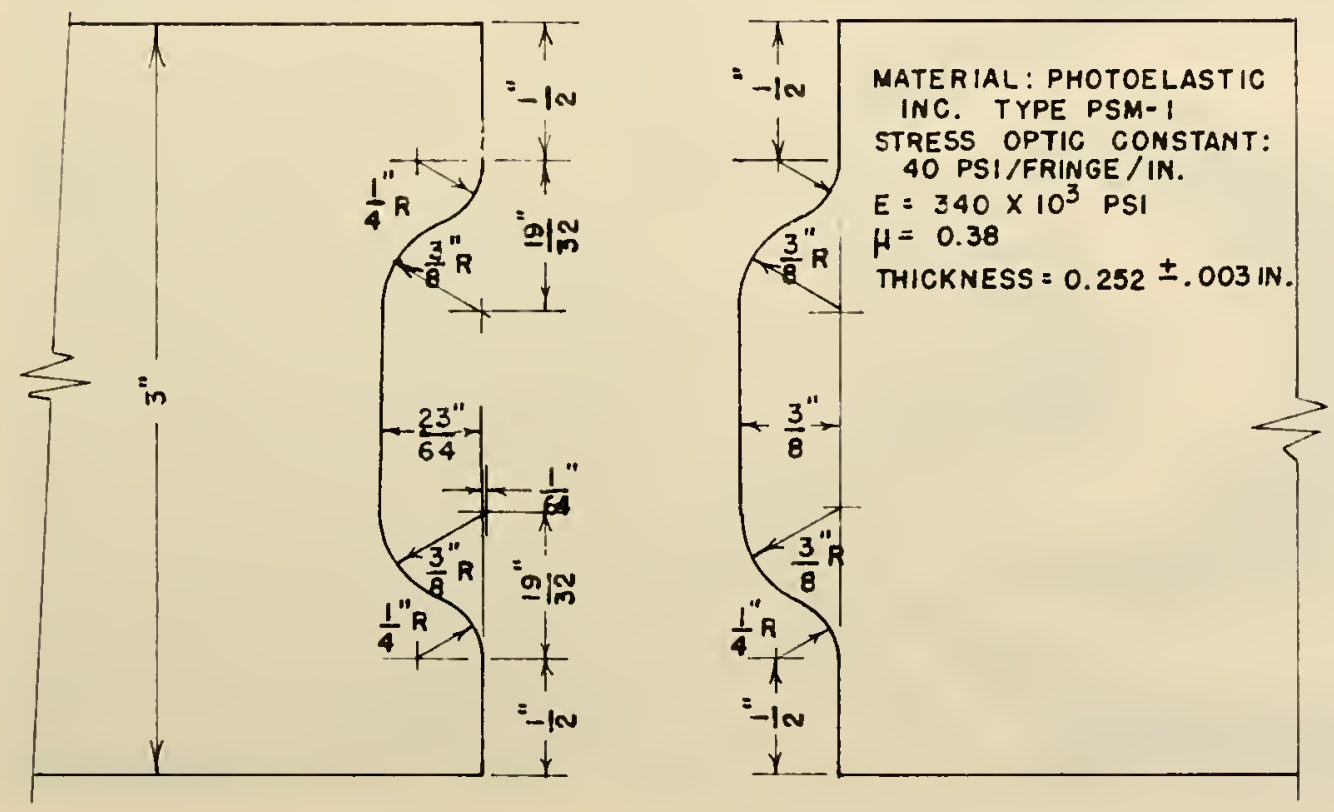

FIGURE 16. PHOTOELASTIC MODEL, FLAT JOINT 


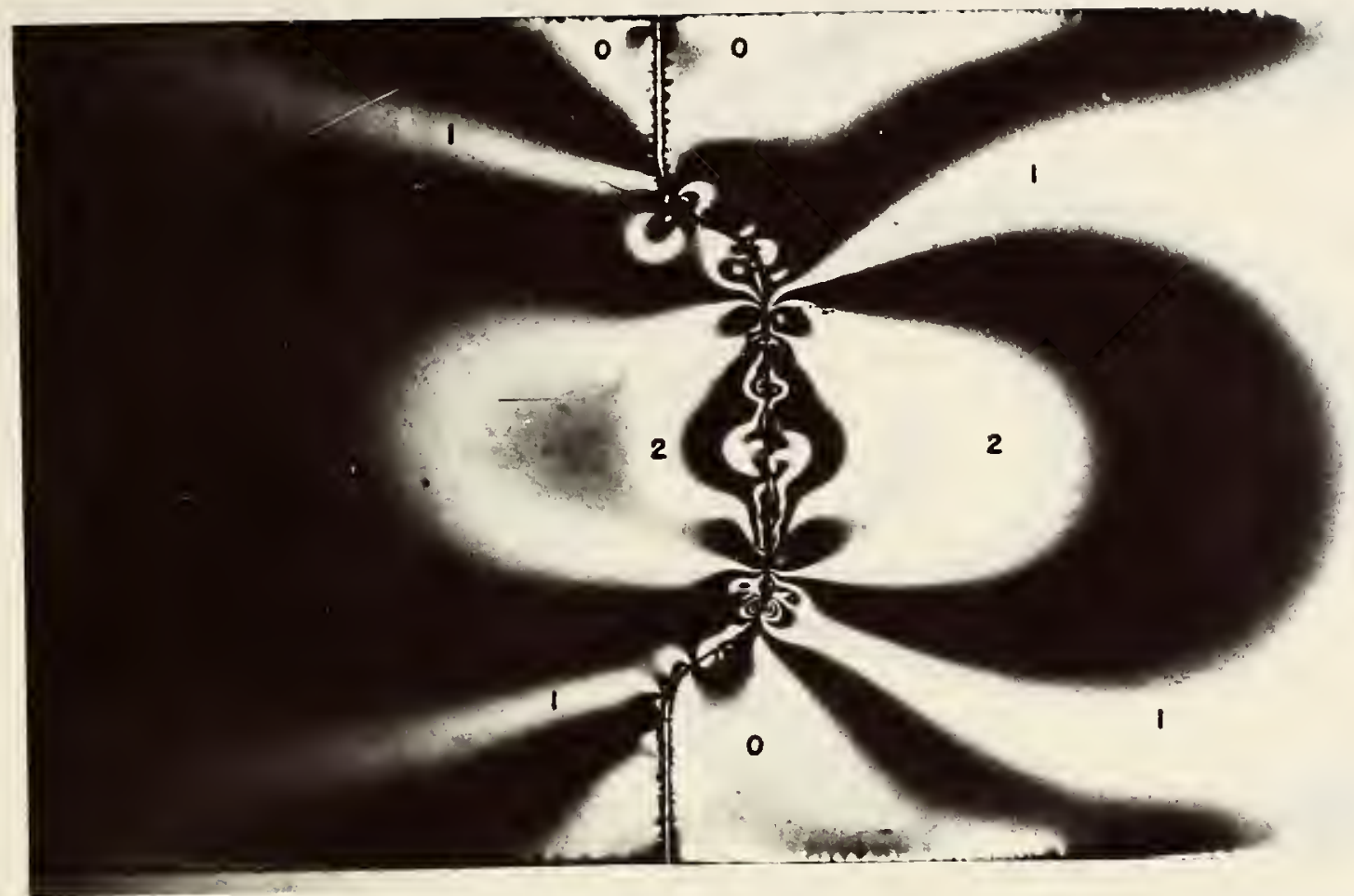

FIGURE 17. FLAT JOINT MODEL FRINGE PHOTOGRAPH , $P=100$ LB

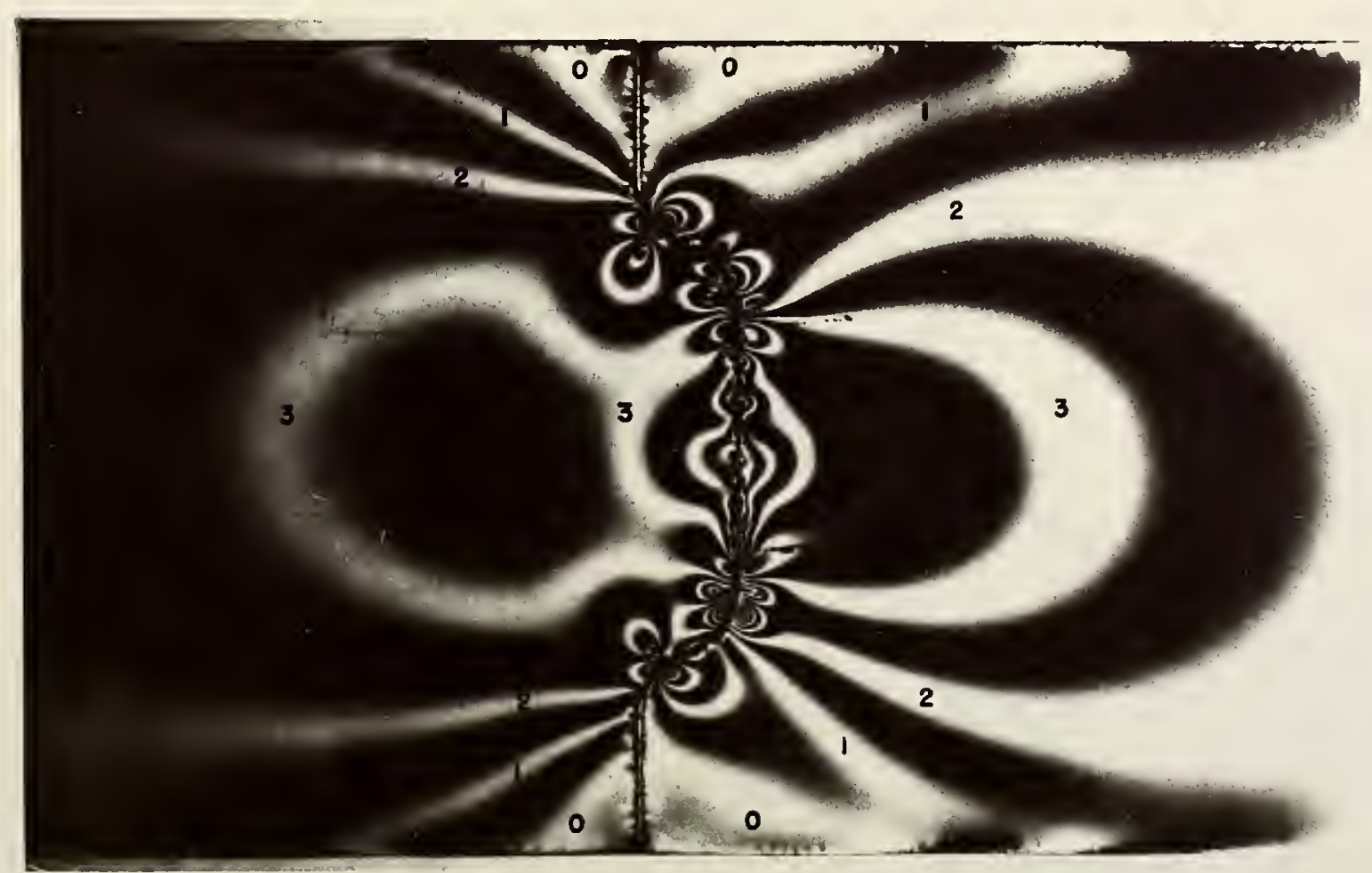

FIGURE 18. FLAT JOINT MODEL FRINGE PHOTOGRAPH, $P=200$ LB 


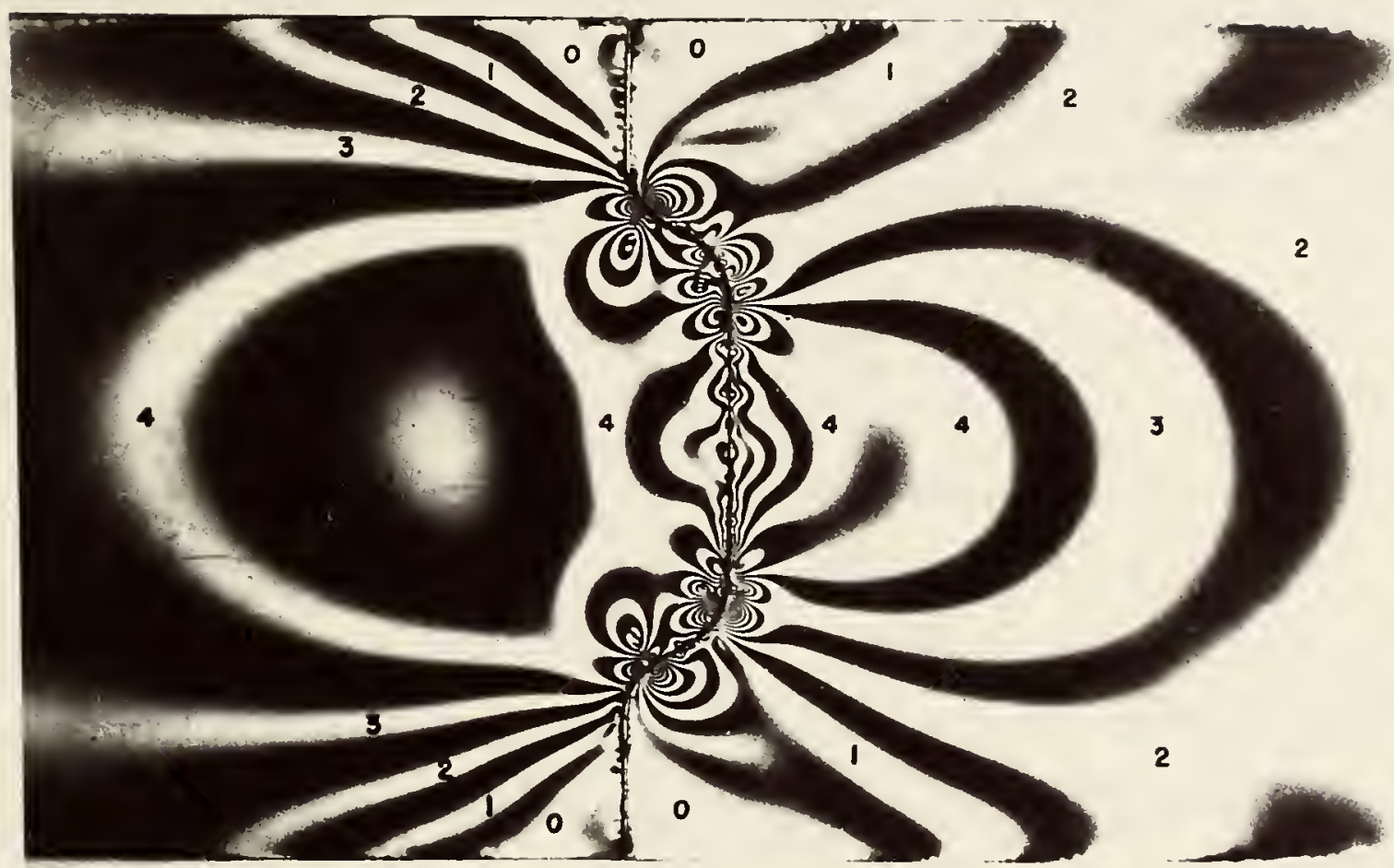

FIGURE 19. FLAT JOINT MODEL FRINGE PHOTOGRAPH, $P=300$ LB

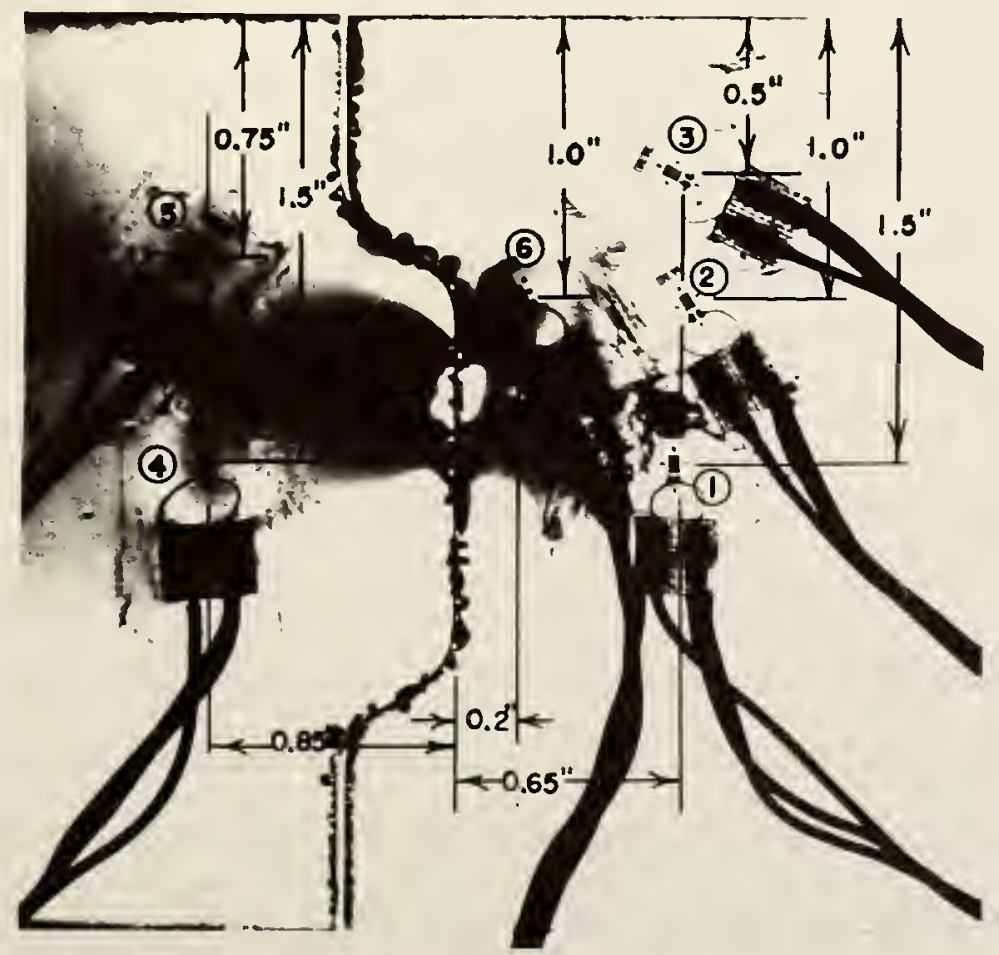

FIGURE 20. FLAT JOINT MODEL STRAIN GAGE LOCATIONS 
which were studied are shown in Figure 20. In order to separate principal stresses, strain gages were mounted at each point to be examined in the direction of the prevlously determined stress trajectory, $\sigma_{1}$ in Figure 15.

The stress trajectories were determined by a photographic method, ${ }^{3}$ based on the fact that a grid mounted at 45 degrees to the polarizer axi in a crossed plane polariscope will be visible in the light areas of a stressed-model image and the direction of the grid will indicate the direction of the principal stresses. A multiple exposure photograph, one image taken each time the arialyzer, grid; and polarizer are rotated in the same direction through 90 degrees gives a complete stress trafectory picture of the stressed model.

- Theory for Data Reduction. Trom the theory of photoelasticity, the equation relating the fringe order at a point in a stressed model and the principal stress difference at that point is known as $\left(\sigma_{1}-\sigma_{2}\right)$ $=\frac{N f \sigma}{h}$. From elasticity, the relationship between stress and strain is known as $\varepsilon_{1}=\frac{l}{E}\left(\sigma_{1}-\nu \tau_{2}\right)$. The principal stress difference is known from the fringe photographs, and the strain at selected points can be determined with electrical resistance strain gages. The strain $\varepsilon_{1}$ corresponds to the stress $J_{1}$. Solving the relationships above for $\sigma_{2}$, one finds that $\sigma_{2}(I-v)=E \varepsilon_{1}-\frac{N f \sigma}{h} ; \sigma_{2}$ can now be found directly as all quantities on the right-hand side of the equation are constant or are known from measurement. Strain gage data are presented in Table 1 and the photoelastic data are presented in Table 2. The fringe orders indicated in Table 2 are the result of graphical interpolation to arrive at the fractional fringe order. 
Table 1. Measured Strains on Flat Joint Photoelastic Model

\begin{tabular}{|c|c|c|c|c|c|c|}
\hline Load (Ib) & $\bar{I}$ & $\frac{P O}{2}$ & on $\frac{F}{3}$ & $\frac{\text { Joint }}{4}$ & $\frac{\mathrm{del}}{5}$ & 6 \\
\hline 0 & 0 & 0 & 0 & 0 & 0 & -0 \\
\hline 100 & 325 & 200 & -180 & 220 & 135 & 45 \\
\hline $200^{\circ}$ & 629 & 470 & -300 & 475 & 305 & 230 \\
\hline 300 & 1055 & 595 & -500 & 700 & & 400 \\
\hline
\end{tabular}

Strain is measured in micro-inches per inch (tension positive)

Scaling Model to Prototype Stresses. I In any two dimensionally stressed body, the stress at a point in the body 13 related to the applied load by the relationship $\sigma=\frac{P}{b h}$ where $\sigma$ is the stress, $P$ is the applied load and $b$ and $h$ are a length dimension and thickness respectirely. In dimensionless terms this becomes $I=\frac{\sigma b h}{P}$. Using the subscripts $p$ and $m$ to represent the model and prototype respectively, dimensionless (and equal) quantities may be written for each 1tem. Equating the two expressions, $\frac{\sigma_{m} m^{h}}{P_{m}}=\frac{\sigma_{p} p^{h} p}{P_{p}}$. Solving this for the prototype stress, $\sigma_{p}=\sigma_{m} \frac{b_{m} h_{m}}{b_{p} h_{p}} \frac{P_{p}}{P}$.

Table 3 demonstrates the application of this equation to the principal stresses $\sigma_{1}$ and $\sigma_{2}$ where the prototype is twice the size of the model. Assuming the applied loads and the thickness of section were the same, $\sigma_{p}=\frac{\sigma_{m}}{2}$. Direct stress on the gross section would be halred by applying the same force to the prototype as to the model.

Conclusions. As 1llustrated in Table 3, stresses which will be encountered in the prototype concrete deck system due to post-tensioning 
Table 2. Erincipal Stress Determination on Flat Joint

\begin{tabular}{|c|c|c|c|c|c|c|c|}
\hline Ioad & Point & N & $\begin{array}{c}\sigma_{1}-\sigma_{2} \\
(\mathrm{psi})^{2}\end{array}$ & (psi) & $\begin{array}{c}(1-v) \sigma_{2} \\
-(p s i)\end{array}$ & $\begin{array}{c}\sigma_{2} \\
-(p s i)\end{array}$ & $\frac{\sigma_{1}^{*}}{(p s i)}$ \\
\hline $\begin{array}{c}0 \\
100 \\
200 \\
300\end{array}$ & $\begin{array}{l}1 \\
1 \\
1 \\
1\end{array}$ & $\begin{array}{r}0 \\
2.05 \\
3.85 \\
4.30\end{array}$ & $\begin{array}{c}0 \\
191.5 \\
595.9 \\
683.3\end{array}$ & $\begin{array}{c}0 \\
110.5 \\
-\quad 213.9 \\
358.7\end{array}$ & $\begin{array}{c}0 \\
-81.0 \\
-382.0 \\
-324.6\end{array}$ & $\begin{array}{c}0 \\
-130.6 \\
-616.1 \\
-523.5\end{array}$ & $\begin{array}{c}0 \\
+60.9 \\
-20.2 \\
+159.8\end{array}$ \\
\hline $\begin{array}{c}0 \\
100 \\
200 \\
300\end{array}$ & $\begin{array}{l}2 \\
2 \\
2 \\
2\end{array}$ & $\begin{array}{c}0 \\
1.69 \\
2.95 \\
3.33\end{array}$ & $\begin{array}{c}0 \\
268.5 \\
452.9 \\
529.1\end{array}$ & $\begin{array}{c}0 \\
68.0 \\
139.4 \\
198.9\end{array}$ & $\begin{array}{c}0 \\
-200.5 \\
-313.5 \\
-330.2\end{array}$ & $\begin{array}{c}0 \\
-323.4 \\
-505.6 \\
-532\end{array}$ & $\begin{array}{c}0 \\
-54.9 \\
-52.7 \\
-2.9\end{array}$ \\
\hline $\begin{array}{c}0 \\
100 \\
200 \\
300\end{array}$ & $\begin{array}{l}3 \\
3 \\
3 \\
3\end{array}$ & $\begin{array}{c}0 \\
1.07 \\
1.90 \\
2.05\end{array}$ & $\begin{array}{c}0 \\
170.0 \\
286.0 \\
325.7\end{array}$ & $\begin{array}{c}0 \\
-57.8 \\
-102.0 \\
-170.0\end{array}$ & $\begin{array}{c}0 \\
-227.8 \\
-388.0 \\
-495.7\end{array}$ & $\begin{array}{c}0 \\
-367.4 \\
-625.8 \\
-799.5\end{array}$ & $\begin{array}{c}0 \\
-197.4 \\
-366.8 \\
-473.8\end{array}$ \\
\hline $\begin{array}{l}0 \\
100 \\
200 \\
300\end{array}$ & $\begin{array}{l}4 \\
4 \\
4 \\
4\end{array}$ & $\begin{array}{c}0 \\
2.20 \\
3.50 \\
4.80\end{array}$ & $\begin{array}{c}0 \\
349.6 \\
556.1 \\
746.8\end{array}$ & $\begin{array}{c}0 \\
74.8 \\
158.1 \\
238.0\end{array}$ & $\begin{array}{c}0 \\
-274.8 \\
-398.0 \\
-508.0\end{array}$ & $\begin{array}{c}0 \\
-443.2 \\
-6111.9 \\
-819.3\end{array}$ & $\begin{array}{c}0 \\
-93.6 \\
-85.8 \\
-72.5\end{array}$ \\
\hline $\begin{array}{c}0 \\
100 \\
200 \\
300\end{array}$ & $\begin{array}{l}5 \\
5 \\
5 \\
5\end{array}$ & $\begin{array}{c}0 \\
1.50 \\
2.70 \\
4.10\end{array}$ & $\begin{array}{c}0 \\
238.4 \\
413.1 \\
651.5\end{array}$ & $\begin{array}{c}0 \\
45.9 \\
103.7 \\
161.5\end{array}$ & $\begin{array}{c}0 \\
-192.5 \\
-309.3 \\
-490.0\end{array}$ & $\begin{array}{c}0 \\
-310.5 \\
-498.9 \\
-790.3\end{array}$ & $\begin{array}{c}0 \\
-72.1 \\
-83.8 \\
-138.8\end{array}$ \\
\hline $\begin{array}{l}0 \\
100 \\
200 \\
300\end{array}$ & $\begin{array}{l}6 \\
6 \\
6 \\
6\end{array}$ & $\begin{array}{c}0 \\
1.65 \\
2.75 \\
3.25\end{array}$ & $\begin{array}{c}0 \\
246.3 \\
421.1 \\
516.4\end{array}$ & $\begin{array}{c}0 \\
15.3 \\
78.2 \\
136.0\end{array}$ & $\begin{array}{c}0 \\
-231.0 \\
-342.9 \\
-380.4\end{array}$ & $\begin{array}{c}0 \\
-372.6 \\
-553.1 \\
-613.5\end{array}$ & $\begin{array}{c}0 \\
-126.3 \\
-132.0 \\
-97.1\end{array}$ \\
\hline
\end{tabular}


Table 3. Model to Prototype Scaling

\begin{tabular}{lcccc}
\hline Ioad & Point & $\begin{array}{c}\text { Prototype } \\
\sigma_{2} \\
(p s 1)\end{array}$ & $\begin{array}{c}\text { Stress } \\
\sigma_{1} \\
(\text { psi) }\end{array}$ & $\begin{array}{c}\text { Prototype } \\
\text { Gross Section } \\
\text { Stress (psi) }\end{array}$ \\
\hline 100 & 1 & -65.3 & +30.5 & -66.7 \\
200 & 1 & -313.0 & -10.1 & -133.3 \\
300 & 1 & -261.7 & +79.9 & -200 \\
100 & 2 & -161.7 & -27.4 & -66.7 \\
200 & 2 & -252.8 & -26.3 & -133.3 \\
300 & 2 & -266.0 & -1.5 & -200 \\
100 & 3 & -183.7 & -98.7 & -66.7 \\
200 & 3 & -312.9 & -183.4 & -133.3 \\
300 & 3 & -399.7 & -236.9 & -200 \\
100 & 4 & -221.6 & -46.8 & -66.7 \\
200 & 4 & -320.9 & -43.9 & -133.3 \\
300 & 4 & -409.6 & -36.2 & -200 \\
100 & 5 & -155.2 & -36.0 & -66.7 \\
200 & 5 & -249.9 & -42.9 & -133.3 \\
300 & 5 & -395.1 & -69.4 & 200 \\
100 & 6 & -136.3 & -63.1 & -66.7 \\
200 & 6 & -276.5 & -66.0 & -133.3 \\
300 & 6 & -306.7 & -48.5 & -200 \\
& & & &
\end{tabular}

(+) tension 
should not cause any problems near the joint section due to overstress in either tension or compression.

As shown in the photographs, contact is made only at the center of the deck on the flat portion of the joint; the stress distribution for an arrangement such as this would be. expected in a prototype thus fitted but not necessarily for the case of the entire joint in bearing on adjacent sections.

Joint Testing with Concrete Models

In order to examine the behavior of the concrete models, it was decided to approximate the curvature of a typical steel girder highway bridge. By approximating the curvature of a typical bridge, the same relative rotations between selected points could be achieved with an appropriately chosen model beam. In this manner, the joint rotations which were the object of the study would realistically approximate a prototype situation.

The typical bridge on which the curvature calculations were made had a beam span of 50'-0"'; the typical beam was taken as a $30 \mathrm{WF} 124$ beam. This simply supported beam was loaded with an HS 20-44 1ive loading and subsequent deflection calculations were made at $10 \mathrm{ft}$ intervals throughout the 50'-0" span. The load was located so as to produce the absolute maximum moment in the span and the deflection at this point was calculated in addition to the deflections at $10 \mathrm{ft}$ intervals. Knowing the deflections at the selected points, a deflection diagram was drawn. Since laboratory space was a linitation in the length selection of a testing beam, a beam length for testing was established at 21'-0" to provide a simply supported 20'-0" clear span. This 
beam, it was decided, should approximate the center 20'-0" of the typical bridge; this length included the point of maximum deflection. The deflection curve was then used to establlsh a desired deflection in the test bearn; with the points at ten feet on each side of the center line of the actual beam set as the end polnts of the testing beam, the deflections of the center twenty feet of the actual beam were detemined relative to the end points of that twenty feet. Knowing the required center Iine deflection of the proposed beam and the range of loads available in the laboratory, a moment of inertia was determined for the test beam. For a desired deflection of 0.175 in., an 18 WF 70 beam with an applied concentrated load of $20 \mathrm{klps}$ was selected. This beam, using the recommended American Institute of Steel constmuction elastic analysis procedure and $24 \mathrm{ksi}$ allowable bending stress, was found to bo sufficient to support a concentrated load of $51.4 \mathrm{kips}$ applied at its center line. Therefore, the range of loadings and accompanying deflections and curvatures could be extended if required.

The chosen beam should accurately represent the actual joint rotation requirement wilch would be found in a deck which would be placed on an actual bridge.

Qualitative studies of the feasibility of the proposed deck design were then begun. The purpose of the work was to verify some of the techniques which were proposed for the deck system.

Circular Sector Joint Model. The first model which was cast and tested was a model of the clrcular sector joint. The testing configuration consisted of four concrete elements with three joints. A typical specimen element shown in Flgure 21, was six inches deep, 34 inches wide, 


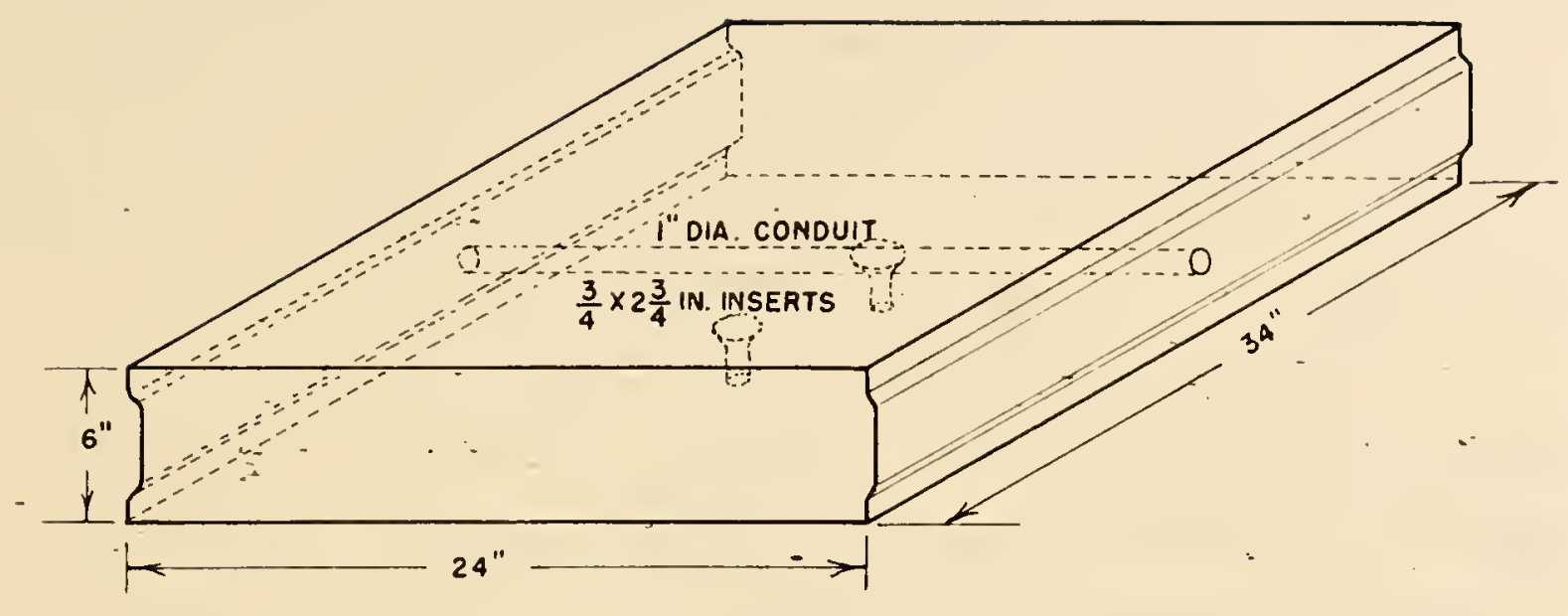

TYPICAL TEST SECTION

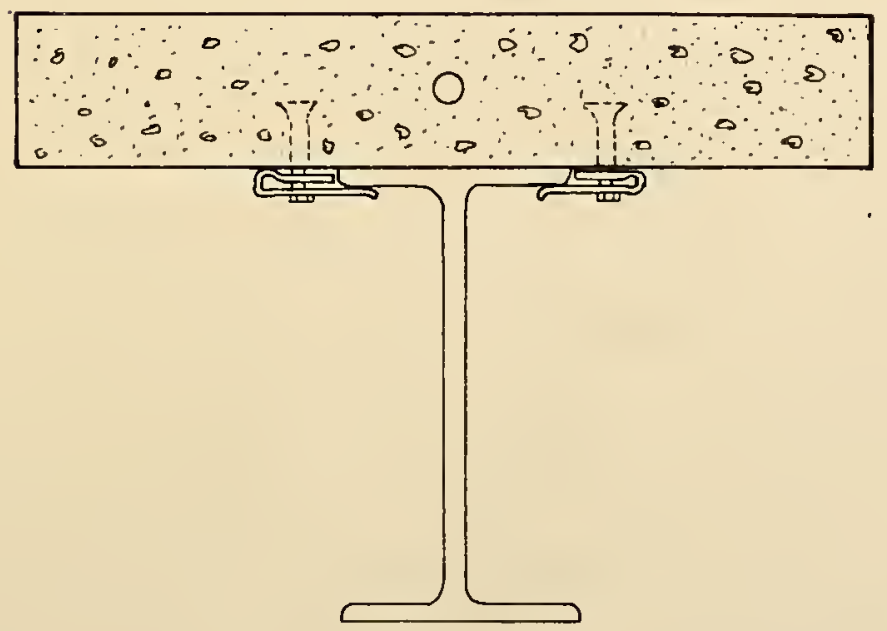

TYPICAL CROSS-SECTION AT

TIE DOWN 
and 24 inches long. No reinforcement was placed in the slab elements. A longltudinal, one inch void space was cast in the center of each specimen to accept a $3 / 8$ in. diameter post-tensioning strand. The test section was placed on a simply supported $18 \mathrm{WF} 70$ lb beam spanning 20'-0". The beam thus approximated the curvature of a prototype bridge as was previously described. The testing arrangement is shown in Pigure 23. The concrete strength at tho time of testing was approximateIy 5,300 psi. A concentrated load, applied through a nine inch diameter alumimm plate and rubber pad, was applied at the center of the beam and slab configuration at a rate of $25^{\circ} \mathrm{crm}$.

The testing arrangement allowed a variation in applied load as well as in post-tensioning force. No material was included for reduction of stress concentration at the bare concrete joint. A good fit was assured as adjacent pieces were cast back to back, sharing a common $1 / 16$ in. thick steel joint form, as shown in Flgure 22.

A repetitive load of $16 \mathrm{kip}$ maximum and $2.5 \mathrm{kip}$ minimum was applied as indicated and a post-tenstoning force of 5,000 1b พas applied to the cable to start the test. The 5,000 Ib load produced a stress on the gross concrete section of approximately 25 psi. The post-tensioning force was increased to 8,000 Ib after two hours of contimous loading, during which no adverse performance of the joint was observed. The stress on the gross section was then approximately 40 psi. Five hours after the test was begun, the applied load was increased to $20 \mathrm{kips}$, while maintaining the $8,000 \mathrm{Ib}$ post-tensioning force and the test was run to completion at eight hours. Throughout the test, loading was maintained at a rate of $250 \mathrm{cpm}$ and at the end of the test, 128,400 

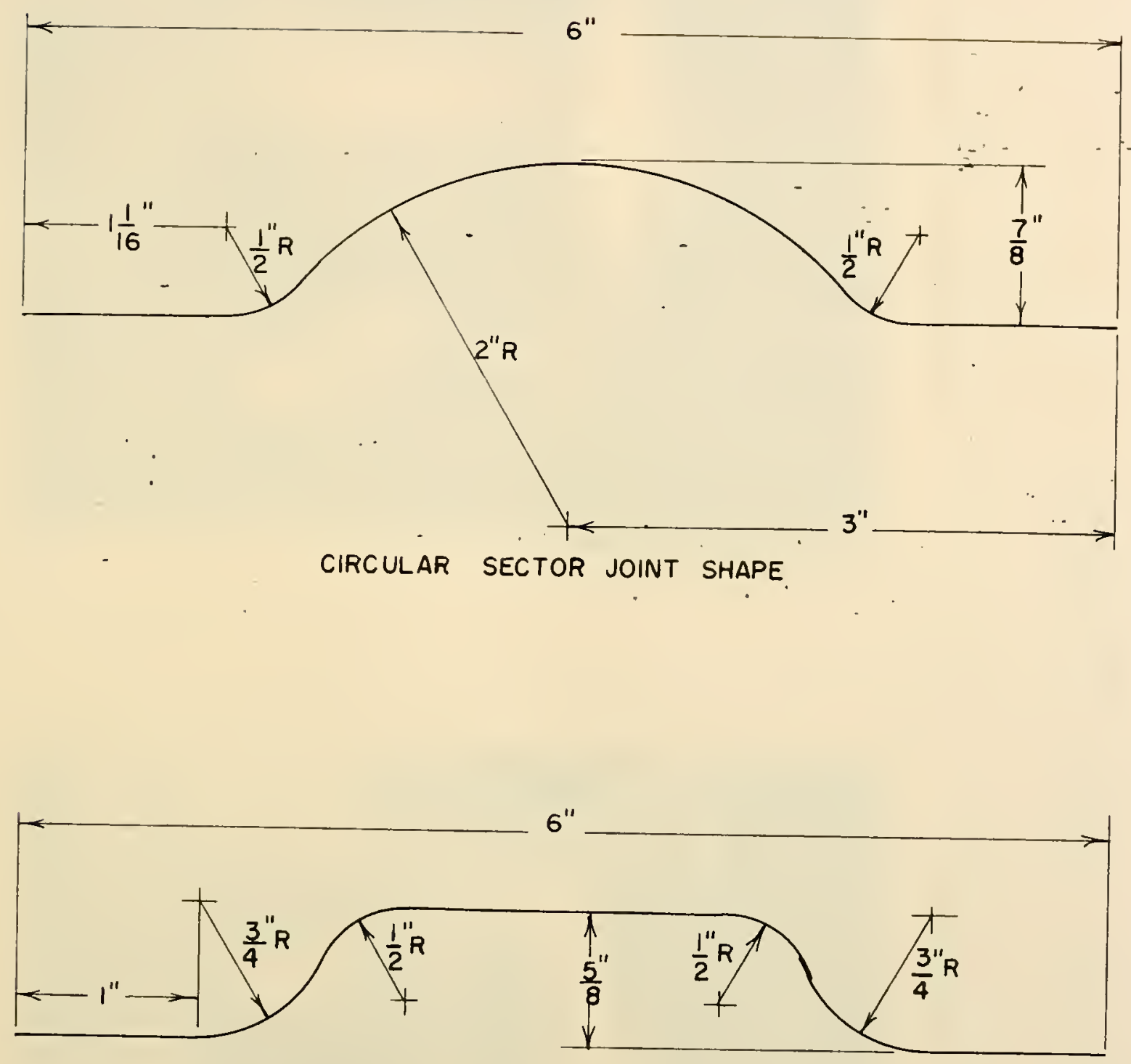

FLAT KEY - TYPE JOINT SHAPE

FIGURE 22. CONCRETE MODEL JOINT SHAPES 


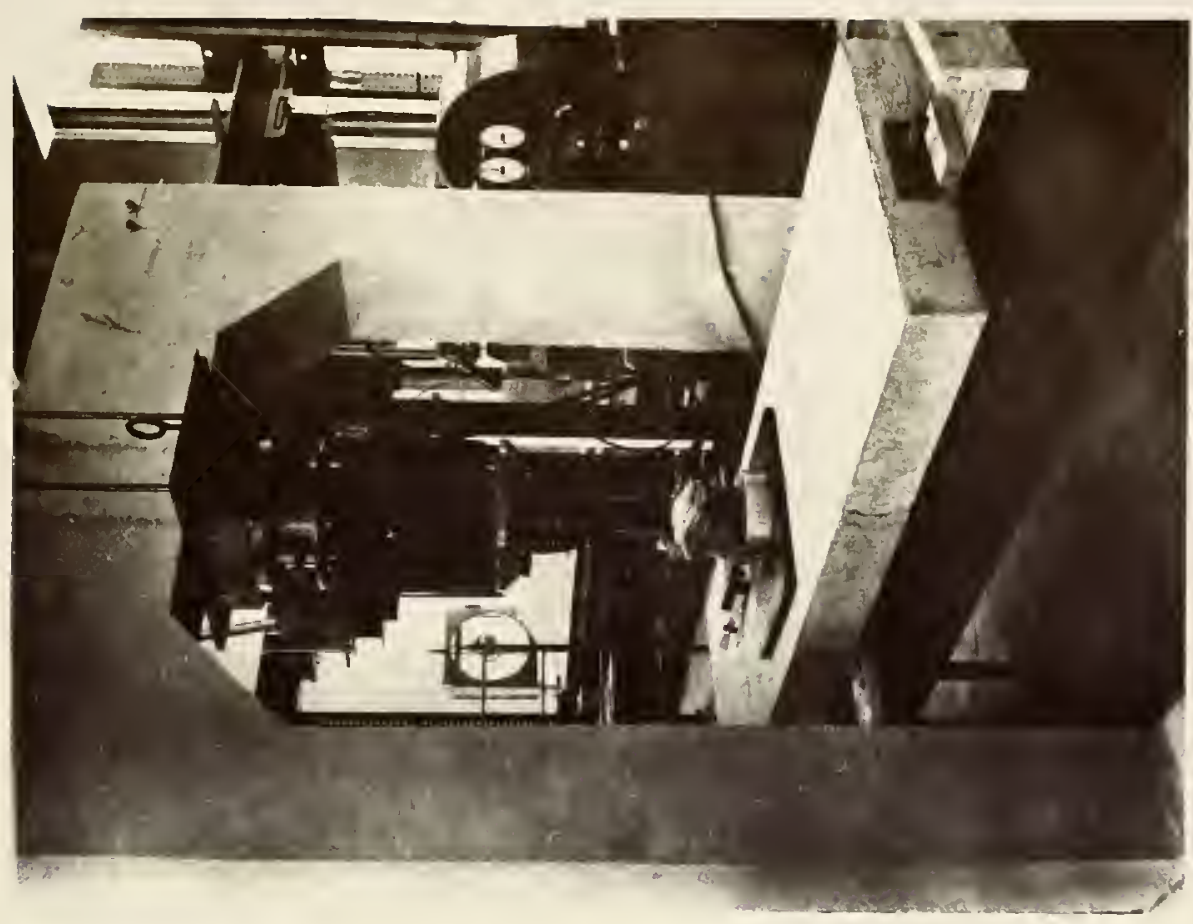

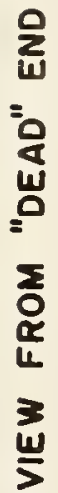

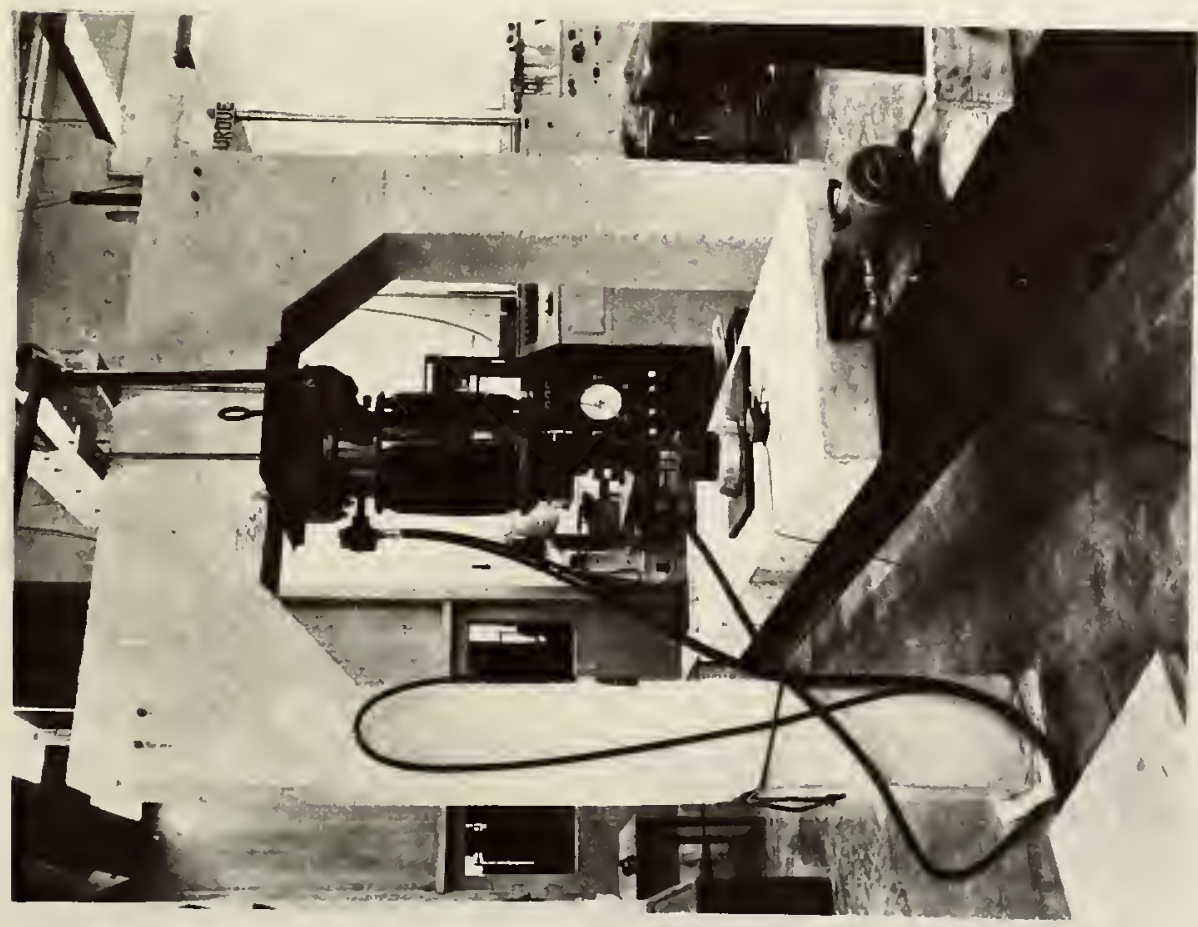

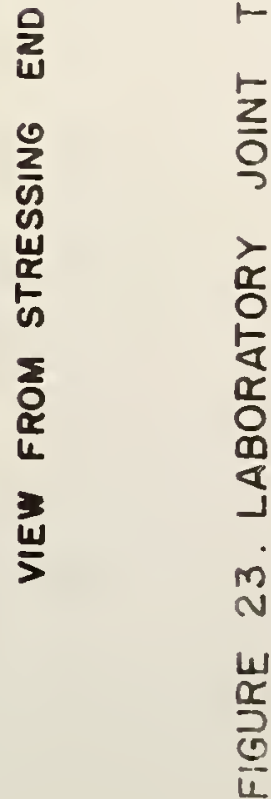


cycies of loading had been completed. The loading varied sinusoidally between $2.5 \mathrm{kips}$ and the maximum (described above) during each load cycle.

Flat Joint Model. The models for the flat joint examination were cast in the same manner as the models for the partial circle joint. The dimensions of the specimens were similar to those of the partial circle specimens. A maximum load of 12 kips and a minimum load of 2 kips were maintained throughout the test. The load was applied in the same manner and at the same rate, $250 \mathrm{cpm}$, as in the partial circle foint test. A post-tensioning force of 8,000 Ib was maintained, creating a stress in the gross concrete section of 40 psi. The loading was contimously maintained for $2,255,800$ cycles.

Both jolnt tests were conducted whthout instrumentation, with the exception of load indicators for the applied concentrated load and post-tensioning system. The object of the tests was to visually examine the performance of the joint under a repetitive load while approxImating the conditions of joint rotation which would be realized in a prototype deck system.

The slab sections were held to the beams with the bolt-clip arrangement described previously. Two bolt inserts were cast in each slab section with one insert located on each side of the supporting beam.

Results. The limited rosults indicated that the two joint sections would perform satisfactorily when exposed to the conditions of an actual bridge. No concrete wear or cracking was realized at the joints. The photoelastically determined failure patterns were not in evidence; 
this does not imply that the failure patterns would not be evident at higher post-tensioning loads, but would indicate that the failure patterns were not realized at the stress levels encountered during the testing.

- The siab tie-down. system was found to perform satisfactorily as the slabs were firmiy held to the beam with no loosening of the Iubricated bolts nor pull=out of the bolt anchors in evidence.

\section{Joint Materials}

$\vec{A}$ review of the photoelastic joint shape study Indicated the desirability of a material to reduce the stress concentrations at the - faces of the joint. The fringe photographs, Flgures 17, 18 and 19, display quite vividly the presence of stress concentration at the joint. Another important factor is the desire to prevent molsture from entering the joint, creating problems due to freezing and thawing as well as concrete deterforation due to chemical action fron thawing salts.

The requirements for a joint material are apparent. The material must have the ability to resist flow or creep under sustained load. This sustained load could be 20 years or more since the bridge deck with its post-tensioning is hoped to have a long service life. The material should be chemically resistant and should not deteriorate under the mild chemicals to be found on a deck mainly from de-icing chemicals. The material must be easily applicable to the joint and should conform easily to the joint; the material must be held in the joint at least until the adjacent section is in place whereupon it would be held by the adjoining sections. The material must also be stable under widely varylng temperatures, displaying no creep or brittleness due to 
situation where mumerous identical pieces would be manufactured.

\section{Design for Beam Spacing of Four-Feet}

The $4^{\prime}-0^{\prime \prime}$ conter to center beam spacing was selected as a small beam- spacing which would permit the examination of continuity over supports; the ten foot member length would permit two spans. The design parameters and calculations are presented:

Concrete Properties
a) $f_{c}^{\prime}=5,000 \mathrm{psi}$
b) $f_{t}^{c}=0$
c) $f_{c t}=4,000 \mathrm{psi}$
d) $f_{c}^{c 1}=2,000 \mathrm{psi}$

Stecl Properties
a) $f_{S}^{\prime}=250 \mathrm{ksi}$
b) $7 / 16 \mathrm{in}$. diameter strand
c) assume 20-percent losses

Conditions of support

a) wide-flange steel beams, flange width $83 / \mathrm{in}$.

b) beam spacing $4^{\prime}-0^{\prime \prime}$, continuous over three supports Loading
a) $\mathrm{HS} 20-44, P_{20}=16,000 \mathrm{Ib}$
b) $I=30$-percent of live-load moment
c) 6 inch deep deck
d) 35 psf future wearing surface

Although the Iaboratory specimens were to be loaded with static or repeated point loads, it was considered potentially desirable to examine the specimens when loaded to failure, after the completion of all other tests. For that reason, the impact as well as future wearing surface loads and full live load were included in the design.

Moment Calculations

$$
\begin{aligned}
& \text { AASilo effective span } " \mathrm{~s} n=4.0-\frac{8.75}{2(12)}=3.636 \mathrm{ft} \\
& \text { LLM }=0.8 \frac{(\mathrm{s}+2)}{32} P_{20}=2,260 \mathrm{ft}-\mathrm{lb} / \mathrm{ft}
\end{aligned}
$$




$$
\begin{aligned}
& I M=0.3\left(\mathrm{LJM}_{\mathrm{L}}\right)=678 \mathrm{ft}-1 \mathrm{~b} / \mathrm{ft} \\
& D L M=\frac{110}{8}(3.636)^{2}=182 \mathrm{ft}-1 \mathrm{~b} / \mathrm{ft} \\
& \text { Total moment }=3,120 \mathrm{ft}-1 \mathrm{~b} / \mathrm{ft}
\end{aligned}
$$

Section Properties

$\therefore$ For the 3'-0" $\times 6$ " slab, assuming $8-7 / 26$ in. prestress-

Ing strands:

$$
\begin{aligned}
& I=\frac{36(6)^{3}}{12}+5(8)(.1089)(1.5)^{2}=658 \mathrm{in}^{4} \\
& A_{c}=6 \times 36+5(8)(.1089)=-220.4 \mathrm{in.}^{2}
\end{aligned}
$$

Stresses Under Service Ioad

Using the combine stress equation, $f_{c}=-\frac{P}{A} \pm \frac{M c}{I}$

where negative signs (-) represent compression and positive signs (+) represent tension,

$$
\begin{aligned}
& \frac{M C}{I}=\frac{3,120(3) 3(12)}{650}=512 \mathrm{psi} . \\
& \frac{P}{A}=\frac{8(15,110)}{220.4}=548 \mathrm{psi}
\end{aligned}
$$

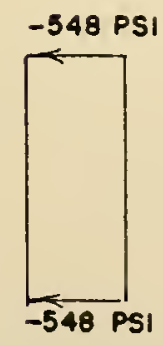

DIRECT AXIAL PRESTRESS
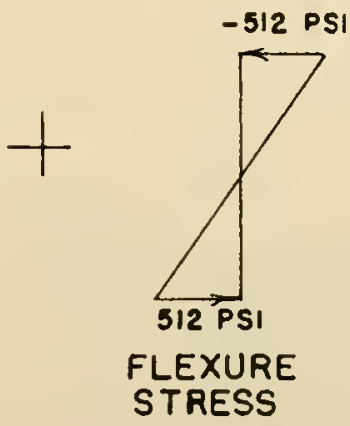

FLEXURE

STRESS

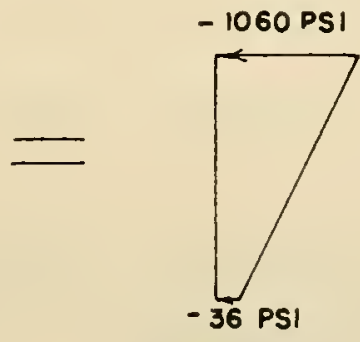

COMBINED

STRESSES

FIGURE 24. CALCULATED CONCRETE STRESSES DUE TO AASHO LOADING APPLIED TO LABORATORY SPECIMENS REINFORCED FOR $4^{\prime}-0^{\prime \prime}$ BEAM SPACING 


\section{Un timate Flexural Strength}

Required flexural strength is $1.5 \mathrm{DLM}+2.5$ (IJM + IM) or $22,869 \mathrm{ft}-1 \mathrm{~b}$.

Neglecting the top row of prestressing steel, $P=\frac{A_{S}}{b d}=.00268$. $\because$

From before, Mu $=A_{s} f_{s u}^{\prime d}\left(I-0.6 p \frac{f_{s u}}{f_{c}^{1}}\right)$ and

$f_{\text {su }}=f_{s}^{\prime}\left(1-0.5 p \frac{f_{s}^{\prime}}{f_{c}^{\prime}}\right)=23 \dot{k s i}$. The requirement that $p \frac{f_{\text {su }}}{f_{c}^{\prime}}$ must be less than 0.3 is met as the quantity has the value 0.125 . The ultimate moment, Mu, is then found to be $424 \mathrm{in}$. - k or $35,400 \mathrm{ft}-1 \mathrm{~b}$. The required ultimate moment capacity is exceeded by the calculated capacity.

\section{Design for Beam Spacing of Eight Feet}

The design parameters remain the same as in the design for four-foot bean spacing with the following exceptions:
a) $f_{s}^{\prime}=270 \mathrm{ksi}$
b) simply supported slab with 8'-0" beam spacing
c) $f_{t}=3 \sqrt{f_{c}^{1}}=212 \mathrm{psi}$, AASHO 1.6 .7

In this design it will be noted that the continuity factor (.8) for continuous slabs has not been used since the laboratory slab is essentially simply supported and is not continuous.

Moment Calculations

$$
\begin{aligned}
& \text { AASIOO offective span "s" }=7.635 \mathrm{ft} \\
& \text { LLM }=\frac{(s+2)}{32} P_{20}=4.810 \mathrm{ft}-1 \mathrm{~b} / \mathrm{ft} \\
& I M=.30(\mathrm{LIM})=1,4 \mathrm{~L} 2 \mathrm{ft}-1 \mathrm{~b} / \mathrm{ft} \\
& D L M=\frac{W(\mathrm{~s})^{2}}{8}=\frac{110(7.635)^{2}}{8}=801 \mathrm{ft}-1 \mathrm{~b} / \mathrm{ft} \\
& \text { Total Moment }=7,053 \mathrm{ft}-1 \mathrm{~b} / \mathrm{ft}
\end{aligned}
$$

\section{Section Properties}

For the 3'-0" wide slab, assuming $12-7 / 16$ in. diameter 
temperature changes.

Laboratory Evaluation. The laboratory investigation consisted of placing the joint material in the joint of the flat-joint concrete model which had been used previously in the evaluation of the joint shape. A dike was constructed on top of the system shown in Figure 23 and was subsequently flooded in order to examine the effectiveness of the joint material with regard to protection of the joint from moisture. The flooded area measured approxdmately 24 inches by 6 fest, crossing all three joints in the model. By means of a flashing strip and flashcompound, the water within the dike was contained and could not flow laterally under the dike which was constructed of 2 in. by. 2 in. wood strips. The joint material covered the entire width of the models and had a one-inch hole cut in it to facilitate passing of the post-tensioning strand.

The first material which was examined was asbestos cloth, both plain and wire reinforced. The cloth was held on the convex side of each joint with an MC 70 asphalt. The system was post-tensioned, then the dike was flooded with water to a depth of approximately one-half inch. The undesireability of the material was evident after a fer hours of flooding as the capillarity of the cloth permitted the water to pass through the entire depth of the slab. One joint was faced with the wire-reinforced cloth and the other two were faced with the plain cloth.

Capillarity was very evidently at fault as the water passed laterally to the full depth of the unflooded portion of the joint. For this reason, the asbestos cloth was removed from further consideration. The same specimens were then fitted with $1 / 16$ in. U60 neoprene 
sheet as the joint material. The dike was replaced on the top of the sections and water-tightness was again secured. The post-tensioning cable was tightened to seat the slab pieces and the joint material. Once assured that the joint was mechanlcally tight the post-tensioning cable was allowed to slacken and, the slab was flooded to a depth of one-half inch with water. No evidence of water passage was noted at any place on the three joints after 24 -hours, this being accomplished with no post-tensioning force applied across the jolnt. The Neoprene sheet was sufficient to prevent water from entering the joint and was satisfactory in that respect.

- Following the water test, the section was dried, and a posttensioning force of approximately $\dot{8}, 000$ pounds was applied. The system was then subjected to 3.5 million cycles of repeated load of 9,000 pound maximum and 1,000 pound minimum applied concentrated load similar to the concrete joint test, for whlch the testing arrangement is shown in Flgure 23. The joint was dry in order that wear of the material could be observed wi thout the lubricating effect of the water. Upon removal of the load and post-tensioning force, no significant change in the appearance of the material was noted. There was efldence present where slight irregularities in the jolnt shape had made depressions in the neoprene, but no tearing or buffing was found.

Neoprene is considered to be effective with regard to sealing and wearability for application on a briage deck. Chemical resistance could be specified by American Society for Testing and Materials standards as could compression set and temperature performance desired. 
DESICN OF PRESTRESSED LABORATORY SPECTMENS

The laboratory specimens were designed for beam spacings of elght. and four feet. It was desired to examine sections which were designed for small as well as large beam spacings in order to examine the response of the deck in likely configurations.

A size of 10 feet in the transverse direction and 12 feet in the longitudinal direction was chosen as a practical dimension with consideration given to the available laboratory testing and handling facilities. A deck element $3^{\prime}-0$ " wIde by 6 inches deep by 10 feet long was then selected. This would permit reinforcing two sections for the large beam spacing and two sections for the small beam spacing, thereby meeting the $12^{\prime}-0^{\prime \prime}$ dimension.

In the followling designs, reference is made to the general deck design calculations, which were presented above, for the applicable AASHO speciflcations. Where new specifications are applied, the specification and its designation are presented.

In both cases, the steel centroid is located at $I^{\frac{1}{2}}$ inches from both the top and bottom of the slab, as opposed to the lis inches clear cover in the previous general design. The steel location deviates from the general deslgn case in order that the laboratory specimens could be fabricated in prestressing beds whose strand placement templates were 1 already available. It should be noted that the cost of a template for forming for $1 \frac{1}{2}$ inches clear cover would be justifled in a prototype 
prestressing strands:

$$
\begin{aligned}
& I=\frac{36(6)^{3}}{12}+5(12)(.1089)(1.5)^{2}=663 \mathrm{in.}^{4} \\
& A_{c}=6 \times 36+5(12)(.1089)=222.5 \mathrm{in.}^{2}
\end{aligned}
$$

Stresses Under Service Load

$$
\begin{aligned}
& \frac{P}{A}=\frac{12(17,360)}{222.5}=935 \mathrm{psi} \\
& \frac{M C}{I}=\frac{7,053(3) 3(12)}{663}=1,146 \mathrm{psi}
\end{aligned}
$$
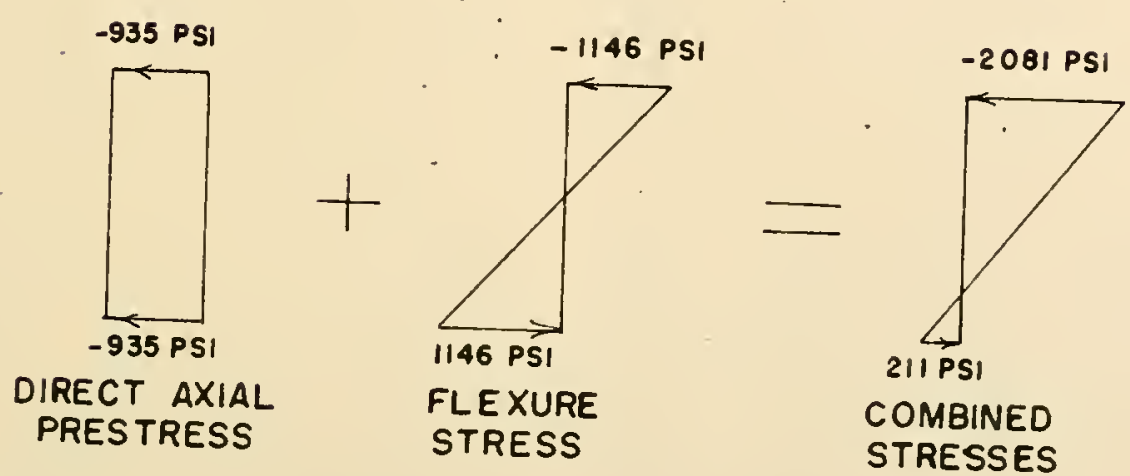

\section{FIGURE 25. CALCULATED CONCRETE STRESSES DUE TO AASHO LOADING APPLIED TO LABORATORY SPECIMENS REINFORCED FOR 8'-O" BEAM SPACING}

Ultimate Flexural Strength

The required flexural strength is 1.5 (DLM) +2.5 (IIM + IM); the value of the expression is $50,550 \mathrm{ft}-1 \mathrm{~b}$.

Neglecting the top row of prestressing steel, $P=\frac{A_{s}}{b d}=\frac{6(.1089)}{36(4.5)}$ $=.00402$. Again, $M u=A_{s} f_{s u} d\left(I-0.6 p \frac{f_{s u}}{f_{c}^{\prime}}\right)$ and $f_{s u}=f_{s}^{\prime}$ ( $\left.1-0.5 \mathrm{p} \frac{f_{s}^{\prime}}{f_{c_{f}}^{\prime}}\right)$. Evaluating, $f_{s u}=270(.8915)=241 \mathrm{ks1}$. The requirement that $p \frac{{ }^{f_{s u}}}{f_{c}^{3}}$ must be less than 0.3 is met as the quantity has the value 0.194 . The ultimate moment is then found to be $62,500 \mathrm{ft}-\mathrm{lb}$; the required uItimate capacity is exceeded by the calculated capacity. 


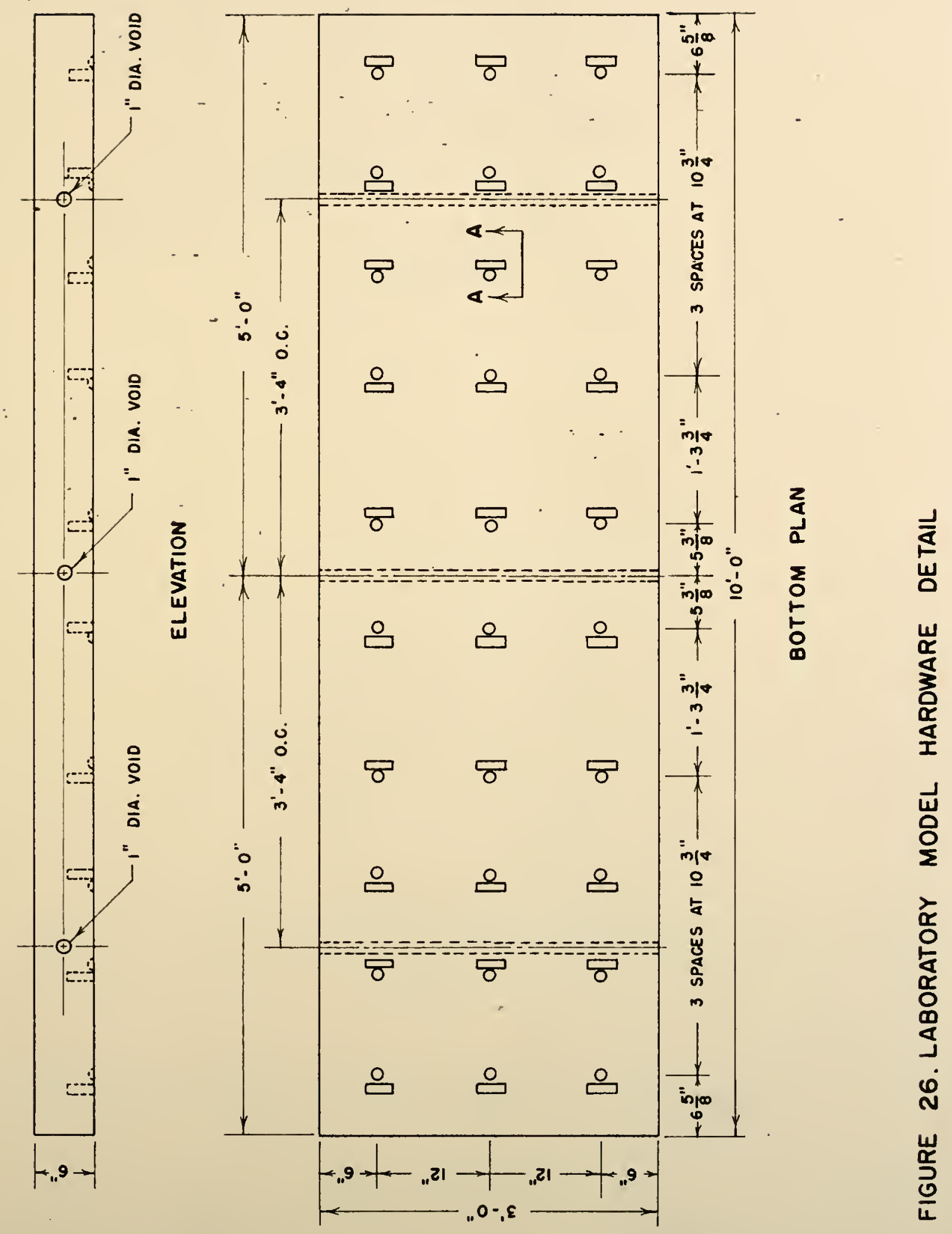



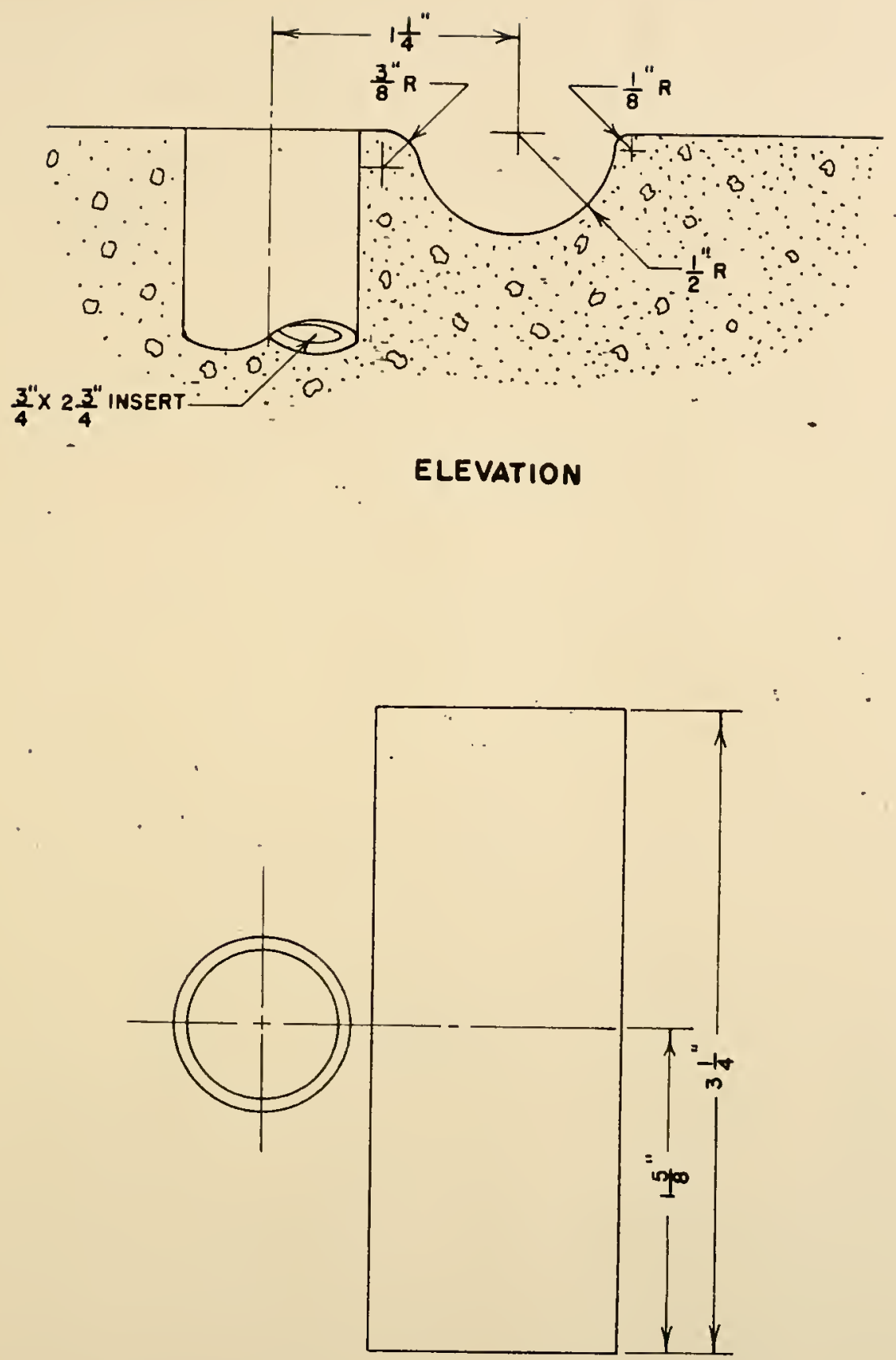

PLAN

FIGURE 27. DETAIL A-A, BOLT INSERT ARRANGEMENT 

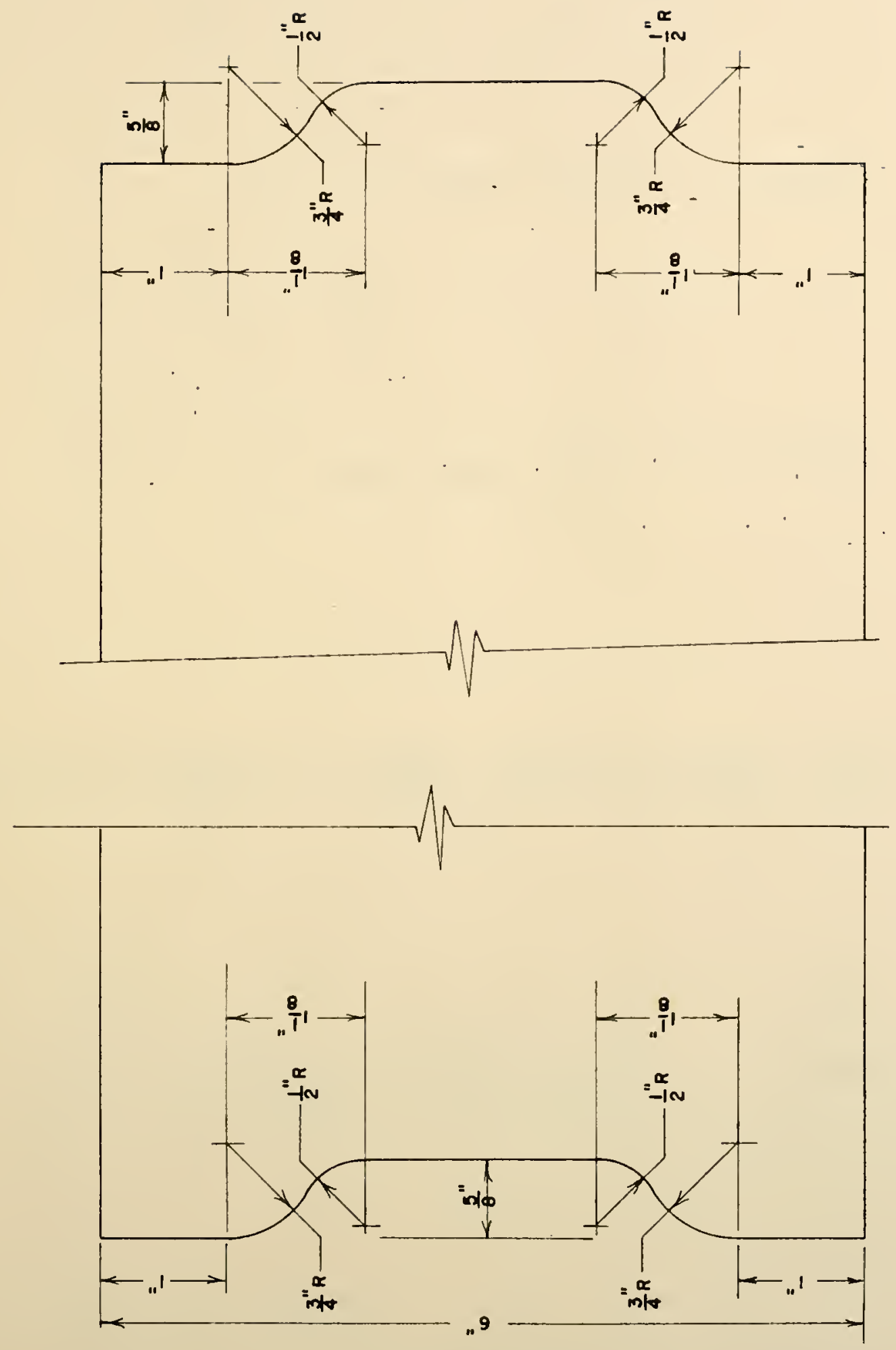

崖

$\frac{5}{2}$

히음

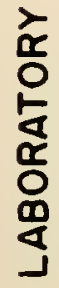

$\stackrel{\infty}{N}$

$\frac{w}{\frac{\pi}{2}}$ 

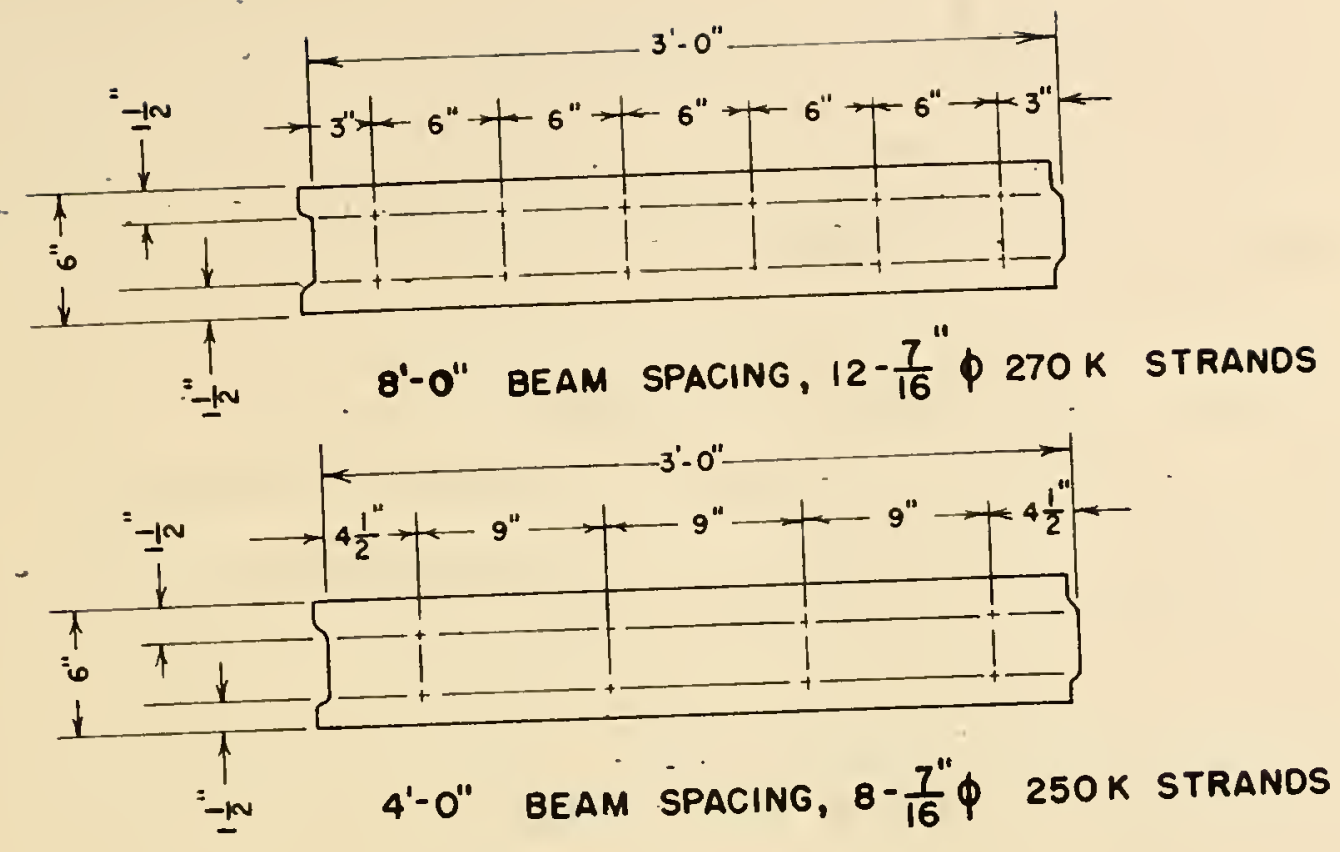

FIGURE 29. LABORATORY MODEL STRAND PLACEMENT PATTERNS
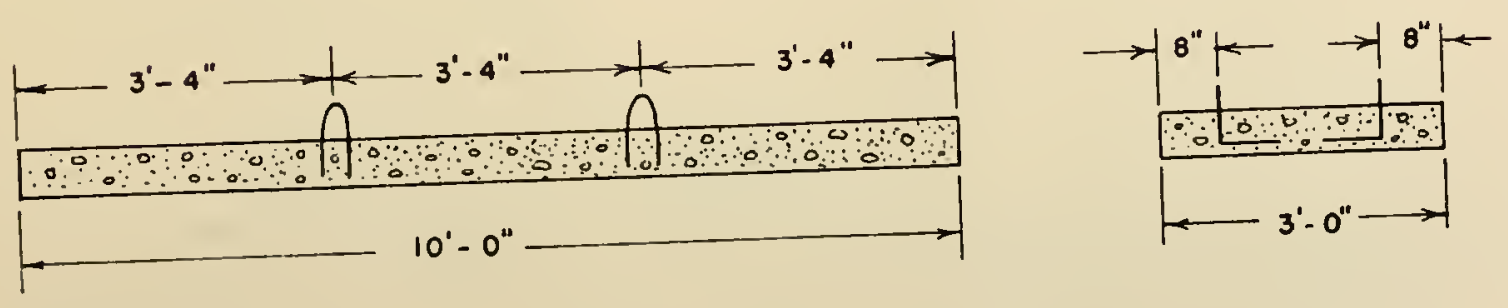

FIGURE 30. LABORATORY MODEL LIFTING LOOP DETAIL 
CONSTRUCTION OF THE PRESTRESSED CONCRETE ELENEATS

Precast construction of the highest quality is absolutely necessary if the concept of procast, prestressed concrete bridge decks is to succeed through actual application. The enviroment of the precasting yard is much more favorable for the mixing, placing, and curing of concrete than is the actual bridge site. Precasting in itself does not insure that the finished product will be of higher quality but all factors involved would point out the fact that a superior finished product should be realized. The precast, prestressed deck sections which were used for the laboratory testing were manufactured by Construction Products Corporation, Prestressed Concrete Division, of Lafayette, Indiana. The design of two differently reinforced elements which were manufactured appears above. Hereafter, the eight-foot section will refer to the two deck elements reinforced for eight-foot beam spacings, and the four-foot section will refer to the two deck elements reinforced for four-foot beam spacing.

\section{Formwork}

The formwork for the three-foot wide sections was provided by a prestressing bed which is normally used to cast 45 in. wide by 21 in. deep prestressed concrete box girders. Figure 31 indicates the forming procedure. The prestressing strands are placed in two rows running the entire length of the precasting bed. Diaphragms are placed along the 


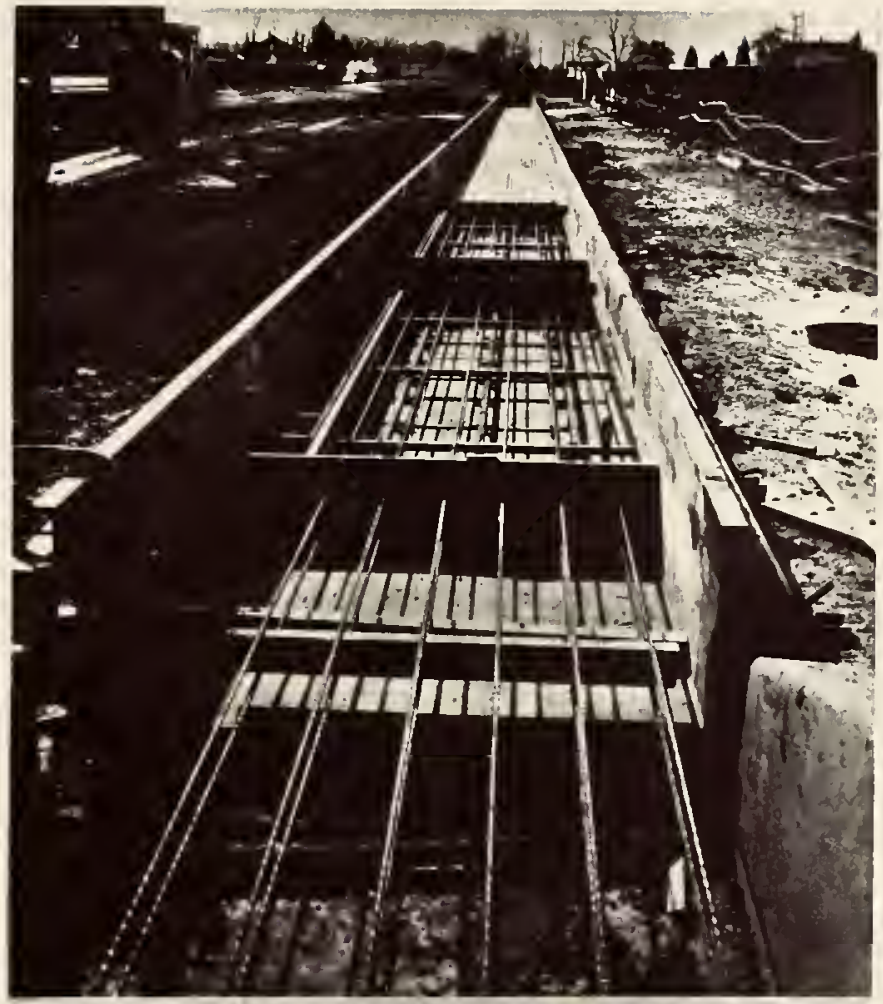

LONGITUDINAL VIEW OF PRECASTING BED WITH PRESTRESSING STEEL IN PLACE

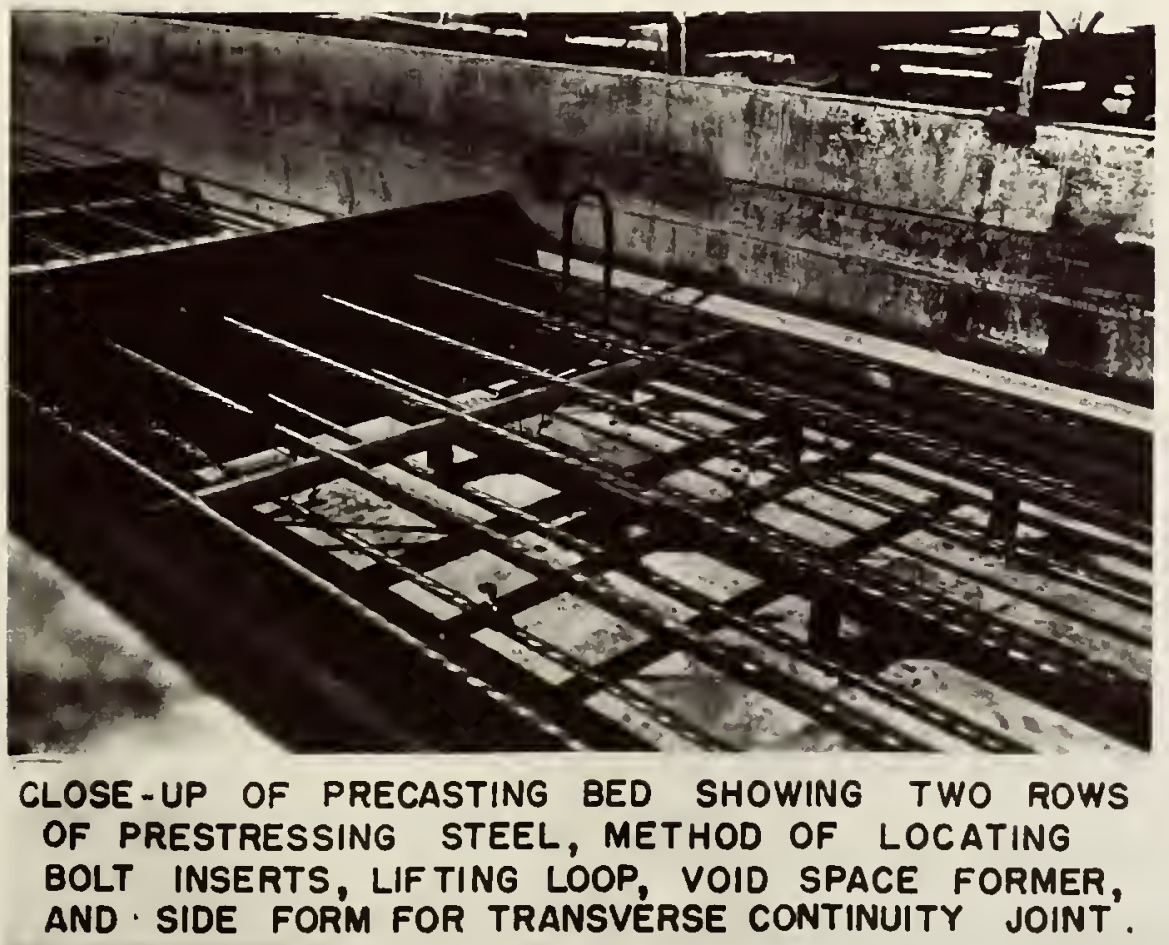

FIGURE 3I. PRECASTING METHOD FOR LABORATORY SPECIMENS 
length of the bed at the desired length of the mamber to be cast with approximately a one-foot space between sections to facilitate strand cutting between the members. The transverse continuity joint for the deck elements was cast in the longitudinal direction on the precasting bed, with one side of the joint form blocked away from the sidewall of the precasting bed in order to cut the 45 in. width of the precasting bed to the desired $36 \mathrm{in}$. dimension. Plywood sheet had been placed beneath the area of the elements to be cast to achieve the desired concrete cover while using the available end-block templates for the bed.

\section{Bolt Inserts}

The bolt inserts, capped on the bottom with a plastic cap, were positioned by welding to a frame constructed of $1 / 8$ in. $x I$ in. strap Iron. The frame was welded outside the form and placed inside the form prior to concrete and strand placement. This method was observed in the laboratory to be dimensionaly accurate and acceptable. Difficulty was encountered after casting, as in some instances water laden with cement had entered the insert, presumably from the top. After cleaning the threads with a $3 / 4$ in. tap, no further difflculty was encountered. This problem could be eliminated either by capping the insert or by application of a bond-breaker to the threads of the insert; a petrolatum would probably be sufflclent and would not tend to flow out of the insert.

Care mast also be exercised in the forming of the indentation adjacent to the insert (see Figure 27) which accepts the projection on the spring cl1p. Some of the indentations on the laboratory specimens were found to be inaccurately located; this would not be acceptable in 
a prototype situation as the full usefulness of the bolt-clip arrangement could not be realized. It is recomnended that the $1^{\frac{1}{4}}$ in. dimension of Figure 27, elevation view, be considered an exact or hold dimension, as the clip will only be accommodated by this dimension. The $3 \frac{1}{4}$ in. dimension must also be centered for the full usefulness to be realized. An increase of this dimension to 4 " is recomended.

\section{Concrete}

The concrete strength specified for the laboratory test specimens was 5,000 psi at 28 days; this strength was achieved in seven days: and the strength versus time relationship for the eight-foot and fourfoot sections appears as Figure 32. The curve appears to level-off at slightly above 6,500 psi compared to the specified 5,000 psi value.

The greatest precaution to be taken as far as concrete strength is concerned is to provide adequate concrete strength at the time that the prestressing strands are released. If the concrete does not have sufficient strength, cracks due to slip of the prestrossing steel may occur along the surface of the slab immediately above or below the steel. The two eight-foot specimens had a 24 -hour concrete strength of 4,140 psi and no cracking of the concrete along the prestressing steel was observed. However, the four-foot sections exhibited an evident crack pattern above the prestressing strand. (See Figure 33.) The one day strength at the time of release of the strand was tested by the manufacturer and found to be 4,570 psi. A seven-day strength test was performed in the laboratory and concrete strength was then indicated as $4,390 \mathrm{psi}$. The variation in cylinder strengths could indicate a discrepancy in casting, curing, or testing the concrete cylinders. 


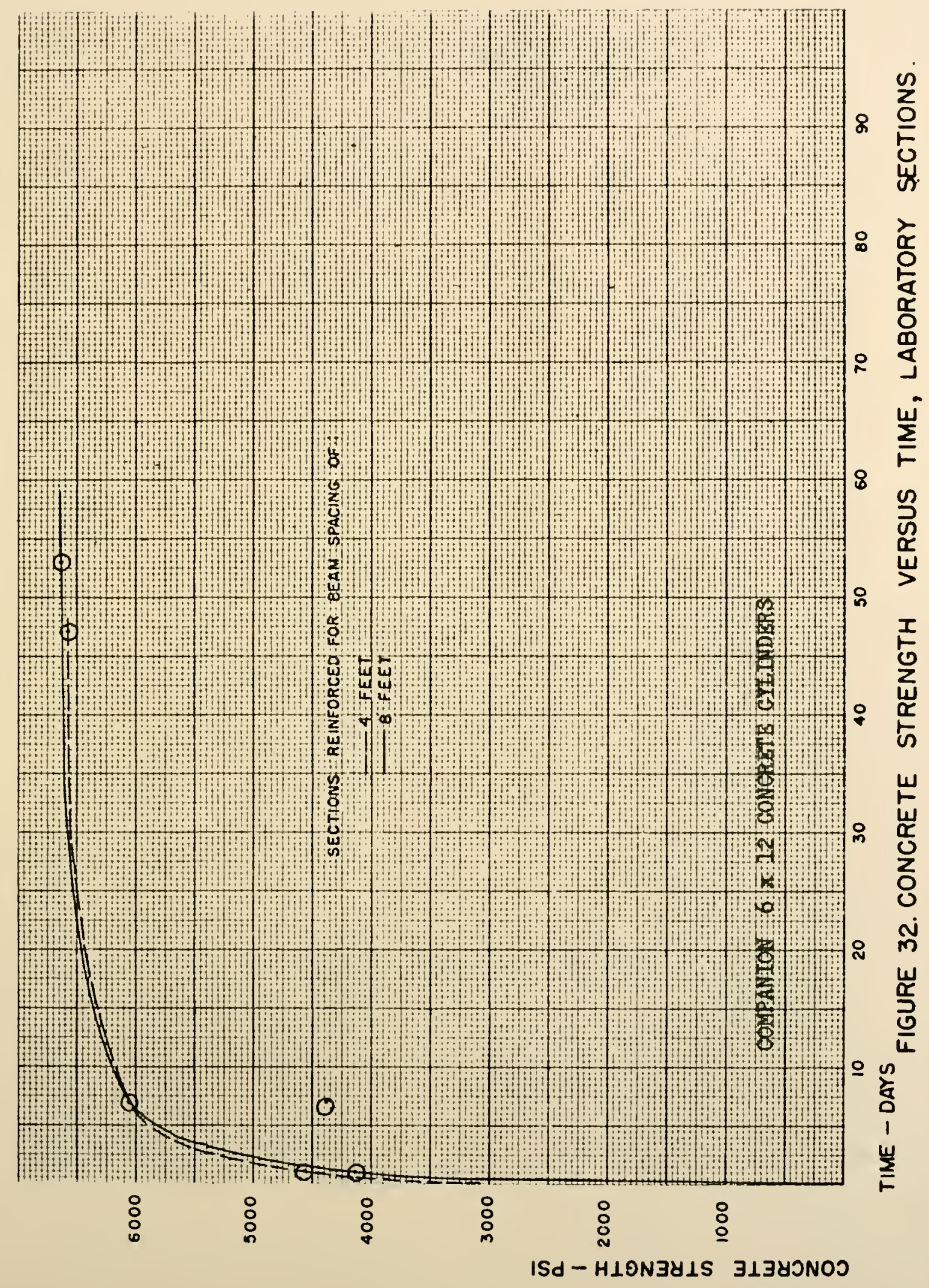



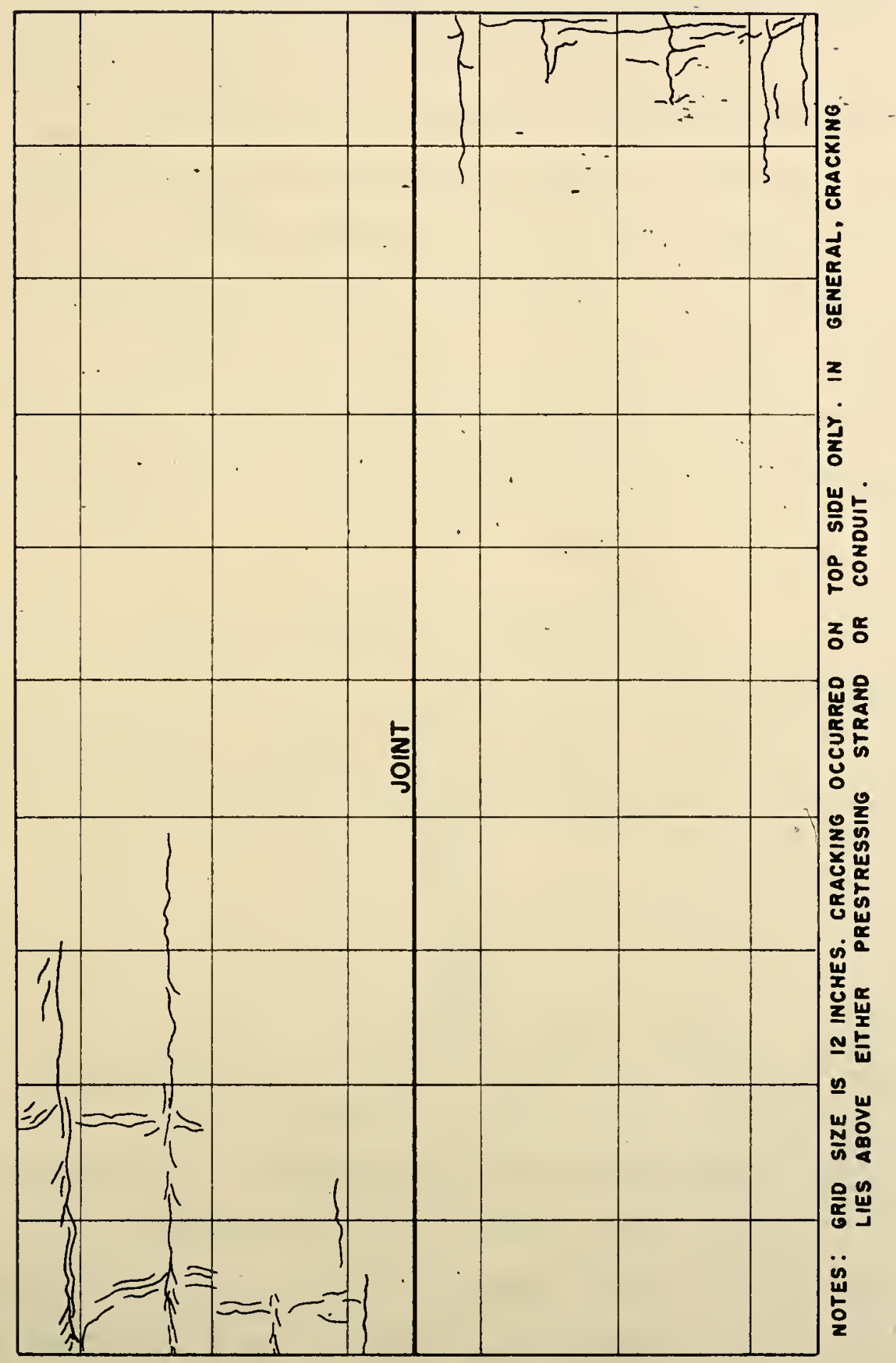

$\frac{\frac{0}{2}}{\frac{0}{1}}$

$=0$

0

0
$u$
0
0
$\frac{1}{2}$
$\frac{1}{\alpha}$

$\frac{2}{0}$

2

$\frac{c}{2}$
$\frac{1}{\sigma}$
$\frac{1}{\alpha}$
$\frac{1}{0}$
$\frac{\alpha}{0}$

$m$

$\frac{4}{\frac{1}{6}}$ 
In light of the cracking along the prestressing strand, it is possible that the furl strength indicated by the test cylinder at one day was not attained by the slab.

An average value for the initial tangent modulus of elasticity of the concrete in the eight-foot sections, at 53 days, was found to be $3.65 \times 10^{6} \mathrm{psi}$ and an average value for the four-foot sections tested at 47 days was found to be $3.86 \times 10^{6}$ psi. A split tension test was made for each pour and the eight-foot section showed a splitting tensile strength of $556 \mathrm{psi}$ and the four-foot sections showed a splitting tensile strength of 615 psi, at the same ages as the modulus of elasticity tests.

Table 4. Concrete Properties of Test Specimens

\begin{tabular}{|c|c|c|c|c|c|}
\hline $\begin{array}{l}\text { Section Reinf. } \\
\text { for Beam Spacing }\end{array}$ & $\begin{array}{l}\text { Age } \\
\text { (days) }\end{array}$ & $\begin{array}{c}f_{c}^{\prime} \\
(p s i)\end{array}$ & $\begin{array}{c}f_{t} \\
\text { (psi) }\end{array}$ & $\begin{array}{c}\mathrm{E}_{c} \\
\text { (psi) }\end{array}$ & \\
\hline $\begin{array}{l}81 \\
81 \\
8 i\end{array}$ & $\begin{array}{r}1 \\
7 \\
53\end{array}$ & $\begin{array}{l}4140 \\
6050 \\
6625\end{array}$ & 556 & $3.65 \times 10^{6}$ & (ave. of two) \\
\hline $\begin{array}{l}4^{\prime} \\
4^{\prime} \\
4^{\prime}\end{array}$ & $\begin{array}{r}7 \\
7 \\
47\end{array}$ & $\begin{array}{l}4570 \\
4390 \\
6585\end{array}$ & 615 & $3.86 \times 10^{6}$ & (ave. of two) \\
\hline
\end{tabular}

Curing of the concrete is important as far as the driving surface is concerned. If steam curing is used, care should be exercised to protect the slab from water which condenses on the tarpauin covering the slab and then drips to form pock marks on the surface of the slab. These irregularities cause not only a rough, unsightly surface but also would lead to further deterforation as the edges of the shallow hole would become worn and enlarged by trafflc. 


\section{Concrete Placement}

Concrete placement in the laboratory samples was accomplished by hauling, by fork lift, the concrete bucket which was filled at the plant concrete mixer. The bucket was carried approximately $200 \mathrm{ft}$. to the casting bed where the fork IIft raised the bucket over the form to deposit the concrete. Once in the form the concrete was internally vibrated, then trowelled and finished by hand.

When sections are cast which use the full width of the precasting bed, some difficulty may be encountered in providing a uniform thickness. In the laboratory samples, variations in thickness were observed, particularly at the ends of the specimens. The producer must provide a specimen which is uniform in thickness or the rideability and structural soundness may be adversely affected. A means of checking the thickness seems necessary to bring about uniformity. Assuming that the procasting bed used is dimensionally uniform, a skid, such as the one illustrated in Figure 34 could be used to check the depth dimension over the ent1re width of the nember.

\section{Continuity Joint}

The transverse contimuity joint which was cast in the laboratory specimens (for shape see Flgure 28) was found to be dimensionally varying along its length. It is beliered that the joint form which was blocked (on the left side of the longitudinal view, Figure 3I) did not have sufflcient strength between blocks to resist the torsion induced between the blocks by the plastic concrete. As a result, the sideform rotated irregularly from point to point. This led to joints which did not flt when butted together in the laboratory and were brought to rough 


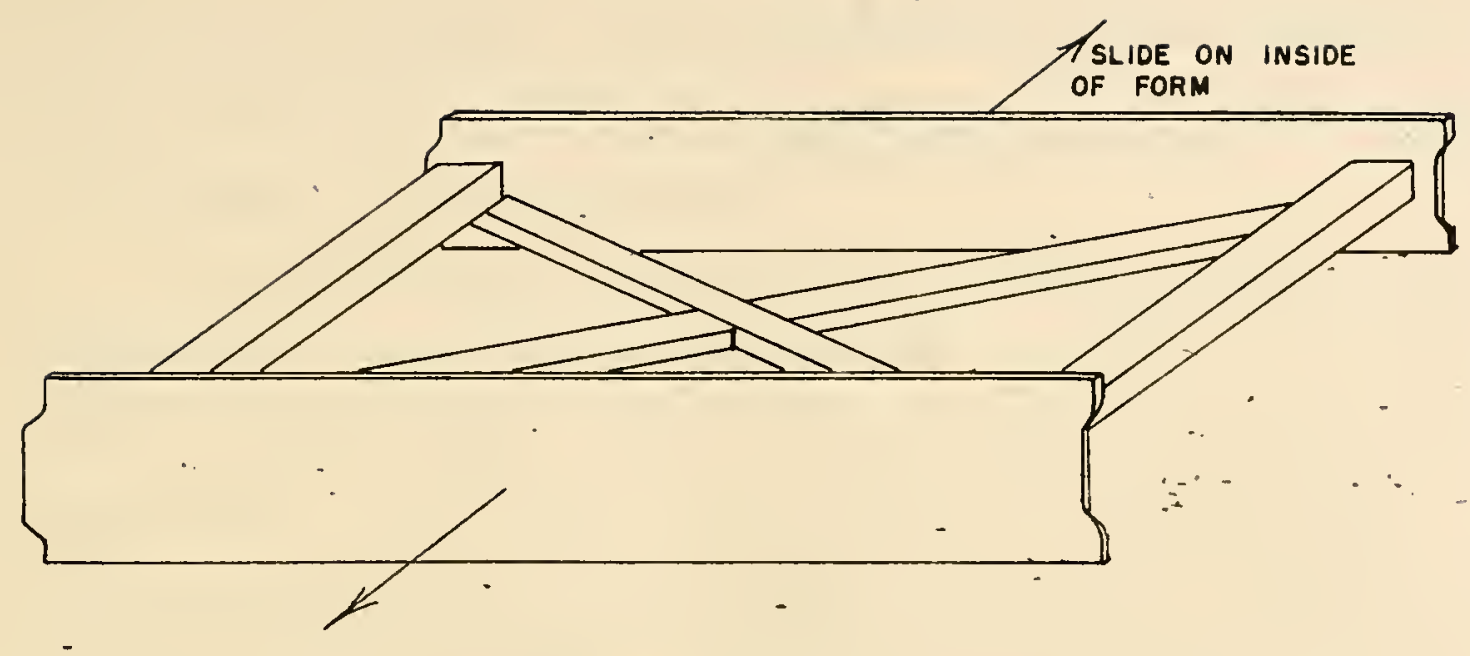

TEMPLATE FOR CHECKING DIMENSIONAL ACCURACY OF FORMWORK PRIOR TO PLACEMENT OF INTERNAL HARDWARE.

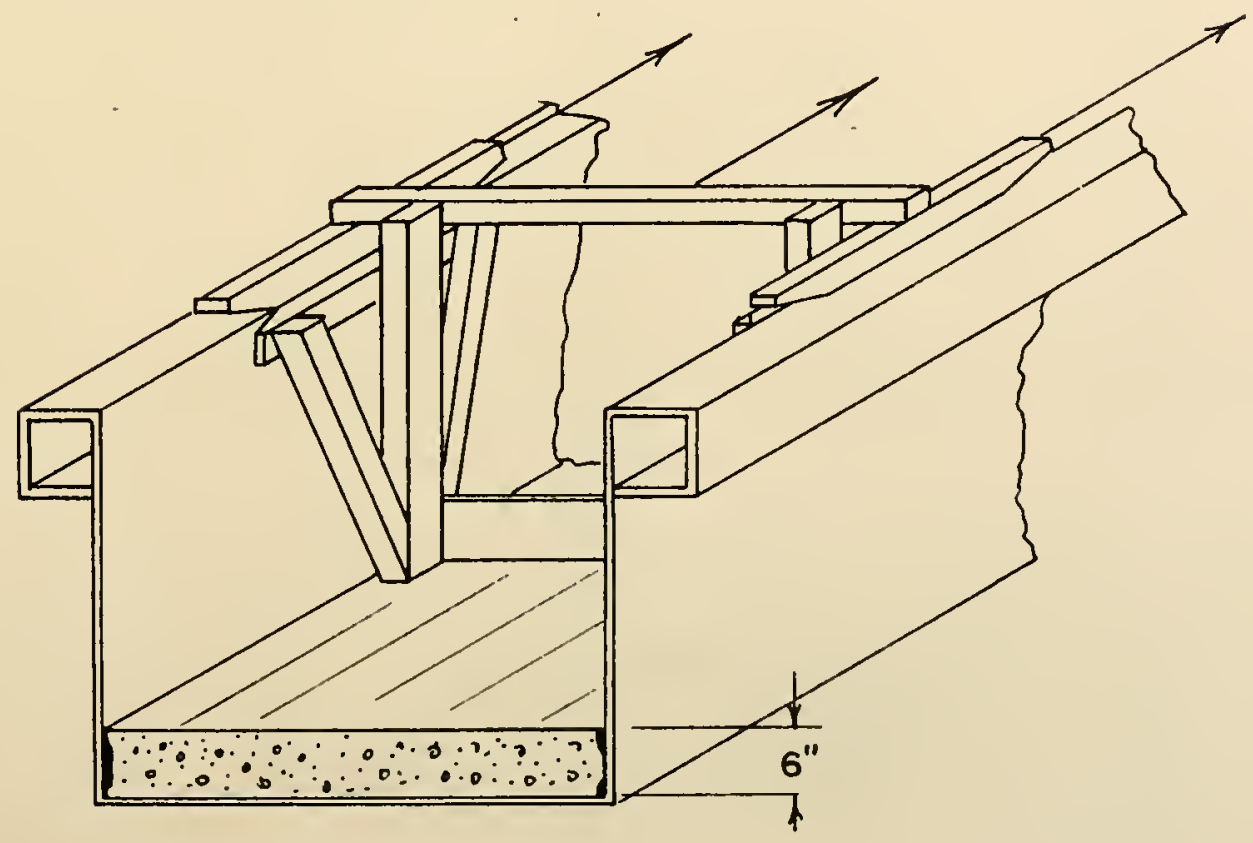

TEMPLATE FOR CHECKING DEPTH DIMENSION OF SECTIONS IMMEDIATELY AFTER CASTING.

FIGURE 34. TEMPLATES FOR DIMENSIONAL CONTROL 
fit only after grinding. Th1s problem should be self-rectifying in future applications as the form for both the joint faces will be fluxed to the sidewall of the box beam form.

To ensure a unfform product, the formwork should be checked with a template prior to placing the slab hardware. A template, constructed similar to the one shown in Figure 39 would be easy to construct and simple to use. If the formwork was arranged such that the template. could be passed while malntaining contact with the form, a uniform section, whose faces were in the correct dimensional relationship should be realized.

In an application on an actual bridge, it would prove worthwhile to butt and mark adjacent piecea to allow any necessary grinding or rearranging to be done prior to actual assembly where the working platform would be girders and stringers. 
LABORATORY TESTTHG OF FULL-SCALE DECK.

\section{Load Cell Design and Calibration}

- Cable Tension Cells. In order to monitor the force in each of the post-tensioning cables under all stages of loading, a load cell was designed and built for each of the three post-tensioning cables. The cells were used in a configuration where the load measured by the cell was the actual cable load. (See Figure 35)

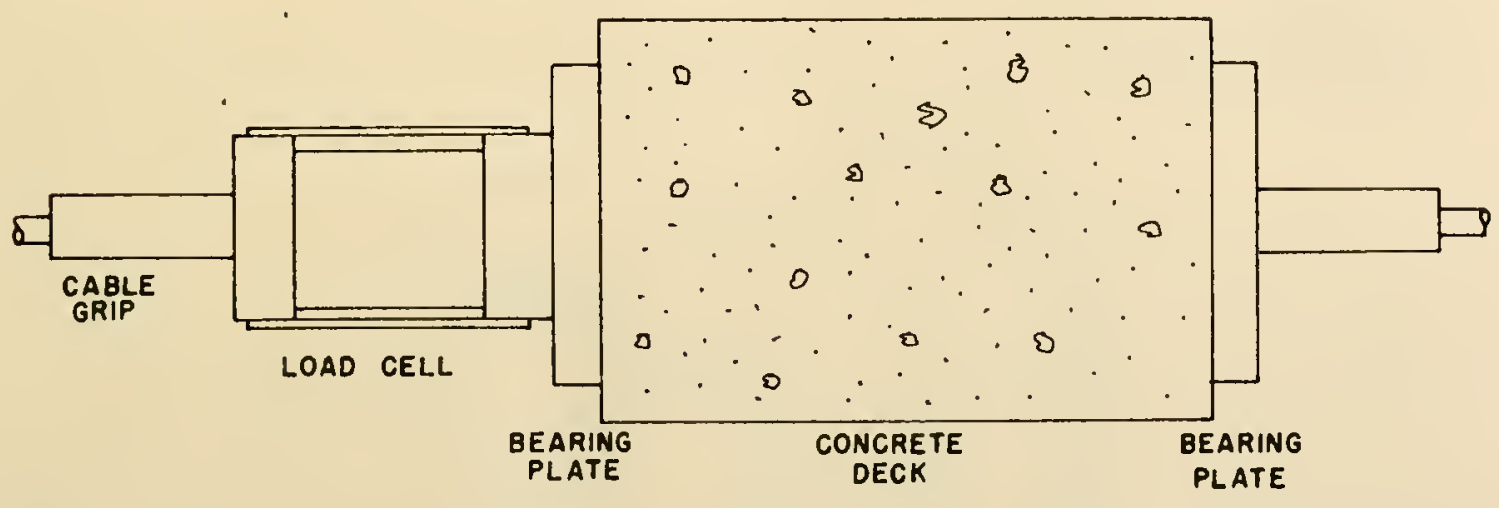

CABLE "DEAD" end

CABLE STRESSING END

FIGURE 35. POST-TENSIONING ARRANGEMENT IN LABORATORY

Detalled drawings showing the construction of the load cells as well as the strain gage clrcuit which was used appear in Figures 36 and 37. The cells are constructed of 6061-T6 alumimum.

Excellent output and sensitivity were obtained as indicated by the colibration curves, appearing as Figures 38, 39, 40. Iinearity is 

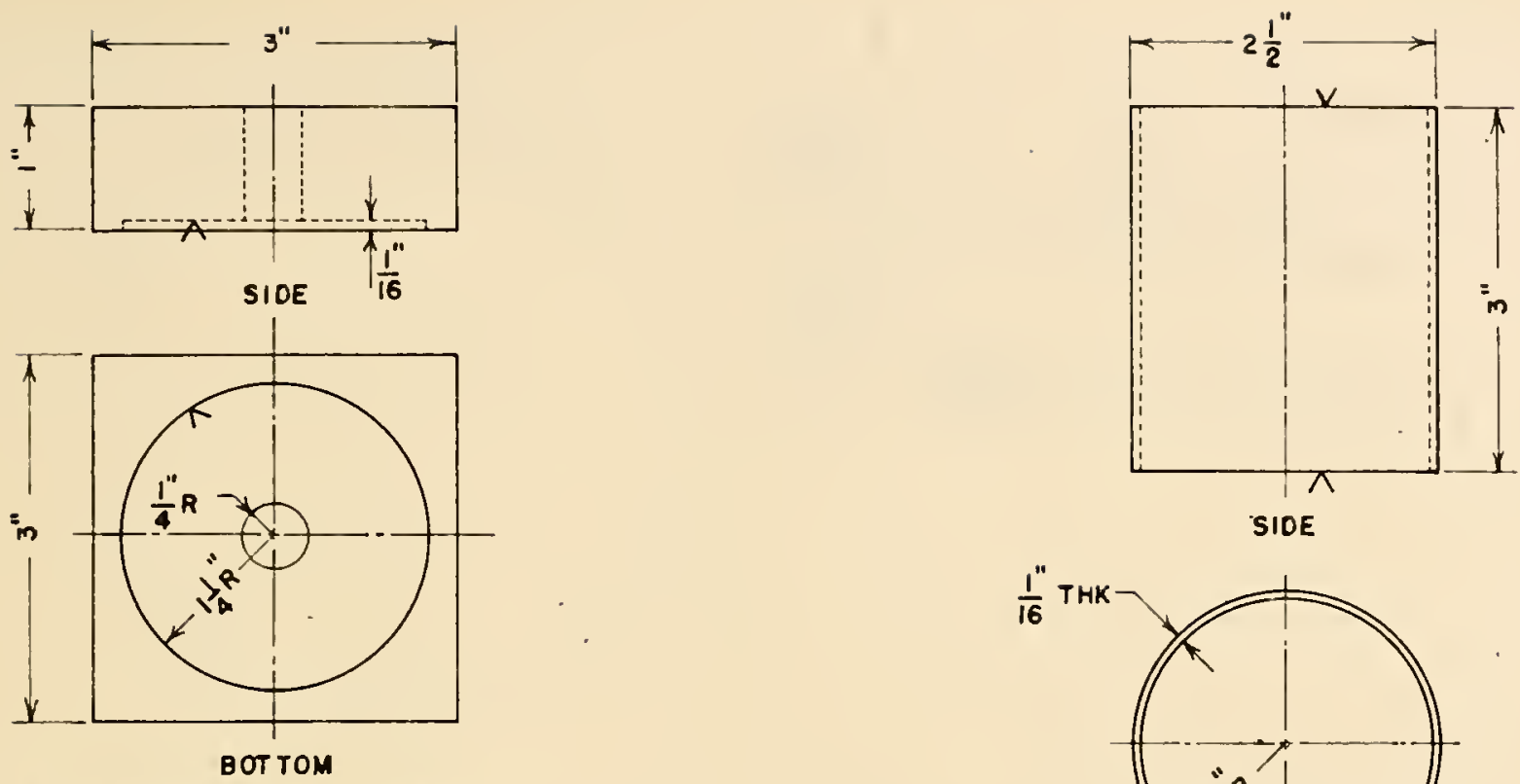

END BEARING BLOCK, 2 REO'D PER CELL
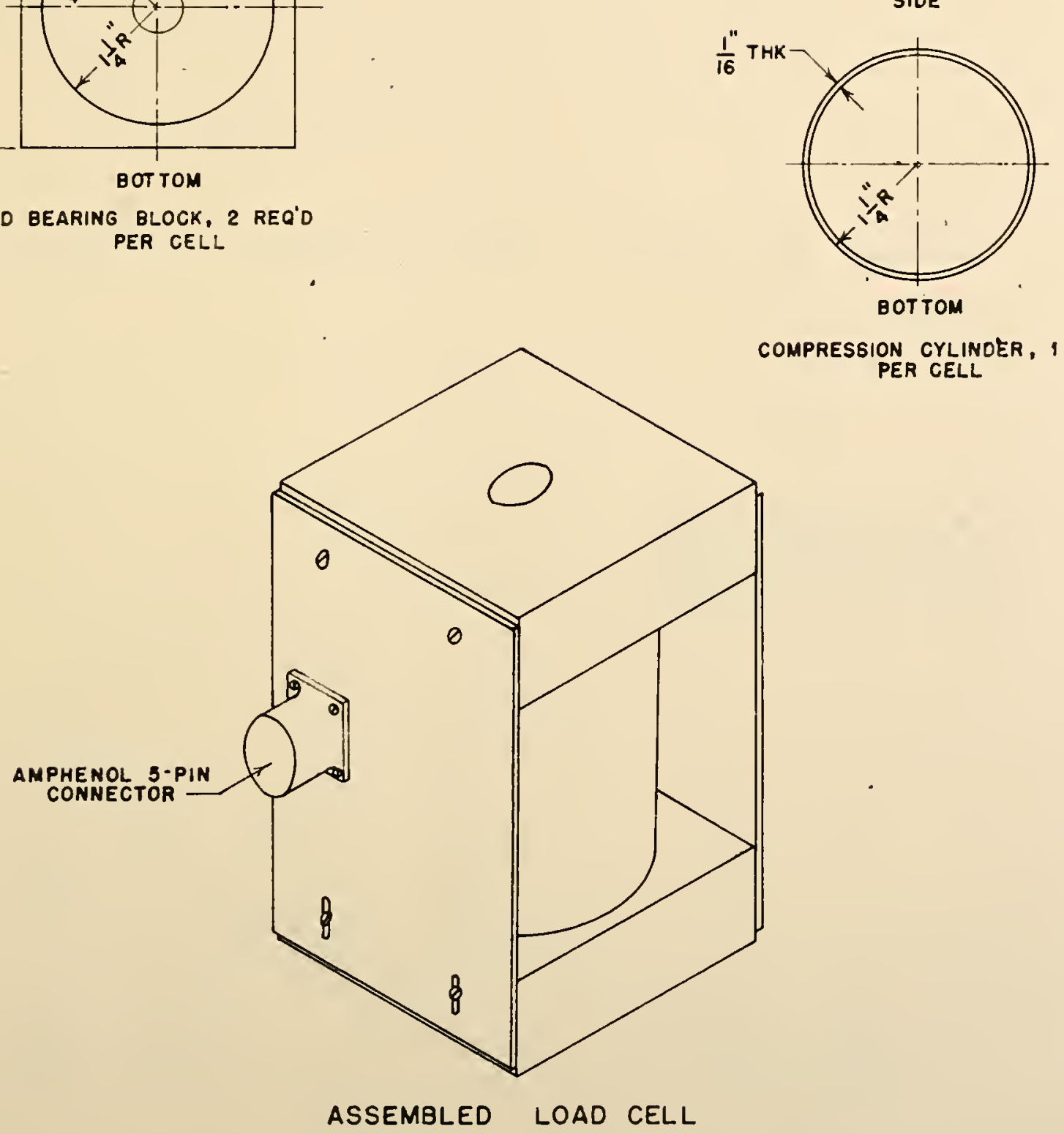

COMPRESBION CYLINOER, 1 PER CELL

FIGURE 36. CABLE-TENSION LOAD CELL DETAIL 


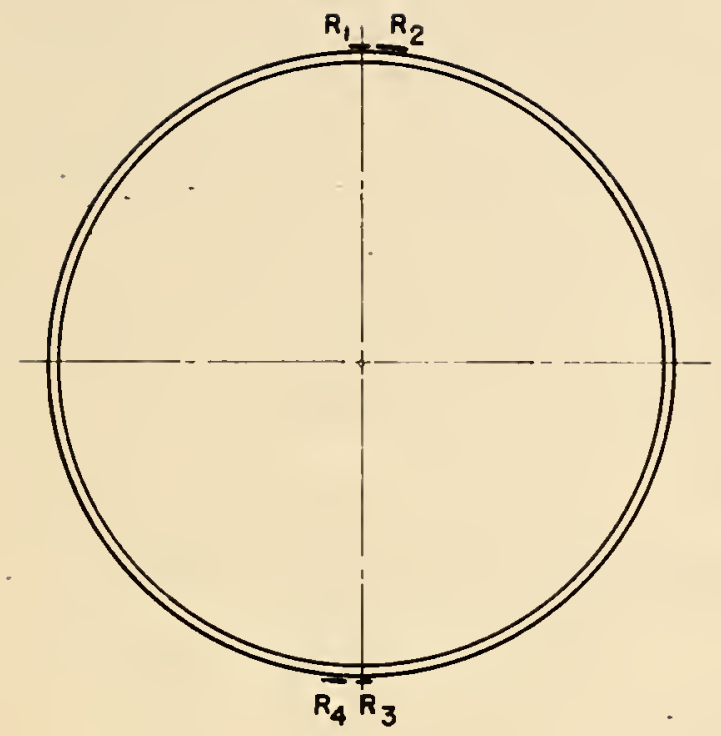

I. GAGES $R_{1}$ AND $R_{3}$ MEASURE LONGITUDINAL STRAINS.

2. GAGES $R_{2}$ ANO $R_{4}$ MEASURE HOOP STRAINS.

3. GAGE GRIDS ARE EQUIOISTANT FROM THE CYLINDER ENDS ANO ARE DIAMETRICALLY OPPOSED .

4. GAGES $R_{1}$ ANO $R_{2}, R_{3}$ AND $R_{4}$. ARE ON A COMMON BACKING AND ARE NOR.

MALLY ORIENTED ON THAT BACKING .

TOP VIEW OF COMPRESSION CYLINDER SHOWING GAGE LOCATIONS

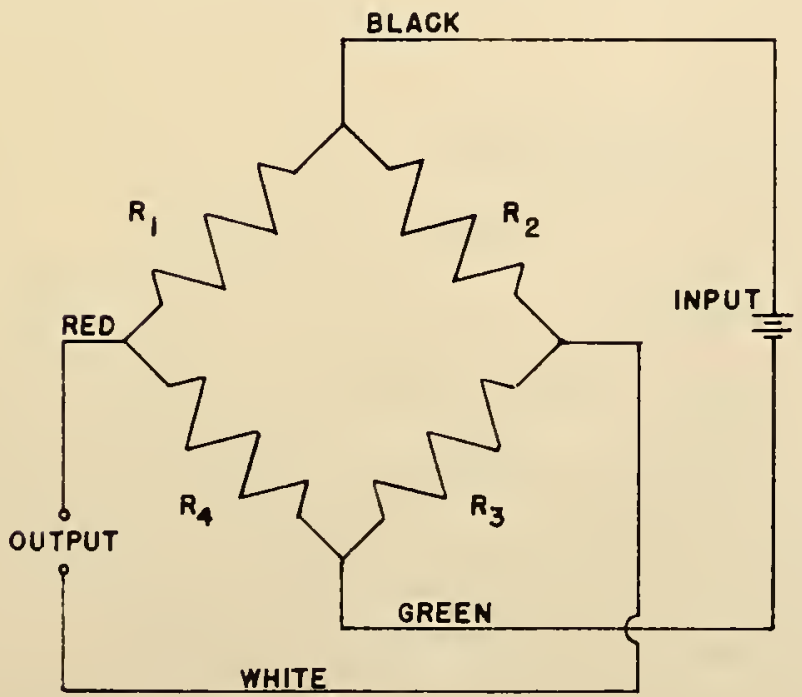

1. GAge REsistances ARE 350 oHMS

2. COLOR NAMES REFER TO WIRE USED IN ACTUAL CIRCUIT.

3. GAGES USED ARE MICRO-MEASUREMENTS (T.M.) TYPE $250 \mathrm{BB}$.

BRIDGE CIRCUIT USED FOR LOAD CELL STRAIN GAGES 
evident throughout the recomended 10,000 pound range. The maximum load which could be carried by the cell is 15,500 pounds. whereupon the cell would fail by local buckling.

The three cable tension load cells were calibrated using two cycles of loading and unloading with readings made at every 500 pounds. Prior to calibration, the cells were loaded several times to the 10,000 pound maximum load in order to assure proper seating of the parts of the cells during the calibration mms, for which Tables 5, 6, and 7 contain the calibration data.

Load Measuring Cell. The calibration curve for the 50,000 pound load cell which was used to measure applied loads during the static portion of the testing appears as Figure 4l. Design and calibration were performed by Mr.K. E. Whehr, a previous laboratory investigator. The curve appears as an aid to the reader who wishes to interpret the data which are presented.

\section{Iongitudinal Forces on Deck}

The AASHO code specifies in section 1.2.13 that "provision shall be made for the effect of a longitudinal force of five percent of the live load in all lanes carryling traffic headed in the same direction... the load used, without impact, shall be the lane load plus the concentrated load for moment specified in article 1.2.8."

The live load specified as the AASIIO lane load for HS 20-4h loading is 640 pounds per. lineal foot plus an 18,000 pound concentrated load. The deck wiath used in the experimental investigation was 10 feet or one lane width. The total lane load on the 10 foot wlde by 12 foot long section used for the experimental investigation would be 


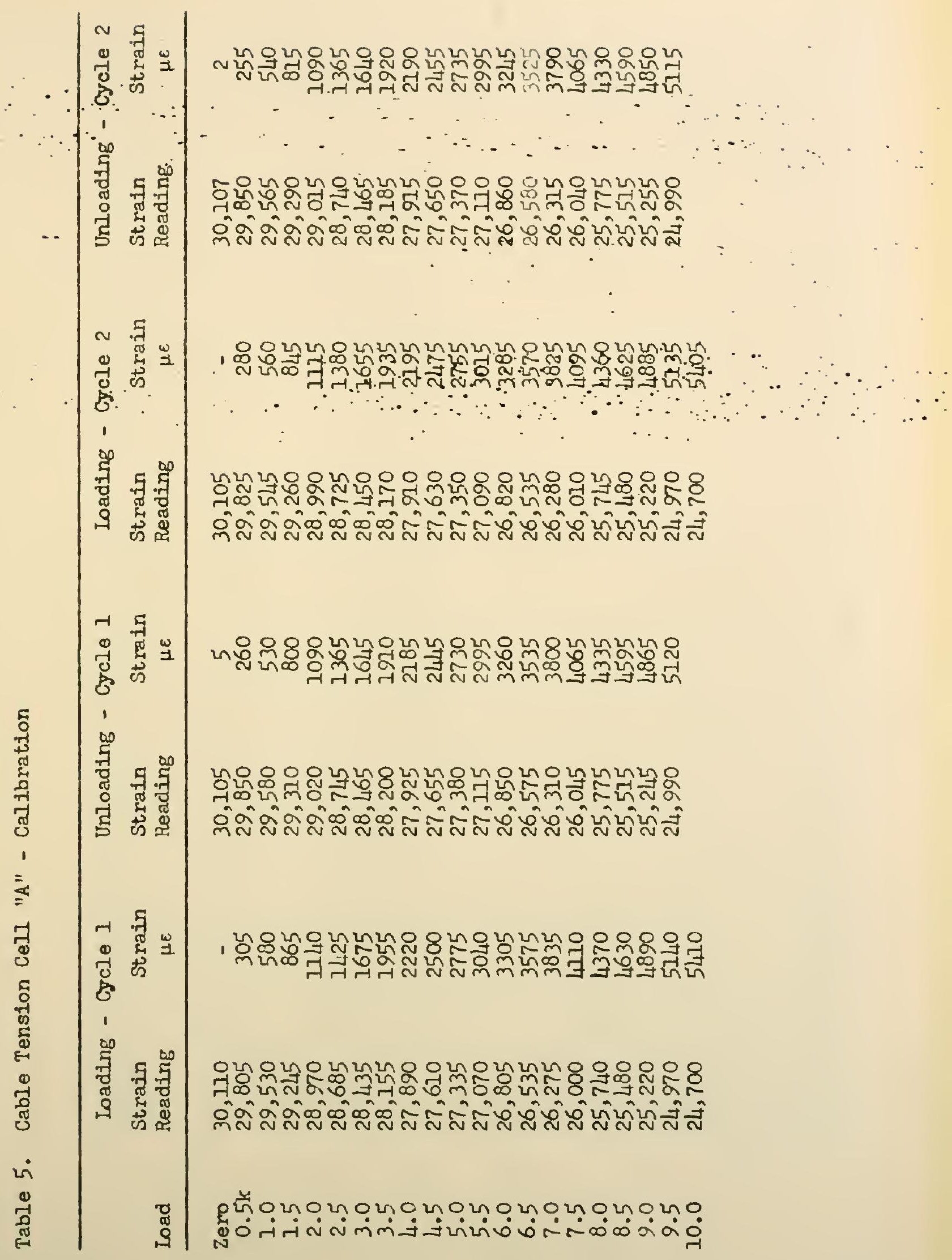




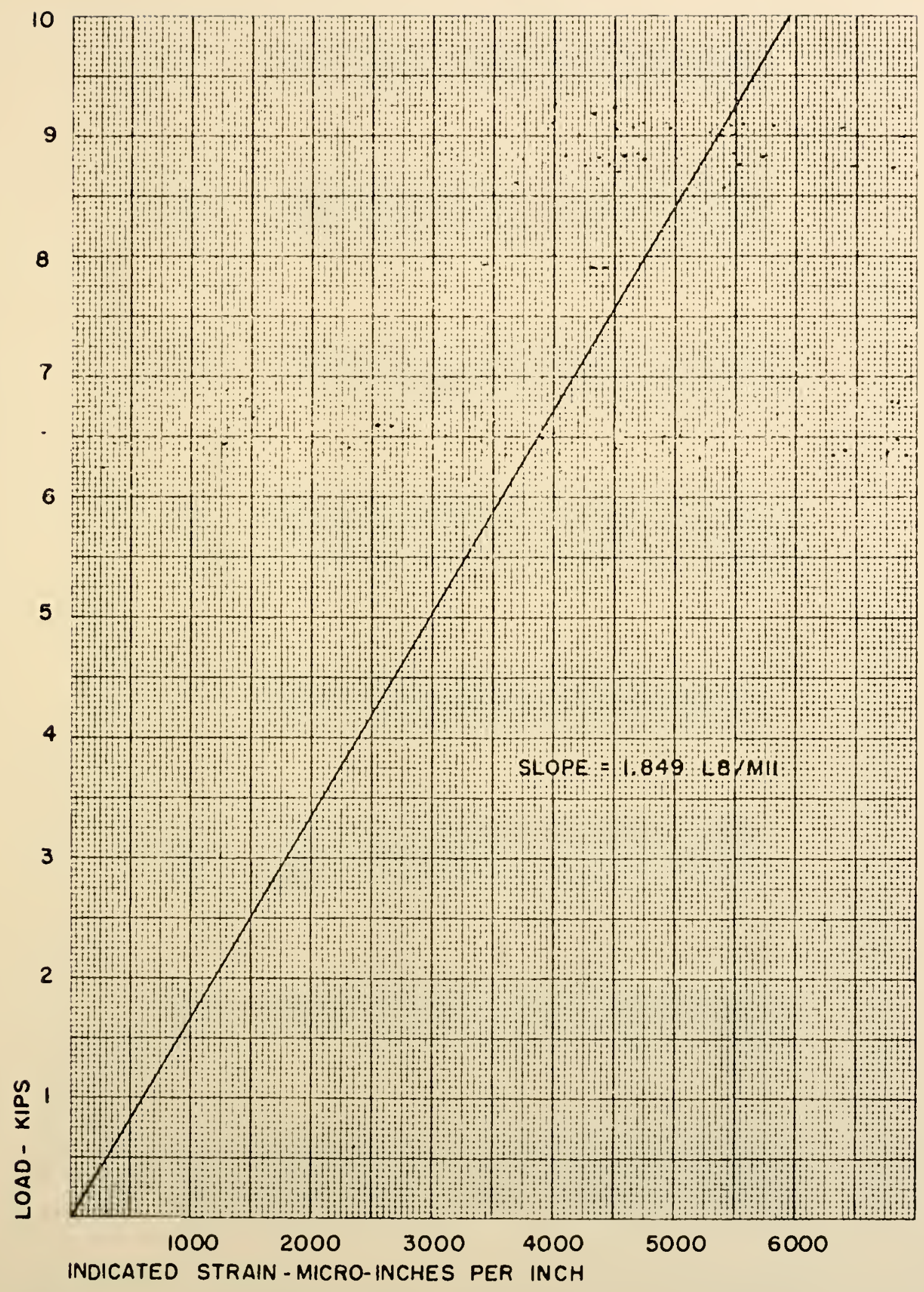

FIGURE 38. CALIBRATION CURVE, LOAD CELL A 


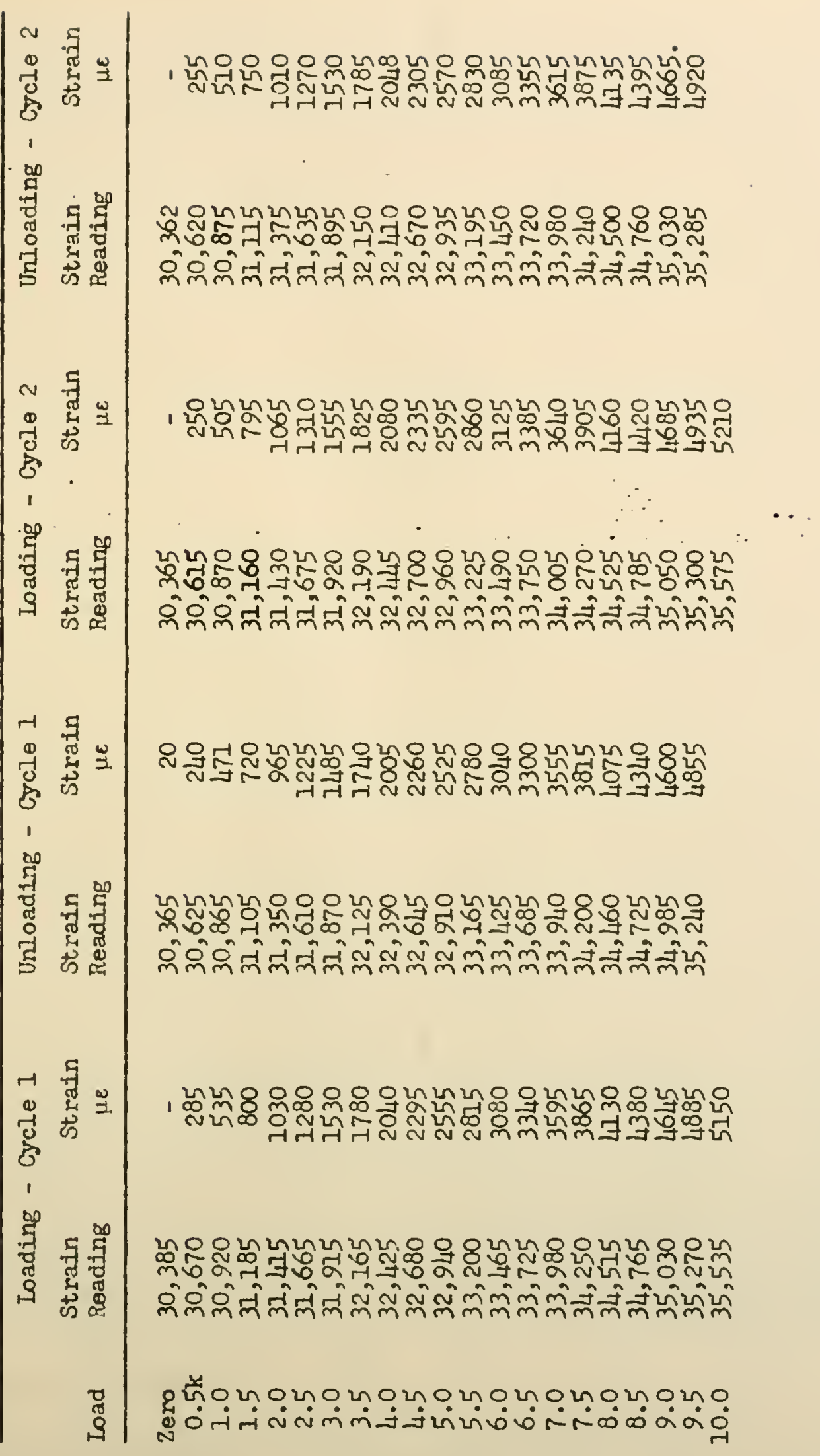




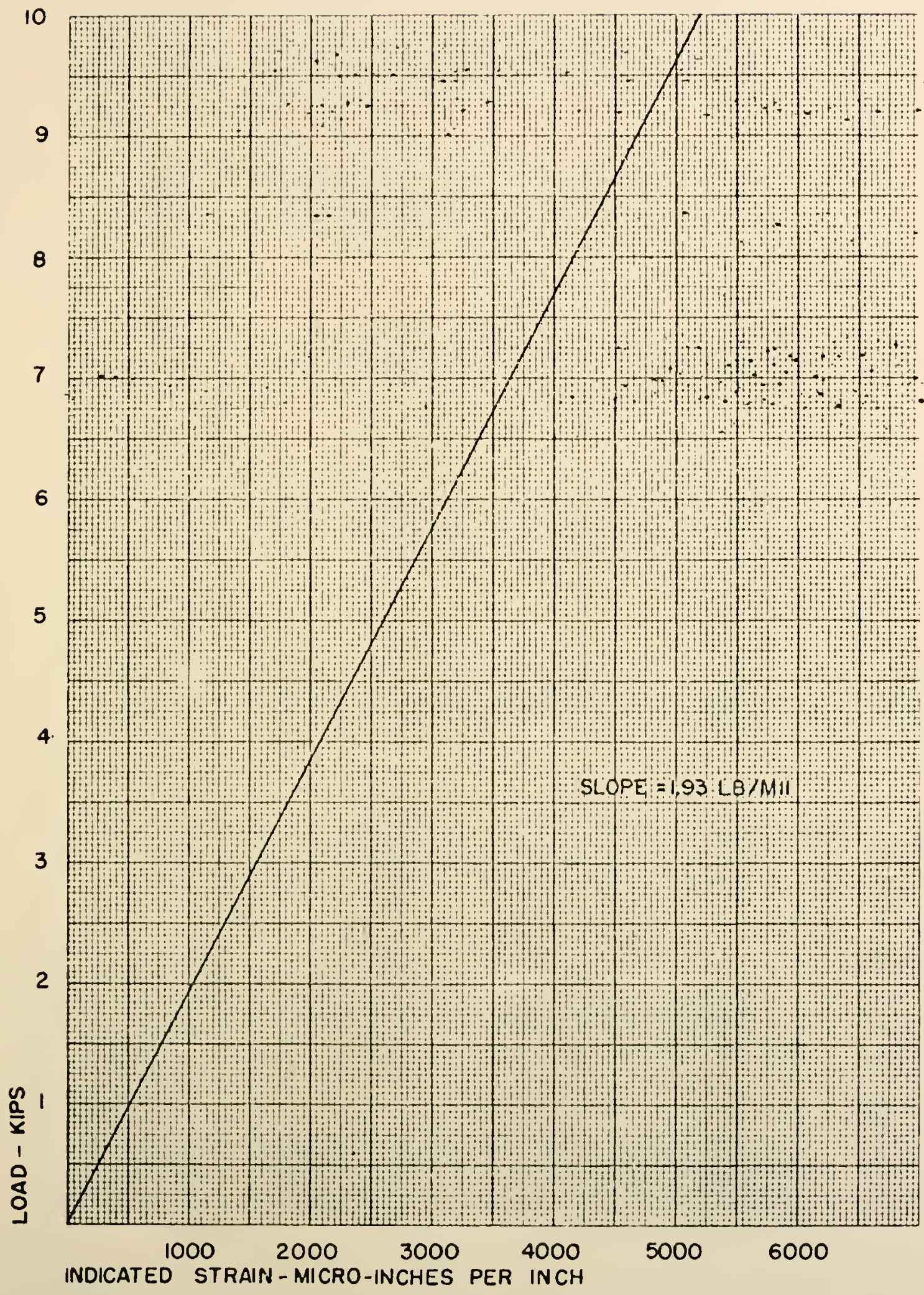

FIGURE 39. CALIBRATION CURVE, LOAD CELL B 


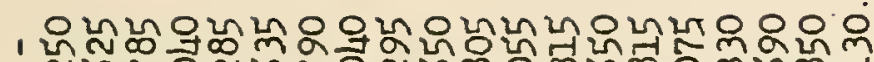

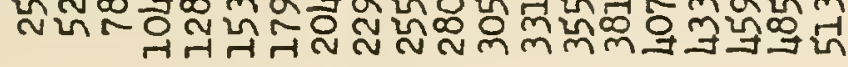

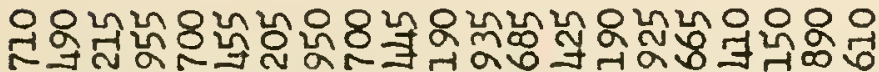

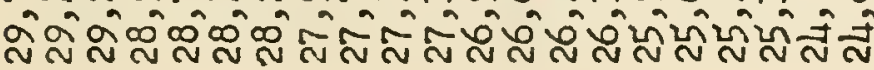

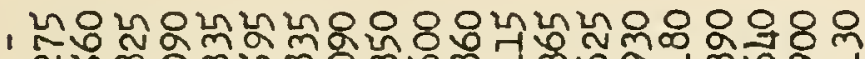
N

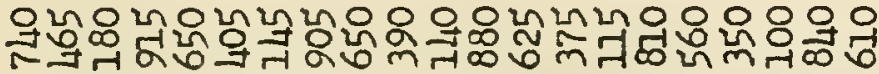

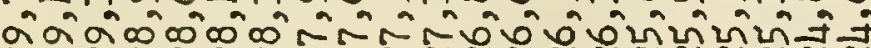
กิำกั

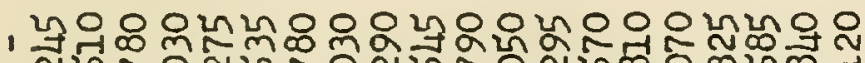

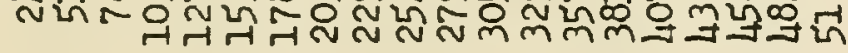

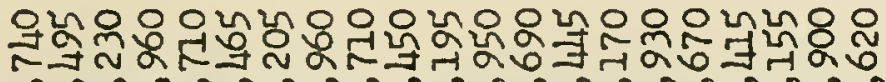

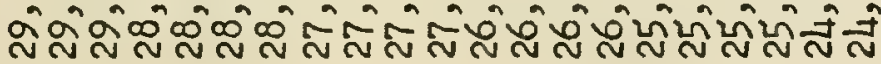

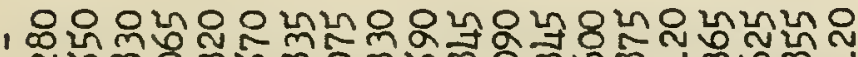

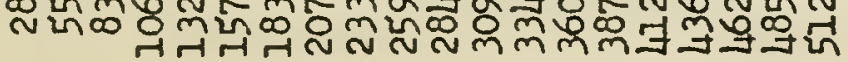

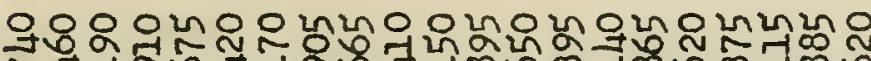

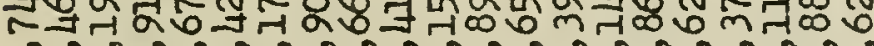

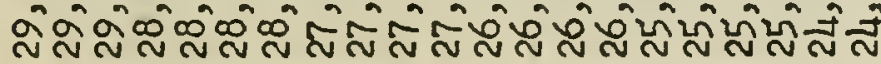

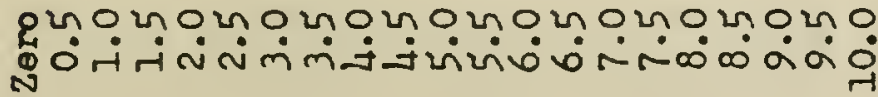




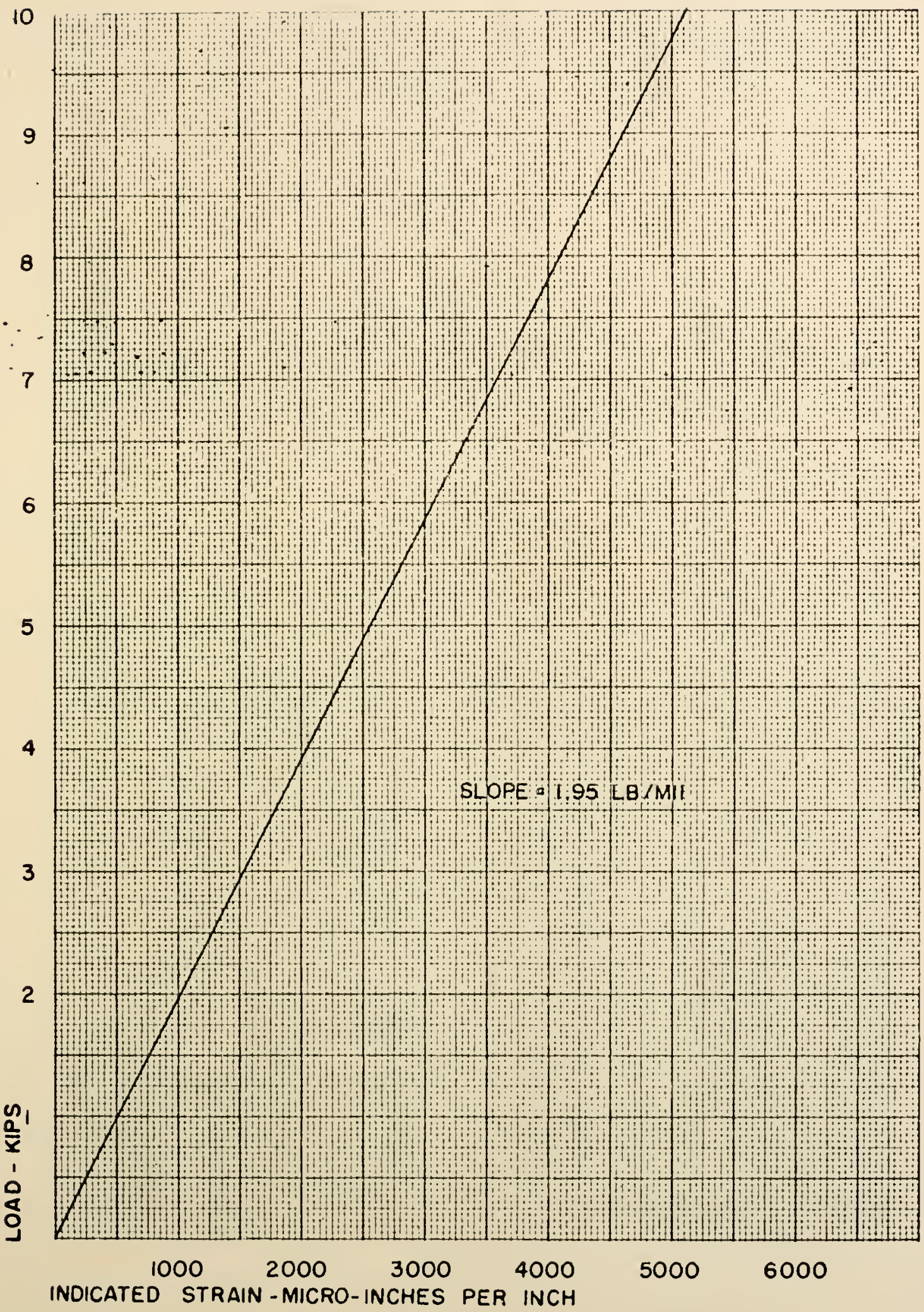

FIGURE 40. CALIBRATION CURVE, LOAD CELL C 


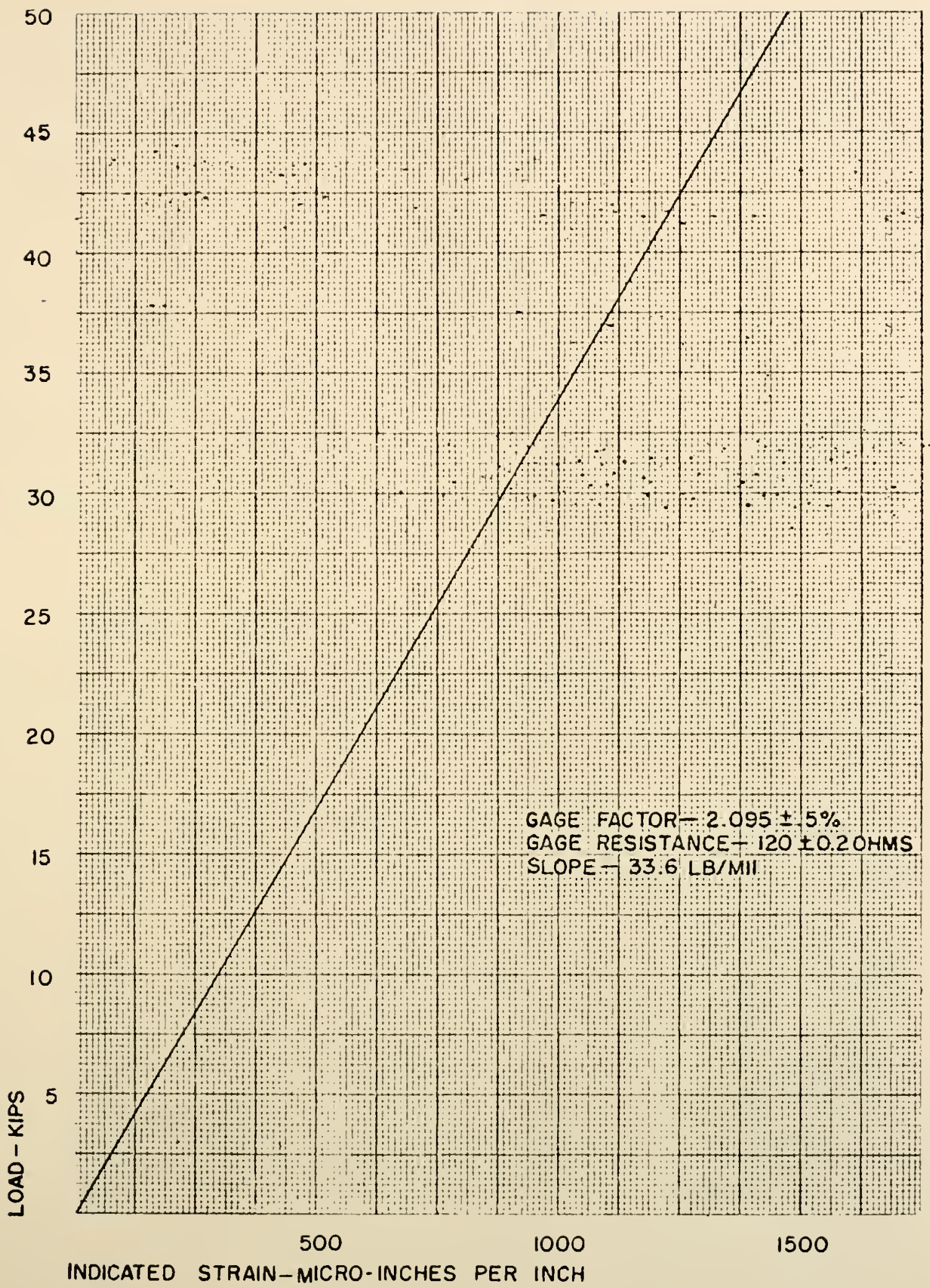

FIGURE 41. CALIBRATION CURVE, 50 KIP LOAD CELL 
$18+0.64(12)=25.68 \mathrm{kps}$. Taking five percent of this load as the longltudinal force to be resisted, the force to be transmitted from the deck to the supporting girders is 1,284 pounds on the experimental section.

Description of Test for Reststance to Horizontal Load

A 10 foot wide by 12 foot long deck section made up of four 3 foot by 10 foot sections was used for the hordzontal silp test. The test sas made up three serles which varied with regard to support condittons. Support was provided by 18 WF 70 lb beams. The testing: arrangement for the three series of tests are shown in Figures 44 and 45.

Series I. In Series I, support for the slab was provided by three 18 WF 70 Ib. beams spaced at $4^{\prime}-0 "$ center to center of web. The top Danges of the beams were leveled prior to the test by grout which was placed under the bottom flanges of the beams. The surface of the beams had been painted with a rust-proofing primer. The conditions approximated the conditions existing in a bridge which had a level floor system (or the case in whtch the floor system was not level and the Irregular vold space had been filled wi th a levoling course which was bonded to the deck slab but was not bonded to the floor system). The jacking system was arranged as shown in Flgure 4h. The load supplied to the deck was continuously monitored by means of a $50 \mathrm{kip}$ capacity (See calibration curve, Figure LI) load cell which was coupled to a siftch and balance unit and a strain indicator. The only motion in the system was between the deck and its supporting beams since the supporting beans were prevented from moving by a restraining beam resting on 
the floor, oriented normal to the supporting beams. The restraining beam was held motionless by braces inserted into shear plugs in the laboratory floor. A post-tensioning force was maintained in the two outermost cables in order to close the joints and to ensure that the entire deck moved at flrst slippage. The cable tension load cells were also connected to the previously mentioned switch and balance unft and strain indicator.

The bolting force in the hold-down clip system was varied by not. only changing the number of bolts but also by varylng the applied torque in each bolt. The pettern of bolting systems was also varied in Series I. The bolting arrangenents referred to in Table 8 are illustrated in Flgures $\$ 2$ and 43.

Series II. In Series II, support for the slab was provided by three 18 WF $70 \mathrm{Ib}$. beams spaced at 4'-0" center to center of web but the grout used to level the Serles I beams had been removed, making the slab support uneven and the bsaring area variable. In Series II, the condition of an non-level floor system without a leveling course was approximated. All other conditions of load monitoring, facking, and support were the same in Series II as in Series I. The bolting arrangement indicated in Table 8 is 1llustrated in Flgures 42 and 43.

Series III. In Series III, support for the deck was provided by two 18 WF 70 Ib. beams at $8{ }^{\prime}-0^{\prime \prime}$ center to center of web. The beams were supported off the laboratory floor at their ends by one-half inch steel bar stock. The support for the slab was uneven and the bearing area botween the deck and beams was variable. The jacking beam in this case was restrained by another restraining beam, held by oupports installed 


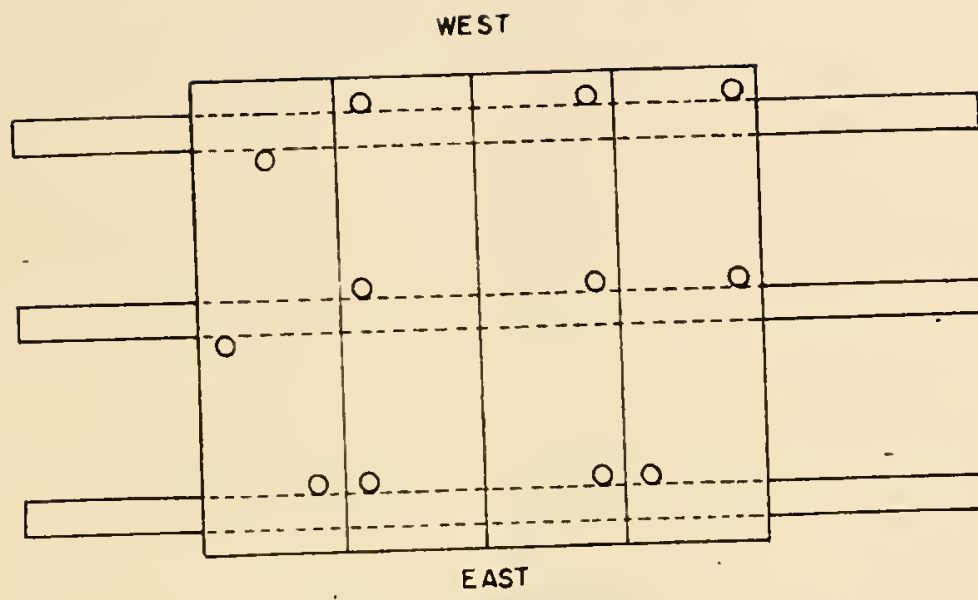

BOLTING ARRANGEMENT I

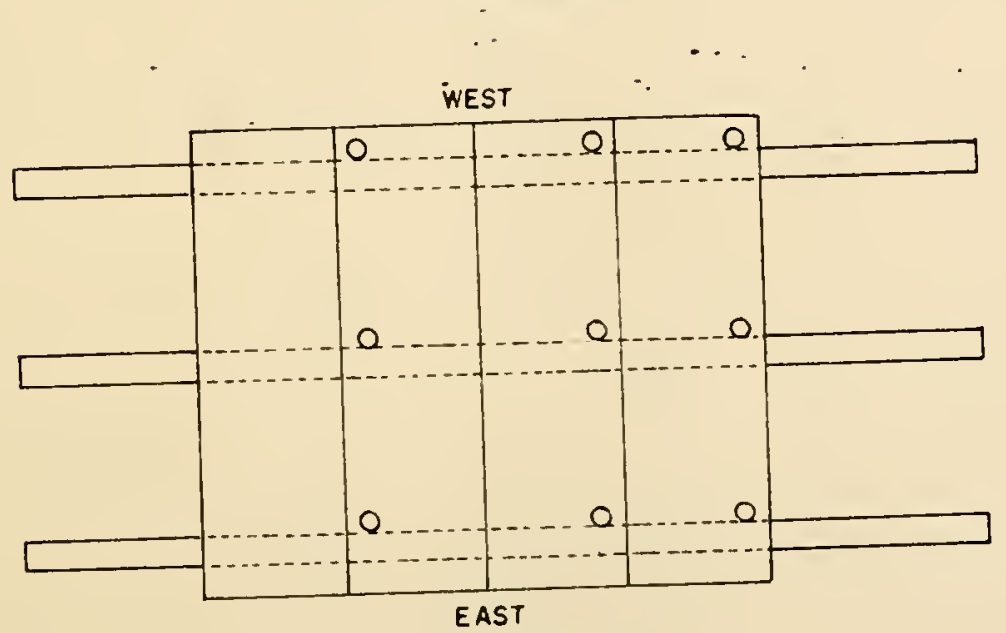

BOLTING ARRANGEMENT 2

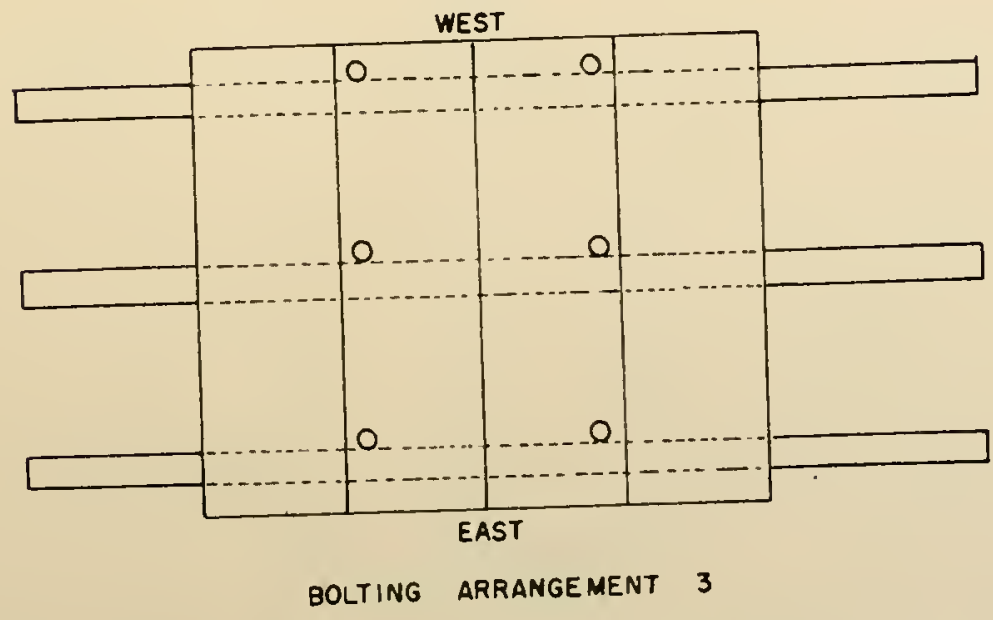

FIGURE 42 . LONGITUDINAL SLIP TEST, BOLTING ARRANGEMENTS $1,2,3$ 


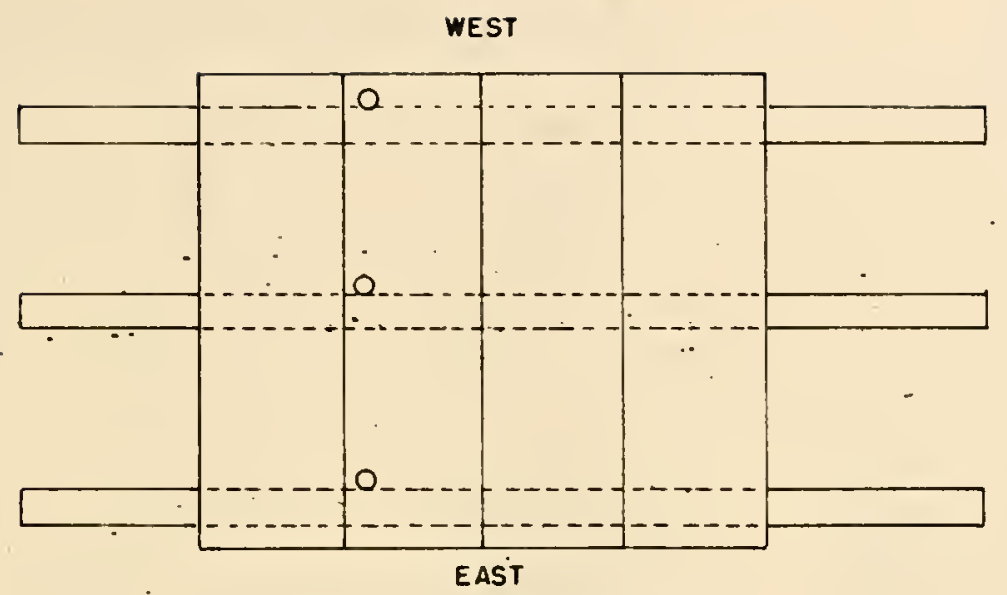

BOLTING ARRANGEMENT 4
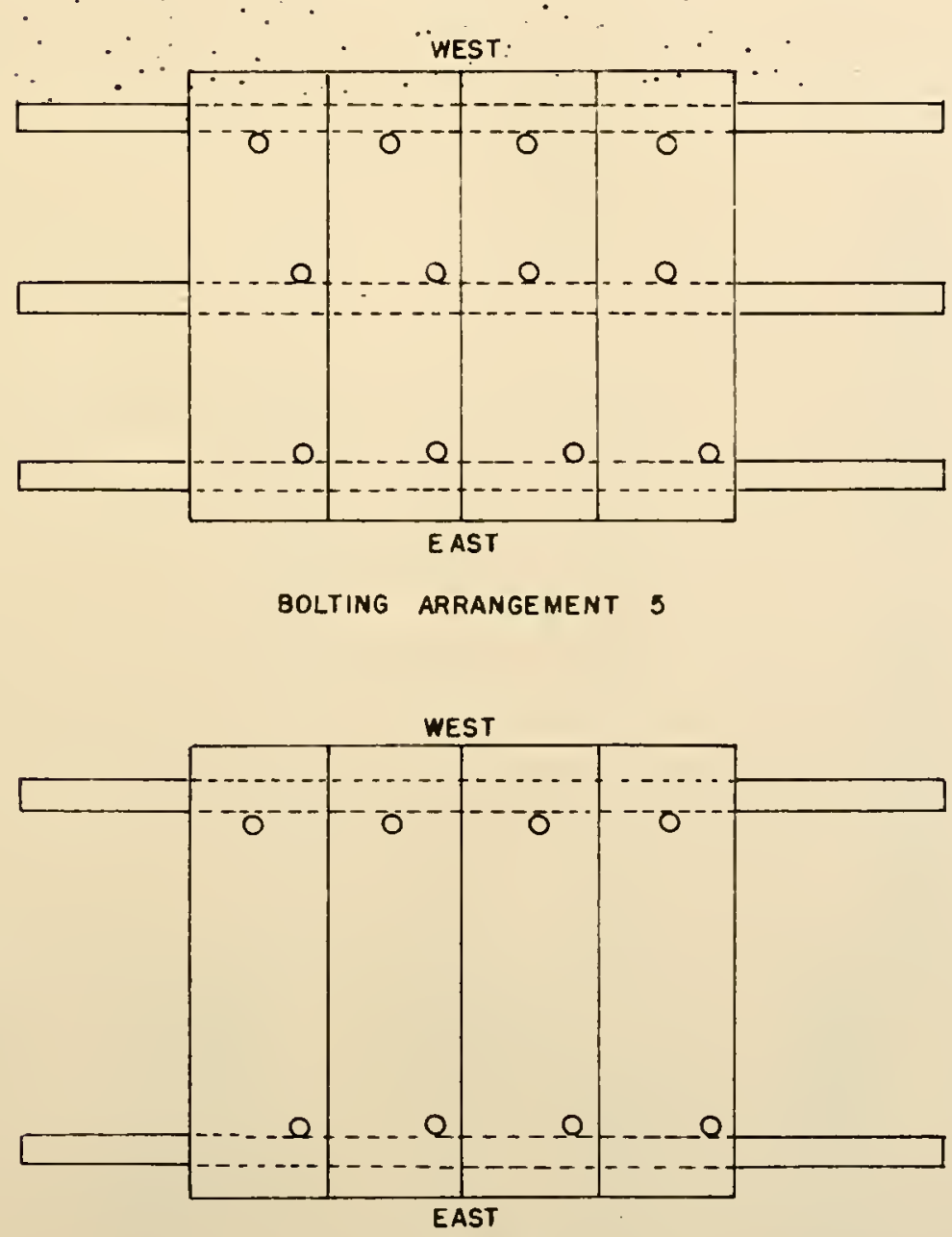

BOLTING ARRANGEMENT 6

FIGURE 43. LONGITUDINAL SLIP TEST, BOLTING ARRANGEMENTS 4,5,6 


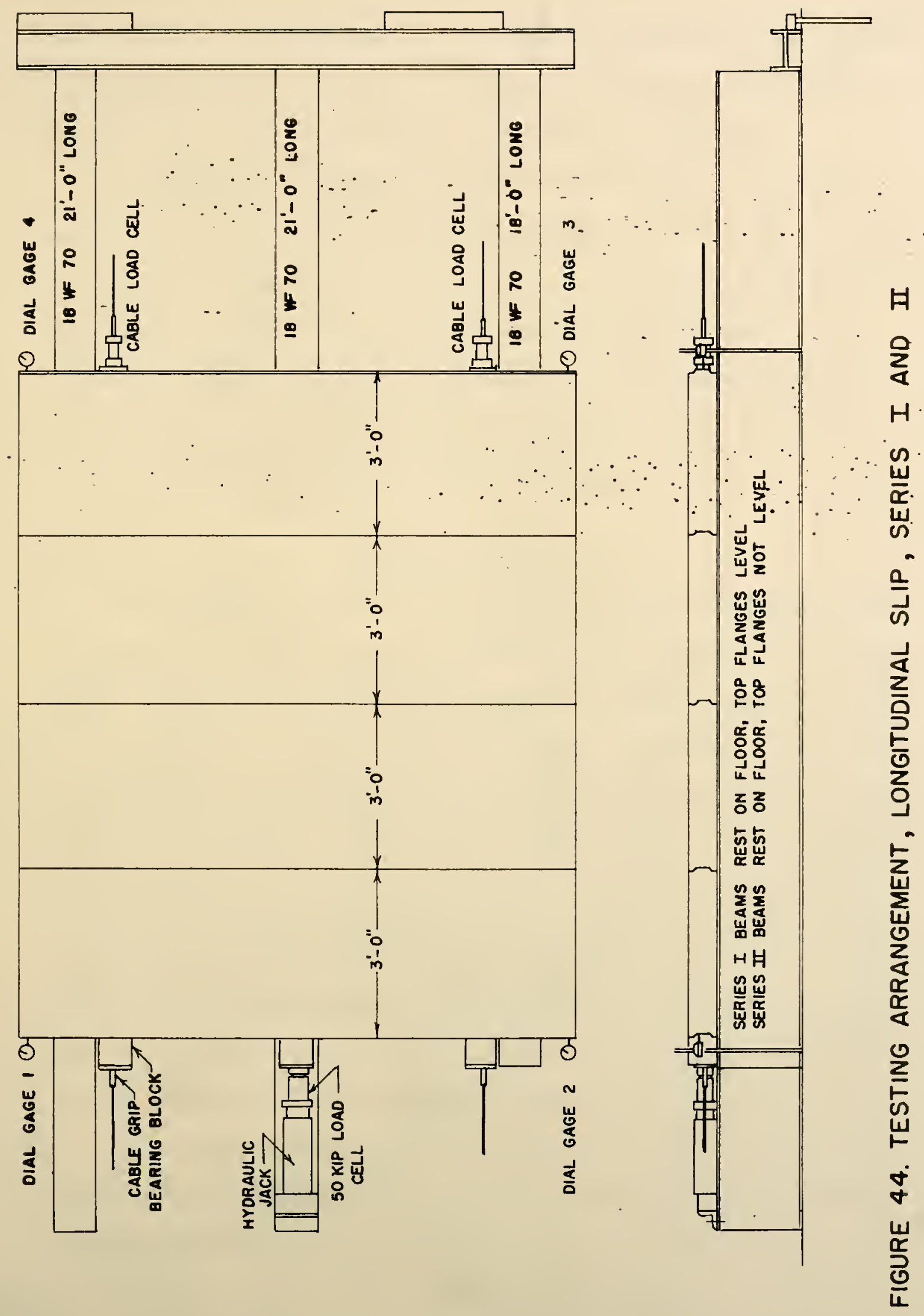


in the floor of the laboratory. The jacking beam remained on the laboratory floor and the fack and load cell were raised in order to apply the horizontal load at mid depth of the deck. See Flgure 45 .

Measurement of Morement. The motion of the deck system was measured by four .001 inch dial gages placed at the four extreme corners of the section at mid depth of the deck. Longltudinal motion was measured at each point after each increase in applied load. The occurrence of slip was noted not only by the dial gages but also in the inability of the deck to resist an increase in load as noted by the strain indicator coupled to the load cell.

\section{Results of Slip Test}

The results of the 8lip test appear as Table 8 and graphlcally as Figure 46. In all cases, the horizontal load resistance of the deck system exceeds the AASHO code requirement of 1,284 pounds for the deck section analyzed. In all cases, an increase in bolting force produced an increase in horizontal resistance with the most pronounced increase occurring in Series I, the case of level beam flanges. For this reason, beam flanges which are nearly level or are essentially level due to the placement of a filler between the beams and slab would offer the greatest resistance to horizontal motion in a bridge. Although bolting was done on only one eide of the beam flange, the bolting could be accomplishod on both sides of the supporting beam if desired.

The bolting force predicted will not be realized if the bolts have not been lubricated; lubrlcation 18 always recommended before tightening the bolts. 

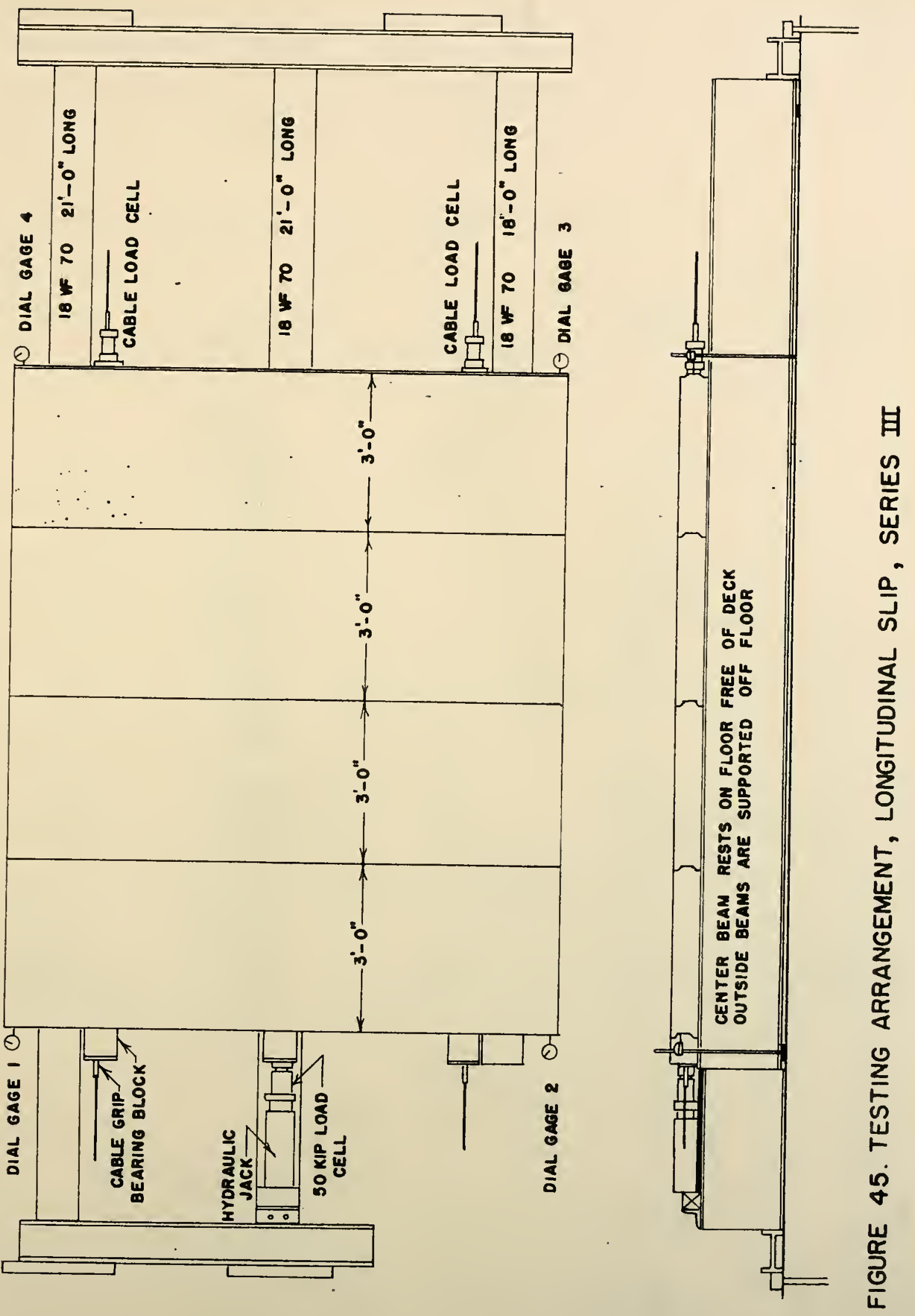
Table 8. Resistance of Deck to Longt tudinal Forces

\begin{tabular}{|c|c|c|c|c|}
\hline Series & $\begin{array}{l}\text { Horizontal Load } \\
\text { at Slip lb }\end{array}$ & $\begin{array}{c}\text { Bolting } \\
\text { Arrangement }\end{array}$ & $\begin{array}{l}\text { Bolting } \\
\text { Force Ib }\end{array}$ & $\begin{array}{l}\text { Number of } \\
\text { Bolts }\end{array}$ \\
\hline$I$ & 4,502 & - & 0 & 0 \\
\hline I & 4,502 & $\therefore$ & 0 & 0 \\
\hline I. & $8,064$. & 1 & 24,000 & 12 \\
\hline $\bar{I}$ & 17,760 & 1 & 48,000 & 12 \\
\hline I. & 12,096 & 1 . & 48,000 & 12 \\
\hline I & 12,230 & 1 & 48,000 & 12 \\
\hline$I$ & 11,256 & 2 & 36,000 & 9 \\
\hline I & 10,450 & 2 & 36,000 & 9 \\
\hline I & 10,080 & 3 & 24,000 & 6 \\
\hline I & 10,248 & 3 & $24, \infty 00$ & 6 \\
\hline I & 7,392 & 4 & 12,000 & 3 \\
\hline I & 7,896 & 4 & 12,000 & 3 \\
\hline I & 2,822 & $\overrightarrow{-}$ & 0 & 0 \\
\hline$I$ & 3,763 & - & 0 & 0 \\
\hline II & 3,220 & - & 0 & 0 \\
\hline II & 3,260 & - & 0 & 0 \\
\hline II & 5,380 & 5 & 24,000 & 12 \\
\hline II & 5,380 & 5 & 24,000 & 12 \\
\hline II & 6,320 & 5 & 48,000 & 12 \\
\hline II & 6,600 & 5 & 48,000 & 12 \\
\hline III & 3,430 & - & 0 & 0 \\
\hline III & 3,360 & - & 0 & 0 \\
\hline III & 3,760 & 6 & 16,000 & 8 \\
\hline III & 3,830 & 6 & 16,000 & 8 \\
\hline III & 4,170 & 6 & 32,000 & 8 \\
\hline III & 4,200 & 6 & 32,000 & 8 \\
\hline
\end{tabular}




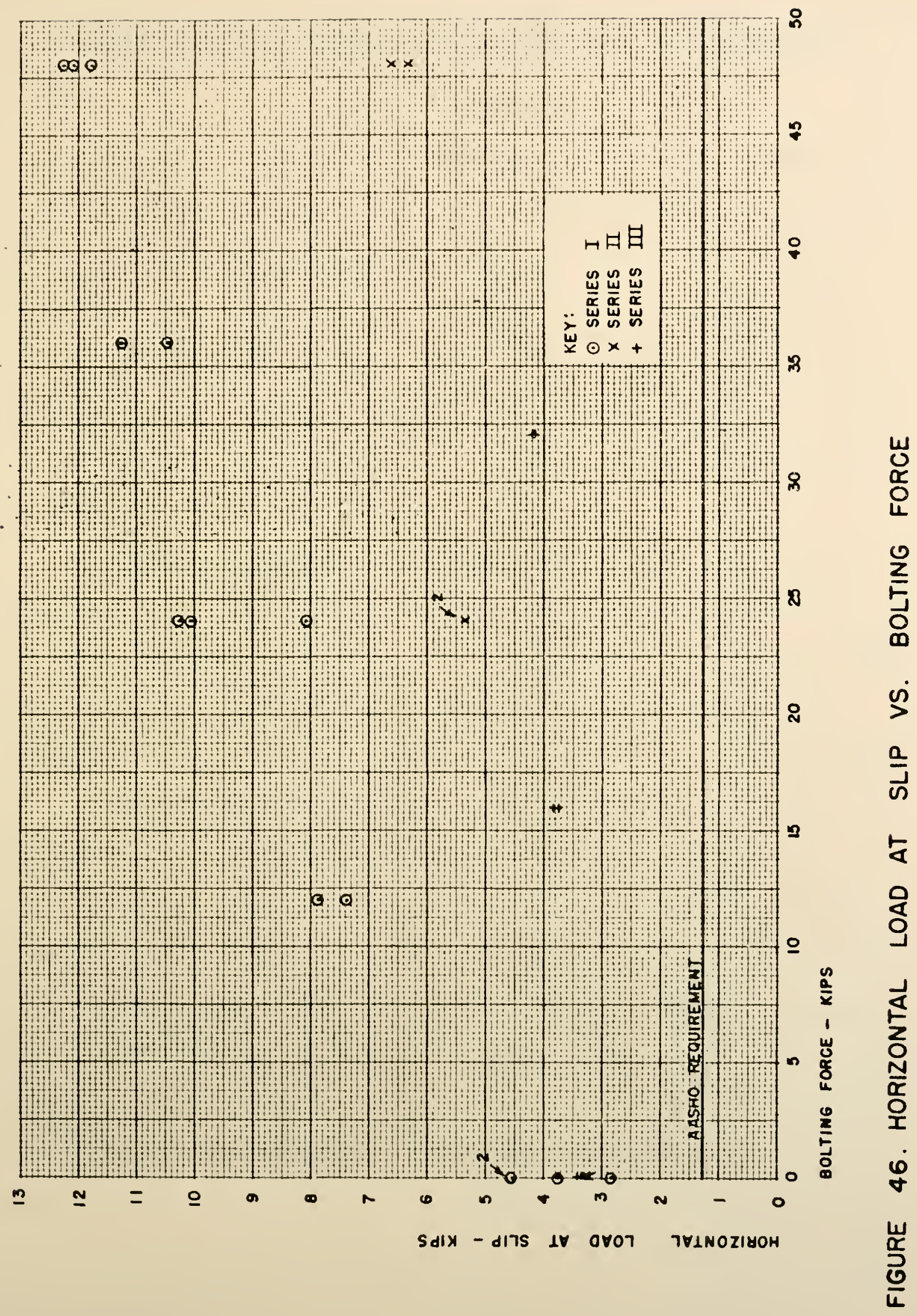




\section{Static Testing of Specimens Reinforced for 4'-0" Beam Spacing}

\section{Description of Test}

Figures 47 and 48 indlcate the testing arrangement used for the static test with 4'-0" beam spacing. The supporting beams, previously used in the longitudinal slip test, rested on the floor of the laboratory; grout was placed between the floor and the bottom flanges in order to level the top- Ilanges far the test. Ioad was applied at mldspan of the slab with a hand-operated hydraulic jack through a 10 inch diameter steel plate and rubber pad. Prfor to any loading the joints were closed.

Measurement of Loads. A constant monttor of applied load was made with the $50 \mathrm{kip}$ load cell connected to a switch and balance unit and strain indicator. The same switch and balance unit and strain indicator were used to monttor the cable tension load cells without any adjustment ofnce gage factors for the several load cells were identical.

Measurement of Deflection. Deflection points on the slab consisted of quarter-Inch hardwood dowel pegs cemented to the concrete with Daco (T.M.) Cement. A 0.10 inch gradustod rod was held on these pegs and read with a self-leveling level fltted with an optical vemier, permitting deflection measurements to 0.001 inch. Polnts where deflectIon measurements were made are 11lustrated in FIgure 49. Before and after each serfes of readings, the elevation of a flxed point was taken and compared to the elevation whlch had been observed at the start of the test to ensure that the level had not moved durfing the test. Whth no load at the beginning of each load stage the elevation of each point was read and subsequent readings were made after a change in applied 


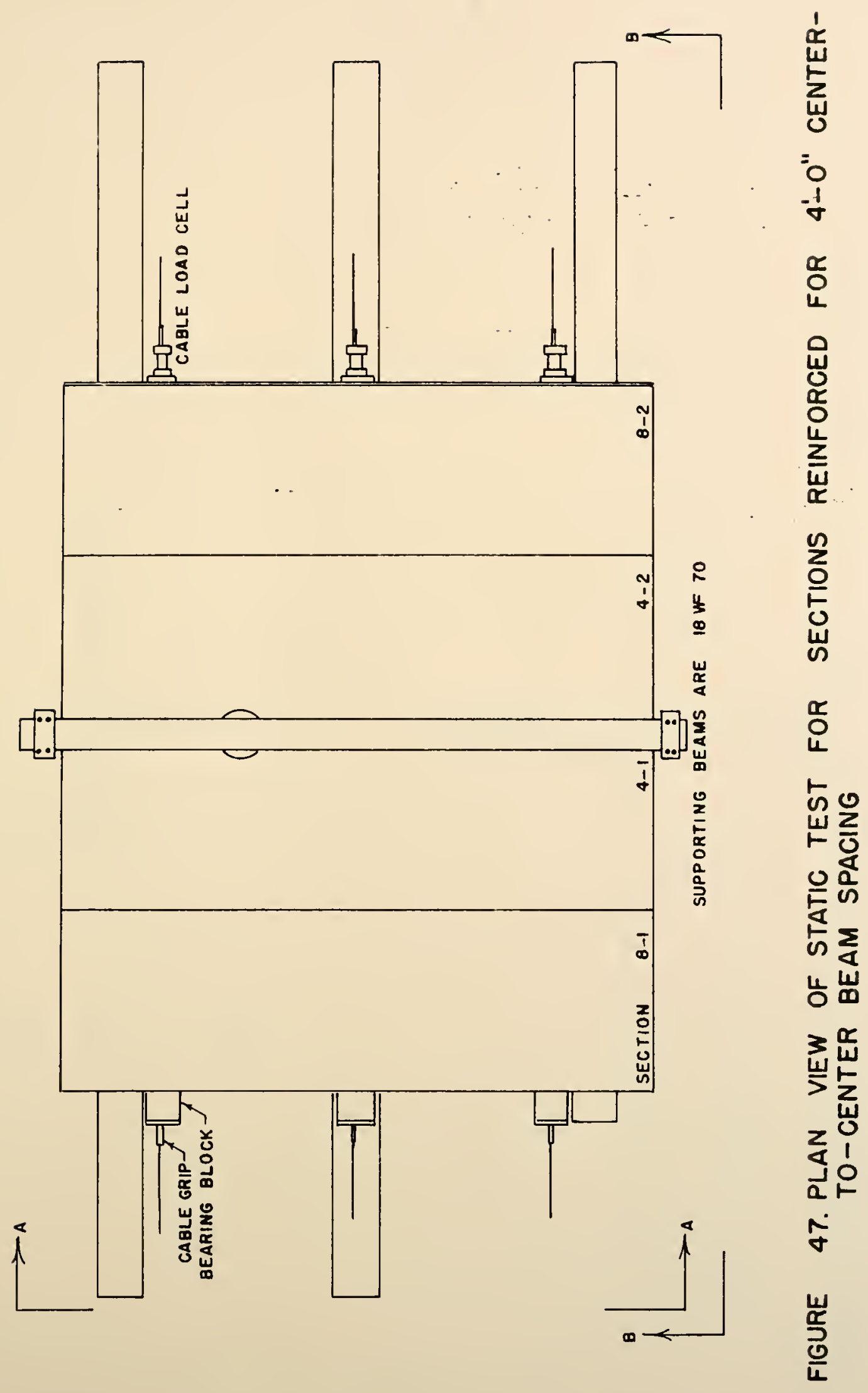



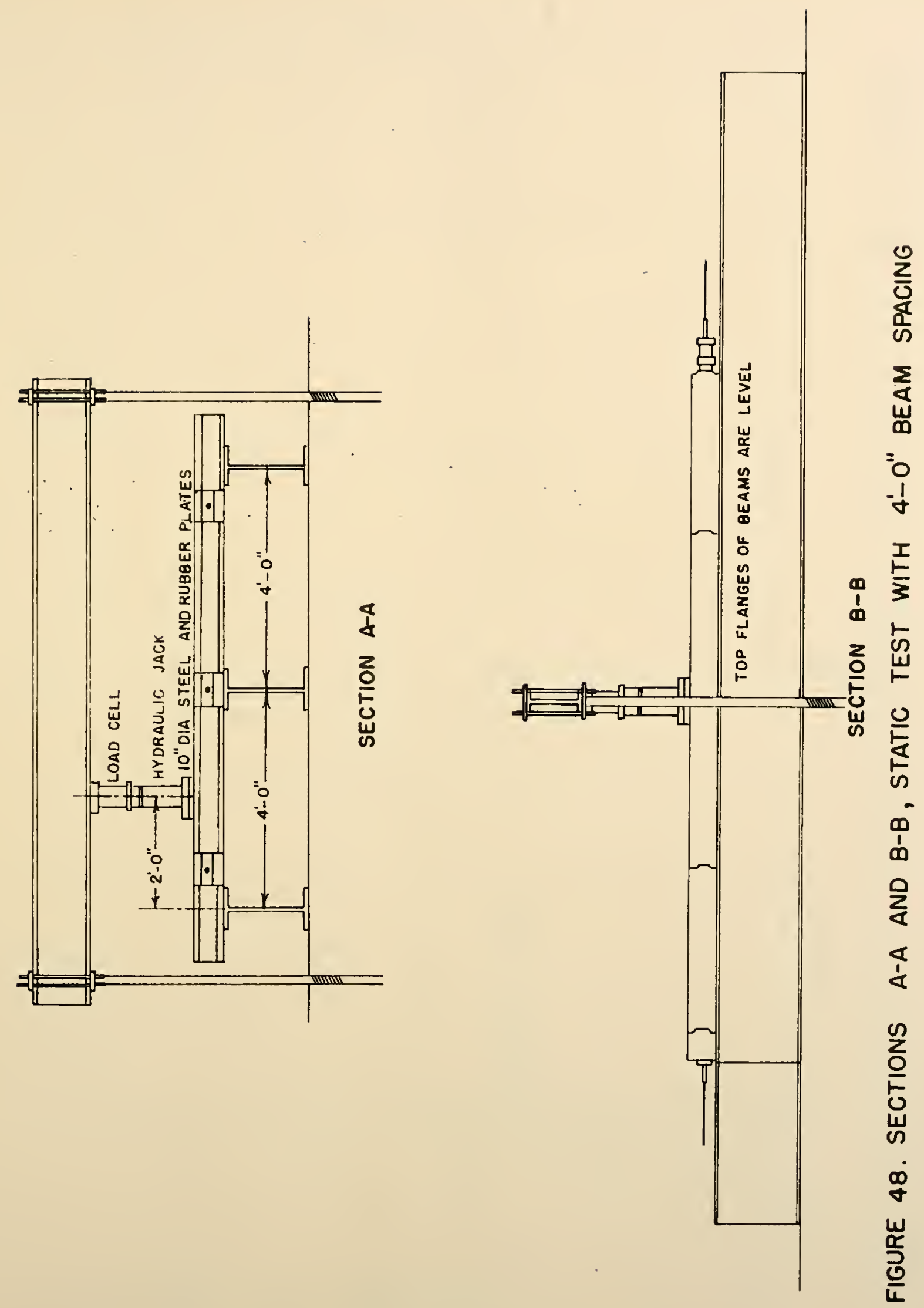


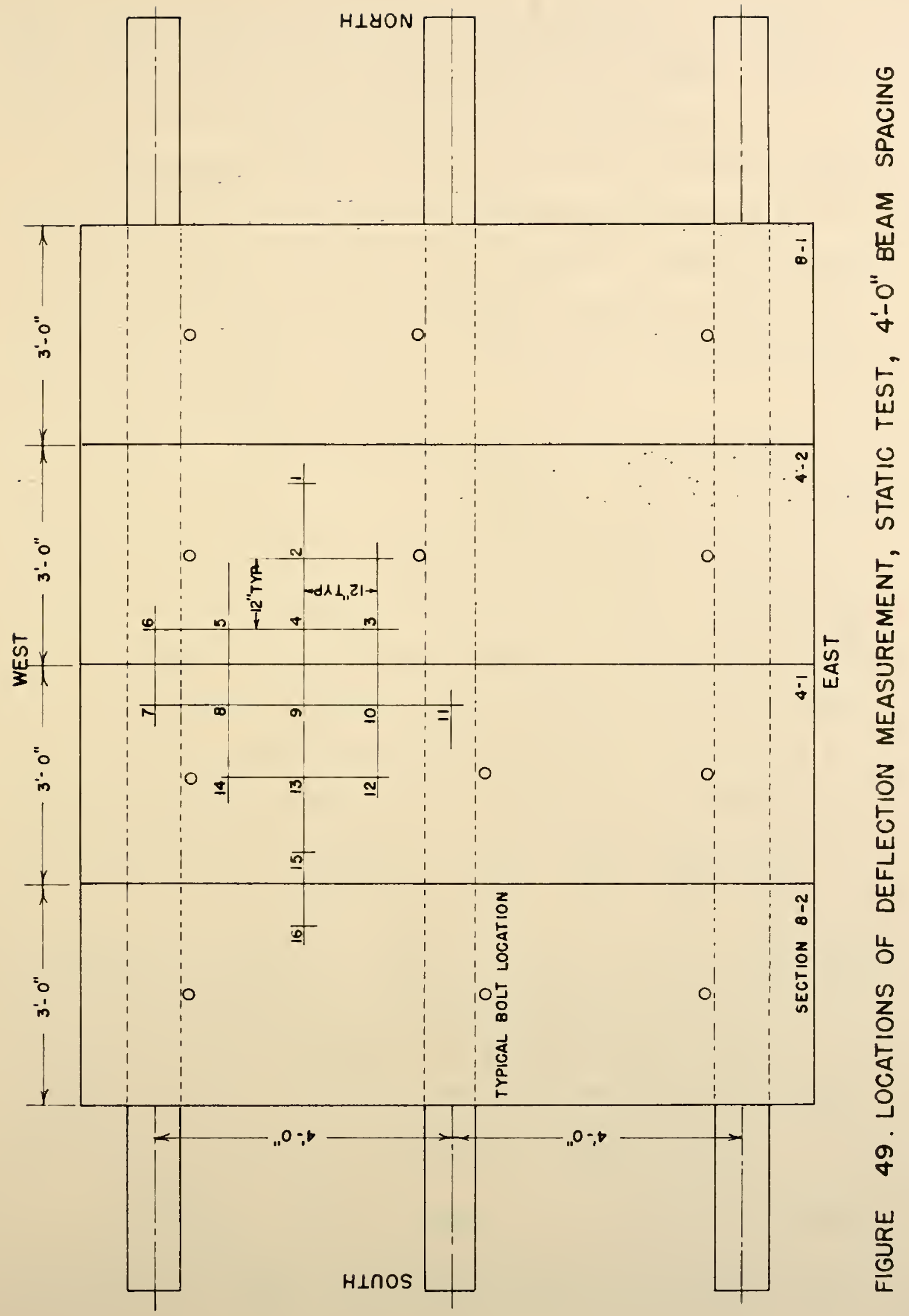


load. The difference between the orlginal reading and the reading after load application gave the deflection due to loading. Flgures 50 iliu 55 contain deflection information as does $\mathrm{T}$ able $I I$.

Measurament of Strain. SR-4 (T.M.) electrical resistance strain gages were used in a bastc wheatstone bridge circuit with one active arm; attached to the other arms of the bridge were a compensating gage atteched to an unstressed concrete cylinder, and two precietion wirewound resistors. Nominal resistance for all gages was 120 ohms; gage factor for the gages was $2.04 \pm 1 \%$.

The straln was not measured directly due to the large number of gages and the relative slowness of the mothod compared to other methods available. The method used conslited of measuring the voltage across the basic Wheatstone bridge with a digital volt meter, a method wilch permits reading of a large nuber of gages in a short period of time.

A constant voltage power supply was used to power the circust and the applied voltage was maintained at 4 volts. The choice of 4 volts was made after examination of the equation for output in the Wheatstone bridge: $\quad E=\frac{\nabla R_{1} R_{2}}{\left(R_{1}+R_{2}\right)^{2}}\left(\frac{\Delta R_{1}}{R_{1}}-\frac{\Delta R_{2}}{R_{2}}+\frac{\Delta R_{3}}{R_{3}}-\frac{\Delta R_{4}}{R_{4}}\right)^{I}$.

In applying this equation to the circuit used, $\nabla$ is the 4 volts supplied, $R_{1}$ is the active gage, $R_{2}$ is the compensating gage, and $R_{3}$ and $R_{4}$ are preciston wire-wound resistore. All resistors in the circuit are nominally 120 ohms. The only resistance change occurred in $P_{1}$, the active gage, which reduces the expression for the output to:

$$
E=\frac{V R_{1} R_{2}}{\left(R_{1}+R_{2}\right)^{2}}\left(\frac{\Delta R_{1}}{R_{1}}\right) \text {. Since } R_{1}=R_{2} \text {, the expression further }
$$

reduces to $E=\frac{V}{4}\left(\frac{\Delta R_{1}}{R_{1}}\right)$. The strain causing the resistance change, 
Table 9. Load Stages Durlng Teating of Sections Relnforced for 4'-o" Beam Spacting

\begin{tabular}{cccc}
\hline $\begin{array}{c}\text { Load } \\
\text { Stage }\end{array}$ & $\begin{array}{c}\text { Post-Tensioning } \\
\text { (psi on gross section) }\end{array}$ & $\begin{array}{c}\text { Bolting Force } \\
\text { (kdps) }\end{array}$ & $\begin{array}{c}\text { Applied Load } \\
\text { (pounds) }\end{array}$ \\
\hline $1 . .0$ & 0 & 5,040 \\
& 0 & 0 & 10,080 \\
2 & 0 & 0 & 15,120 \\
& 20.2 & 0 & 5,040 \\
& 20.2 & 0 & 10,080 \\
3 & 20.2 & 0 & 15,120 \\
& 33.6 & 0 & 5,040 \\
& 33.6 & 0 & 10,080 \\
4 & 33.6 & 0 & 15,120 \\
& 33.6 & 48 & 5,040 \\
& 33.6 & 48 & 10,080 \\
5 & 33.6 & 48 & 15,120 \\
& 20.5 & 48 & 5,040 \\
& 20.6 & 48 & 10,080 \\
6 & 20.6 & 48 & 15,120 \\
& & 48 & 5,040 \\
& 0 & 48 & 10,080 \\
& 0 & 48 & 15,120
\end{tabular}



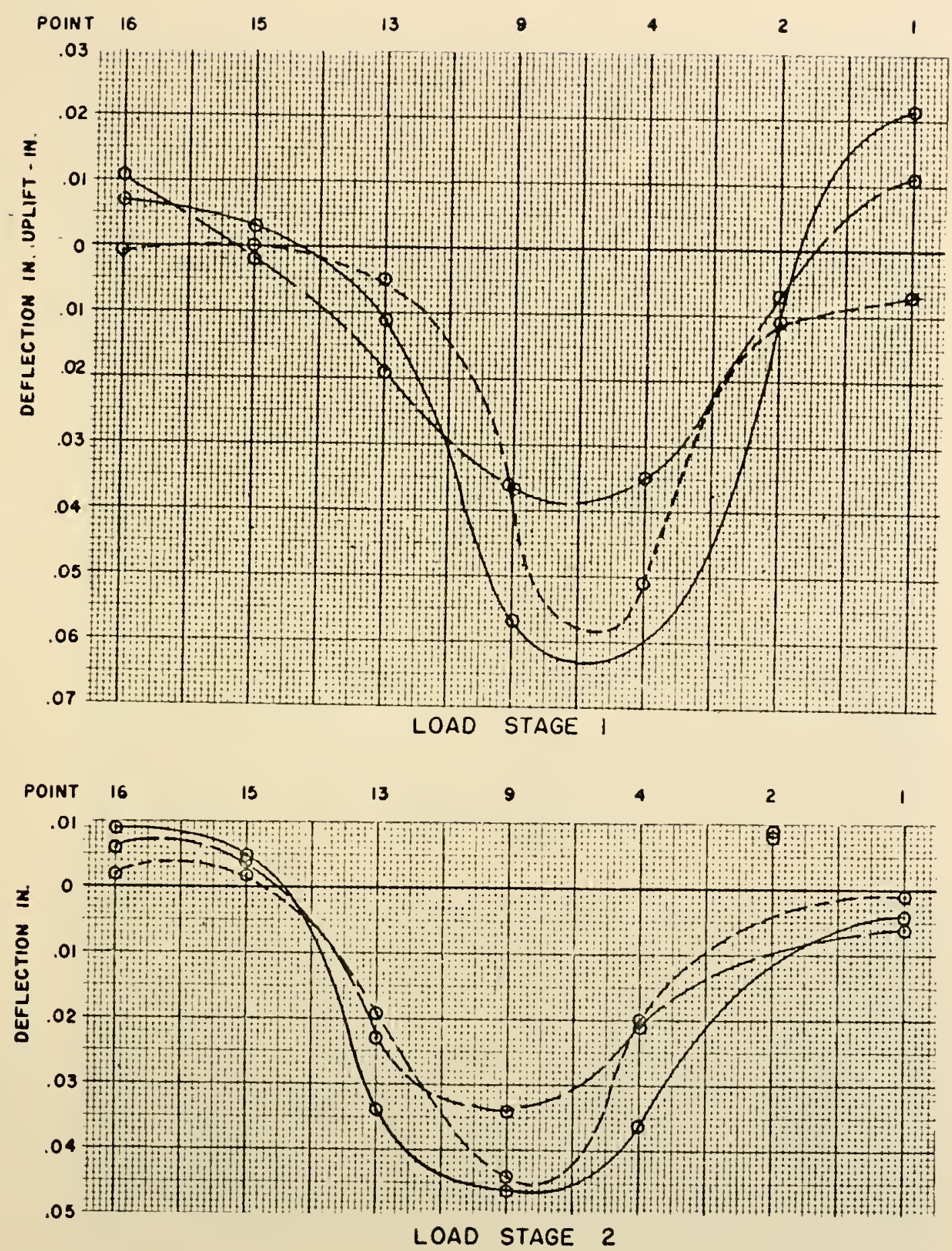

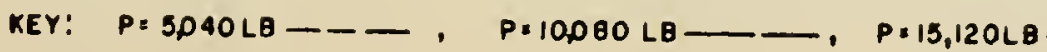

FIGURE 50. LONGITUDINAL CENTER LINE DEFLECTION, 4'-O" BEAM SPACING, LOAD STAGES I AND 2 

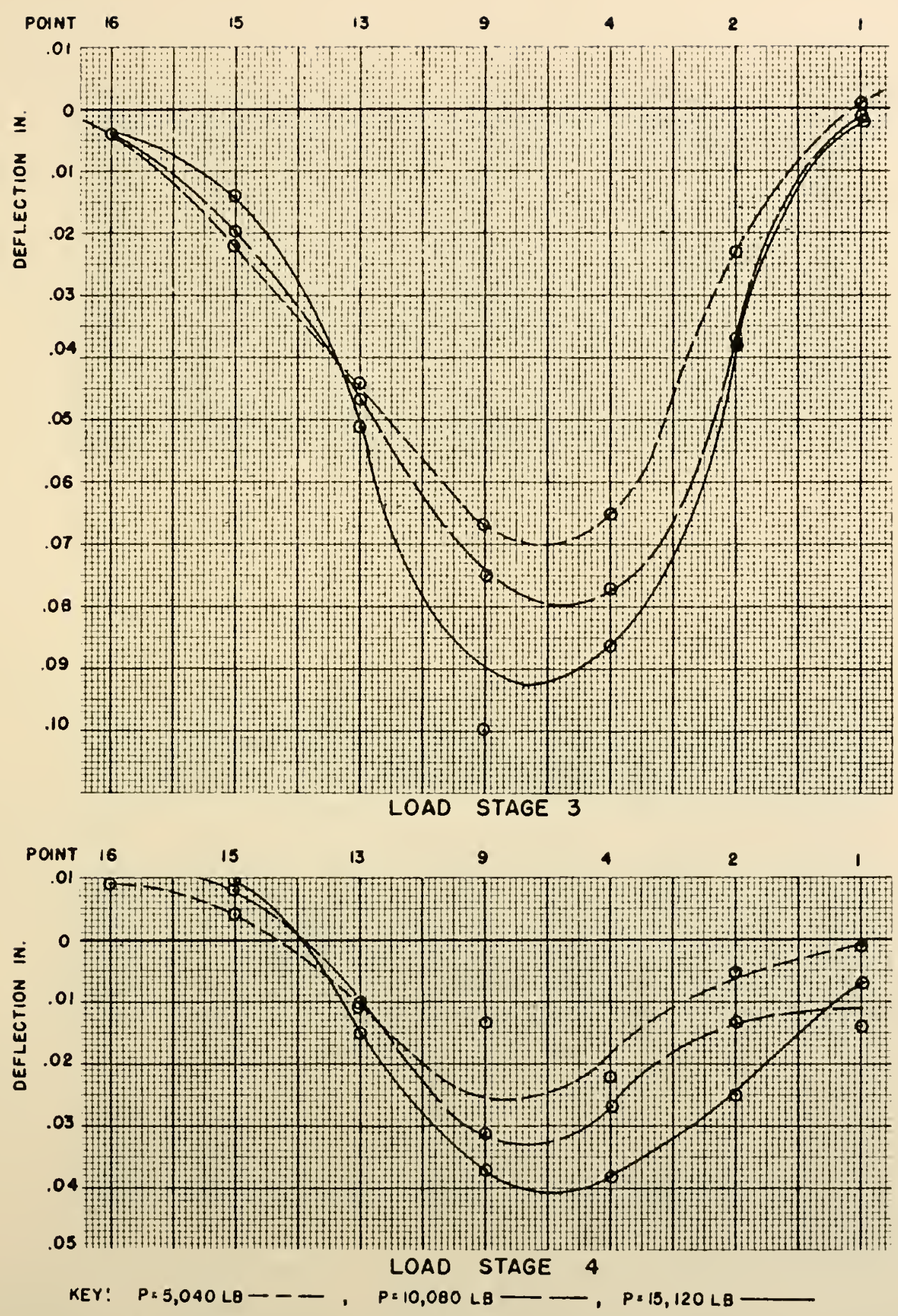

FIGURE 5I. LONGITUDINAL CENTER LINE DEFLECTION, 4'-0" BEAM SPACING, LOAD STAGES 3 AND 4 

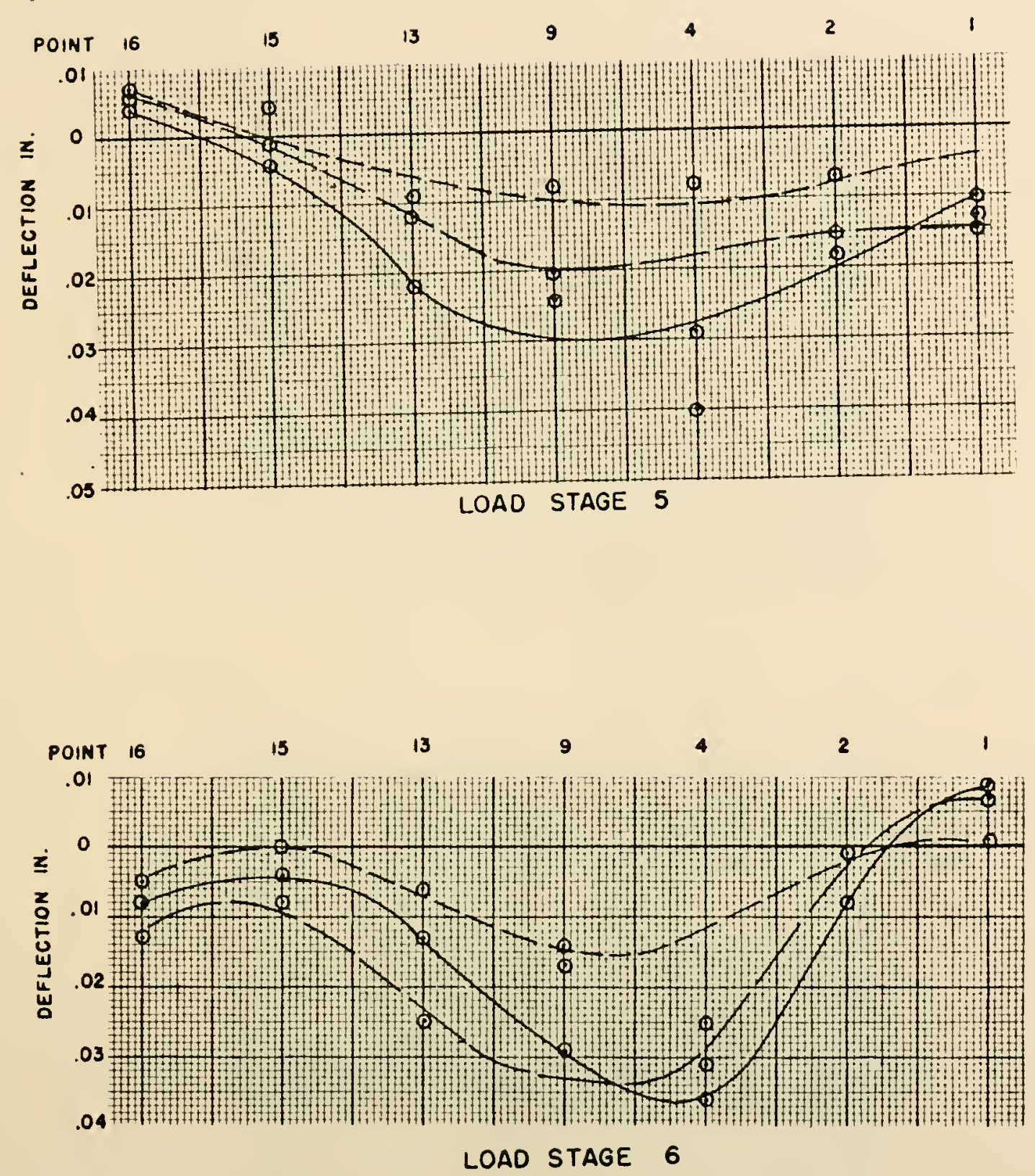

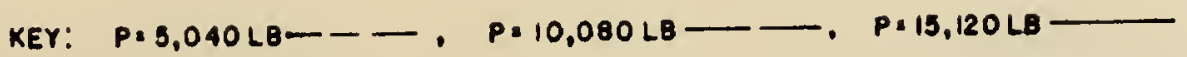

FIGURE 52. LONGITUDINAL CENTER LINE DEFLECTION, 4'-O" BEAM SPACING, LOAD STAGES 5 AND 6 

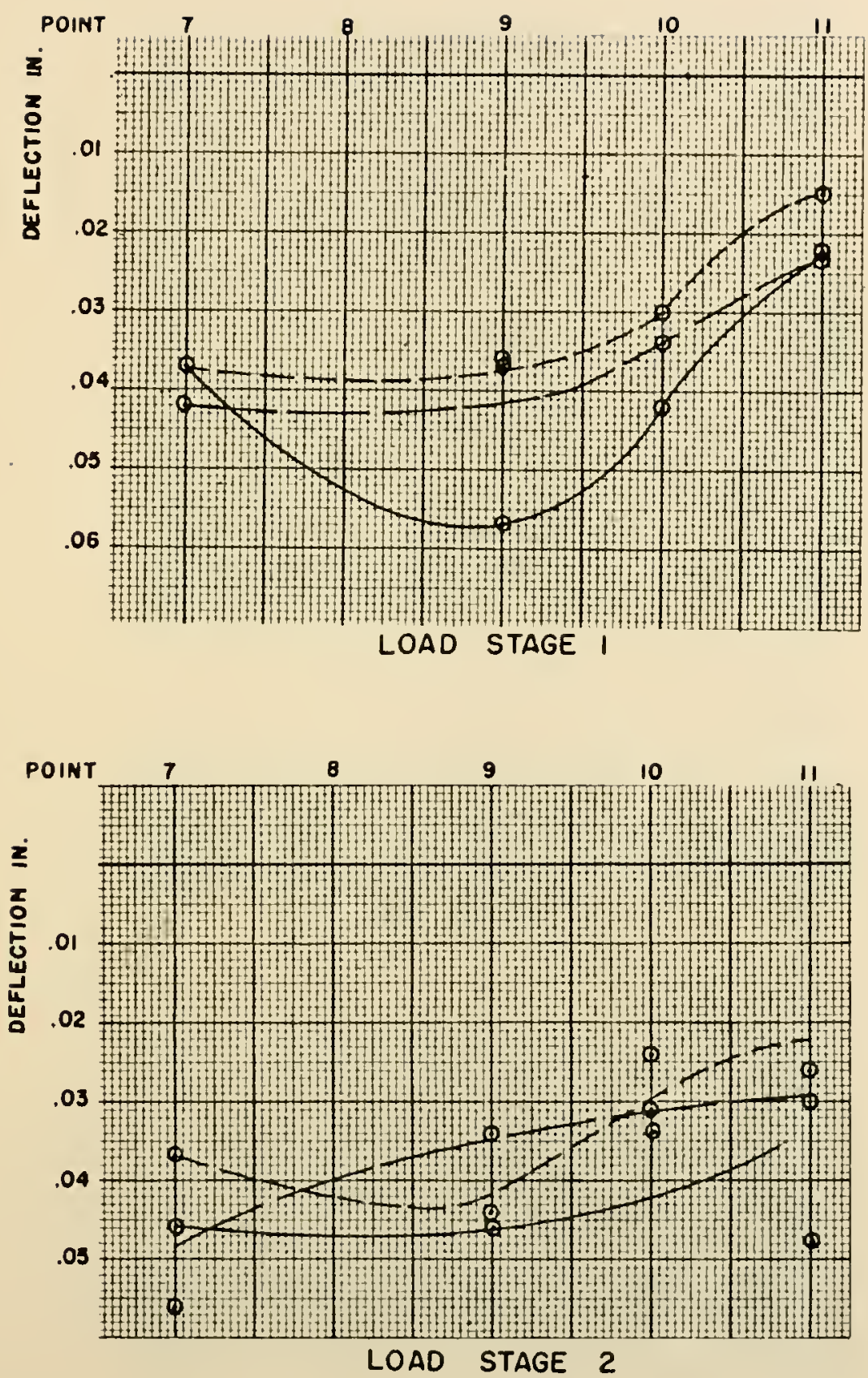

KEY: $P=8,040$ LB - - $P=10,080$ LB

$P=15,120<B$

FIGURE 53. TRANSVERSE LINE DEFLECTION NEAR LOAD, 4'-0" BEAM SPACING, LOAD STAGES I AND 2 

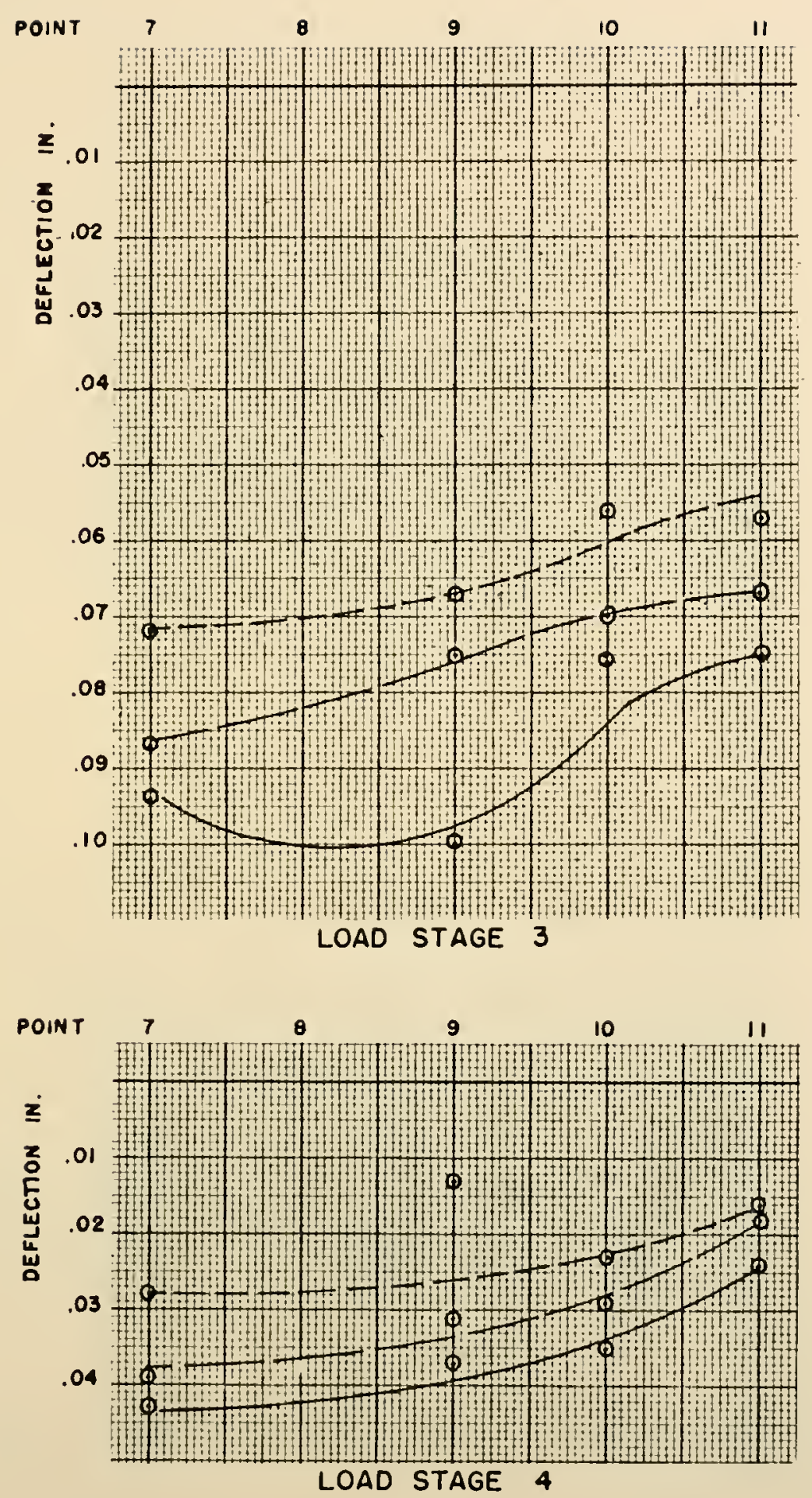

KEY: $P: 5,040 L B+\ldots, P=10,080 L 8$

$P=15,120$ LB

FIGURE 54. TRANSVERSE LINE DEFLECTION NEAR LOAD, 4'-0" BEAM SPACING, LOAD STAGES 3 AND 4 

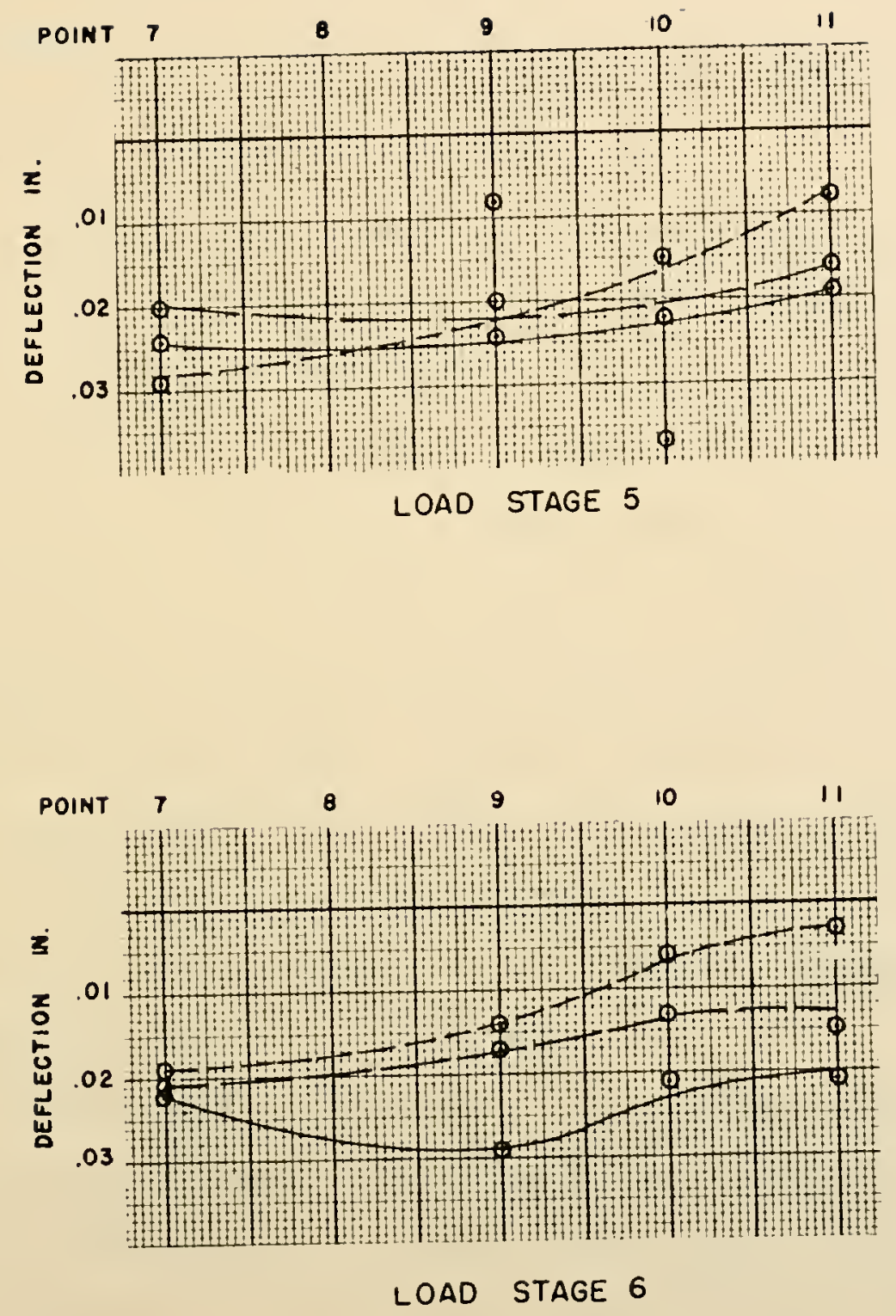

KEYI P: 5,040 LB - $-, P=10,080 \mathrm{LB}$ $P=15,120<B$

FIGURE 55. TRANSVERSE LINE DEFLECTION NEAR LOAD, 4'-O" BEAM SPACING, LOAD STAGES 5 AND 6 
$\Delta R_{1}$, can be represented as $\frac{\Delta L}{L}$ and is related to the gage factor of the strain gage by the exprossion $\frac{\Delta L}{I}=\frac{\Delta R_{I}}{R_{I}} \times \frac{1}{G \cdot F}$. Now, entering the applied voltage and equivalent value of $\frac{\Delta R_{1}}{R_{1}}$, the expression for the circuit output becomes $E=\frac{\Delta L}{L}$ (G.F.) or, letting $\varepsilon$ denote the strain, $\frac{\Delta L}{L}, e=\frac{E}{G . F}$. for the circuit used.

Sources of Error arise in not takdng into account the length of lead-wires and in voltage supply drift. Flrst, considering the effect of the lead-wires, the resistivity of the wire used was 0.043 obms per foot measured at $75^{\circ} \mathrm{F}$. Assuming a maximum $20 \mathrm{ft}$. lead, there would be an effective resistance of $1.72 \mathrm{ohms}(.043 \times 40)$ due to the length of the lead wires. This would translate to $E=\frac{V}{4.06} \frac{\Delta R_{1}}{R_{1}}$ or a discrepancy of 1.5 percent from the assumed val ue of 4.00 in the denominator of the expression. The second possible source of error would be in roltage supply drift. Maximu drlft observed during the test was .005 volts, a 0.125 percent discrepancy from the 4 volts assumed. Neither of the above discrepancles was consldered signiflcant enough to necessitate rejection of the method.

Por each load stage (see Table 9), a voltage reading was made for ach chamel prior to load and subsequent readings were taken after changes in appiled load. In this way, the voltage change which translates to strain as indicated above, was an indication of the performance of the deck dus to flearure.

Strain Gage Application was made using Duco (T.M.) Cement. The concrete surface had first been sanded, cleaned with acetone, and covered with a layer of Duco Cement which was permitted to dry. The 
paper gage backing was trimed to within approxdmately $1 / 16$ inch of the protective felt pad, the desired location of the gage grid center was marked on the conerete surface, and a new lajer of Duco Cement was placed at the desired gage location. The gage was pressed onto the prepared concrete surface and all excess cenent and air bubbles were worked to the edges of the gage backing. Gage grid centers were 10ceted $3 / 4$ inch in both longltudinal and transverse diroctions from the points indicated in Figures 56 and 57. Lead wires were then soldered to the strain gage leads and were run to the switch and balance units.

\section{Results}

The results of the testing for beam spacings of 4'-0" are presented as Figures 50 thru 55 and Figures 58 thru 63. Table 9 gives the conditions of applied load, bolting, and post-tensfoning during the load stages referred to in the figures.

The load stages which most closely approsdmate conditions anticlpated in a fleld application are numbered four and five.

Maximum deflections during load stages 4 and 5 were observed to occur when the post-tensioning was at its highest level. This is illustrated in Figures 51 and 52 , load stages 4 and 5. The post-tensioning in load stage 518 approxdmately $2 / 3$ of the level of posttensionting in load stage 4; this corresponds to a deflection in load stage 5 of approxdmately $3 / 4$ of the deflection in load stage 4.

In all cases, deflection was decreased due to bolting. The maxImum observed deflections of load stage 3 were decreased by more than half by bolting in load stage 4 (whlle maintaining the same posttensioning stress in load stage 4) as shown in Flgure 51. This holds 


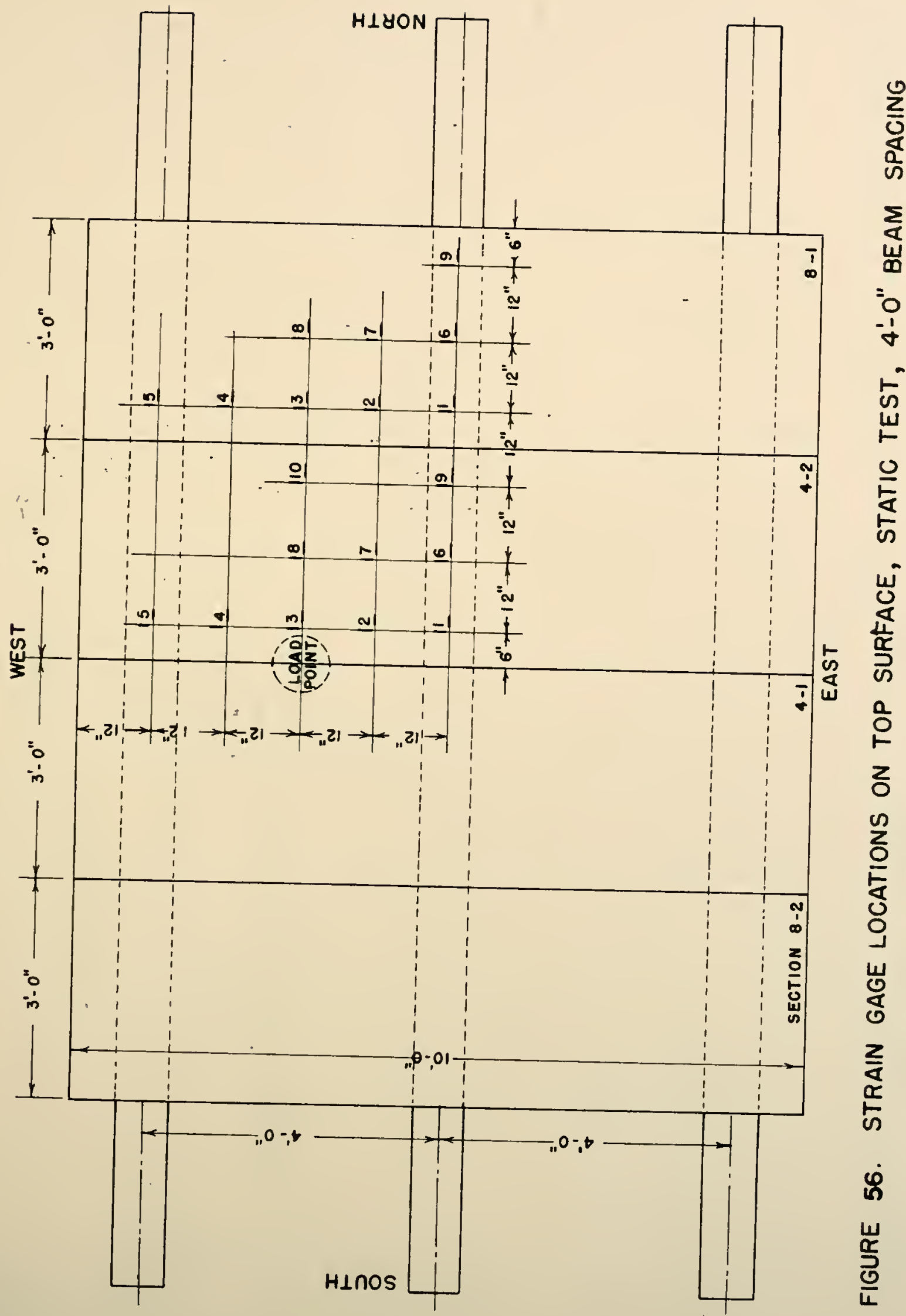




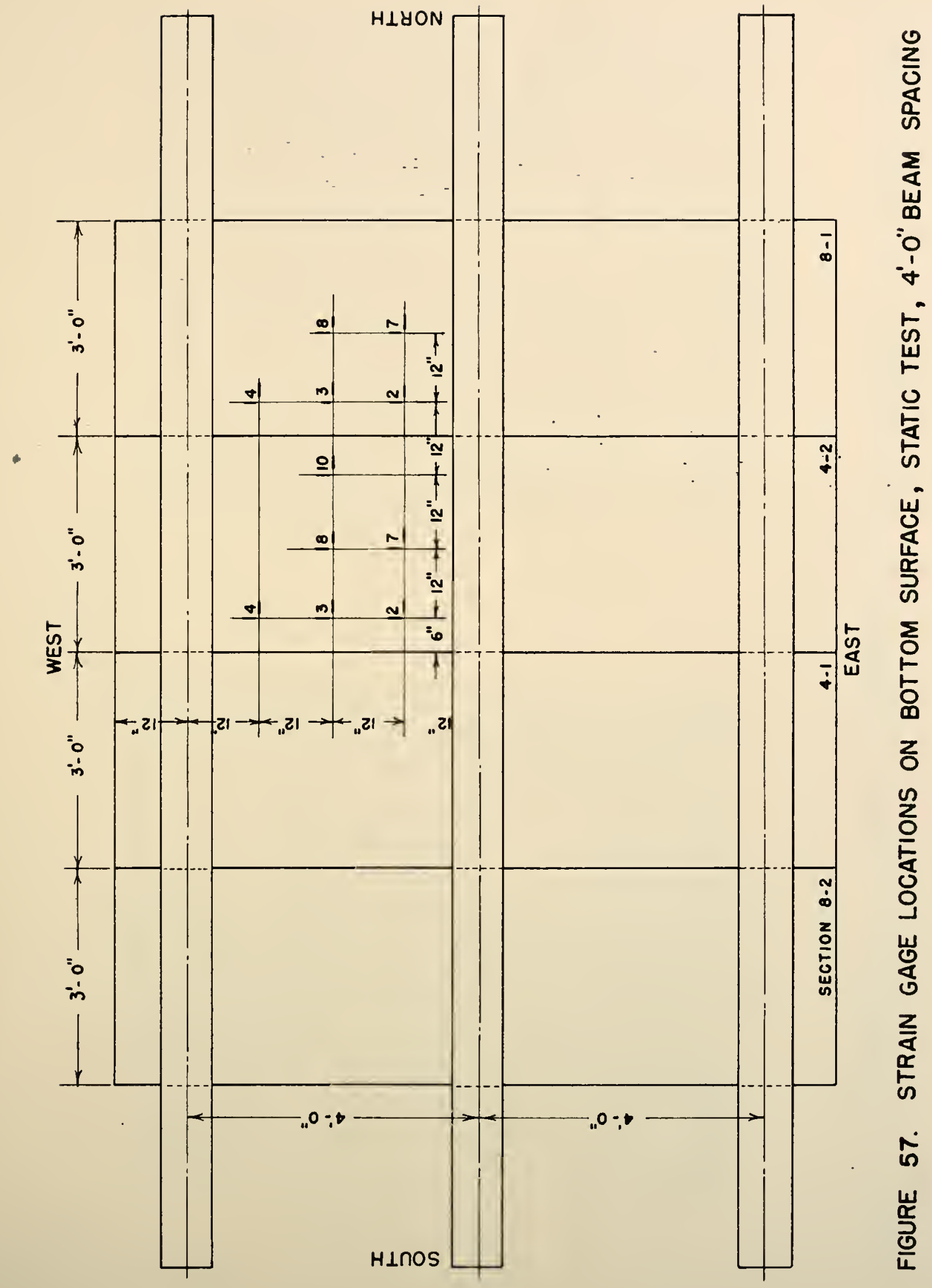



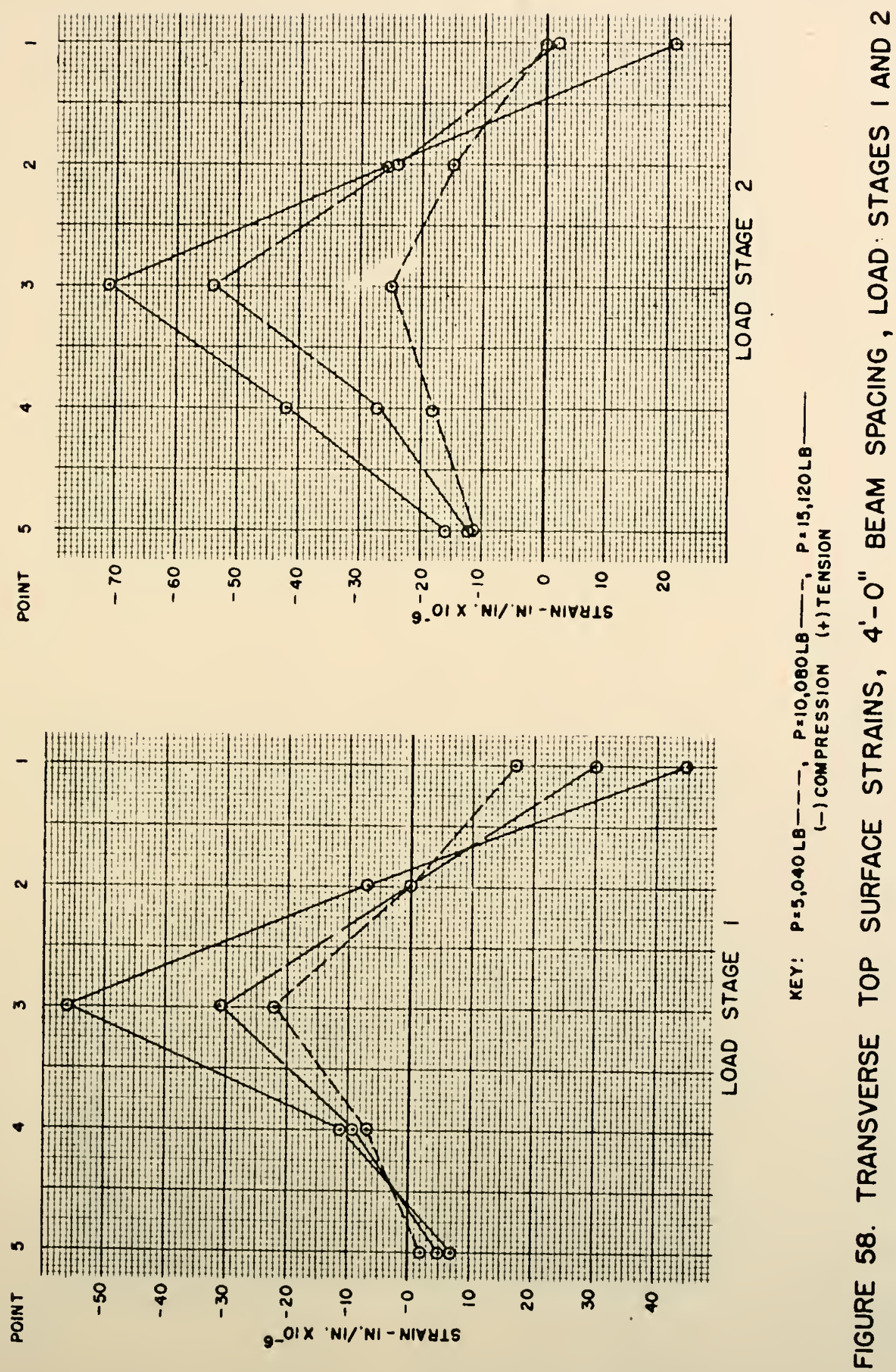

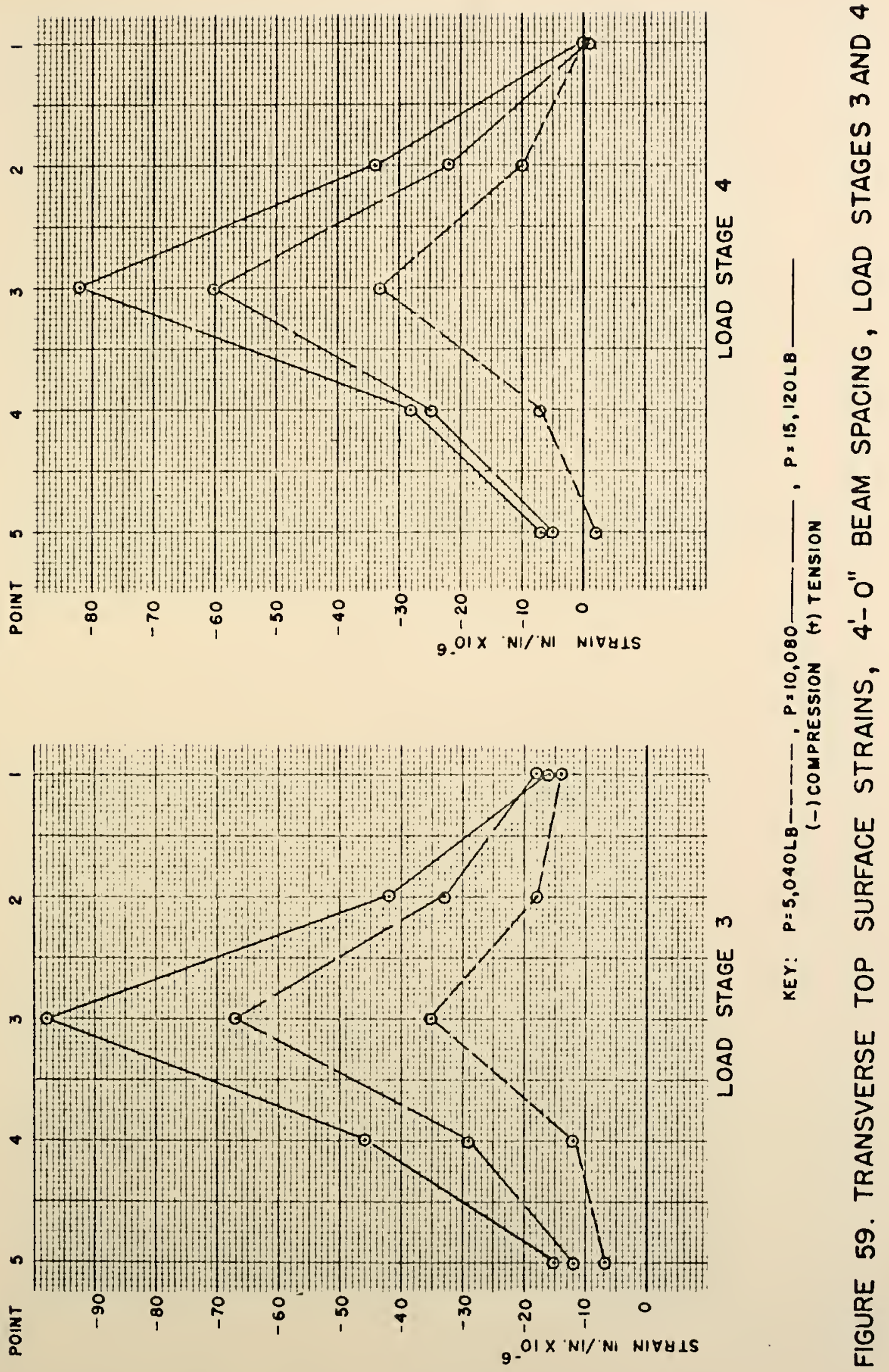

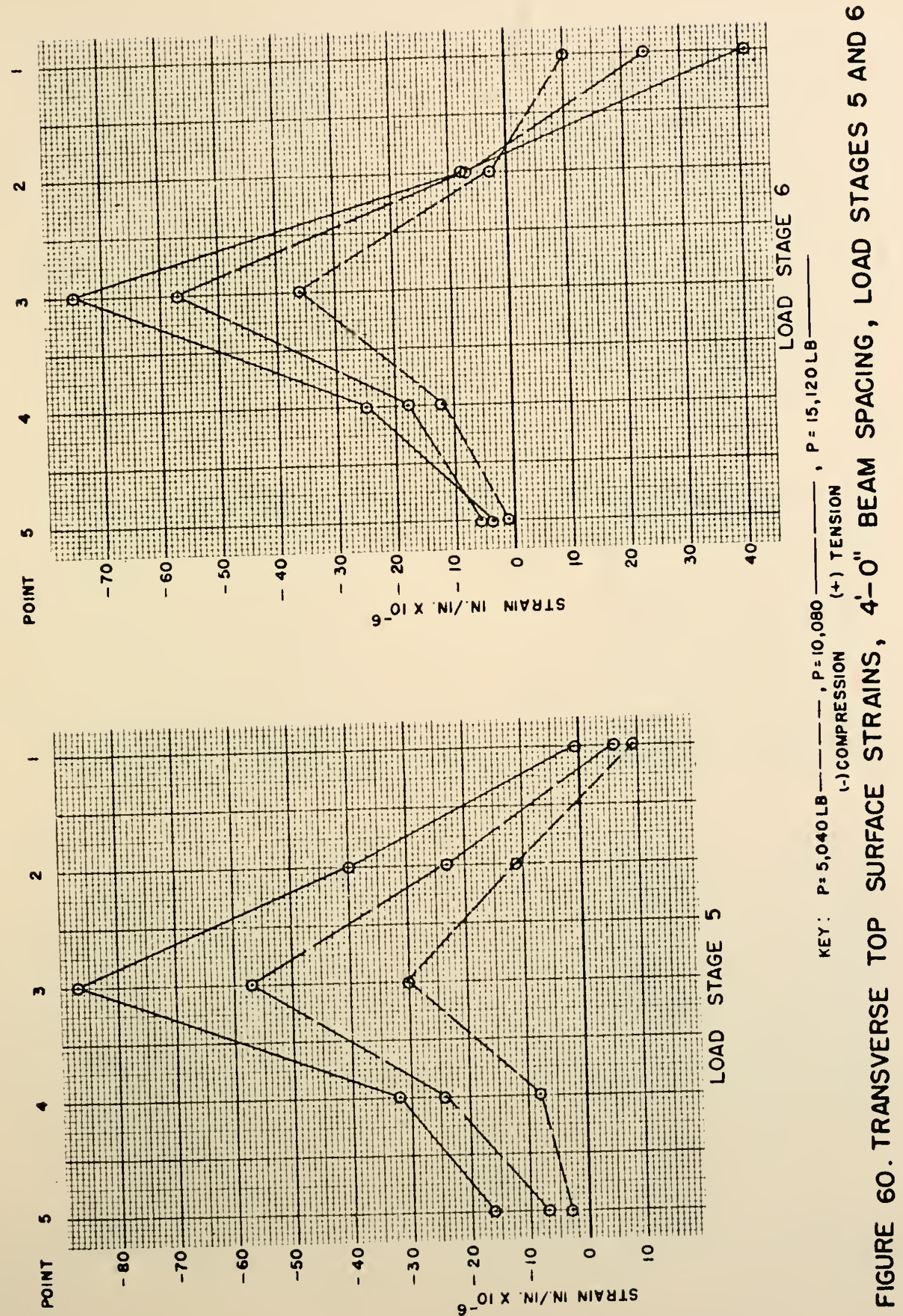

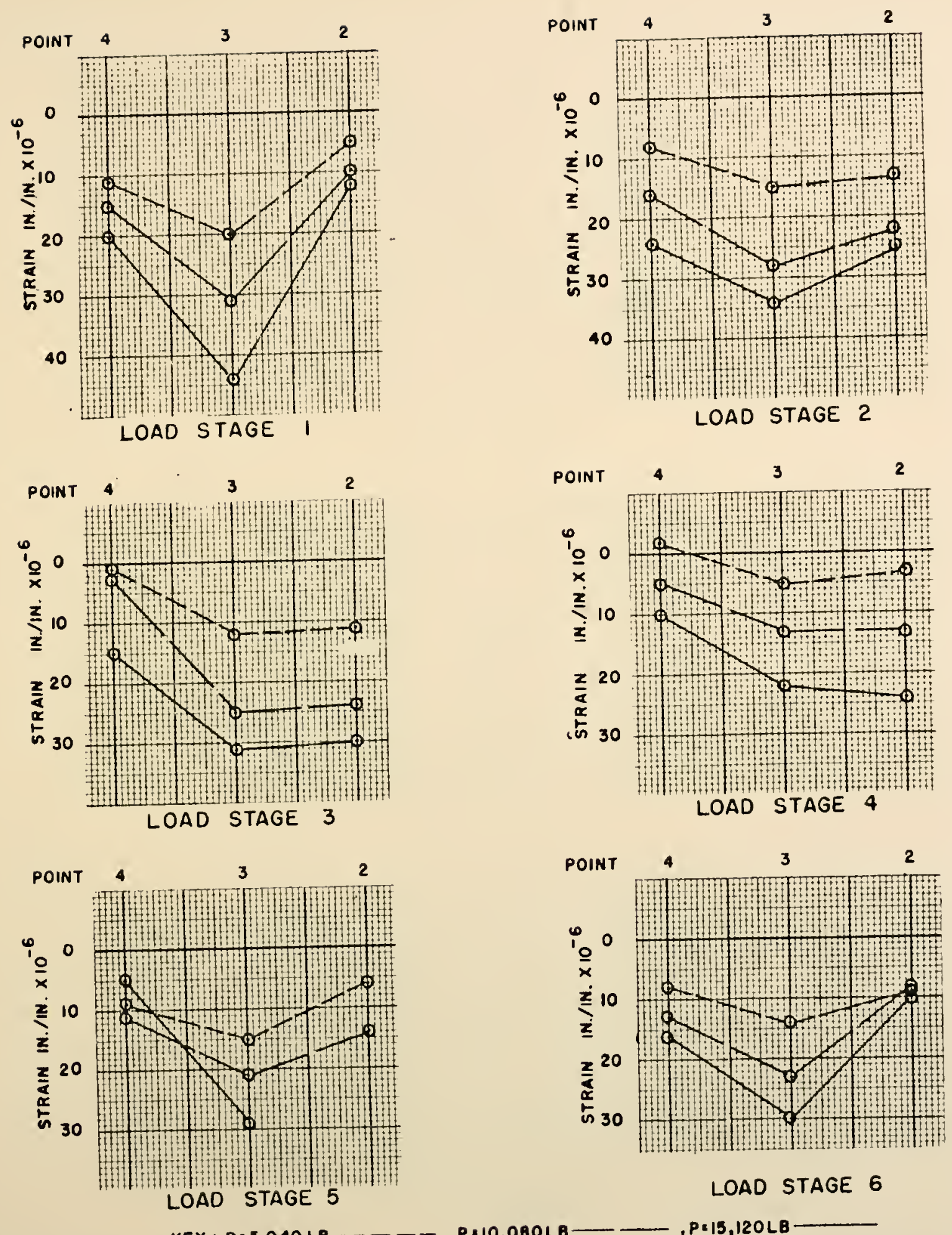

$$
\begin{aligned}
& \text { LOAD STAGE } 5 \\
& \text { KEY P P } 5,040 \text { L8- LOAD STAGE } 6 \\
& \text { (t) TENSION }
\end{aligned}
$$

FIGURE 61. TRANSVERSE BOTTOM SURFACE STRAINS, 4'-0" 

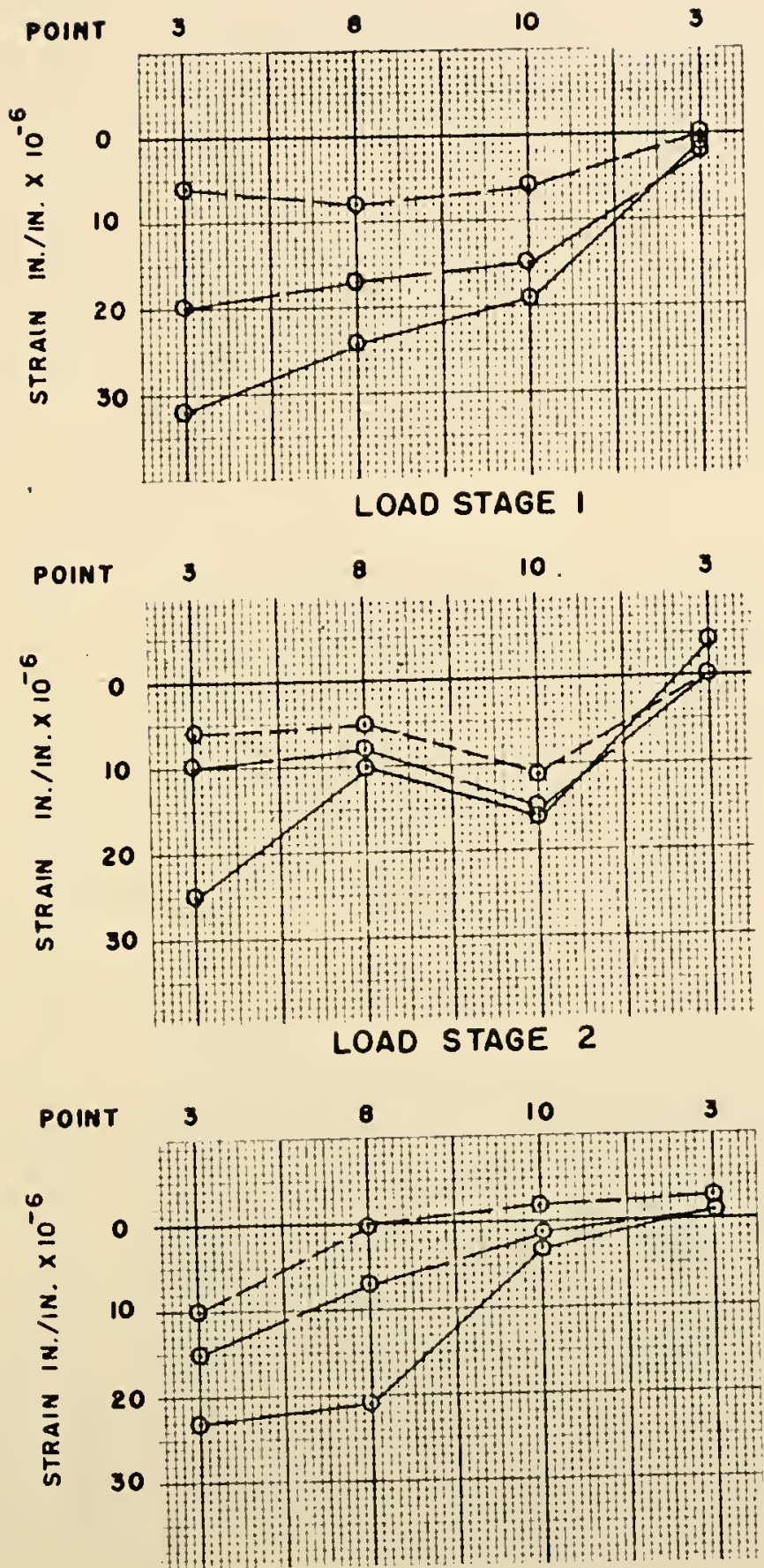

\section{LOAD STAGE 3}

KEY: $P=5,040 \mathrm{LB}-\ldots, P=10,080 \mathrm{LB}-, P=15,120 \mathrm{LB}$

(t) TENSION

FIGURE 62 . LONGITUDINAL STRAIN MEASURED ON LONGITUDINAL CENTER LINE, 4-O"BEAM SPACING, LOAD STAGES 1,2 , AND 3 , TOP SURFACE 

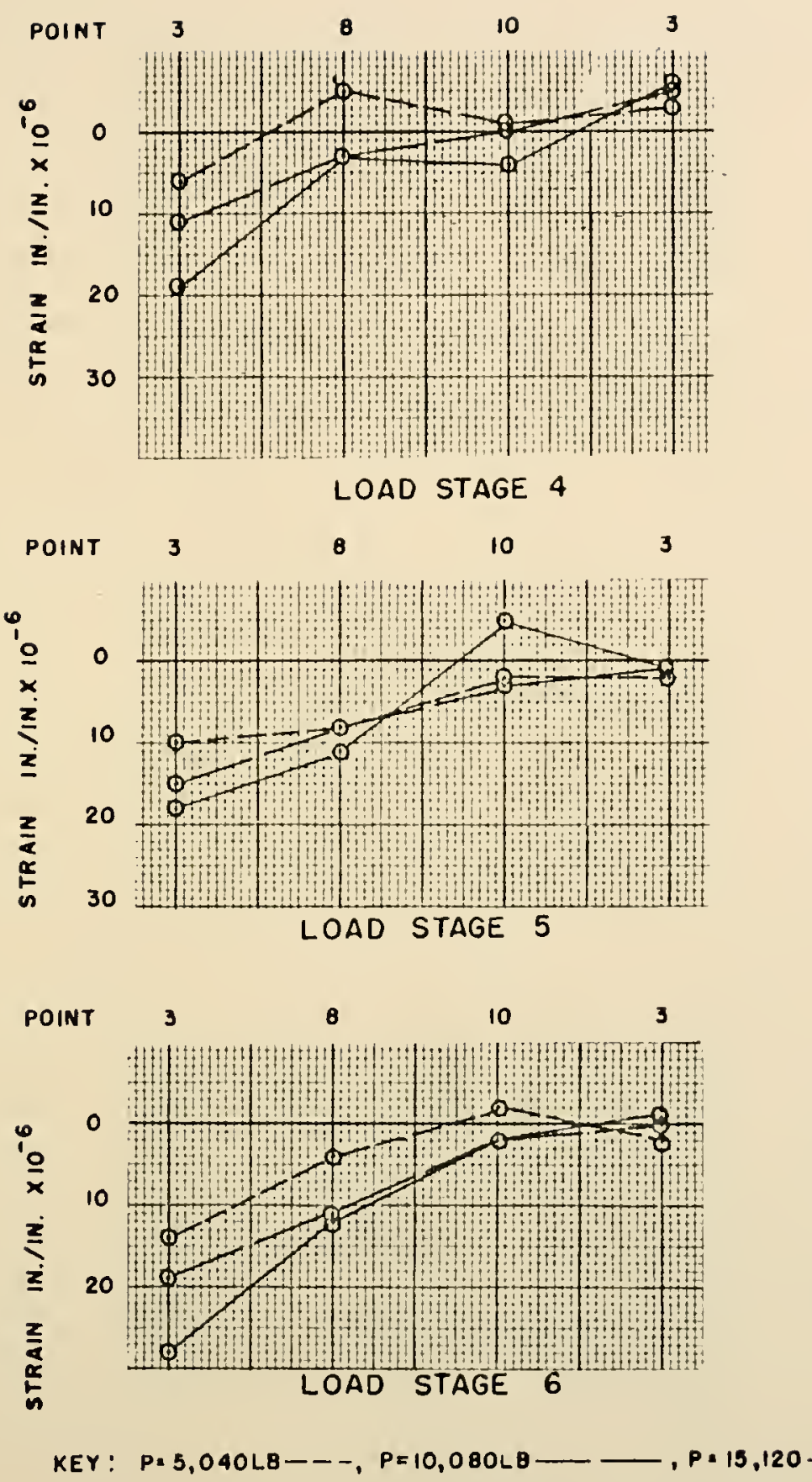

$(+)$ TENSION

FIGURE 63. LONGITUDINAL STRAIN MEASURED ON LONGITUDINAL CENTER LINE, 4'-O"BEAM SPACING, LOAD STAGES 4,5 , AND 6 , TOP SURFACE 
true for transverse as well as longitudinal line deflectlons. The decrease is most likely attributed to an increased continuity action caused by pulling the slabs and beams together by bolting.

Strain readings indicated a very small particlpation in load carryling by deck sections mor than one sectlon away from the load polnt. Near the load point, top and bottor stratns varied signiflcantly In that the bottom surface strains were of smalzer magnitude. Examination of the top and bottom transverse strains at points 3, 8, and 10 would indicate that the discrepancy is greatest near the loaded joint and that otrains somewhat more distant from the joint vary nearly Iinearly through the alab as would be predicted. One would not necessarily predict agreement between top and bottom strains due to the possiblity of eccentricity of the prestressing strand. Owing to the outward appearance of the slabs reinforced for 4'-O" beam spacing upon their delivery, (see Figure 33) it is evident that a loss in bond betwoen the prostrossing strand and the concrete might have caused the non-linear strain distribution. The top surface showed signs of distross along the prestressing strand with a definite crack pattern in evldence. The bottom strands were more likely well bonded as no crackIng was oberved. Inls is in Iine with the high top surface strains and the low bottom surface strains which were measured.

Strains shown may be translated to stresses by multiplying the Indicated strain by the modulus of elasticity of $3.86 \times 10^{6}$ pel.

Returning to the AASHO equation for bending moment due to live Ioad, LIM $=0.8 \frac{(s+2)}{32} \mathrm{P}$ where $P$ is the whool load. If one takes the value of $P$ as the applied load during the test of 15,120 1b, the 
IIM becomes 6,390 It-Ib on a 3'-O" section; calculated bending strosses become $\pm 350 \mathrm{psi}$. The bending stresses for this load observed in load stages 4 and 5 respectively were $316 \mathrm{psl}$ and 336 psi, measured on the top ourface. This would indicate a good prodictability of stresses due to live load using the present AASHO equation. The uniform axial prestress of $545 \mathrm{psi}$ (compression) is adequate to maintain the section in compression due to applied load.

Static Testing of Specimens Reinforced for $8^{\prime}-0^{\prime \prime}$ Beam Spacing

Description of Test

The static testing for a beam spacing of $8^{\prime}-0$ " was conducted in the same manner as the previous test for the 4'-0" bean spacing. The testing arrangement is shown in Figures 64 and 65 . Loads and strains were determined as in the provious test, and deflection measurements were similarly made.

The deflection data are indicated in Figures 66 thru 68. Doflections which were moasured may be found in Appendix B, Table 16. An error in the zero reading of the points above the supports on the transverse line was apparently made, as the data would indicate more deflection at the point of support than at points closer to the load and for that reason no figures appear to 1 llustrate transverse Iine deflections. The load stages for the test are shown in Table 15, with bolting locations shown in Figure 66.

\section{Results}

The largest deflections observed occurred under the highest post-tensioning level; this was also true in the case of the $4^{2}-0^{n}$ beam 


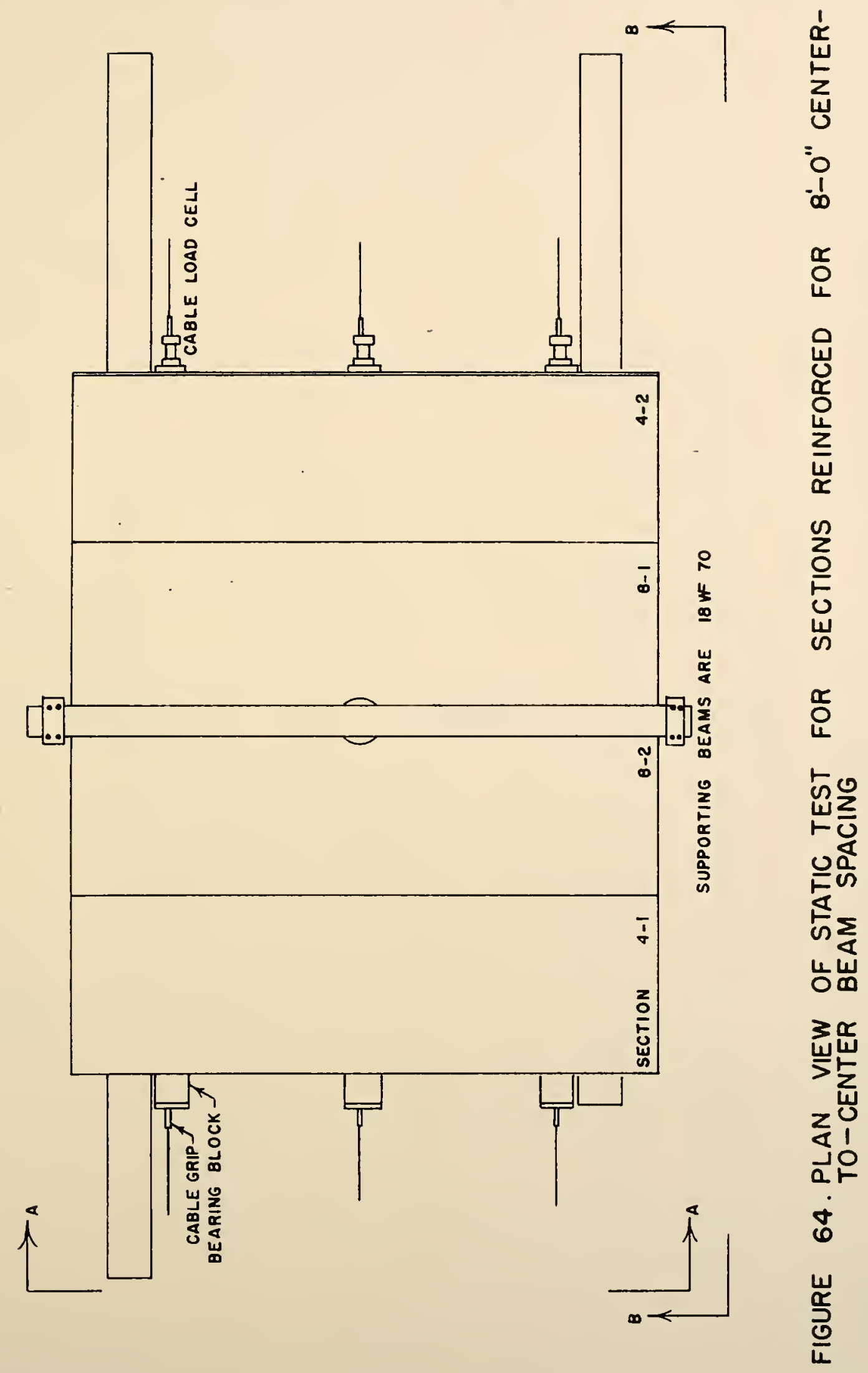



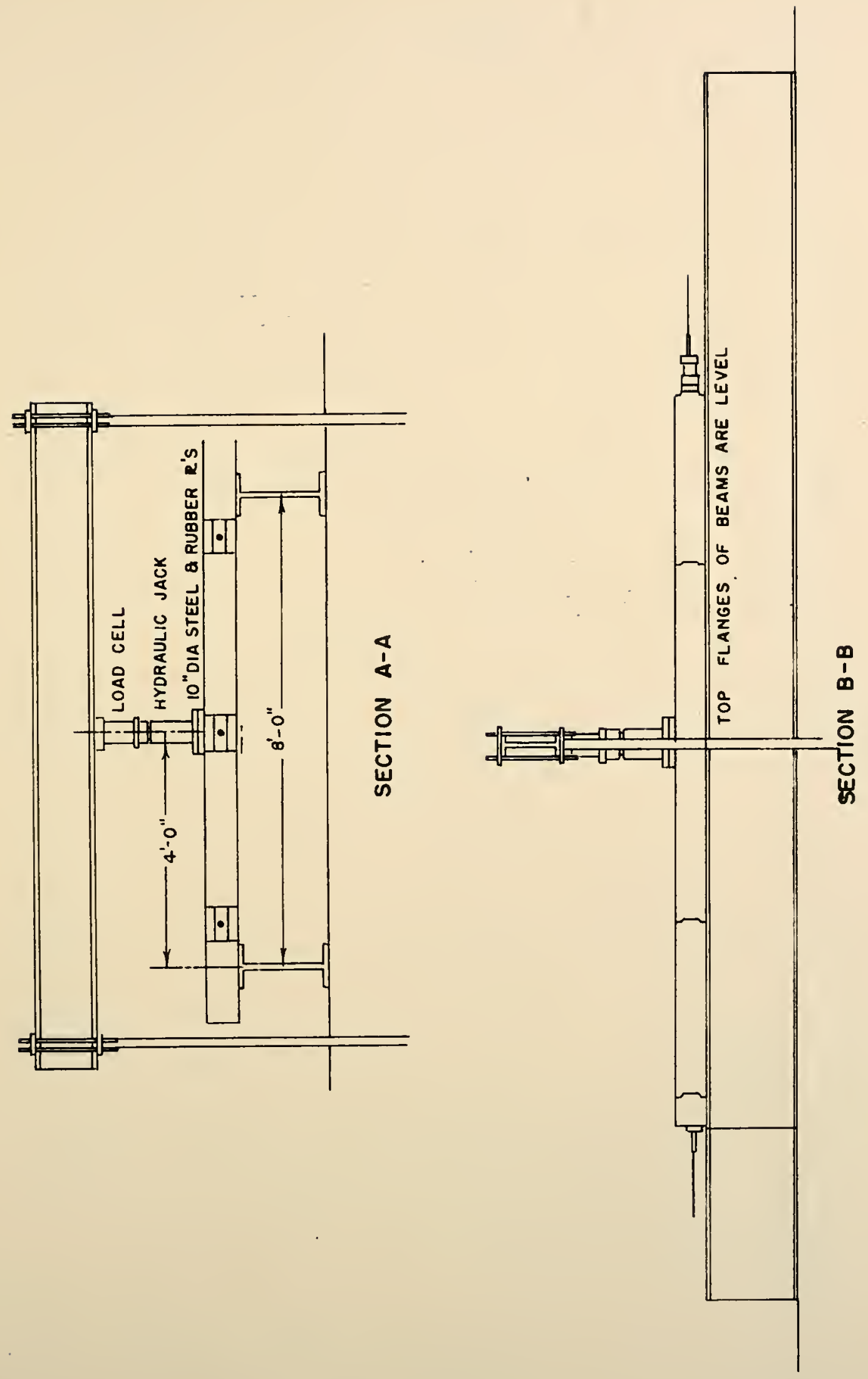

$\frac{0}{3}$

$\frac{\sum}{\omega}$

$=0$
-1

$\frac{I}{5}$

占

唯

$\frac{1}{2}$

号

กீ

容 


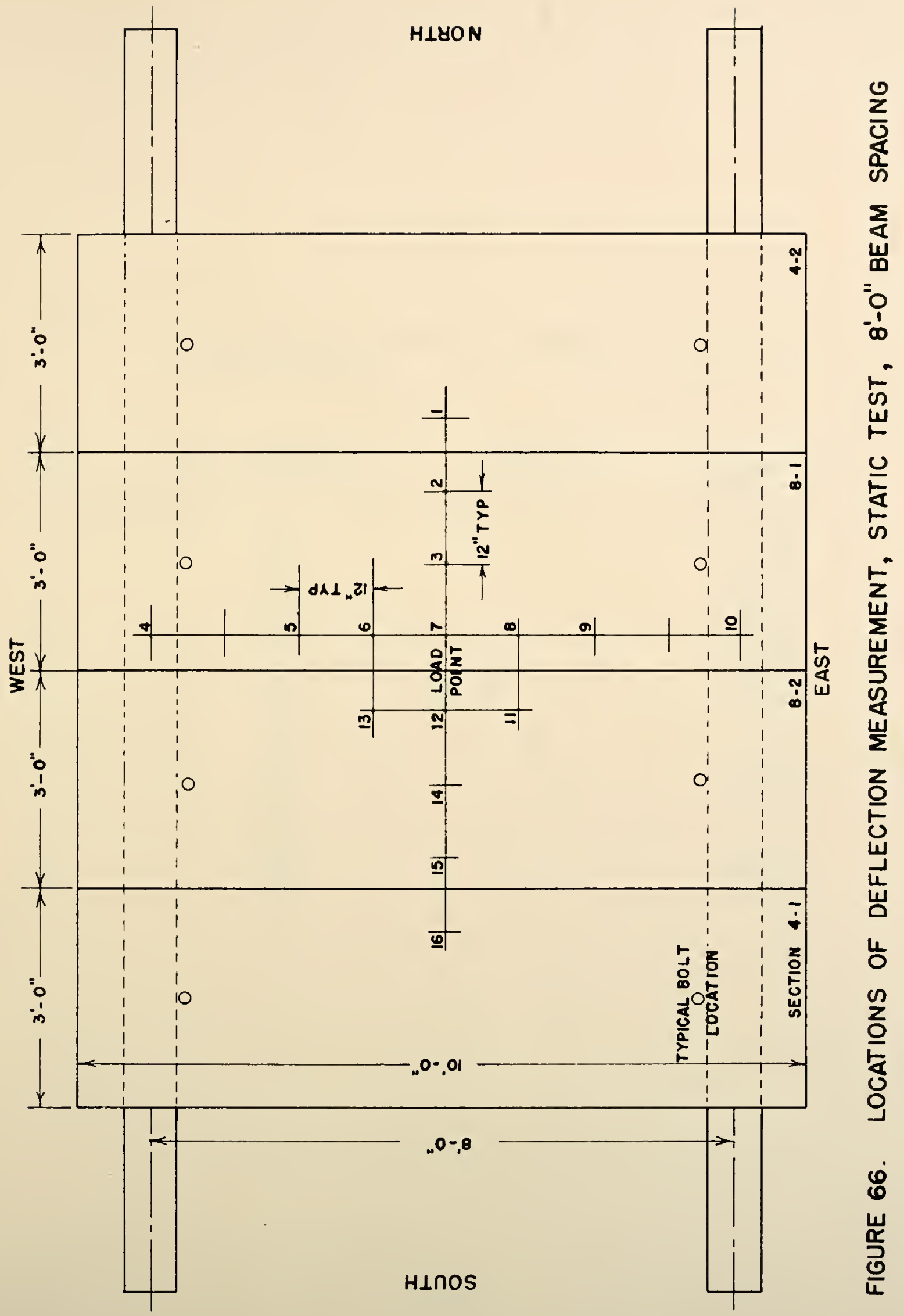


374

Table 10. Load Stages During Testing of Sections Reinforced for 8'-0" Beam Spacing

\begin{tabular}{lccc}
\hline $\begin{array}{l}\text { Load } \\
\text { Stage }\end{array}$ & $\begin{array}{c}\text { Post- Pensioning } \\
\text { (psi on gross section) }\end{array}$ & $\begin{array}{c}\text { Bolting Force } \\
\text { (kips) }\end{array}$ & $\begin{array}{c}\text { Applied Load } \\
\text { (pounds) }\end{array}$ \\
\hline 1 & 19.0 & 0 & 5,040 \\
1 & 19.0 & 0 & 10,080 \\
1 & 19.0 & 0 & 15,120 \\
2 & 36.9 & 0 & 5,040 \\
2 & 36.9 & 0 & 10,080 \\
2 & 36.9 & 0 & 15,120 \\
3 & 36.8 & 32 & 5,040 \\
3 & 36.8 & 32 & 10,080 \\
3 & 36.8 & 32 & 15,120 \\
4 & 20.1 & 32 & 5,040 \\
4 & 20.1 & 32 & 10,080 \\
4 & 20.1 & 32 & 15,120
\end{tabular}



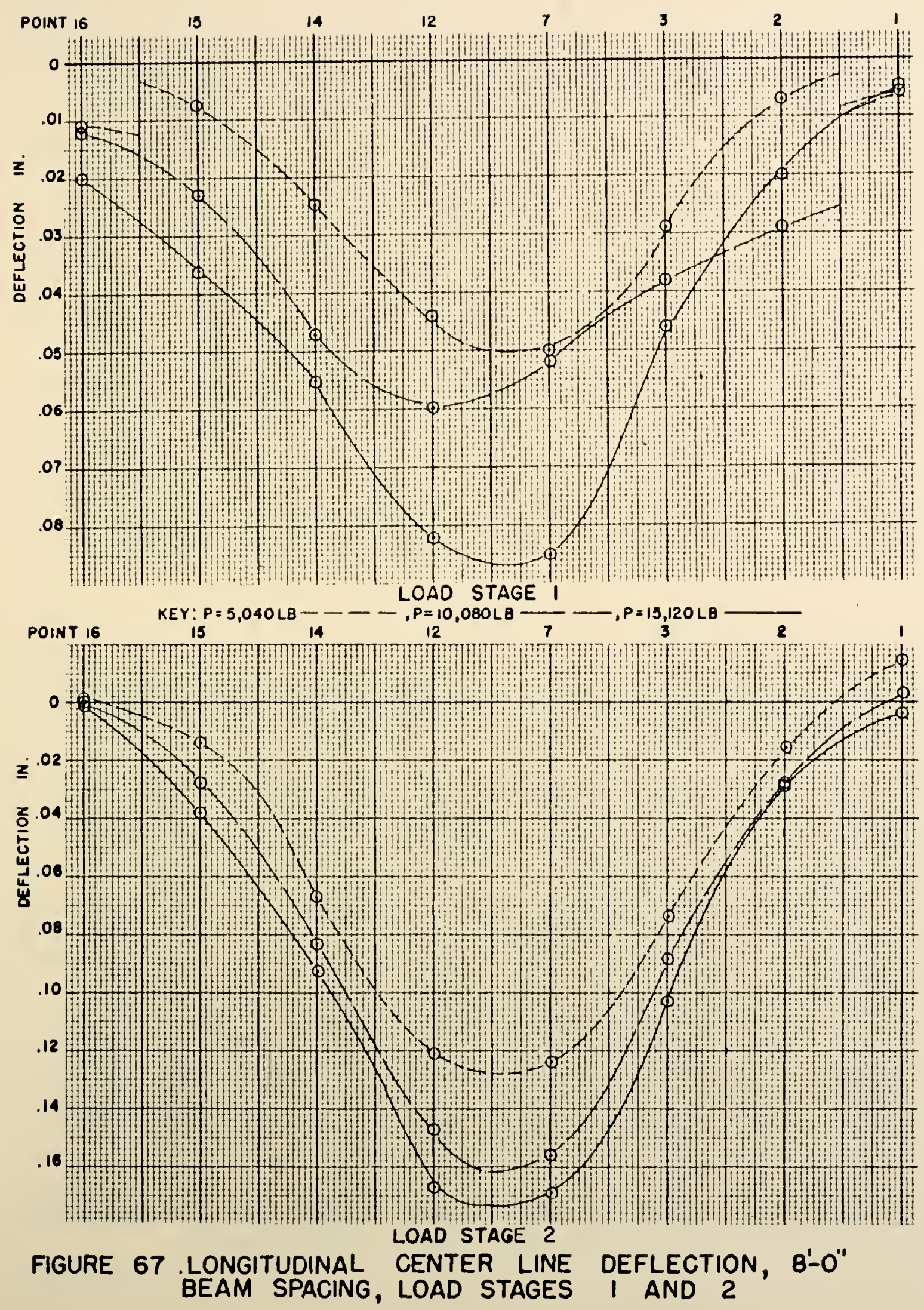

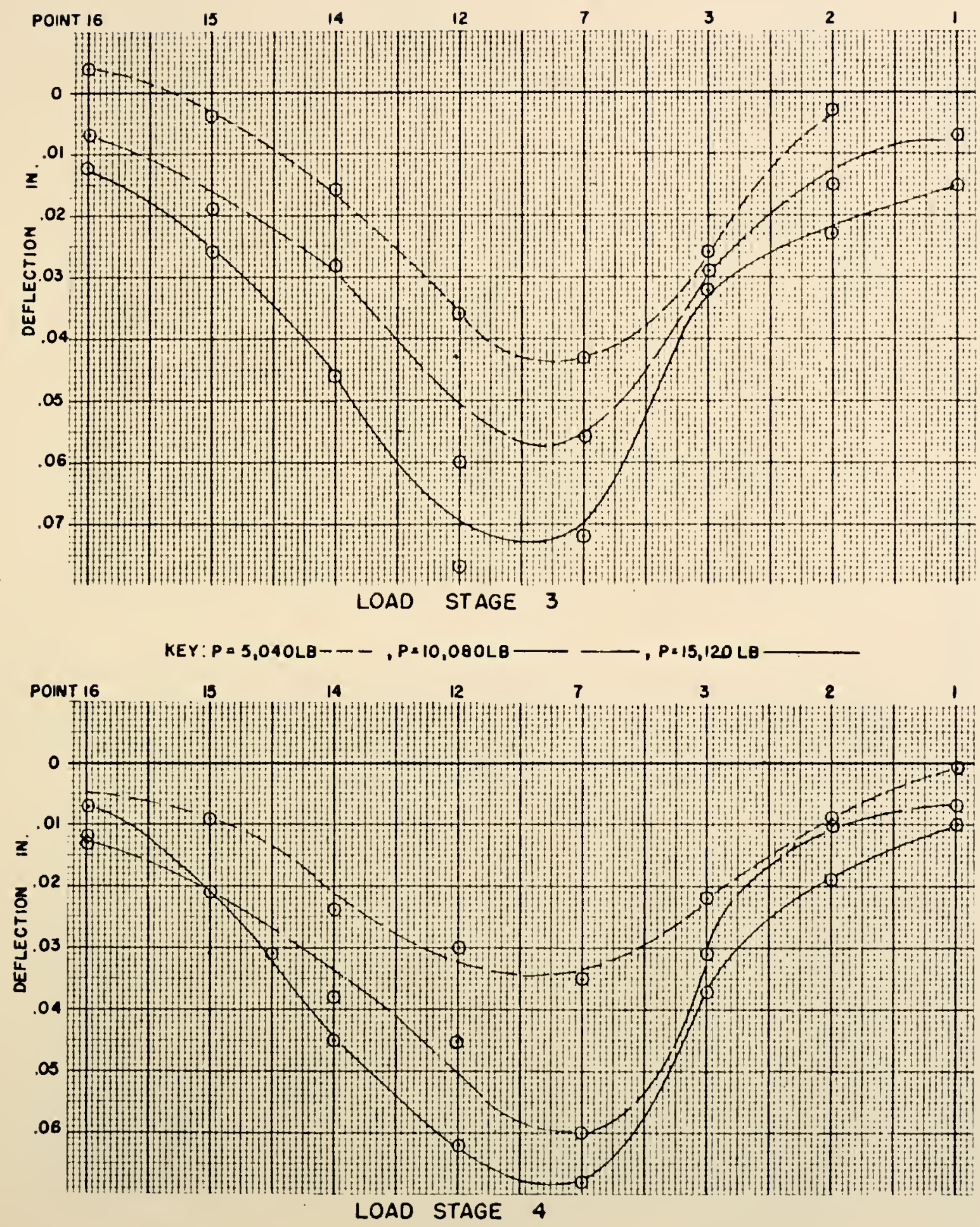

FIGURE 68. LONGITUDINAL CENTER LINE DEFLECTION, 8'-O" BEAM SPACING, LOAD STAGES 3 AND 4 


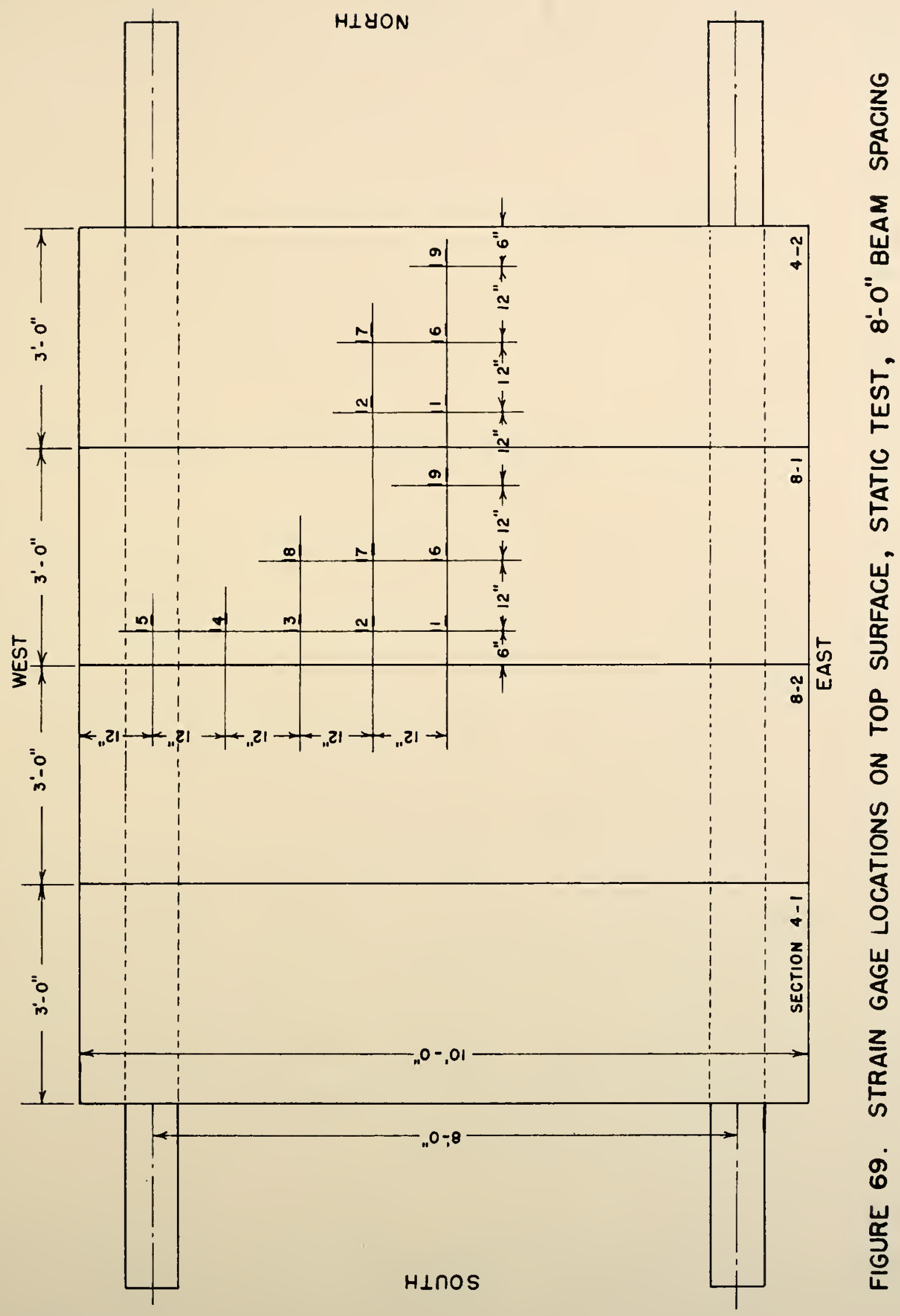




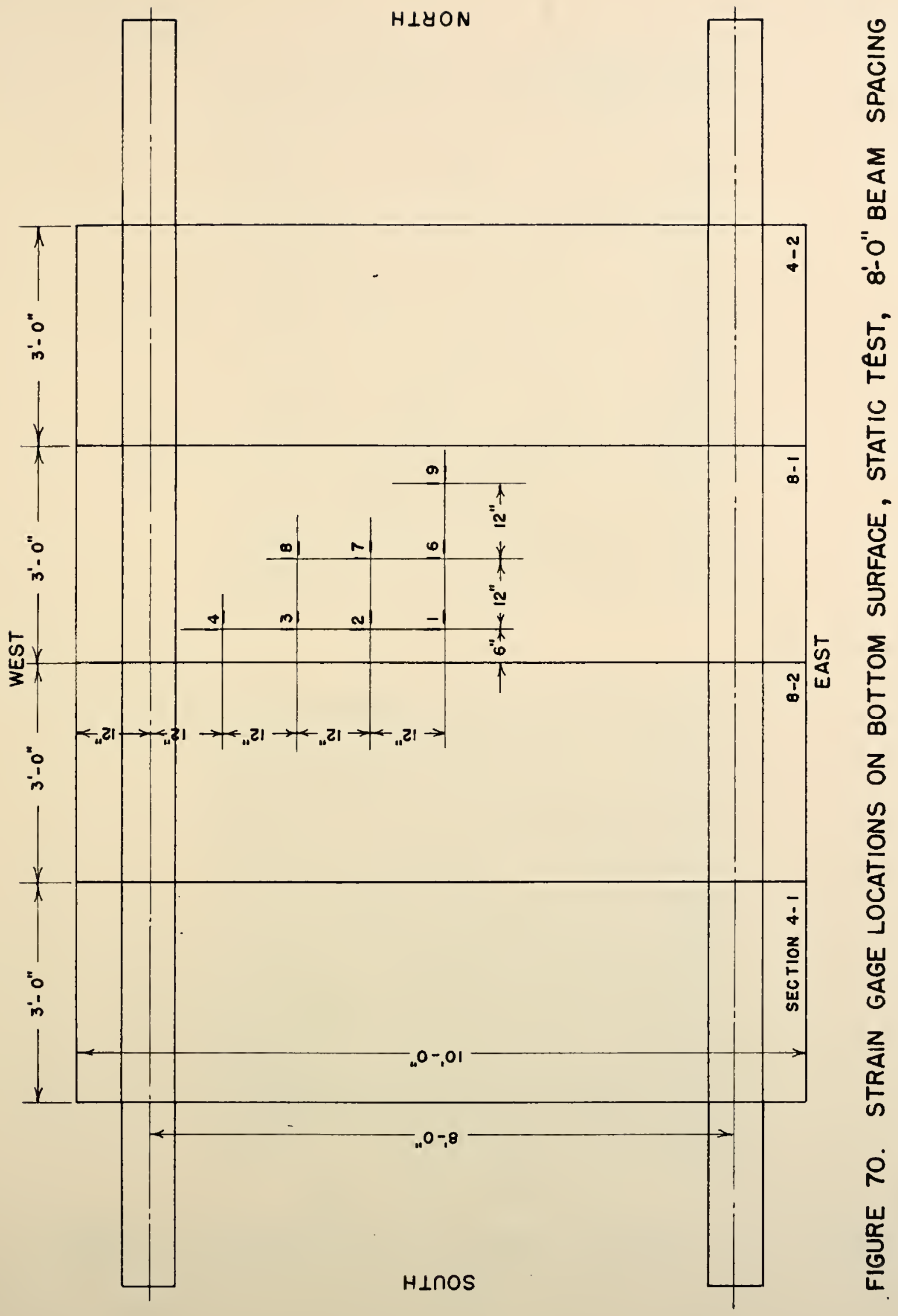



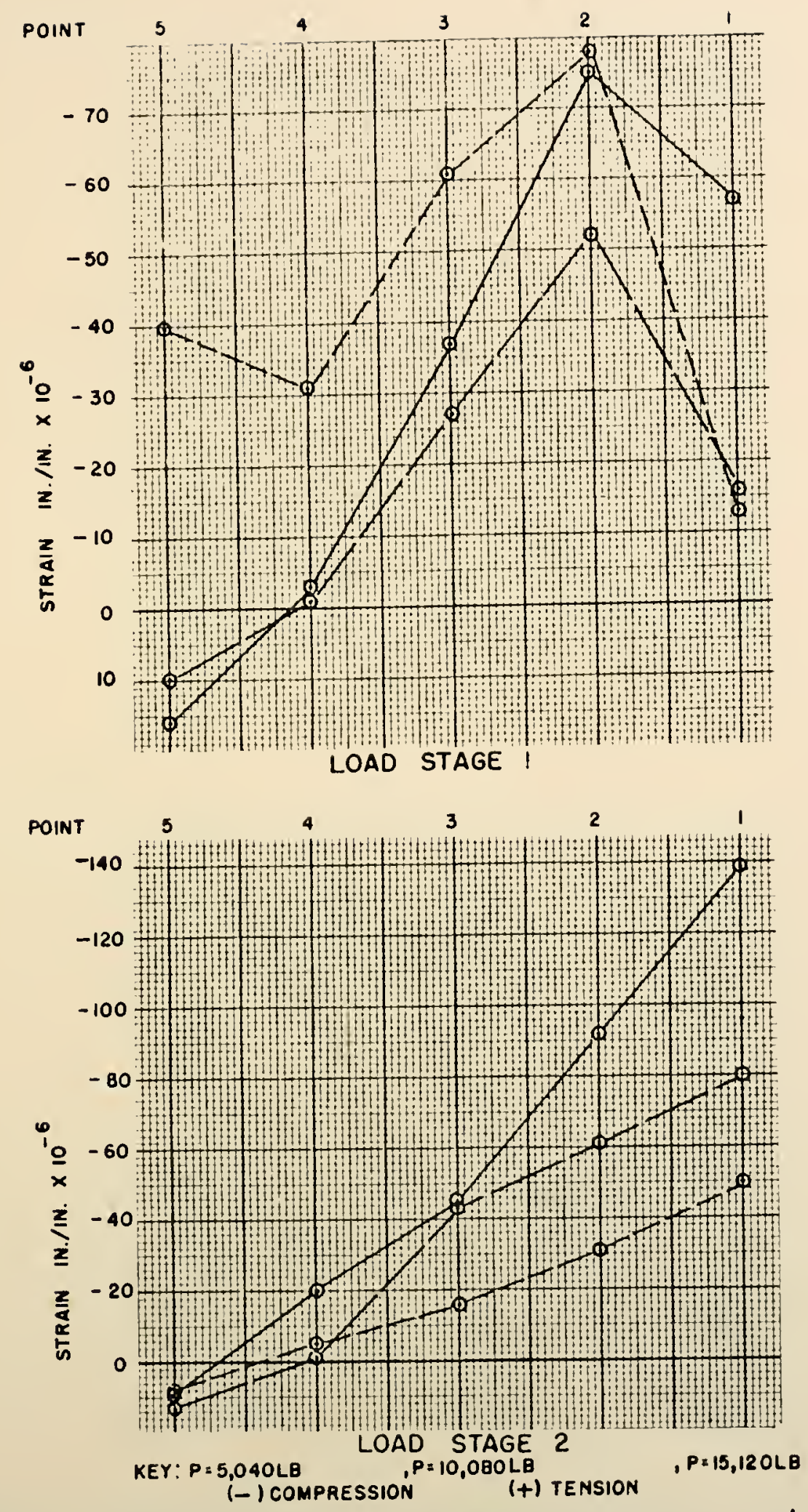

FIGURE 71 . TRANSVERSE TOP SURFACE STRAINS, 8'-0" BEAM SPACING, LOAD STAGES I AND 2 

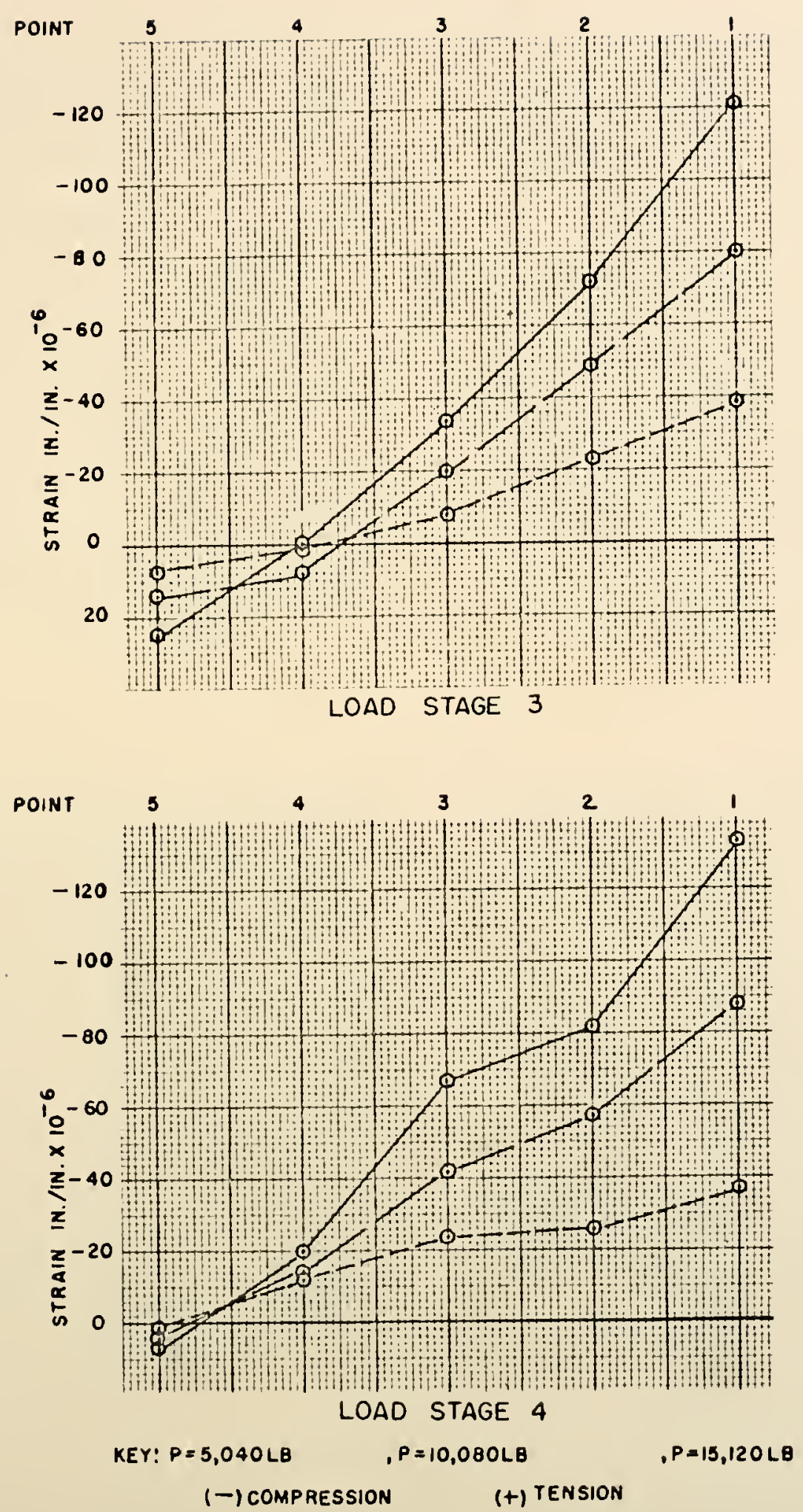

FIGURE 72. TRANSVERSE TOP SURFACE STRAINS, 8'-O" BEAM SPACING, LOAD STAGES 3 AND 4 

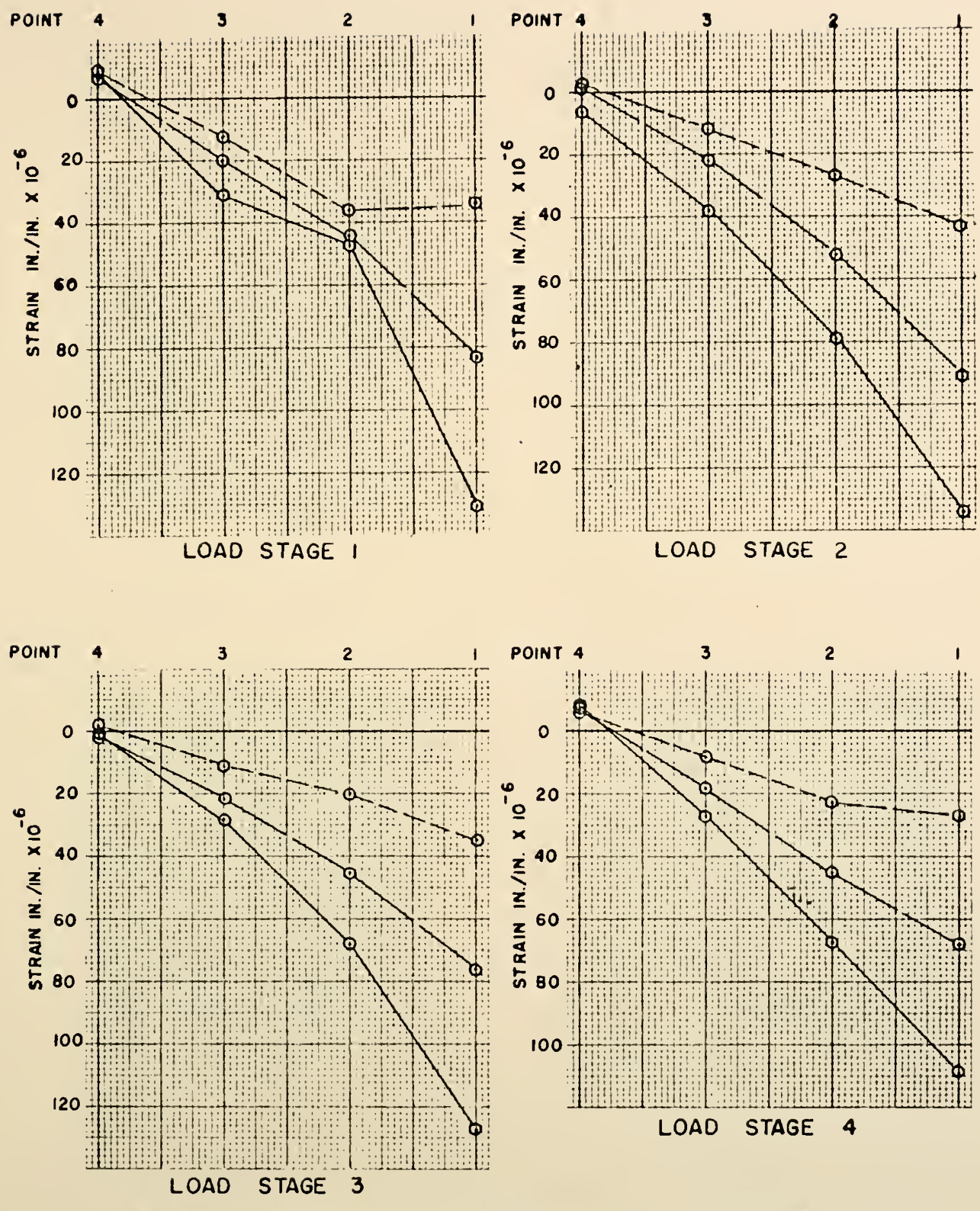

KEY: $P=5,040 \mathrm{LB}-\ldots, P=10,000 \mathrm{LB}$

( + ) TENSION

FIGURE 73. TRANSVERSE BOTTOM SURFACE STRAINS, 8'-0" BEAM SPACING, ALL LOAD STAGES 

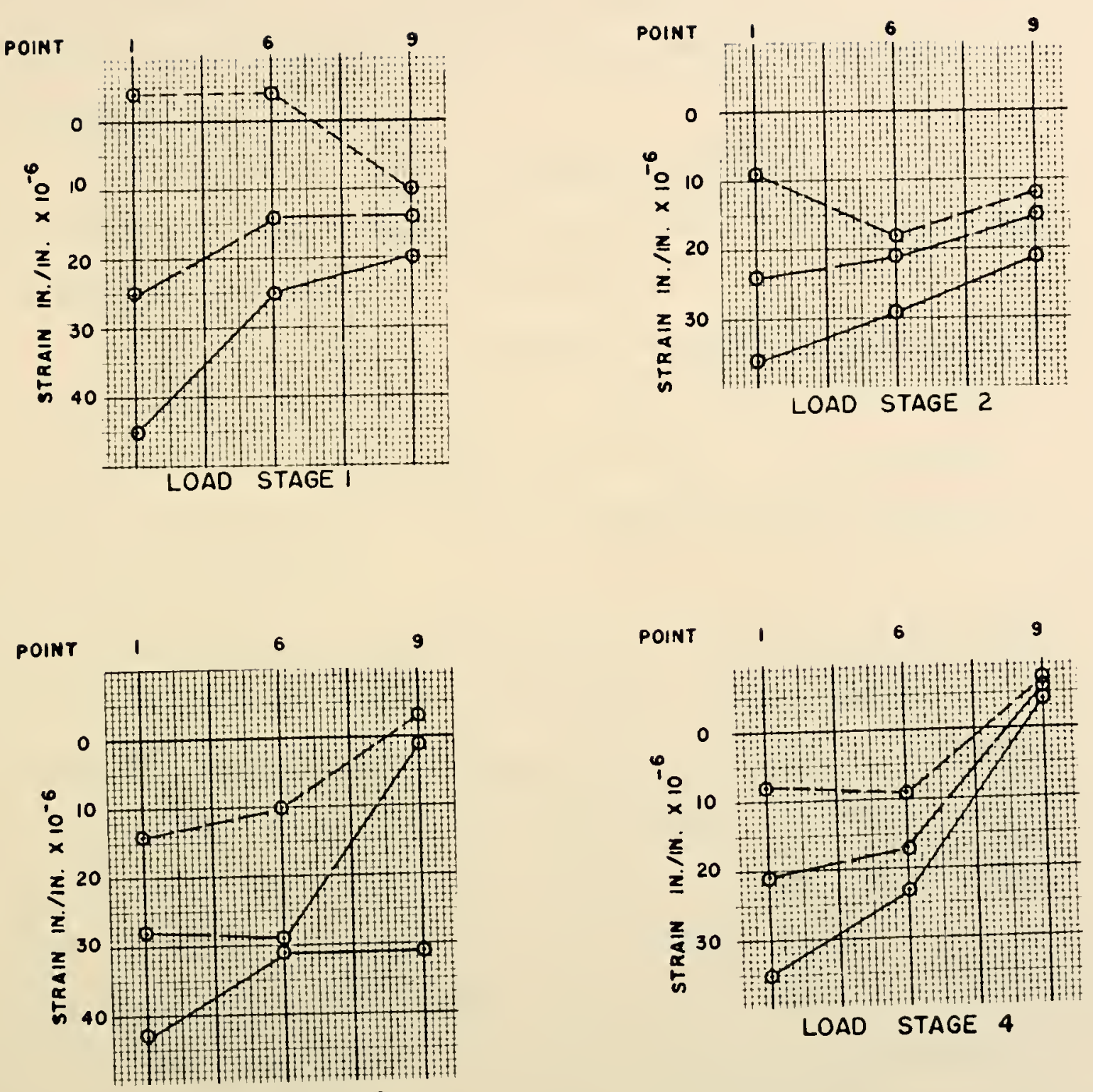

$$
\text { LOAD STAGE } 3
$$

$$
\text { LOAD STAGE } 4
$$

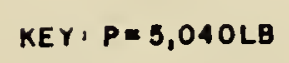

$$
\begin{array}{r}
P=10,080 \text { LB } \\
(+) \text { TENSION }
\end{array}
$$$$
\text { - } P=15,120 \text { LB }
$$

FIGURE 74. LONGITUDINAL STRAIN MEASURED ON LONGITUDINAL CENTER LINE, 8-O BEAM SPACING, ALL LOAD STAGES, TOP SURFACE 
spacing. Contimuty over supports does not appear to be responolble for an lessenting of this phenomenon, as the specimens on 4'-O" beam spacing were essentially continuous and the beams at 8'-on nearly approsimatod a simple support.

Bolting had the effect of lessening deflections by as much as $50 \%$ at the same level of post-tensioning stress. In all cases, bolting decreased the deflection due to applied load.

Strain data indicated participation of sections more than one section distant from the load only to a minor degree. Strain magnitudes were very low on the sections thus located and it is possible that the observed stratns were due to causes other than bending such as a terperature change.

Good agreement was observed botween top and bottom strain gages at the same point in plan and a nearly linear strain distribution through the slab was observed (compare Figures 71 and 72 to Figure 73). This phenorenon would indicate a well manufactured product of unforn or very nearly unfform prestress, unlike the specimens reinforced for 4'-O" beam spacing reported abovo which definitely showed a nonInesity of strain distribution.

Strains shown mas be translated to stresses by multiplying by the modulus of elasticity for the eection of $3.65 \times 10^{6}$ pol.

Using the AASHO equation for Iive load moment IIM $=\frac{s+2}{32} \quad P$ where Is the wheel load. Agatn using the maximum applied load of 15,120 pounds for $P$, IIH $=13,650 \mathrm{ft}-1 \mathrm{~b}$ on the 3 foot sectlon. Stresses become \pm 740 pol contraeted to an observed 447 pol and 464 psi abservod in load stages 4 and 5. This is probably the to the fact that some 
124

continuity is provided by bolting at the support and due to participaion in load carrying by a larger portion of the deck (note the longetuinal center line deflections of Figure 68) than the assumed 3'-on section, indicating a plate action as opposed to a shallow beam action. The applied uniform prestress of 935 psi (compression) is sufficient to maintain the section in compression under applied load. 
TESTING OF PRESTRESSED SPECIIENS UNDER REPEATED IOAD

\section{Repeated Load Test W1th 8'-0" Beam Spacing}

\section{Testing Procedure}

The testing arrangerment for the repeated load test is shown in Flgures 75,76 , and 77 . The supporting beams were spaced at 8 '-0" center-to-center of web and were simply supported with a 20'-0" span on the laboratory floor. The two interior slab sections were reinforced for an 8'-O" beam spacing and the two outside sections were reinforced for a 4'-0" beam spacing. Centers of the load points were spaced at 18 inche8, nine inches on either side of the center joint. Ioad Application. Ioad was applied on alternating sides of the center joint at a rate of 250 cycles per minite to approxdmate the passing of a wheel over the jolnt. The system of jacks used to supply the load is illustrated in Flgures 76 and 77. In Figure 76, Jack 1 was connected to an Amsler Dynamometer with sinich a constant load was maintained. Jacks 2 and 3 were connected to another machine, an Amsler pulsator, which supplied a simusoldally varying load. The pulsator was set with a madmun of $9 \mathrm{kdps}$ and a ndmure of $1 \mathrm{kdp}$ whil the dynamometer was set with a constant load of $10 \mathrm{kdps}$.

Jacks 1 and 2 wero connected with a system of two beams and two rods, as shown in Figures 76 and 77 , in order that the load supplied at the Ioad polnt under jack 1 would be the same as the load rupplied under 


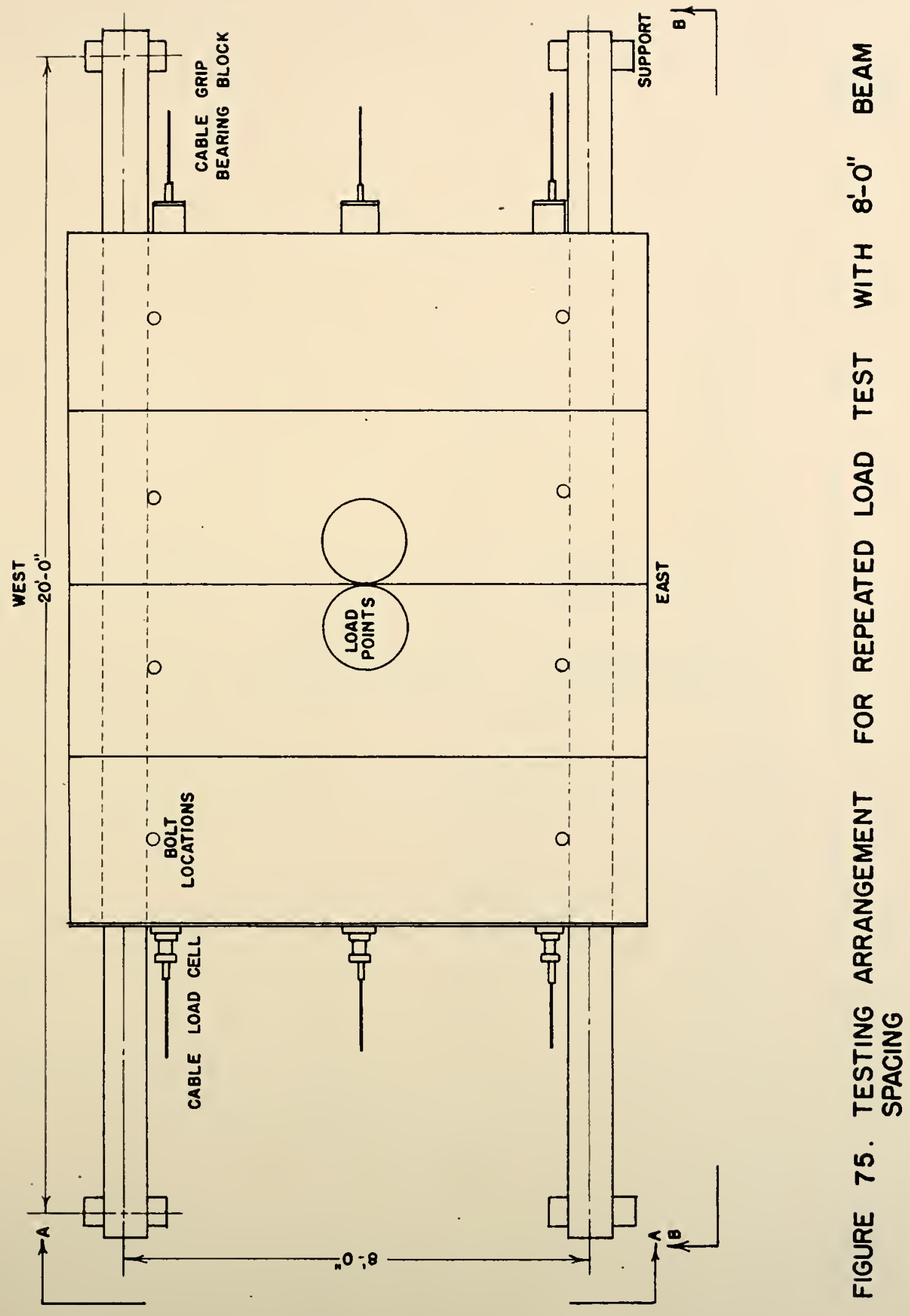




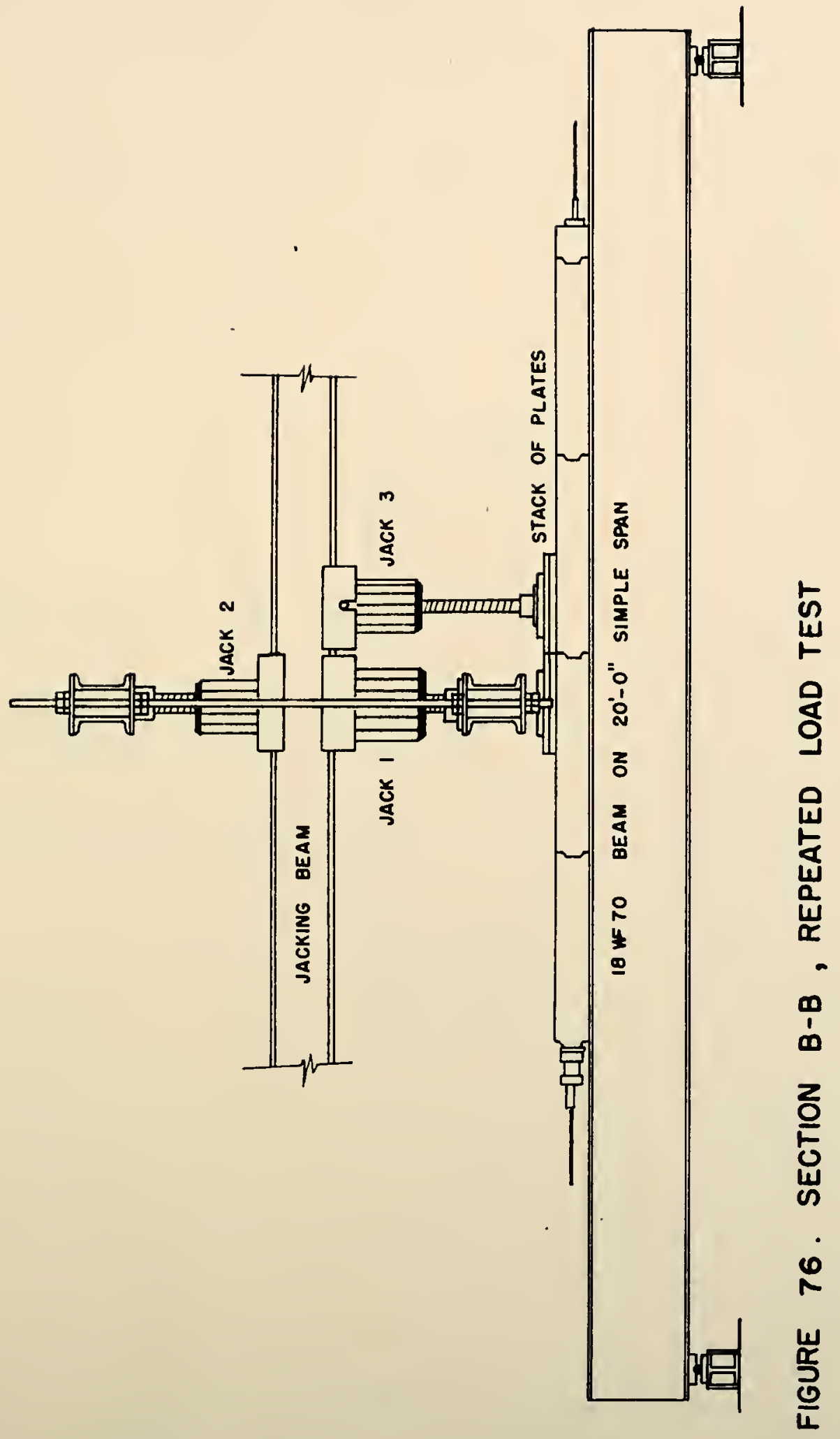




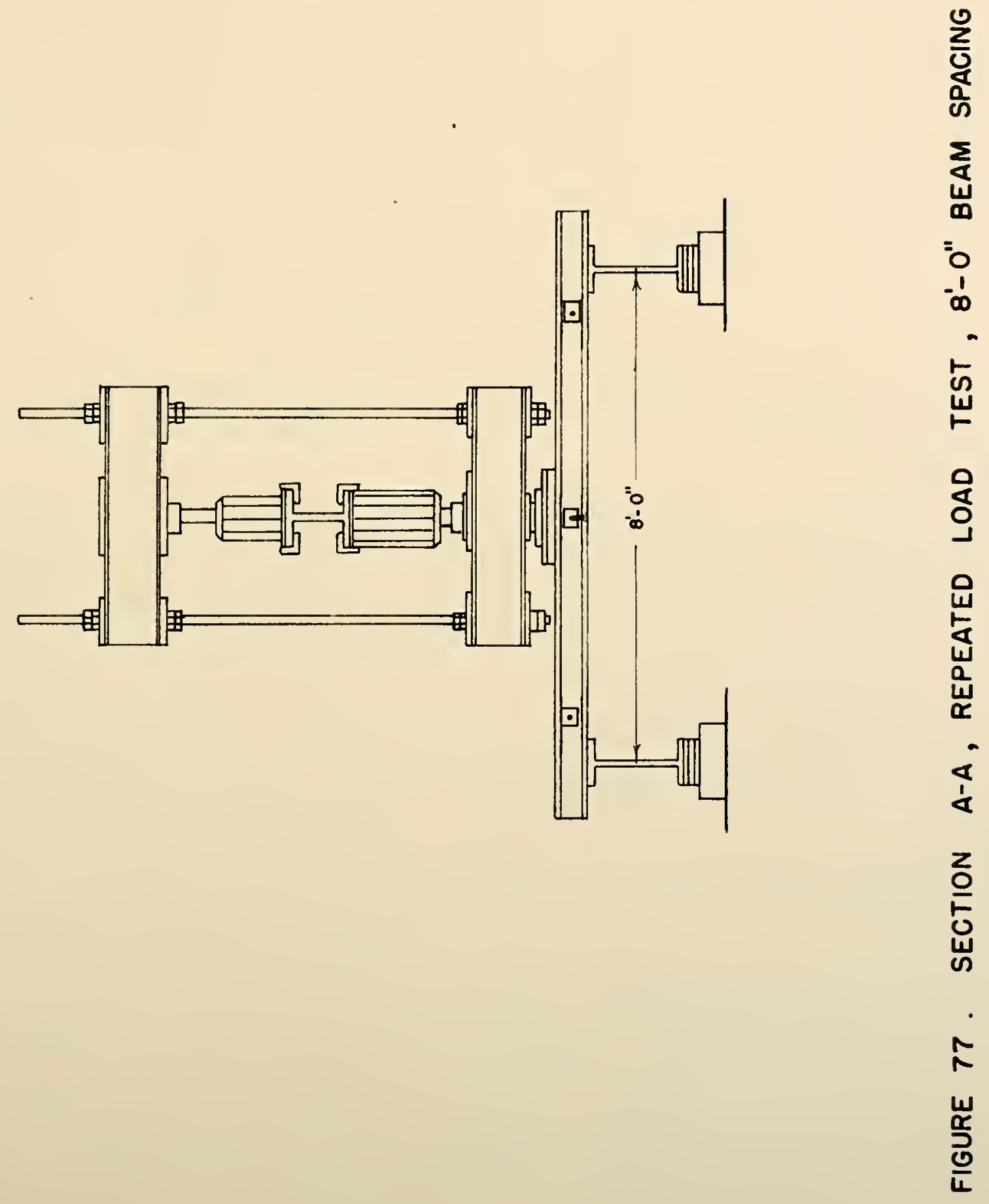




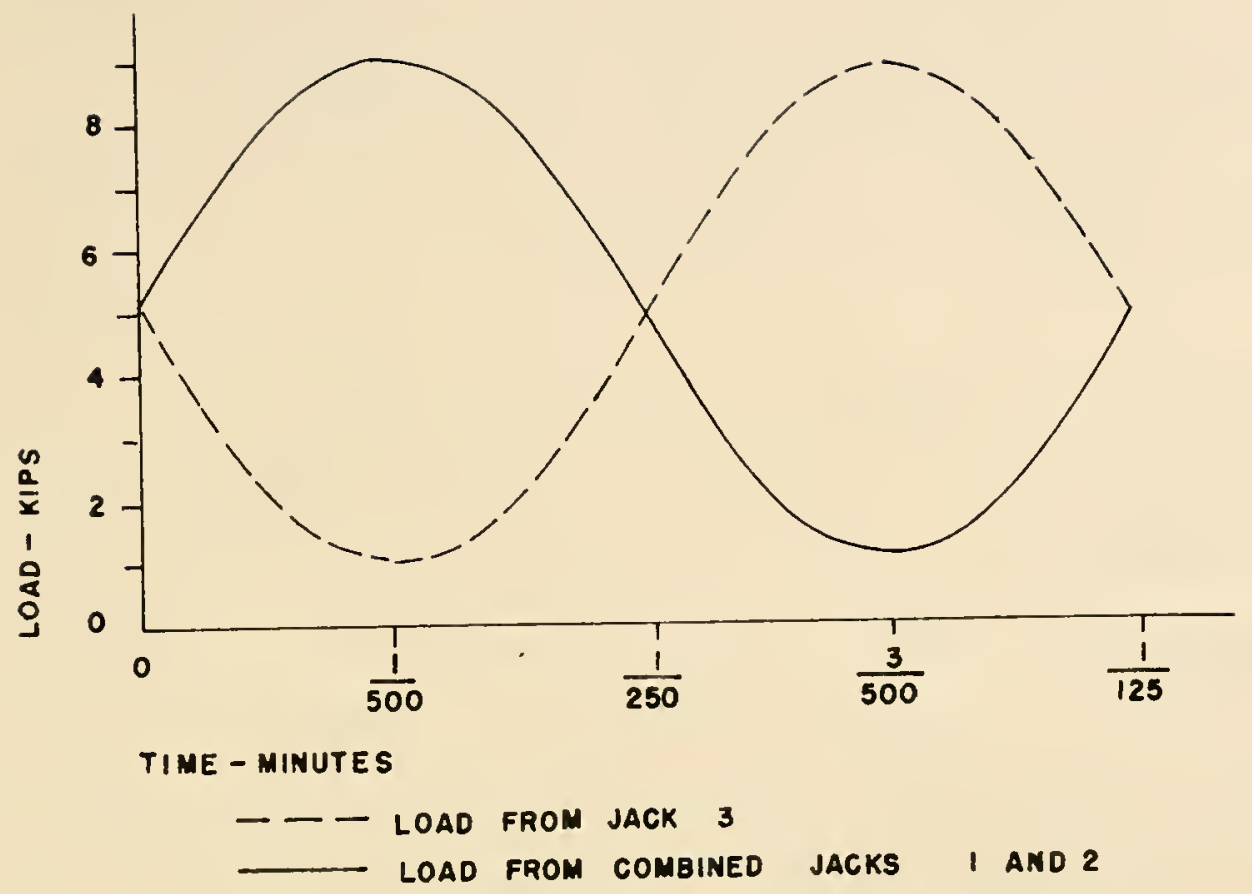

FIGURE 78. LOAD-TIME RELATIONSHIP DURING REPEATED LOAD TEST

jack 3. At the peak of the simusoidal load supplied by the pulsator to jacks 2 and 3 (9 kips), the effoctive loads applied on the slab under jacks $I$ and 3 were $I \mathrm{kdp}$ and $9 \mathrm{kdps}$ respectlvaly (the $10 \mathrm{kip}$ constant load in jack 1 was reduced by the $9 \mathrm{kip}$ load in jack 2 acting in the opposite direction). When the minima load of I klp was supplied to jacks 2 and 3, the loads applied to the slab under jacks $I$ and 3 were $9 \mathrm{kLps}$ and I kip respectively.

Loads were measured by gages which were a part of each machine and were contimuously monitored.

The load point consisted of a stack of steel plates of increasing diameter, the largest diameter being 18 inches. The stack of plates restod on an 18 inch diameter 1 inch thick rubber pad.

Ioads applied to the post-tensioning cables were measured by the 
cable-tension load cells coupled to a strain indicator.

Strain Measurement. Strain gages were used in a one-active-arm Wheatstone bridge circuit, with one adfacent arm of the bridge consistIng of a simflar strain gage mounted on an unstrained concrete cylinder for compensation.

Strain gages were connected to a switch-and-balance unit and the switch-and-balance unit was connected to a portable strain indtcator which supplied power to the brldge circuit. The strain indicator was connected to a strip recorder where the dynamic strain was recorded. The strain indicator, in addition to serving as a power source for the bridge circuit, served as an amplifier for the strain gage signal, and as a calibration instmment for the strip recorder. To make strain readings, the strain indicator was set to zero and activated, and the strip recorder was started. Individual chamel outputs were then recorded on the strlp recorder by switching to the desired chamel on the switch-and-balance wirit.

Strain gage application was similar to that described in the static testing and the locations of the strain gages used are shown in Figure 79. Table 22 contains the strain gage results.

\section{Results}

The test had been in progress for 32,000 cycles of loading when a large spall occurred at the center joint near the west supporting beam. The spall, shown in Flgure 80, was observed to grow along the joint adjacent to the original cracking on the concave side of the jolnt. The cause of the cracking was a combination of several factors, the foremost being a misfit between the joint faces at the point of failure. 


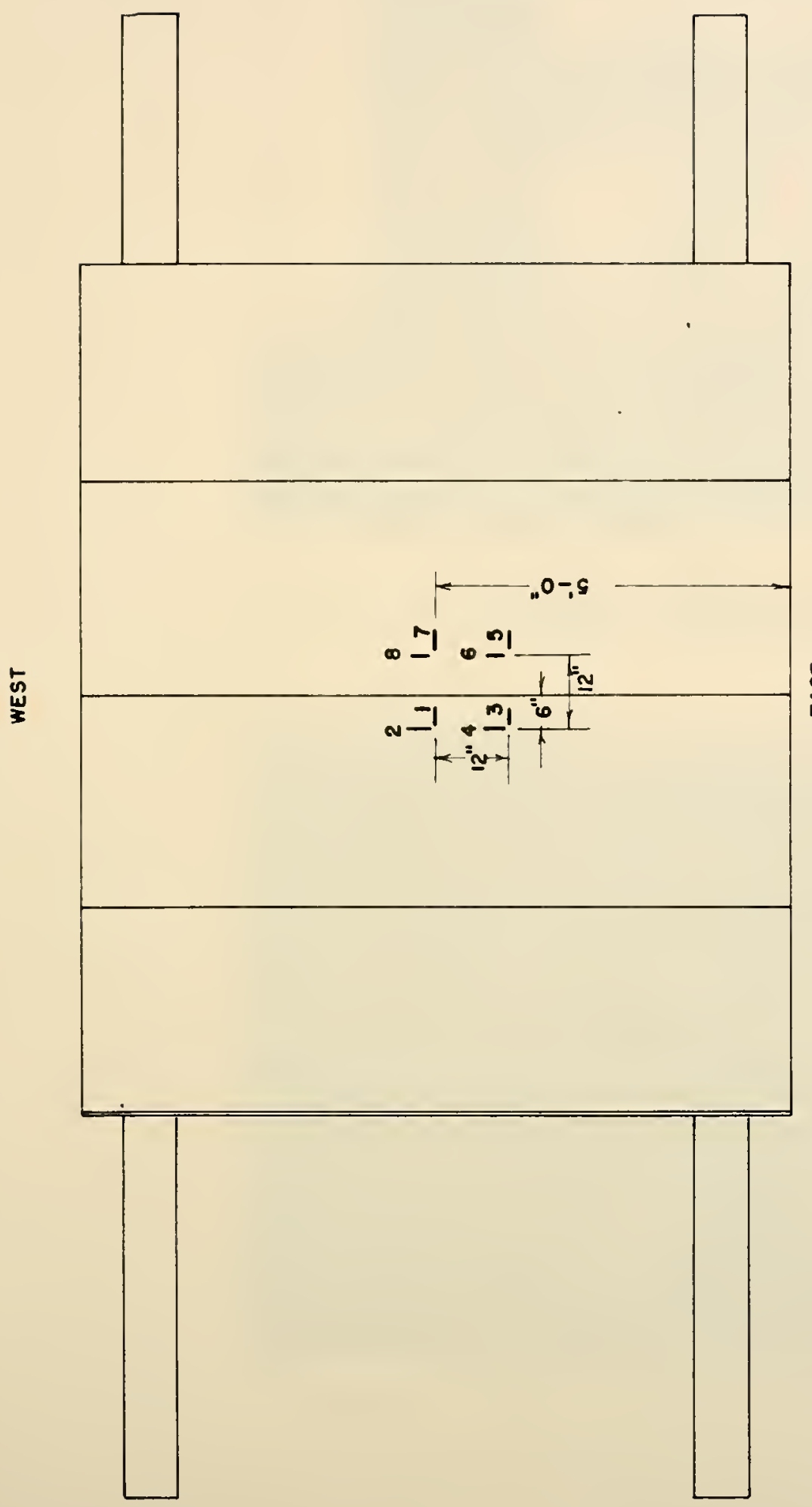

岁恖

0
-1

$I$
5
5
5
5
0
0
0

ํํㅇ ง

ㄴㅇㅇ

5

比

岌崖

중 z

ำ

๖ 宸宸

w

$\infty$

운은

Non

Ni:

$=-$

出出

还或

$\sum_{\infty}^{\infty}$

0

느

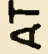

w

峁

号

足

岁

衣这

$\dot{R}$

$\frac{u}{\frac{u}{2}}$ 


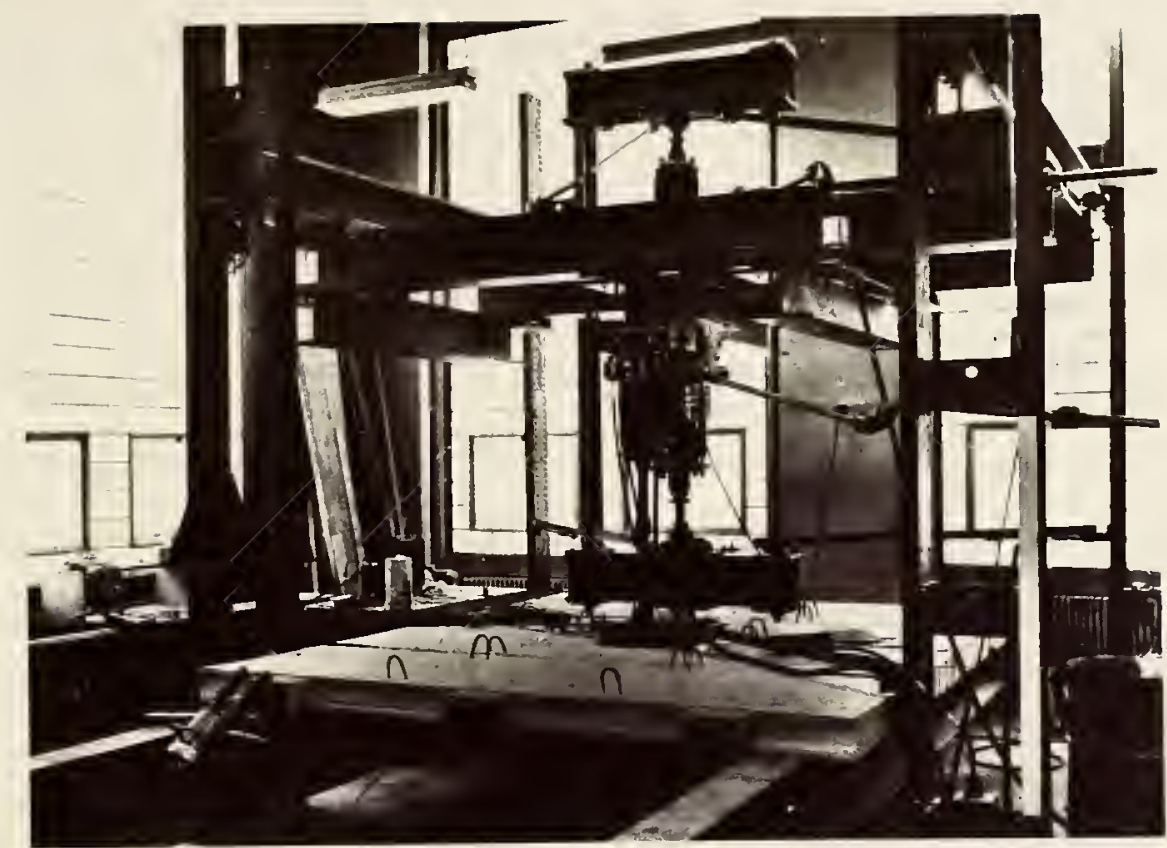

TESTING ARRANGEMENT

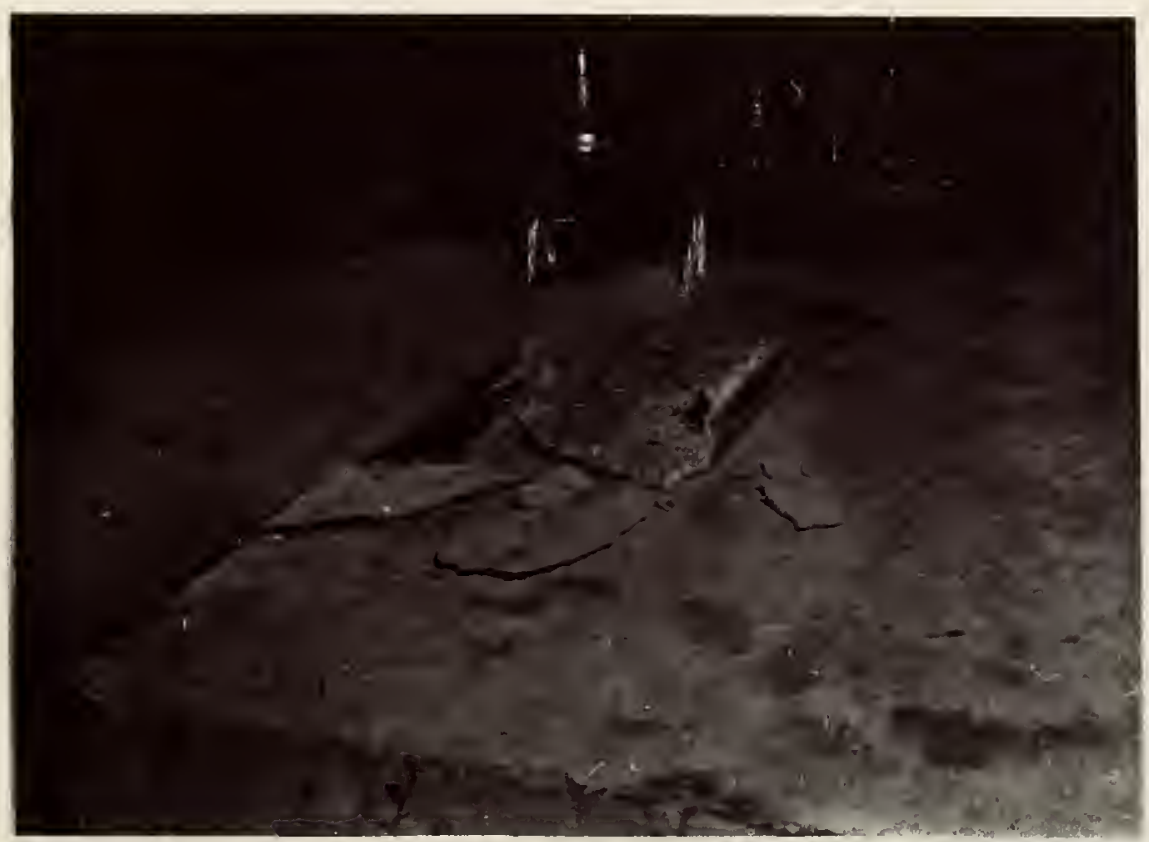

SPALL AT CENTER JOINT

FIGURE 80. REPEATED LOAD TEST WITH 8'-0" BEAM SPACING 
(A complete discussion of the spall appears in the recormendations which follow.) After the spall occurrod, the load in the post-tensioning cable which passed nearly under the spalled area was observed to decrease by 900 pounds, Indicating that after the spall, the adjacent concrete sections moved together and the post-tensioning cable shortened. The average post-tensioning stress on the gross concrete section after the spall was found to be 3 psi less than the stross before the spall. The stress before the spall was $33.3 \mathrm{psi}$ and the stress after the spall was $30.1 \mathrm{psi}$.

The test was discontimed at 715,000 cycles of loading; no further cracking was observed after the cracking at the "spall stopped.

Strains remained nearly constant throughout the test and no pattern of increase or decrease in strain due to fatigue was noted.

Testing was begun again with the supporting beams spaced at 4'-6" with the sections reinforced for 8'-0" beam spacing again in the center but interchanged with regard to location. This served to ramove the spalled area (from the first test) from the location of the center critical joint and permitted a re-examination of the joint.

\section{Repeated Load Test With 4'-6" Boam Spacing}

Thlo test was identical to the provious test with the exception of supporting beam spacing (4'-6" r.s. 8'-0"'), strain gage locations (see Plgure 81), and an interchange of location of the center two deck sections.

Strain gage readings, loacting, and load measurement were accomplished as in the previous test. The strain gage locations are illustratod in Figure 81 and strain readings appear as Table 23. 


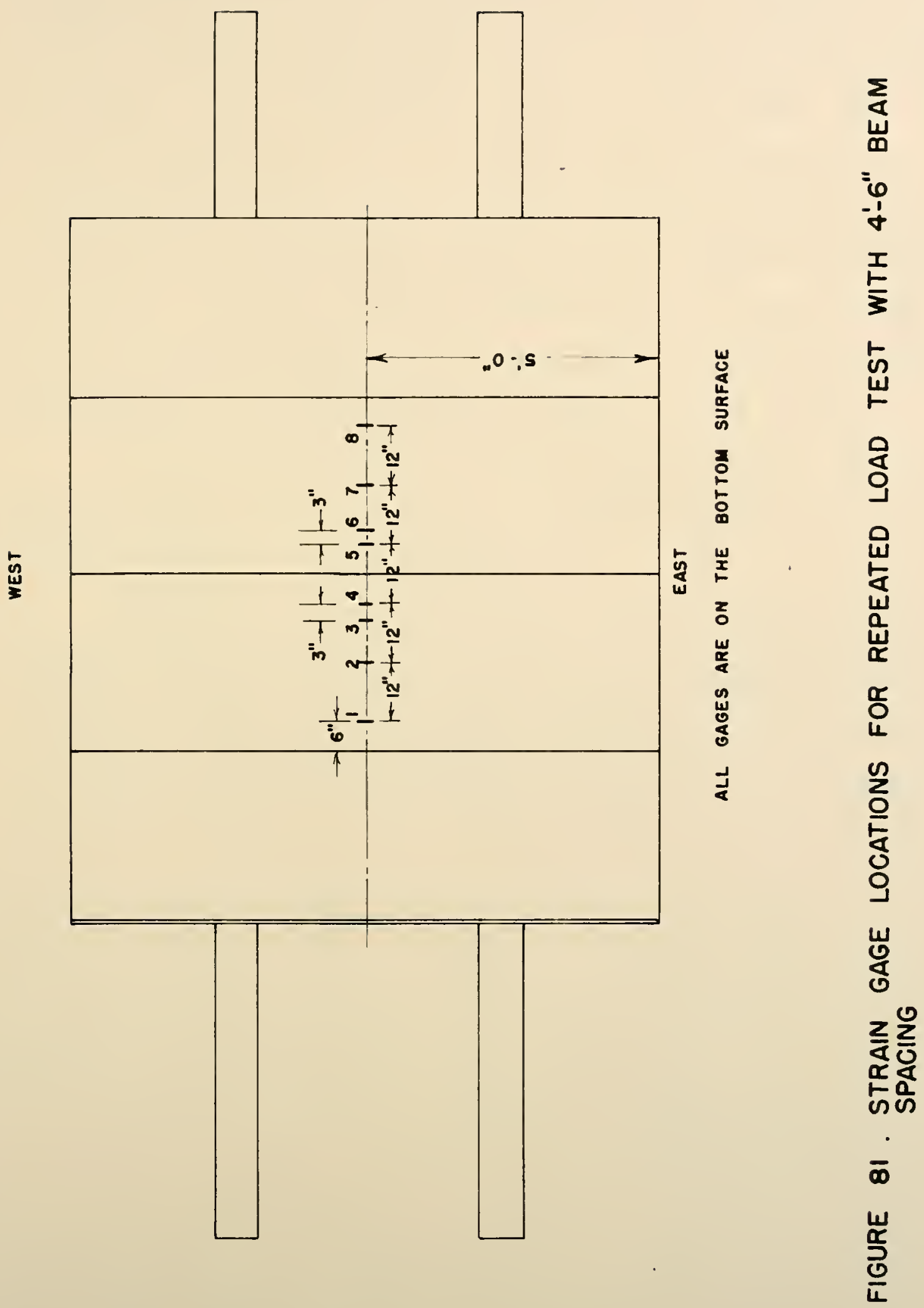


In this test, no cracking or other fallure pattern was observed through nearly two million cycles of repeated load. Therefore, since the post-tensioning stress level on the gross concrete section was maintained at $32 \mathrm{psi}$, nearly the same stress as in the prevlous test, it would confirm that the spall of the previous test occurred dus to a disconformity at the location of the spall. Although there was not as much deflection between adjacent sections due to a smaller beam spacing, it should be noted that the spall of the previous test occurred under one of the post-tensioning cables very near one of the supporting beams where there was very little deflection botween adjacent sections.

Strain magnitudes did not increase or decrease appreciably over the two milition cycles of loading and the post-tensioning stress level remained constant throughout the test.

Although the test conflrmed that full-face bearing with a wellfltting joint could perform satisfactorily, it is strongly felt that an improved overall performance can be realized by modiflcation of the joint shape. The proposed modiflcation is presented in the recomendations whych follow. 


\section{COST ANALYSIS}

\section{Precast, Prestressed System}

The cost of a typical bridge deck has been estimated by Construction Products Corporation of Lafayette, Indiana. The co at estimate was based on a $4^{\prime}-0^{\prime \prime} \times 6^{\prime \prime} \times 32^{\prime}-0^{\prime \prime}$ section reinforced for a beam spacing of 8'-0", erected in place. The sum of $\$ 3.76$ per square foot of deck surface does not include fleld labor for bolting or other operations performed in the field.

Estimates for the associated materials are made as follows: post-tensloning, 2.5 cents per square foot; tie-downs, 8 cents per square foot; joint material, 8 conts per square foot. The total cost of the deck is estimated at approxdmately $\$ 3.95$ per square foot of deck.

\section{Reinforced Concrete System}

A cost estimate for a conventionally reinforced concrete deck was made using constmuction estimates and itemized proposals supplied by the Indiana State Highway Commission. An estinate for the concrete cost was made using an 8" deep deck, and a unit cost of $\$ 140.70$ per cuble yard of concreto. Reinforcing steel was estimated at 275 pounds per cubic yard and 18 cents per pound. Total estimated coot $1 . \$ 3.52$ per square foot of deck surface. 


\section{Cost Compartson}

The cost estimates made above are not assumed to be the actual cost at which either. system could be constructed as neither cost eat1mate 1. based on a completed stmeture. However, it is believed that the costs represent a reasonable estimate. Neither cost estimate allows for construction of any item other than the concrete deck within the span of the bridge. The cost of approach pavenent and other items would vary depending upon the particular application.

The cost of the precast, prestressed deck appeare to bo the most expensive method when one considers only the cost of construction. The cost estimate for construction of the preatressed system is approdimately 12 percent higher than the estimate for the conventionally reinforced system. This may be milleading since the producer of the prestressed deck 18 not experienced in manufacturing the product on a large scale. Experfence on the part of the producer could reduce the cost of construction as the majority of the construction cost is reflected in his estimate for precasting.

The short down-time of a bridge for deck replacement using the precast system may easily make the precast system the most economically feasible. At least one month could be sared with each application of the precast system since reinforced concrete would require curing of nearly a month after it was in place on the bridge.

The cost of the precast deck systen is not only competitive with a reinforeed concrete deck but is possibly the most attractive when one considers the element of tire. Included in any cost analysie must also be the projected life of the structure. The planned ouperlor durabllity 
of the precast deck should provide a longer service life with resulting economy than a cast-in-place deck.

Additional economy may result in replacement of the precast deck. Worn or deterforated sections may be roplaced individually and quickly, with no time lag for forming or curing of concrete. 
CONCLUSIONS

A prestreseed concrete deck oystew which was designed according to the 1965 standards set by the American Association of State Highway Officials has been examined under a static load and under a repeated load in the laboratory. The testing indicated that the design procedure using the limiting parameters established by the 1965 AASHO specifications are adequate and conservative. Bending stresses under stat1c loading approached but did not in any case exceed the stresses which would be predicted using the guidelines enumerated in the speciflcations when the deck system was arranged in the planned prototype conflguration.

The results of the testing indicated that precasting can produce a deck of sufflcient amoothness if proper care is exercised during casting. Dimensional control, espocially at the jolnt face, was the largest single problem that wa encountered. The laboratory investigation indicated that even rery slight dimensional frregularities at the jolnt face would cause spalling upon post-teneloning; this led to recommendIng a slight modiflcation in joint shape to alleviate the problem. Whereas full-face bearing was attempted at the joint, it is now believed that bearing on the flat center half of the joint would be oufficient. Examination of a photoalastic modal conflimed that this would be acceptable and would not cause problems due to stress concentrations.

The handware used to mechanically tie the precast deck to the supporting steel beams performed satiafactorily. Untimate capac1ties 
of the bolting system were examined by others ${ }^{4}$ and found to be substantially above the working load level anticipated in this application. The design of the prestressed sections was made under the assumption that a wheel load would be carried by one section. This assumption was found to be basically accurate. Stmulated whoel loads were carried by the loaded section with little interaction or load carrying from adjacent sections. Some insigniflcant interaction between adjacent sections, a plate action, was observed for the largest beam spacing.

The precast deck is competitive on a cost besis with a cast-inplace deck. Although construction costs may bo slightly higher for the precast deck, the short down time for implementing the oystem as vell as possible cold weather construction should make the precast deck economically attractive.

This constitutes the inftial work in a continuing study of the precast, prestressed concrete bridge deck concept which will culminate in the construction of a monitored prototype. 
RECOIMENDATIONS

- Some diffleulty was encountered in the laboratory with joint surfaces which did not fit properly on the prestressed specimens. Mose inspection and careful casting cannot relleve all of the dimensional irregularities but should minimize them. The problem lies in joint performance due to improper flt.

In several cases, corners of the concave face of the joints were broken of 1 , due to both post-tensioning and bolting. In the case of post-tensioning induced fallure, the larger convex surface could not be accommodated by the smaller concave surface and the post-tensioning force caused the convex ourface to act as a wedge, forcing the corners of the concare face to spall off. The bolting caured the same type fallure but always on the top surface of the concave foint face. Here, the concrete cracked due to a relative movement between two adjacent pieces as the bolts were tightened. Here, again, the problem is attributed to misft.

The spall in F1gure 80 was observed to occur under repeated load when the supporting beams were at 8'-0" centers. Upon examination of the spalled area, it was evident that several conditions contributed to the spall. First, and foremost, there was evidence of improper fit. The neoprene foint material had apparently been under high pressure at. the point and left a distinct color impression on the high points on the spalled joint face. Secondly, the neoprene matertal had alipped 
approximately one inch at this location and may have contributed to the cracking by causing an uneven bearing. The spall occurred directly above one post-tensioning cable, a factor which coupled with the mevenness at that point would hasten trouble. Under the action of the repeated load, the relative motion between the slabs cannot be overlooked as a contributor to the spelling.

Fallures of the aforementioned type cannot be tolerated. It is apparent that full-face bearing at the joint is practical but not the most desired configuration. Rather, if bearing at the joint was linited to the flat, center portion of the joint, stresses at the joint would be approxdmately doubled (a tolerable circunstance) and the contributors to cormer break-off, the only type fallure that was observed, would be eliminated. The portions above and below the flat, center part of the joint could be cut back on both sides of the joint with closure of the joint provided by a joint material of sufficlent (probably varying) thickness.

The flat joint photoelastic study was conducted wi th a joint shape of nearly this conflguration (see Flgures 17, 18, and 19) and only minor tension stresses were encountered.

It is further rocommended that the top edge of the joint be tooled to a small-radius cormer after casting. Without this shape, trafflc would probably 1rregularly break off the square corner.

It is recommended that the modifled foint shape be subjected to a test similar to the repoated load test reported herein. The modifled joint shape is shown in Flgure 82. The strand and insert patterns are illustrated in Figures 29 and 26. The same strand pattern could be 


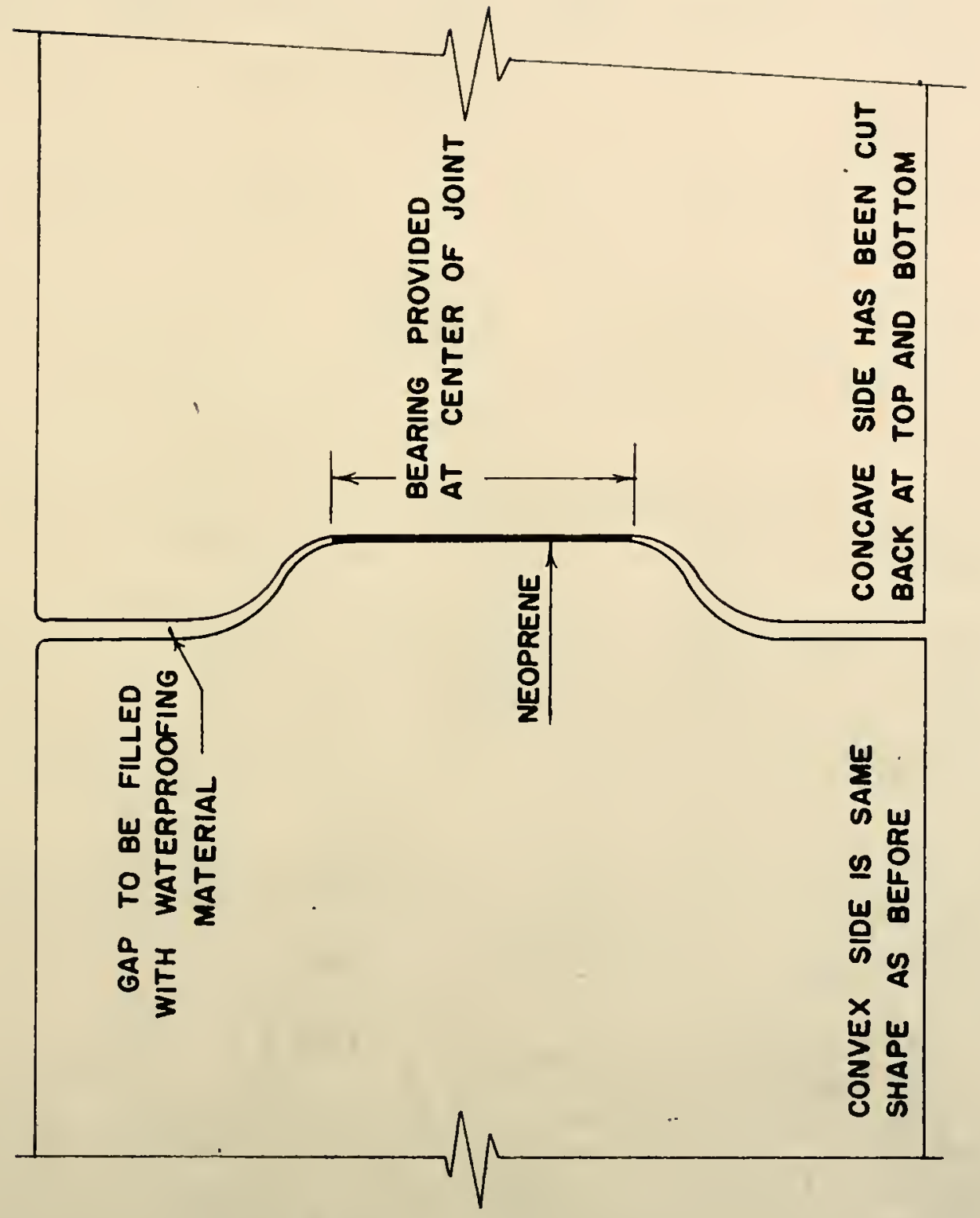

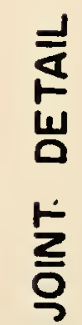

4

은

嵌

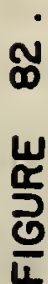


used in all sections (12 - 7/16 in. dlameter - 270k strands) for econougy.

A test of some or all of the prestressed sections to failure in flexure is recommended to examine the ultimate flexural capacity of the designed sectlons. Comparison to the theoretically determined ultimate flexural capacity reported herein would be of value. 


\section{BIBLIOGRAPHY}

1. Dally, James W. and WHIlian F. Pdley. Experimental Stress Analysis. New York: McGraw-Hill Book Company, 1965.

2. Faupel, Joseph H. Engineering Design. New York: John Wiley and Sons, Inc., 1964, pp. 953-954.

3. Harvard, David G. "Photographtc Display of Stress Directions in Plane Photoelesticity," Experimental Mechanics, September 1957, pp. $407-408$.

4. Hsu, T. T. C. and Noman W. Hanson. "An Investigation of Ra1lto-Concrote Fasteners," Journal of the PCA Research and Development Laboratories, Portland Cement Association Vol. 10, No. 3, September 1958, pp. 14-35.

5. Perry, C. C. and H. R. Lissner. The Strain Gage Primer. New York: MeGraw-IHIl Book Company, Ine. 1962.

6. Specifications for Design, Materials, Construction of Prestressed Concrete Tles Revised October 27, 1967. (Obtained in personal correspondence wh th $\Sigma$. J. Fuble, Execut1ve Research Inglneer, Association of American Railroads).

7. Standard Speciflcations for Highway Bridges. Washington, D. C.: American Association of State Highway officials, Ninth Bdition 1965 .

8. Whitney, C. S. "Design of Reinforced Concrete Members Under Flexure or Combined Fexure and Compression," Proceedings, American Concrete Institute, Vol. 33, 1937, pp. 483-498.

9. Cra1g, Robert John. "Bridge Slab Joint Connection Study," Unpublished Report. 
APPENDIX A 


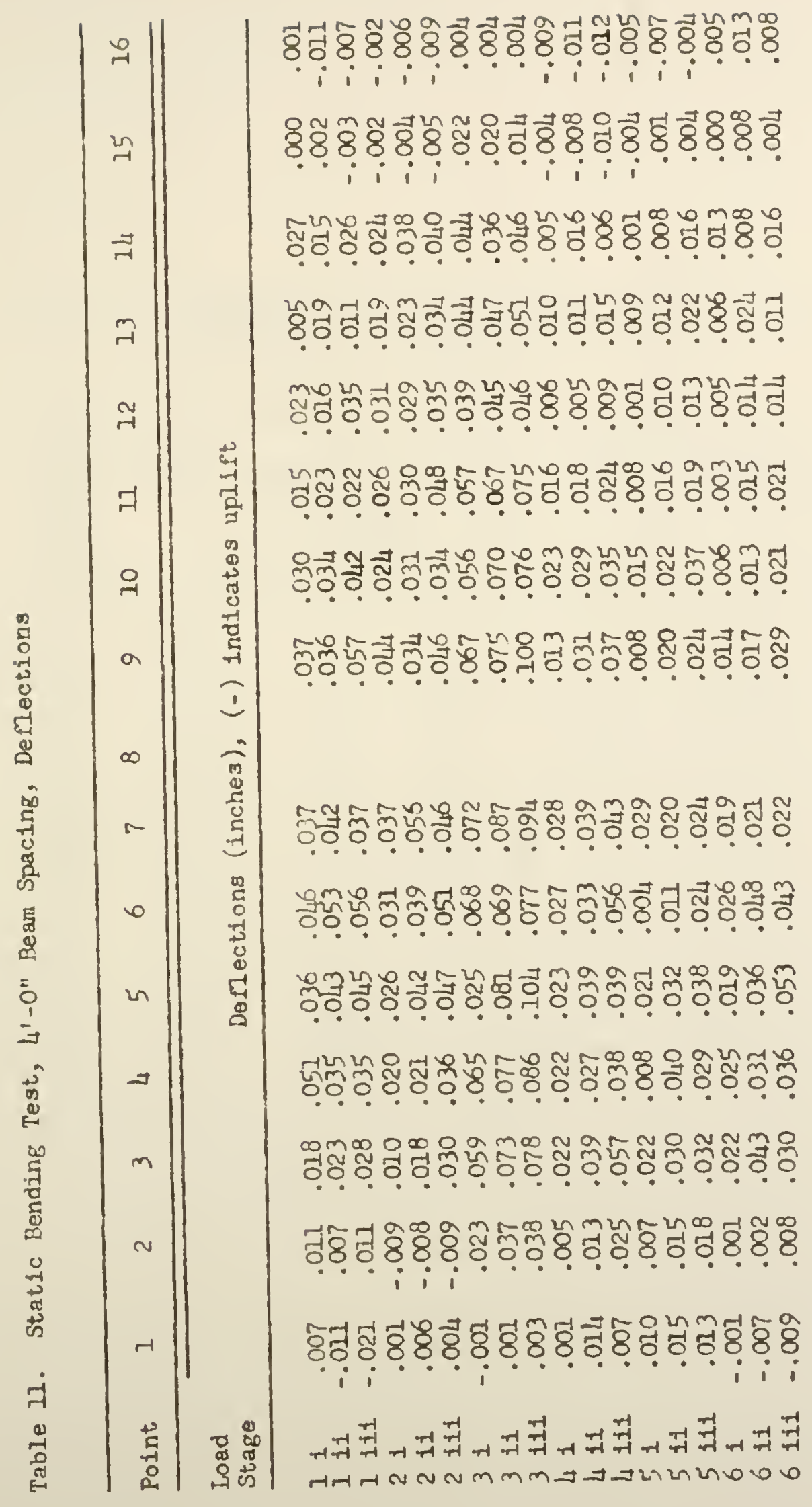


Table 12. Strain Data, 4'-O" Beam Spacine Static Test, Top NorthSouth Gages on Section 4-2

\begin{tabular}{|c|c|c|c|c|c|c|c|c|c|c|}
\hline Gage & 1 & 2 & 3 & 4 & 5 & 6 & 7 & 8 & 9 & 10 \\
\hline $\begin{array}{l}\text { Inad } \\
\text { Stage }\end{array}$ & & St $x$ & 1 & $\times 10$ & $(-)$ & compr & sion, & $(+)$ & tenst on & \\
\hline 11 & 5 & 2 & 6 & 2 & 0 & 10 & 7 & 8 & -13 & 6 \\
\hline$I$ ii & 16 & 11 & 20 & 12 & -5 & 10 & 11 & $1 ?$ & -10 & 15 \\
\hline$I i 1 i$ & 23 & 18 & 32 & 22 & -12 & 24 & 3 & 24 & 5 & 19 \\
\hline 21 & 3 & 0 & 6 & -15 & -8 & 11 & 1 & 8 & 5 & 11 \\
\hline 211 & 3 & 7 & 20 & -10 & -8 & 27 & 11 & 5 & 16 & 15 \\
\hline $2 i l i$ & 6 & 10 & 25 & -3 & -11 & 25 & 15 & 10 & 4 & 16 \\
\hline 31 & -1 & 3 & 10 & -36 & -14 & 0 & 6 & 0 & 3 & -2 \\
\hline 3 is & -3 & 5 & 15 & -34 & -23 & 7 & 9 & 7 & 0 & 1 \\
\hline $31 i$ & -2 & 5 & 23 & -35 & -25 & 19 & 18 & 21 & 6 & 3 \\
\hline 1. 1 & 5 & 6 & 6 & -10 & -7 & 12 & 5 & -5 & 2 & -1 \\
\hline i 11 & 0 & 5 & 11 & -20 & -15 & $1 i$ & 8 & 3 & -5 & 0 \\
\hline $411 i$ & 6 & 12 & 19 & -19 & -20 & 25 & 15 & 3 & 8 & 4 \\
\hline 51 & 0 & 3 & 10 & -5 & -2 & 11 & 8 & 8 & 10 & 2 \\
\hline $5 \mathrm{ii}$ & -4 & 3 & 15 & -12 & -10 & 21 & 12 & 8 & 4 & 3 \\
\hline 5111 & -11 & 3 & 13 & -12 & -14 & 19 & 15 & 11 & -2 & -5 \\
\hline 61 & 5 & 7 & 14 & 3 & -4 & 4 & -1 & 4 & -2 & -2 \\
\hline $6 i i$ & 2 & 7 & 19 & 3 & -6 & 5 & 1 & $\overrightarrow{11}$ & -3 & 2 \\
\hline 6 iii & 9 & 6 & 28 & 5 & -1 & 1 & 4 & 12 & -1 & 2 \\
\hline
\end{tabular}


Table 13. Strain Data, 4'-0" Beam Spac1ng Static Test, Bottom NorthSouth Gages on Section 4-2

\begin{tabular}{lllllll}
\hline Gage & 2 & 3 & 4 & 7 & 8 & 10 \\
\hline
\end{tabular}

Ioad Stage Strain $\left(\frac{\text { in }}{\text { in }} \times 10^{-6}\right) \quad(-)$ conpression, (+) tonsion

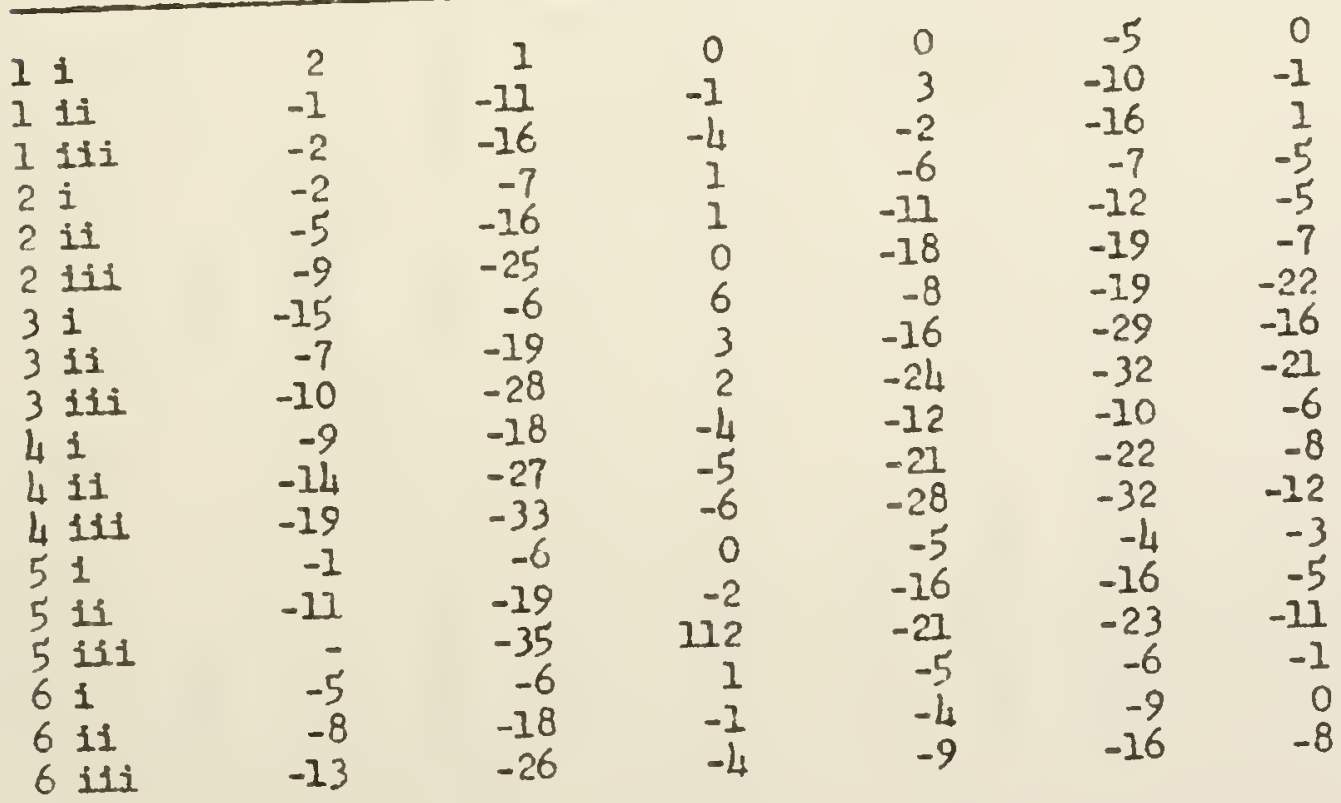


150

Table 14. Strain Data, $4^{\prime}-0^{\prime \prime}$ Beam Spacing Static Test, Top East-West Gage on Section 4-2

\begin{tabular}{lllllllllll}
\hline Gage & 1 & 2 & 3 & 4 & 5 & 6 & 7 & 8 & 9 & 10 \\
\hline
\end{tabular}

Load $\quad$ Strain $\left(\frac{\text { in }}{\operatorname{In}} \times 10^{-6}\right) \quad(-)$ compression, $(+)$ tension
Stage

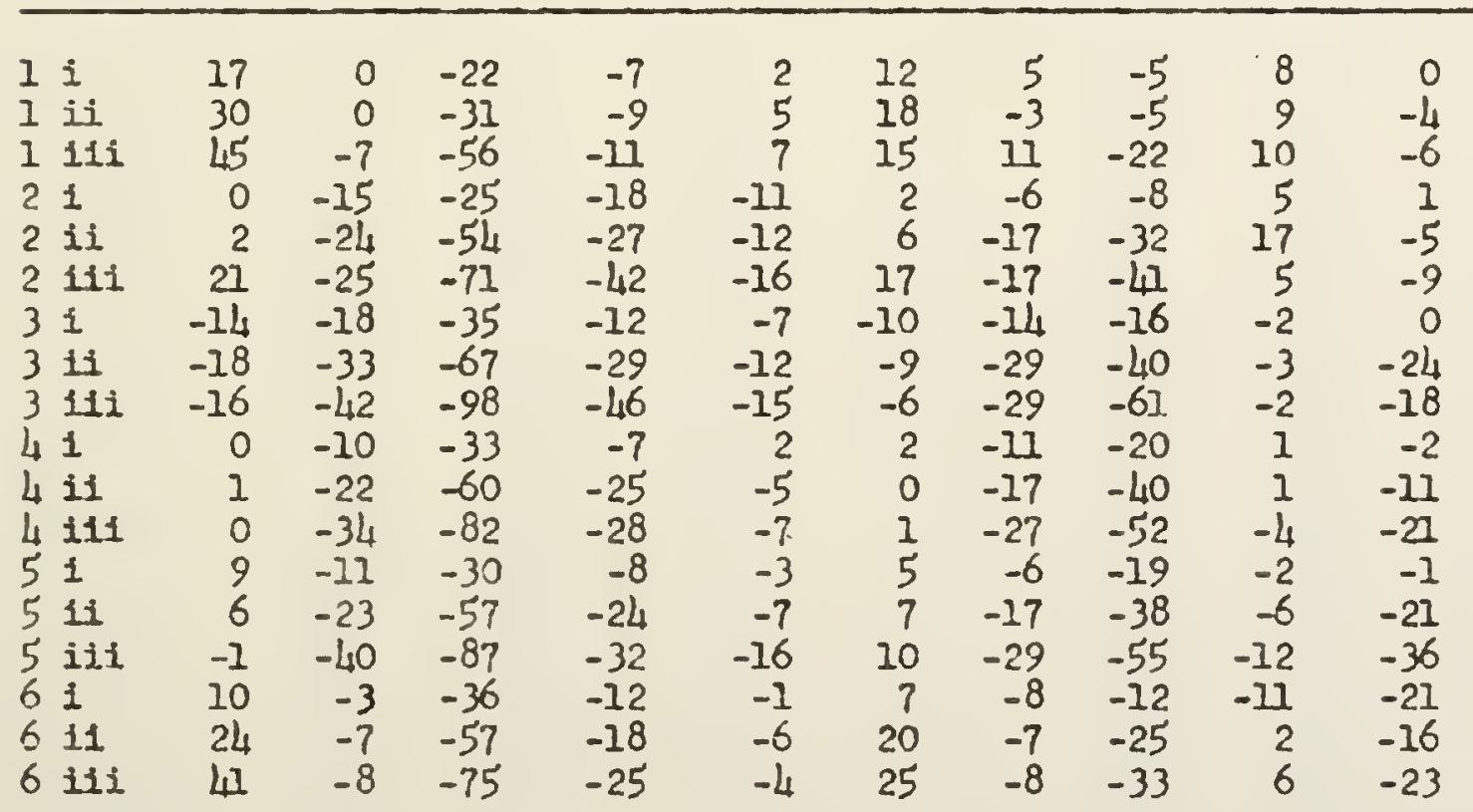


Table 15. Strain Data, 4'-0" Beam Spacing Static Test, Bottcm EastWest Gages on Section 4-2

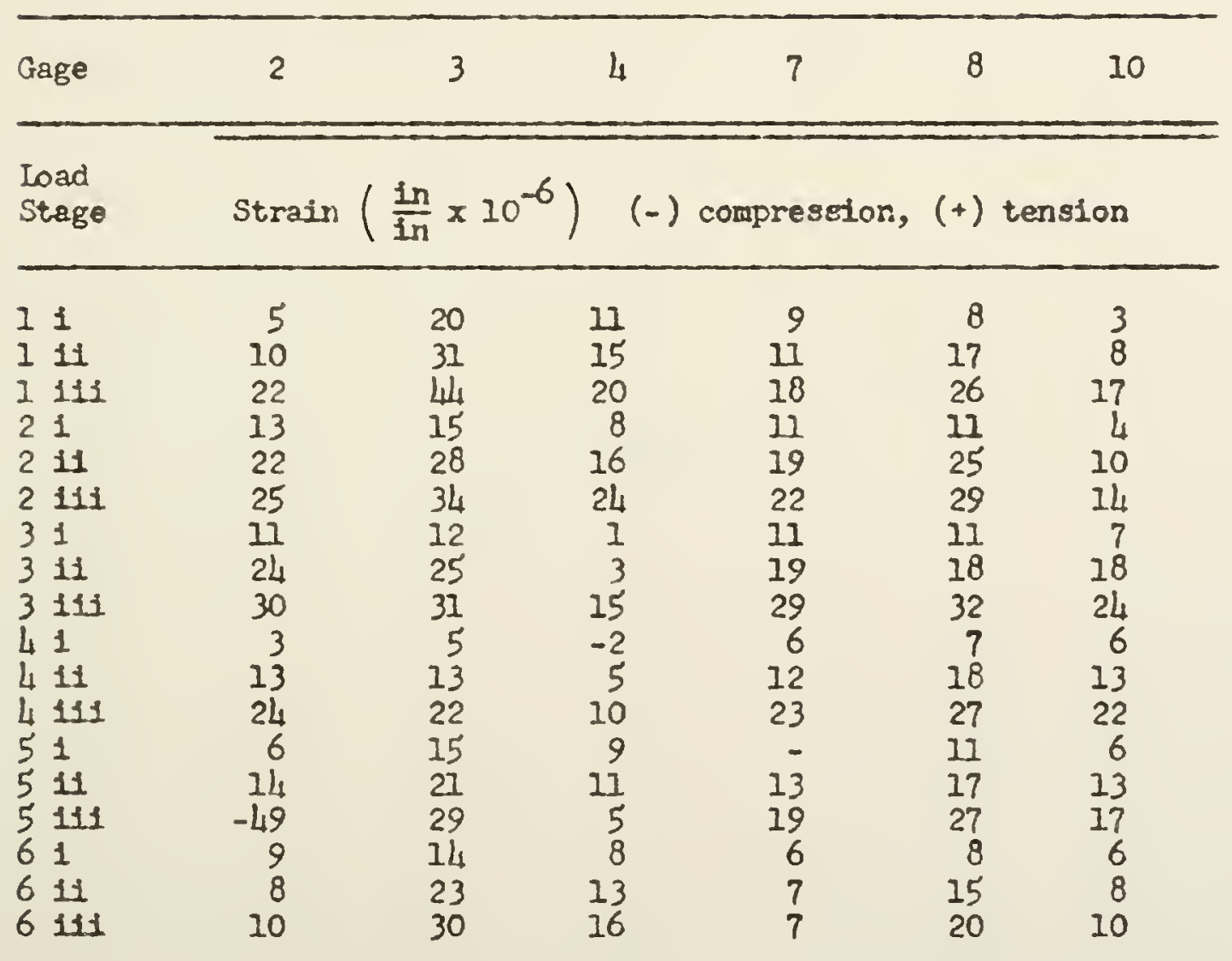


APPENDIX B 


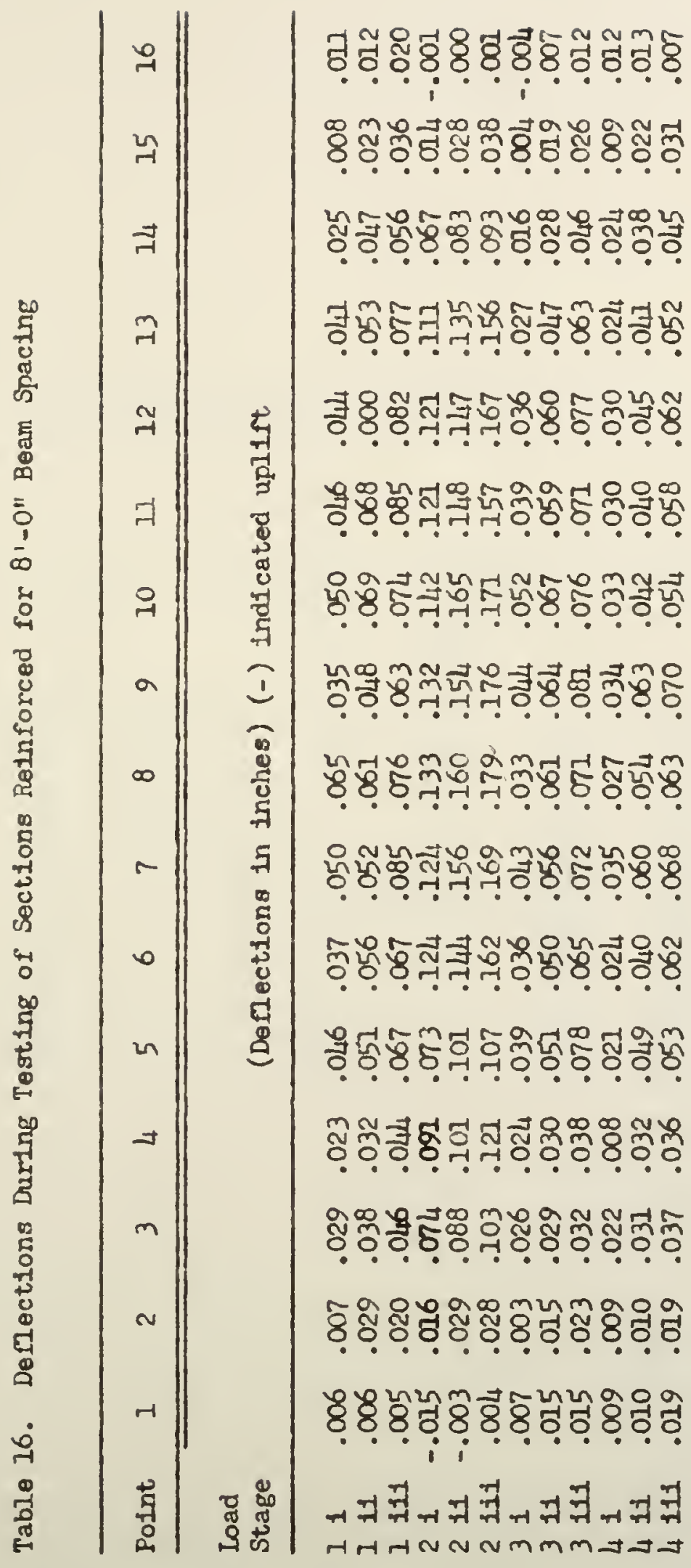


Table 17. Strain Data, 8'-0" Boam Spacing Static Test, Top East-West Gages on Section 8-1

\begin{tabular}{|c|c|c|c|c|c|c|c|c|c|}
\hline Gage & 1 & 2 & 3 & 4 & 5 & 6 & 7 & 8 & 9 \\
\hline $\begin{array}{l}\text { Load } \\
\text { Stage }\end{array}$ & & & & train & $\frac{\text { in }}{\text { in }}$ & $0^{-6}$ & & & \\
\hline $\begin{array}{ll}1 & 1 \\
1 & 11 \\
1 & 1 i 1 \\
2 & i \\
2 & i i \\
2 & i i i \\
3 & 1 \\
3 & i i \\
3 & i 11 \\
4 & i \\
4 & i i \\
4 & \text { iii }\end{array}$ & $\begin{array}{l}-13 \\
-16 \\
-57 \\
-50 \\
-96 \\
-; 39 \\
-39 \\
-80 \\
-121 \\
-37 \\
-88 \\
-133\end{array}$ & $\begin{array}{l}-78 \\
-52 \\
-75 \\
-31 \\
-16 \\
-92 \\
-23 \\
-49 \\
-72 \\
-26 \\
-57 \\
-82\end{array}$ & $\begin{array}{l}-61 \\
-27 \\
-37 \\
-16 \\
-43 \\
-45 \\
-8 \\
-20 \\
-34 \\
-24 \\
-42 \\
-57\end{array}$ & $\begin{array}{r}-31 \\
-1 \\
-3 \\
-5 \\
-1 \\
-20 \\
1 \\
8 \\
0 \\
-12 \\
-14 \\
-20\end{array}$ & $\begin{array}{r}-40 \\
10 \\
16 \\
8 \\
13 \\
9 \\
7 \\
14 \\
25 \\
1 \\
4 \\
7\end{array}$ & $\begin{array}{l}-82 \\
-55 \\
-82 \\
-28 \\
-62 \\
-92 \\
-23 \\
-50 \\
-77 \\
-26 \\
-54 \\
-83\end{array}$ & $\begin{array}{l}-82 \\
-58 \\
-81 \\
-30 \\
-47 \\
-79 \\
-21 \\
-45 \\
-59 \\
-29 \\
-49 \\
-74\end{array}$ & $\begin{array}{l}-53 \\
-25 \\
-30 \\
-28 \\
-28 \\
-63 \\
0 \\
-12 \\
-25 \\
-15 \\
-25 \\
-42\end{array}$ & $\begin{array}{l}-28 \\
-49 \\
-65 \\
-31 \\
-57 \\
-79 \\
-16 \\
-42 \\
-60 \\
-20 \\
-45 \\
-64\end{array}$ \\
\hline
\end{tabular}


Table 18. Strain Data, 8'-0" Beam Spacing Static Test, Bottom Fast-West Gages on Section B-1

\begin{tabular}{|c|c|c|c|c|c|c|c|c|}
\hline Gage & 1 & 2 & 3 & 4 & 6 & 7 & 8 & 9 \\
\hline $\begin{array}{l}\text { Load } \\
\text { Stage }\end{array}$ & & & $S t t$ & & $10^{-6}$ & & & \\
\hline I 1 & 34 & 36 & 12 & -9 & 3 & -25 & 3 & 7 \\
\hline 1 is & 83 & Wh & 20 & -7 & 20 & -20 & 11 & 14 \\
\hline 1 1if & 131 & 47 & 31 & -9 & 47 & 6 & 20 & 31 \\
\hline $2 i$ & 43 & 27 & 12 & -3 & 25 & 27 & 17 & 24 \\
\hline 211 & 91 & 52 & 22 & -2 & 51 & 54 & 27 & 47 \\
\hline 2 iil & 134 & 79 & 38 & 6 & 74 & 81 & 46 & 59 \\
\hline 31 & 35 & 20 & 11 & -2 & 27 & 21 & 13 & 17 \\
\hline 311 & 76 & 45 & 22 & 2 & 45 & 47 & 23 & 35 \\
\hline 3111 & 127 & 68 & 28 & 1 & 66 & 71 & 31 & 52 \\
\hline 41 & 27 & 23 & 8 & -6 & -8 & 25 & 9 & 14 \\
\hline 4 is & 68 & 45 & 18 & -7 & 13 & 50 & 21 & 32 \\
\hline 4 iil & 109 & 67 & 27 & -8 & 38 & 73 & 35 & 51 \\
\hline
\end{tabular}


Table 19. Strain Data, 8'-0" Beam Spacing Static Test, Top NorthSouth Gages on Section 8-1

\begin{tabular}{|c|c|c|c|c|c|c|c|c|c|}
\hline Gage & 1 & 2 & 3 & 4 & 5 & 6 & 7 & 8 & 9 \\
\hline $\begin{array}{l}\text { Load } \\
\text { Stage }\end{array}$ & \multicolumn{9}{|c|}{ Strain $\left(\frac{\ln }{\text { in }} \times 10^{-6}\right)$} \\
\hline $1 i$ & -4 & -10 & -17 & -13 & -13 & -4 & -7 & 1 & 10 \\
\hline 1 is & $2 \overrightarrow{5}$ & 9 & 3 & -2 & -7 & $1 \overrightarrow{4}$ & 24 & 6 & 14 \\
\hline 1111 & 45 & 17 & 8 & -3 & -4 & 25 & 22 & 14 & 20 \\
\hline $2 i$ & 9 & 5 & 4 & -9 & $- 1 \longdiv { 4 }$ & 18 & II & -5 & 12 \\
\hline $2 i i$ & 24 & 10 & 7 & -7 & -21 & 21 & 22 & -2 & 15 \\
\hline 2111 & 36 & 13 & 13 & -7 & -21 & 29 & 25 & 2 & 21 \\
\hline $3 i$ & 14 & 5 & 5 & -5 & -15 & 10 & 9 & $1 \overline{4}$ & -3 \\
\hline 3 is & 28 & 11 & 9 & 0 & -17 & 31 & 14 & 13 & 1 \\
\hline $311 i$ & 43 & 20 & 15 & 2 & -12 & 29 & 28 & 17 & 31 \\
\hline $4 i$ & 8 & 5 & -1 & 0 & -13 & 9 & 16 & 6 & -7 \\
\hline $41 i$ & 21 & 7 & 1 & -2 & -23 & 17 & 22 & 2 & -6 \\
\hline 4 ili & 35 & 10 & 4 & 0 & -19 & 23 & 22 & 5 & -4 \\
\hline
\end{tabular}


157

Table 20. Strain Data, 8'-0" Beam Spacing Static Test, Bottom NortinSouth Gases on Section 8-1

\begin{tabular}{lllllllll}
\hline Gage & 1 & 2 & 3 & 4 & 6 & 7 & 8 & 9 \\
\hline
\end{tabular}

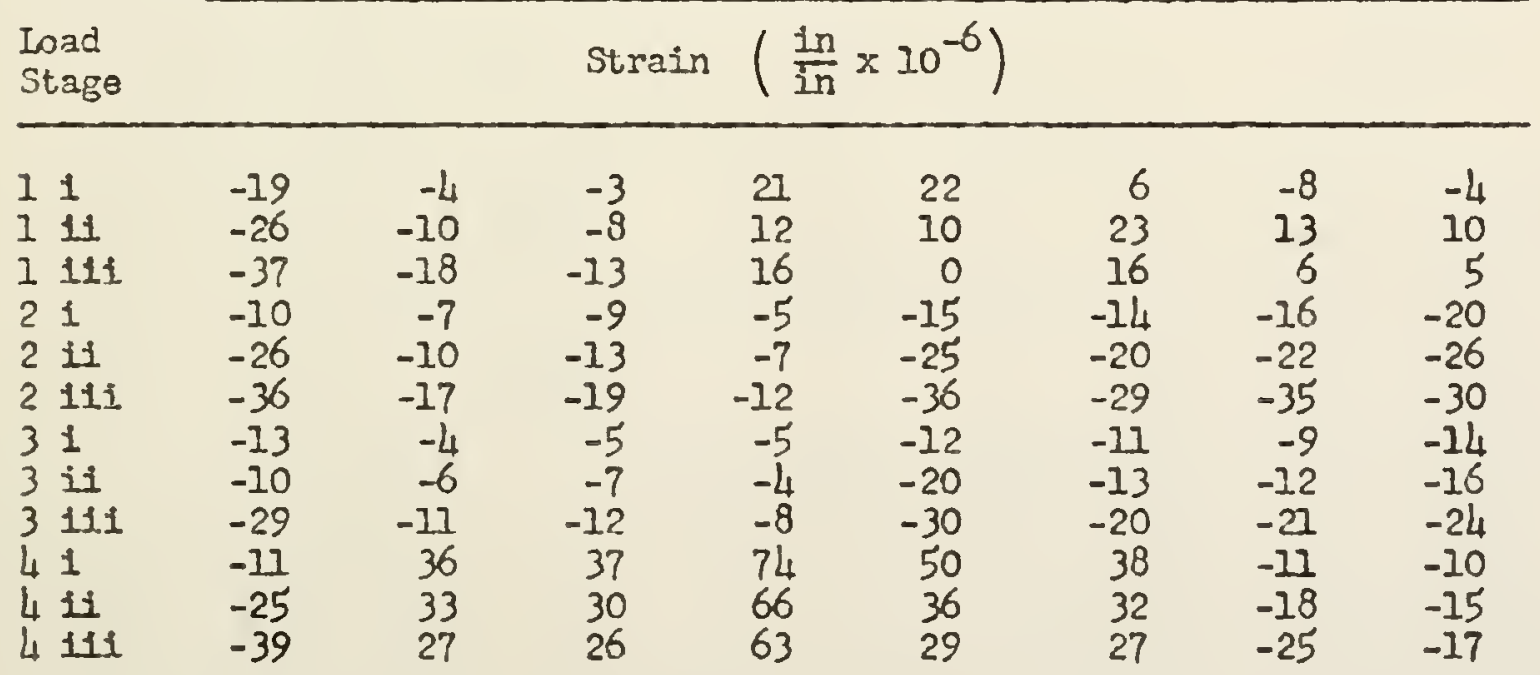




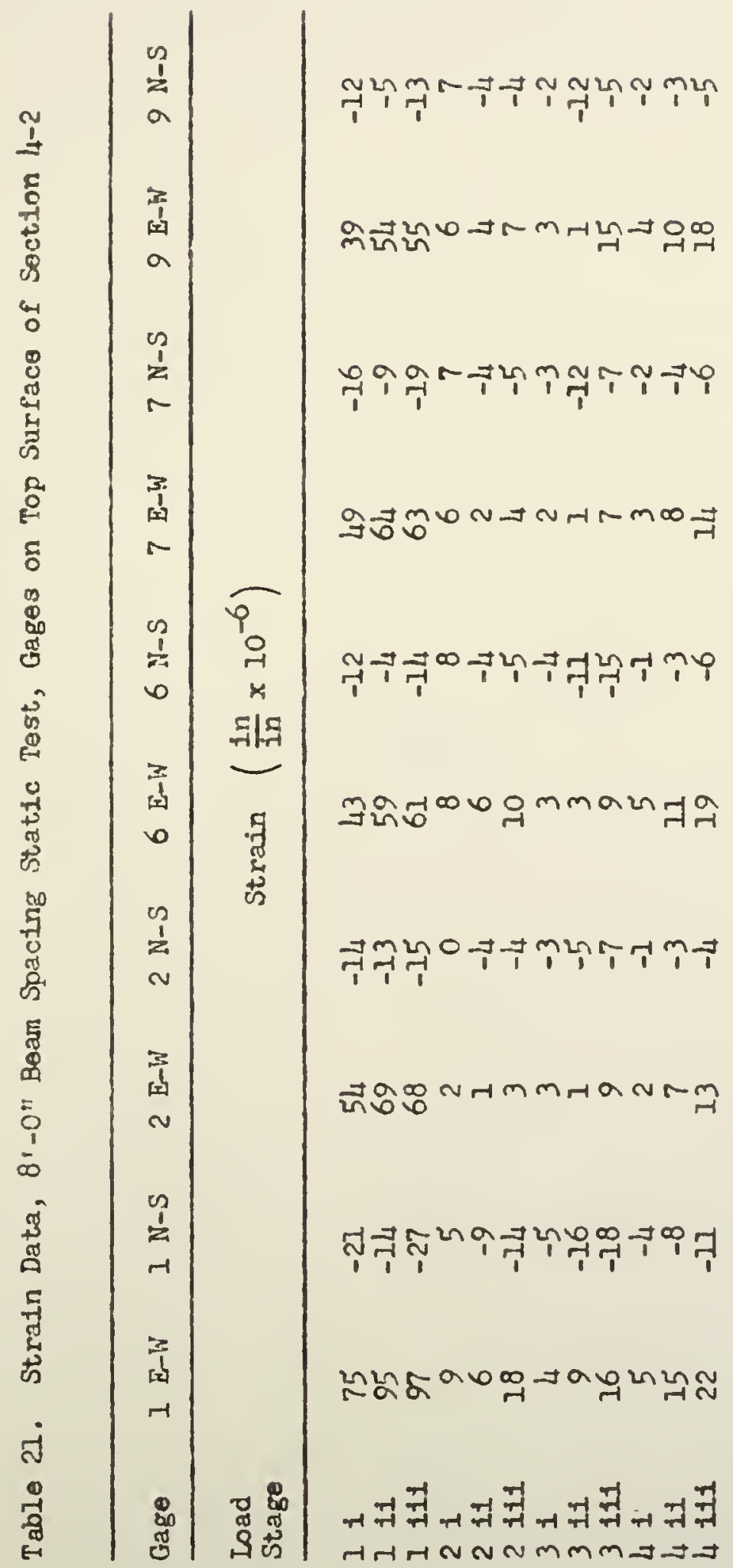


APPENDIX C 


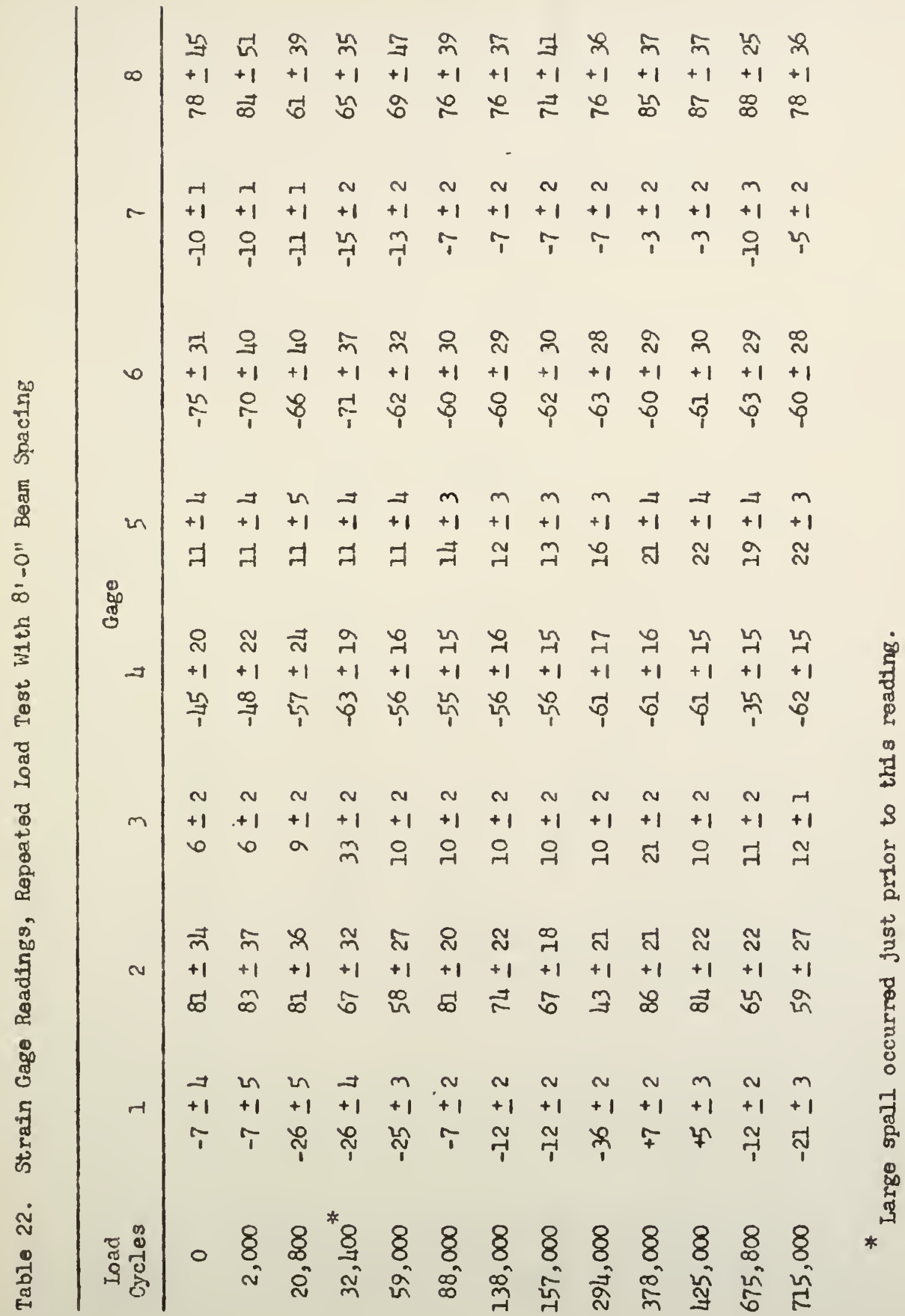




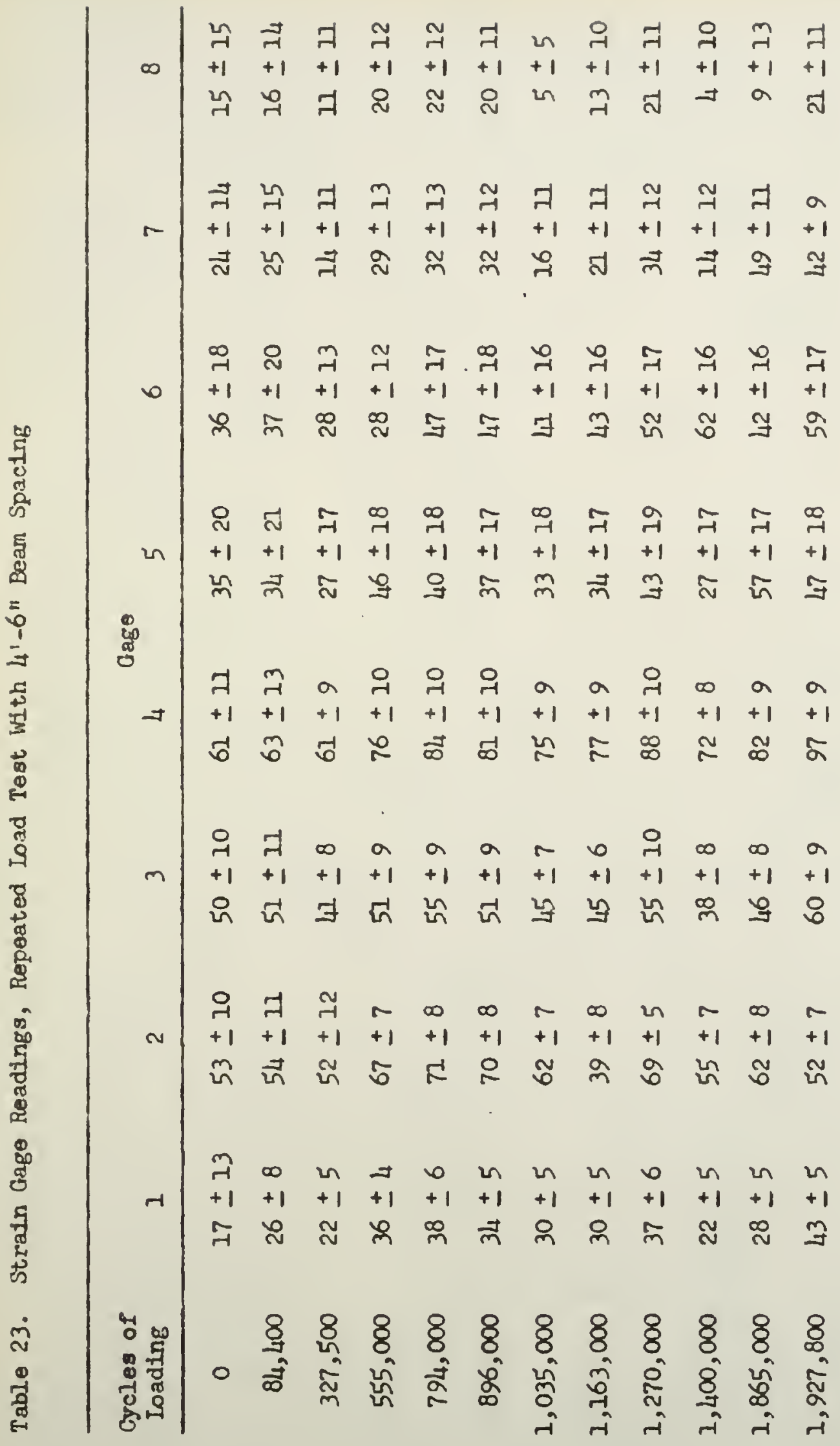



